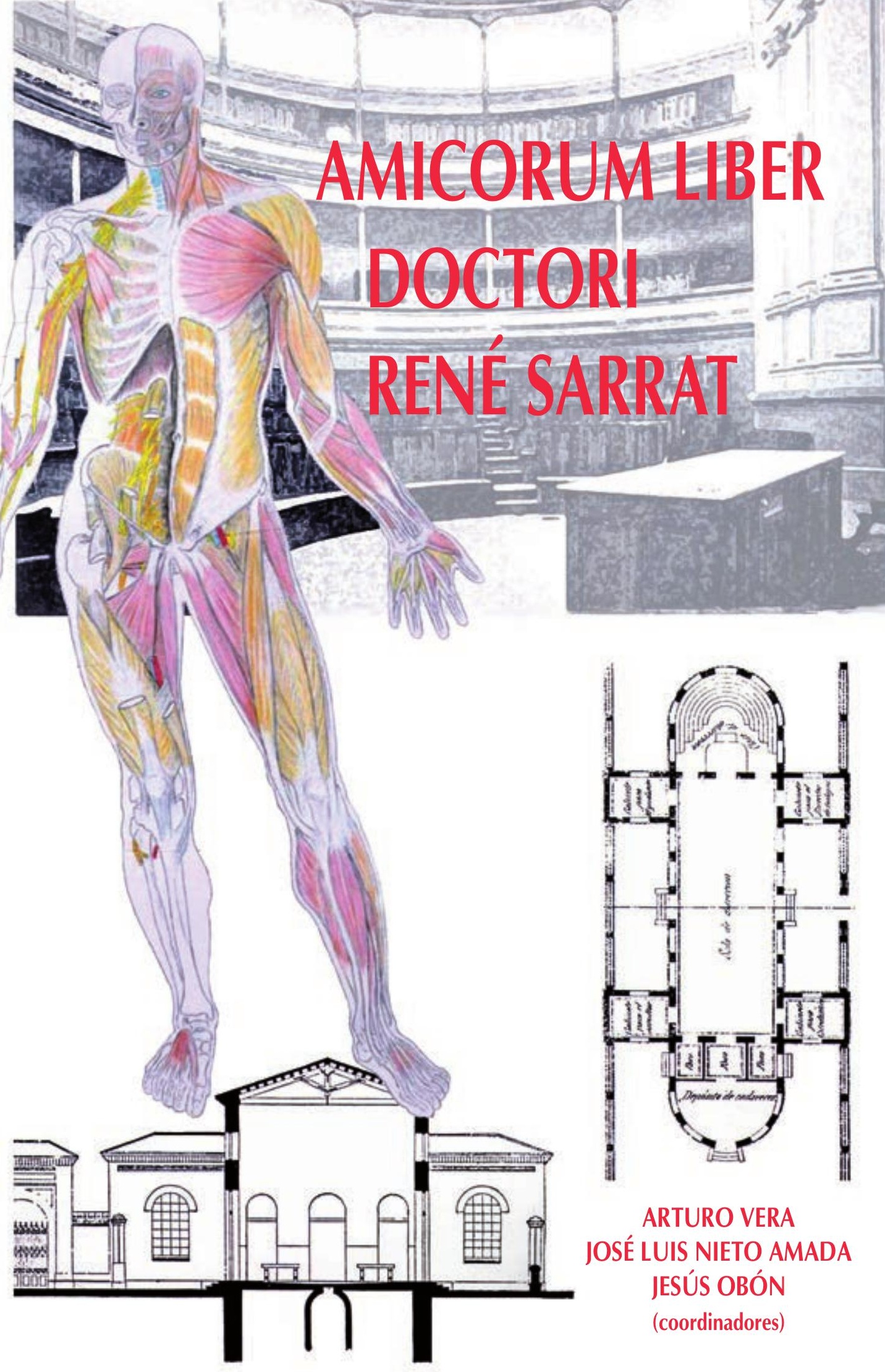



AMICORUM LIBER DOCTORI RENÉ SARRAT 



\title{
AMICORUM LIBER DOCTORI RENÉ SARRAT
}

\author{
ARTURO VERA \\ JOSÉ LUIS NIETO AMADA \\ JESÚS OBÓN \\ (coordinadores)
}

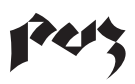

Prensas Universitarias de Zaragoza 
AMICORUM liber doctori René Sarrat / Arturo Vera, José Luis Nieto Amada, Jesús Obón (coordinadores). - Zaragoza : Prensas Universitarias de Zaragoza, 2009

162 p. : il. ; $23 \mathrm{~cm}$

DL Z-1124-2009 — ISBN 978-84-92521-91-3

Sarrat Torreguitart, René-Homenajes

SARRAT TORREGUITART, René (1937-)

61Sarrat Torreguitart, René(082.2)

929Sarrat Torreguitart, René

Cualquier forma de reproducción, distribución, comunicación pública o transformación de esta obra solo puede ser realizada con la autorización de sus titulares, salvo excepción prevista por la ley. Diríjase a CEDRO (Centro Español de Derechos Reprográficos, www.cedro.org) si necesita fotocopiar o escanear algún fragmento de esta obra.

(C) Los autores

(C) De la presente edición, Prensas Universitarias de Zaragoza

1. edición, 2009

Diseño de cubierta: José María Smith Ágreda y Víctor Smith Fernández

Edita: Prensas Universitarias de Zaragoza. Edificio de Ciencias Geológicas, c/ Pedro Cerbuna, 12 50009 Zaragoza, España. Tel.: 976761 330. Fax: 976761063

puz@unizar.es http://puz.unizar.es

Prensas Universitarias de Zaragoza es la editorial de la Universidad de Zaragoza, que edita e imprime libros desde su fundación en 1542.

\section{Impreso en España}

Depósito Legal: Z-1124-2009

Impresión: Servicio de Publicaciones. Universidad de Zaragoza 


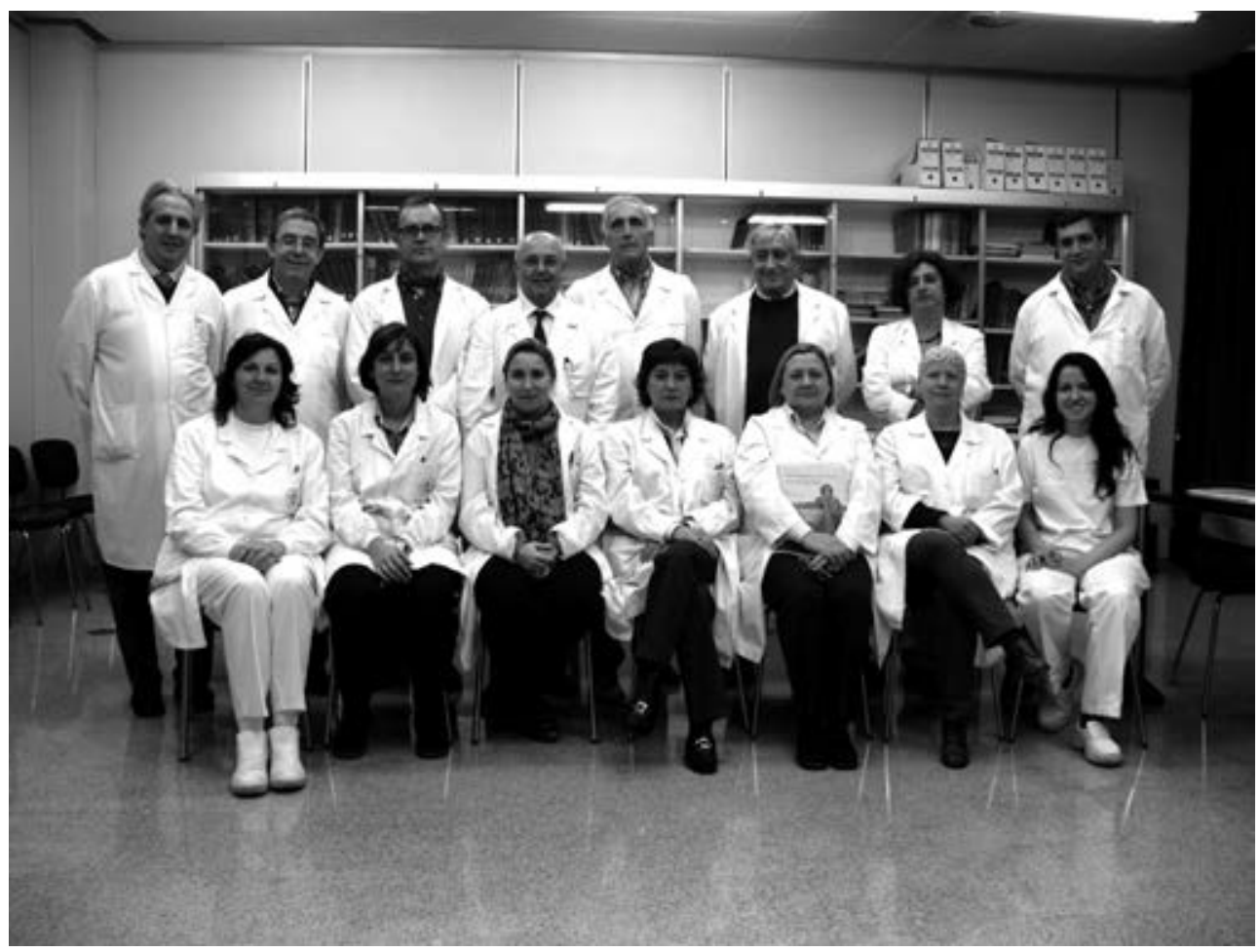

Profesores de Anatomía. Curso 2008-09.

Primera fila: Susana (Téc. Lab.), Pilar (Téc. Lab.), A. Cisneros, J. Blasco,

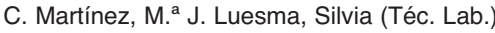

Segunda fila: J. Obón, J. Whyte, J. D. Escolar, A. Vera (Decano Facultad), René,

J. L. Nieto (Dr. Dpto.), M. J. Barral, M. Lahoz 



\section{OFRECIMIENTO}

Es nuestra intención ofrecer este Amicorum liber al doctor René Sarrat Torreguitart, catedrático ya jubilado, del Departamento de Anatomía e Histología Humanas, de la Universidad de Zaragoza. Criado en Gimenells, en plena comarca del Segriá, tan cerca de nuestras tierras del Aragón oriental, el doctor Sarrat estudió, primero, en los Maristas de Lérida y, luego, en nuestra Facultad de Medicina, al lado de don José Escolar, maestro y cabeza de la más fructífera escuela española de Anatomía del siglo pasado, siendo catedrático de la Facultad de Medicina de Zaragoza, después de haberlo sido de las de Bilbao y del Colegio Universitario de Las Palmas de Gran Canaria y miembro numerario de las Reales Academias de Medicina de Bilbao y Zaragoza.

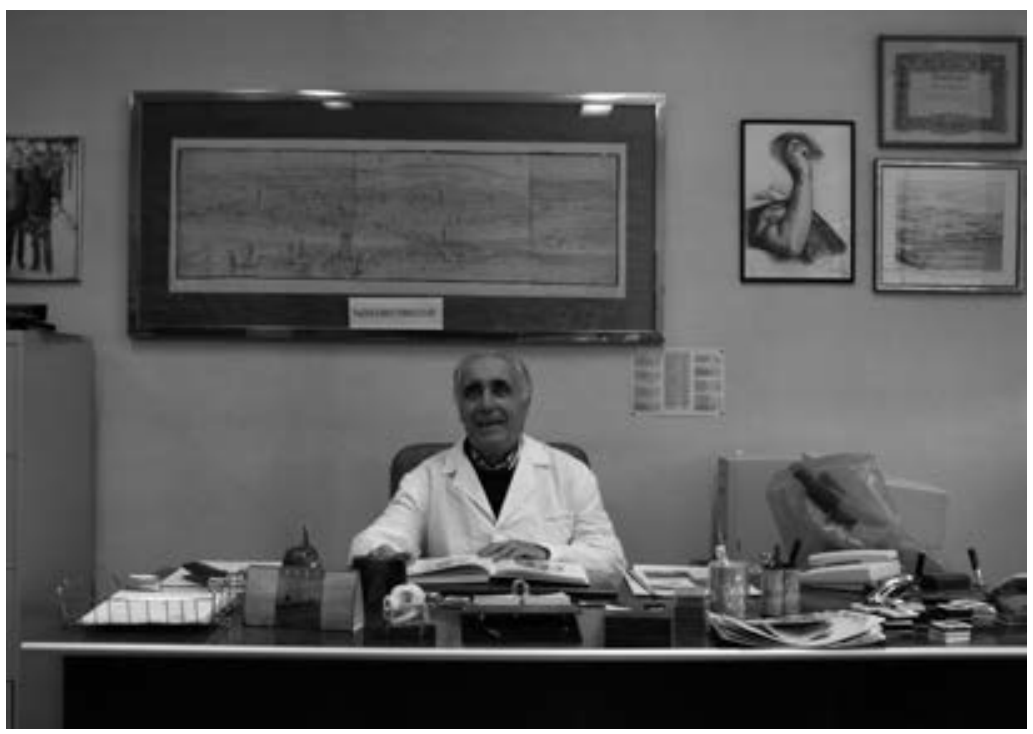


Llegada la jubilación, el doctor René Sarrat ha huido de los homenajes y ceremonias que acompañan a estas despedidas y solo ha acudido a recibir la Medalla de plata con que nuestra Facultad de Medicina distingue a quienes cierran su vida académica en este Centro. Por ello, los profesores del Departamento de Anatomía e Histología Humanas de Zaragoza, quisimos plasmar nuestro recuerdo en este Amicorum liber, en el que han participado, además, muchos de aquellos que con él han sido parte de la Escuela anatómica de don José Escolar, junto a otros que, compartiendo también el magisterio del doctor Escolar, optaron al final por otras disciplinas médicas, y como no, los discípulos y amigos que el profesor Sarrat ha ido dejando en los sitios donde ejerció su magisterio. Entre todos, nos han dejado unas semblanzas que rebosan admiración y respeto y que vienen a compendiar no solo la vida y la obra del doctor Sarrat, sino que aportan también testimonios inestimables de la Anatomía española del siglo pasado.

En todo libro de homenaje, siempre ocurre que alguien encuentra la falta de algunos testimonios personales que hubieran enriquecido aún más la obra. Lo mismo sucederá en este caso. Como coordinadores somos responsables de ello. Lo que sí afirmamos es que no hubo ninguna negativa a participar en estas páginas, a pesar de las difíciles situaciones familiares o personales de algunos de los invitados. Algo que, como coordinadores, valoramos de manera muy especial y que justifica el título de amicorum que, desde el principio, quisimos dar a este libro.

Antes de cerrar este ofrecimiento al doctor René Sarrat, los editores de este Amicorum liber, entre los que incluimos con justicia a nuestro compañero Jesús Obón, debemos agradecer al Colegio de Médicos de Zaragoza, del que el doctor René Sarrat fue vicepresidente, a la Facultad de Medicina de Zaragoza y a los miembros del Departamento de Anatomía e Histología Humanas de esta vieja Universidad Caesaragustana, la ayuda prestada para sacar adelante este Amicorum liber y, de una manera muy especial, a cuantos amigos del doctor René Sarrat han aceptado nuestra propuesta de colaboración para esta obra.

Querido René, abandonas la Facultad y el Departamento en los que has ejercido con brillantez y lealtad la docencia anatómica, pero como responsables actuales de los mismos, queremos decirte que sus puertas estarán siempre abiertas para ti. Un abrazo de todos nosotros.

Arturo Vera Gil

Decano de la Facultad de Medicina
José L. NiETO AMADA

Director Dpto. Anatomía e Histología Humanas 


\title{
AL PROFESOR RENÉ SARRAT TORREGUITART
}

\author{
ARturo Vera GIL \\ Catedrático de Anatomía Humana y Decano de la facultad de Medicina de Zaragoza \\ Carmen Pérez Castejón \\ Catedrática de Histología Humana de la Facultad de Medicina de Zaragoza
}

Profesor René Sarrat

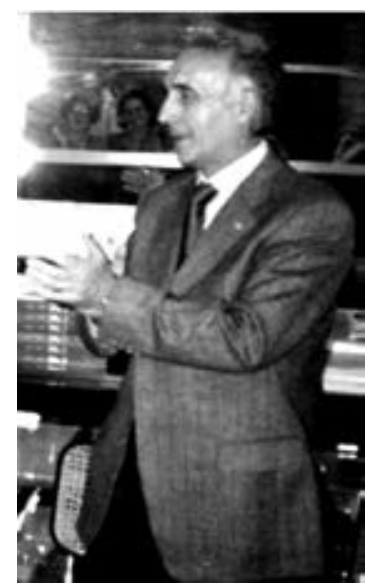

Es ahora frecuente que, al celebrar la jubilación, los amigos y compañeros del «alegrado» - traducción literal del latín— le dediquen unas palabras escritas que se acopian en un «amicorum liber».

Esta hora nos llega a todos, antes o después, y malo es que no nos llegue, eso indica que no hemos ocupado un lugar en esta vida durante el tiempo necesario y, por esa razón, en lugar de «amicorum liber» nos dedican una necrológica y un epitafio lapidario.

Afortunadamente, estamos ante el primero de los supuestos y, por ello, nos enfrentamos ante la hoja, ya no del todo blanca, y dirimimos cómo acabar de ennegrecerla parcialmente.

Primero, es preciso tomar una serie de decisiones:

Cómo lo escribo... ¿En calidad de Decano? ¿De compañero? ¿De «hermano menor» de la misma «familia científica» o Escuela?

Todos descartados.

Lo haré como testigo cercano de 48 años de su vida.

Segunda elección fundamental: ¿ ¿Solo o en compañía?

Está claro que en compañía de otro testigo, de solo 46 años de la vida de René, pero de la que, desde entonces, no me he separado, más bien todo lo he compartido. 


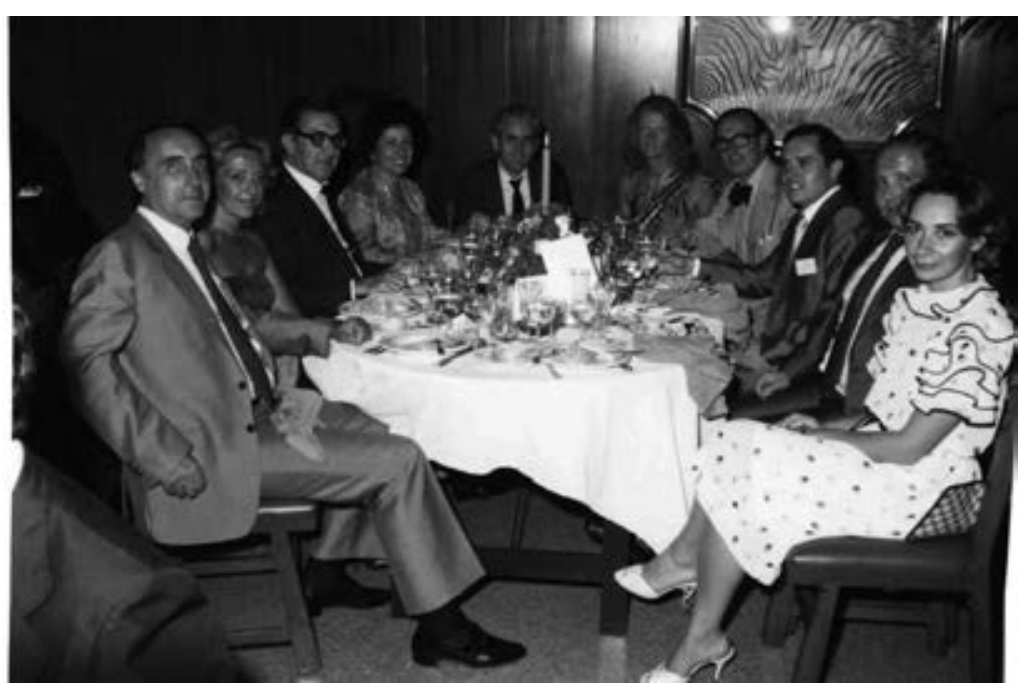

René, Ana Torres, Pedro Amat y Sra. Ricardo Vázquez, invitados extranjeros, Pastor, Arturo Vera y Carmen Pérez

Por eso, Carmen y yo queremos pasar una breve pero larga mirada sobre ese tiempo en que te hemos conocido y lo haremos con una cita previa.

Sabes muy bien, René, que en mi despacho de la Facultad, conservo el cartel del anuncio de la última lección magistral de Anatomía Humana de nuestro común amigo, José María Smith Ágreda.

En dicho cartel, manuscrito y firmado de su puño y letra, ese recio aragonés me espeta:

«Lo que eres fui, lo que soy serás...».

Frase lapidaria donde las haya y cierta como la vida misma.

Por eso, y revestidos de la humildad que da la certeza de esa frase, comenzamos el recuerdo de tanto tiempo, con el candor de los niños que, matriculados en primero de Anatomía, deslumbrados por la Facultad e impresionados por la eficacia de la Anatomía de don José (¿Hace falta que especifique Escolar García?... para nosotros don José solo hubo uno) un buen día de primavera, en la Semana Santa de 1965, siendo un jefecillo de mesa que se había prestado voluntario durante las vacaciones para limpiar y tratar las calaveras, procedentes de una «razzia» por alguna fosa común, se tropezó con un individuo alto, moreno y desenvuelto que, en vez de la distancia y prosopopeya que orlaba la relación de los profesores hacia los alumnos, se me dirigió y con toda la naturalidad me dijo: «Hola, soy René Sarrat». 
Después vino lo demás, acababa de volver de Alemania y no estaba nada feliz de tener que hacer, a aquellas alturas, una «reconstrucción tridimensional en plástico espumoso", me parece recordar que de un corazón, cuando, ya ducho en técnicas de investigación punteras, don José le había ordenado una tarea de principiante.

Carmen y yo recordamos la entrañable amistad que tenía con otro torbellino de la naturaleza. Pedro Mestres. También catalán y extrovertido.

El tercero en concordia en aquella época, ni era catalán ni era extrovertido, pienso que era todo lo contrario, era Miguel Lafarga.

Ese era el equipo genuino de René, más tarde estuve yo cuando compartí Internado Pensionado con Miguel Lafarga y, por un momento, sobrevoló el traslado a la Autónoma de Madrid de don José que, en principio, arrastraría también a René, pero, habiendo sacado la Cátedra ya, José María Smith y habiéndose pensado que, por unas u otras causas, en Zaragoza quedaría el siguiente equipo; René por la madurez (ya era segundo de a bordo), Pedro se iba a Alemania y, Lafarga y yo, no habíamos terminado la carrera todavía.

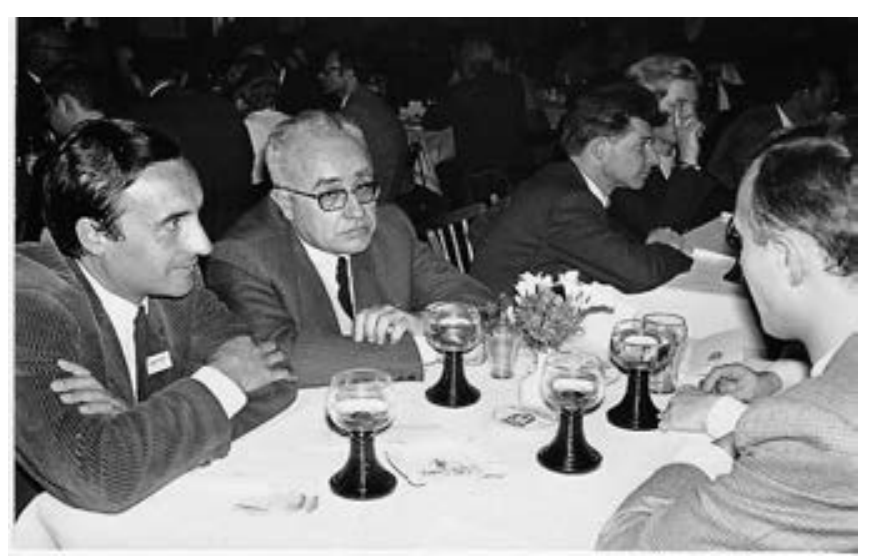

René Sarrat junto a don José Escolar

Creo recordar que fue un poco antes de todo esto, cuando se «aceleró cierto deterioro en la sala de disección» que condujo a unas necesarias obras de modernización.

Si René, me refiero a las hipótesis de la «Monja fumadora» y otras aventuras de aquel entonces...

Luego, las cosas evolucionaron de otra manera distinta, Pedro se largó de Anatomía y organizó su vida en la Histología Alemana, llegando a los más altos niveles docentes y académicos. Lafarga también se fue recién acabada la carrera, a la Histología, pero Española y es hoy catedrático de Histología en la Universidad de Santander y, en la escuela de don José, pasó lo nunca visto hasta entonces. Tres «deserciones consecutivas» (la precedente es la de Juan Saldaña) que ocasionaron un vacío generacional. 
Y allí me encontré yo, detrás de Santiago Rodríguez que, de la misma época que René, ya había regresado de Alemania.

Por ello, en calidad de ayudante recién escudillado, fui de «maletero, proyector y chico de los recados» esto es, de escudero, acompañando a René, «para aprender» por orden de don José, en sus oposiciones a la Cátedra de Bilbao, que ganó brillantísimamente.

Pero, en paralelo, contemplamos otras circunstancias vitales de René en aquella época.

$\mathrm{Su}$ «acongojo» cuando, buscando a alguien que le pudiese acercar a Fraga para recoger su flamante Peugeot recién reparado, no encontró otro disponible que yo, joven e inexperto, justamente salido de un serio accidente en que deshice mi primer $600 \mathrm{y}$ estrenando mi 850 (ambos modelos pequeñitos de SEAT, para ilustración de los jóvenes que no vivieron aquella época).

Su enorme éxito con las mujeres, que le encontraban cierto parecido con el actor Christopher Lee, el famoso intérprete del Conde Drácula.

Le conocimos alguna que otra novia y le precedía una larga leyenda... Pero al final, se llevó el gato al agua alguien que había entrado a trabajar como laborante del CSIC, en el departamento de Anatomía, a la vez que yo comenzaba la carrera, Ana Torres.

Cuando, ya catedrático de Bilbao, nos anunciaron su cuidadosamente guardado secreto, fue un bombazo. El regalo de boda hubo de ser por doble partida, por cierto que en eso salí ganando, pues el tomavistas súper 8 lo supongo, años ha, desaparecido, sin embargo, el proyector de diapositivas Cabin que el matrimonio SarratTorres nos regaló al matrimonio Vera-Pérez por motivo de nuestra boda, nos acompañó en casi todas nuestras oposiciones y todavía está operativo, en casa de mis padres.

Luego, René fue testigo desde el tribunal, o como observador cualificado, de mi defensa de Tesis Doctoral, de mi consecución de la Adjuntía de cuerpo de Zaragoza y de la Agregaduría de Valencia. De mis intentos por reunirme con él en Bilbao, solo que él se iba a Las Palmas, y finalmente de nuestra común llegada, como catedráticos, a la Facultad de Medicina de Zaragoza, al comienzo del curso 1984-85.

Desde entonces, mucha agua ha corrido por el Ebro y muchos años de compañeros y compañeras de Departamento, pues tanto Ana como Carmen se incorporaron al mismo Departamento, en virtud de la LOU y la modificación de las áreas de conocimiento, que desgajaron a la Histología de la Anatomía Patológica, lo que las condujo al actual Departamento de Anatomía e Histología, antes llamado de Ciencias Morfológicas.

De este montón de años, mucho y poco que decir, creo que es mejor aplicar aquello de la medicina basada en la evidencia.

Solo presentaré una evidencia, después de tantos años, en los que ha habido de todo, como suele suceder entre quienes conviven, seguimos siendo amigos... 
En el próximo día de San Lucas, Dios mediante, tendré el placer y el honor de imponerte la medalla de la Facultad que, en reconocimiento a tu generosa y larga trayectoria de servicio a la Universidad y, en particular, a esta Facultad de Medicina, la Junta de la misma decidió, por unanimidad, concederte.

Siempre tuyos, Carmen Pérez Castejón y Arturo Vera Gil.

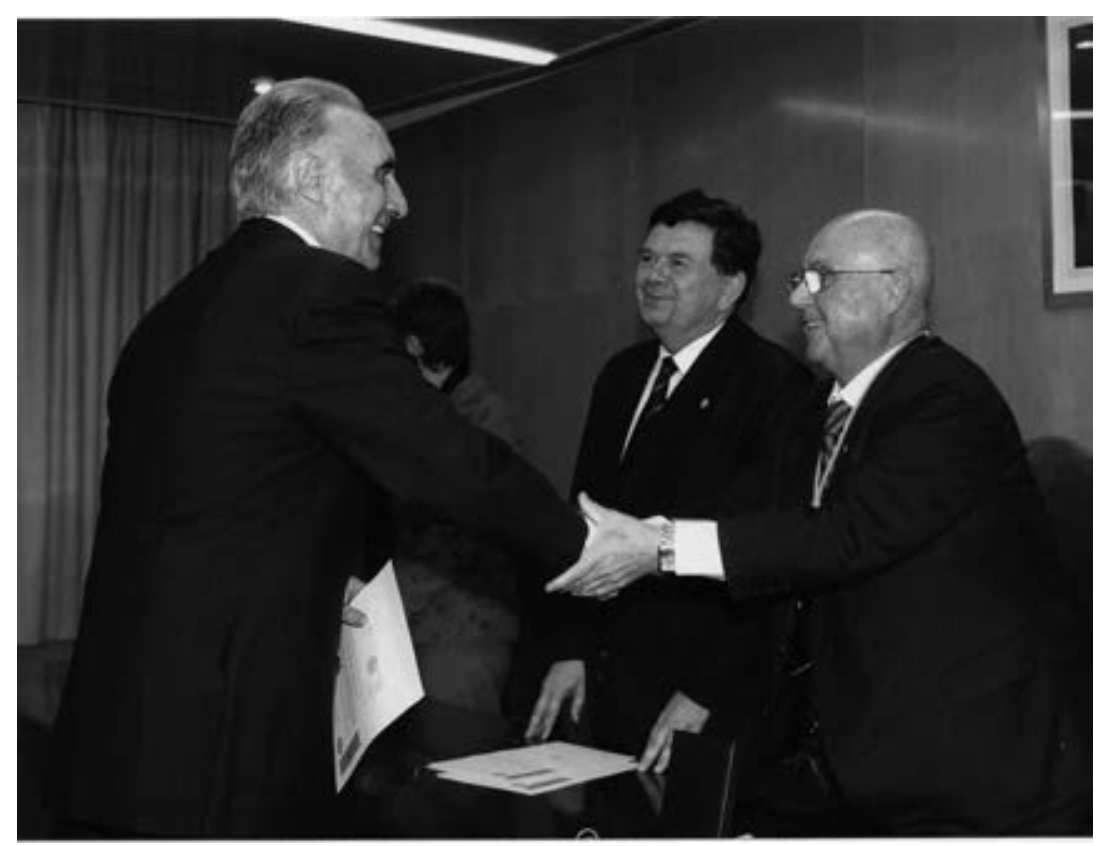

Acto de entrega de la Medalla de la Facultad de Medicina René Sarrat junto a Manuel López, Rector de la Universidad de Zaragoza, y Arturo Vera, Decano de la Facultad de Medicina. 


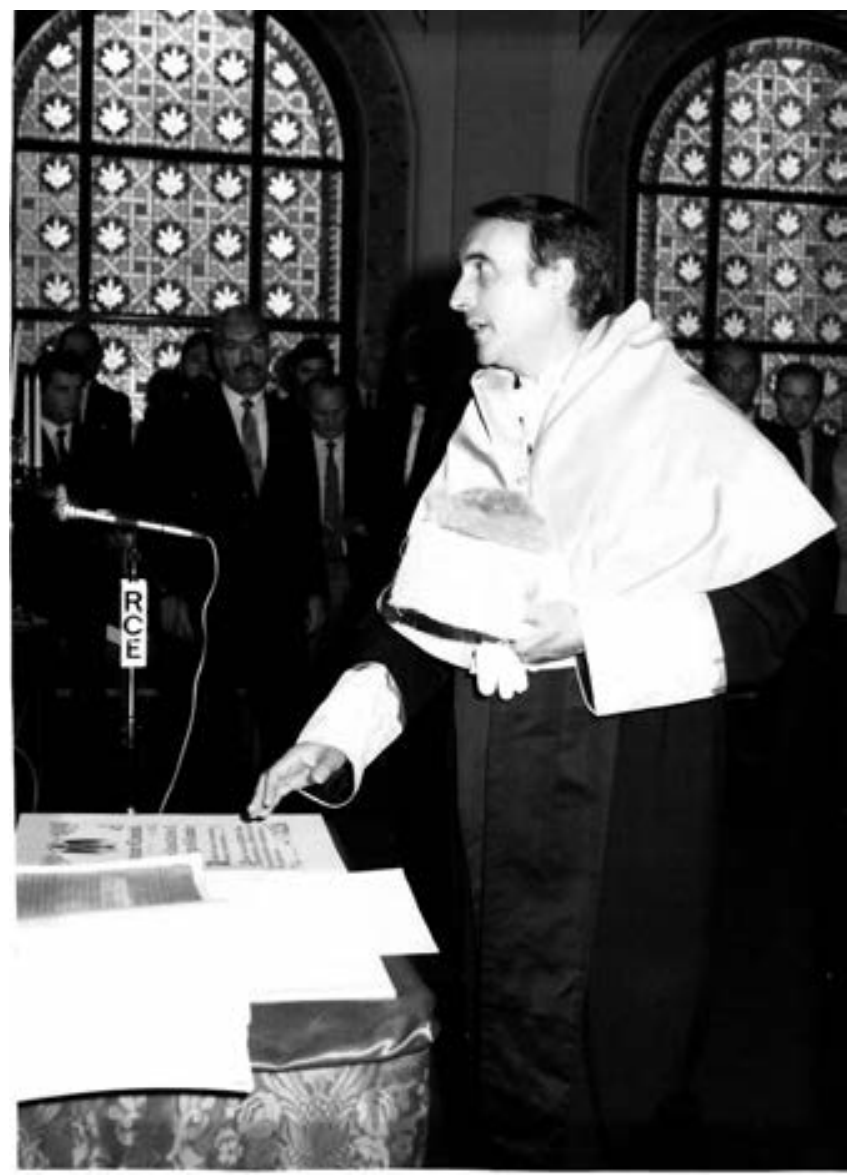




\title{
APUNTES DE UNA VIDA
}

\author{
RAFAel MAZO TORRES \\ Director del Hospital Clínico Veterinario de la Universidad CEU-Cardenal Herrera de Valencia \\ JAVIER MAZO TORRES \\ Ingeniero Superior Industrial. Gerente y Responsable de Marketing \\ JUAN JOSÉ MAZO TORRES
}

Profesor Titular de Física de la Materia Condensada. Facultad de Ciencias. Universidad de Zaragoza

Gimenells. René nació en Corvins, un pueblecito de la provincia de Lérida, muy cercano a Aragón. Era 1937, plena Guerra Civil. Podríamos decir que aquí comienza una historia. Una historia que muchos hemos parcialmente compartido y así seguimos y seguiremos haciéndolo. Hemos dicho que René nació en Corvins, sí, pero su pueblo es Gimenells. Allí es donde vivió de pequeño, allí es donde forjó su carácter y allí sigue acudiendo con frecuencia a pasear por sus calles, recibir la fragancia de sus flores, a recorrer sus campos y llenar sus pulmones de vida, de verdadera vida. Para quien no haya estado allí podemos decir que Gimenells se encuentra en un llano, rodeado de

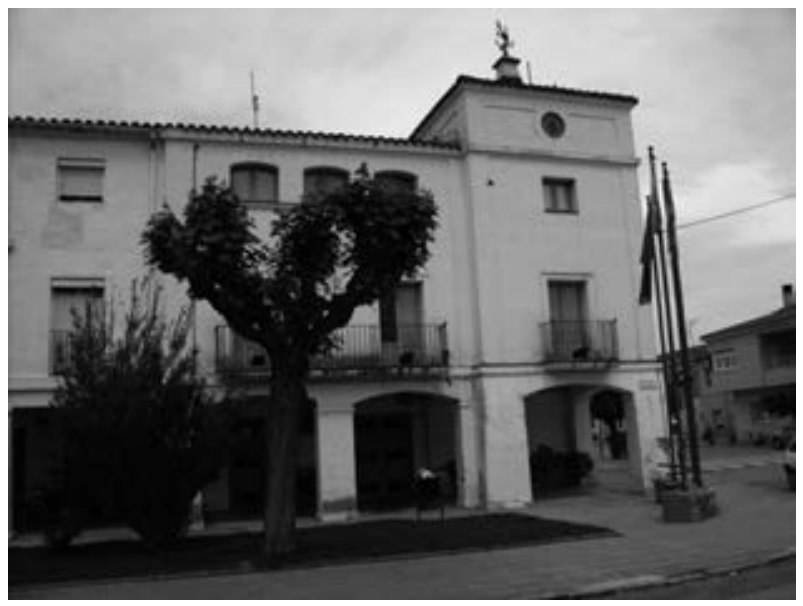

Ayuntamiento de Gimenells

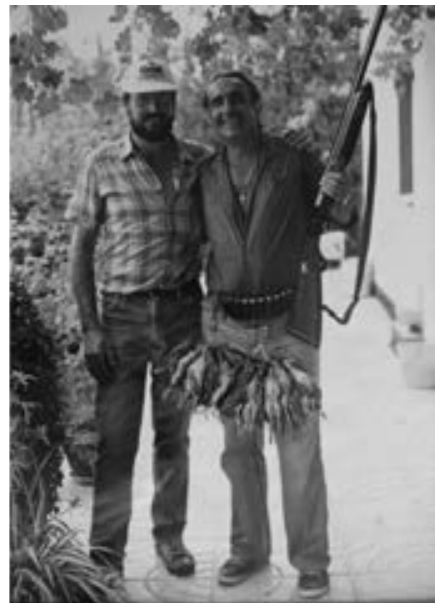

René con su amigo Miguel 
campos de cultivo, de fincas y de torres. Gimenells es su pueblo y allí está su calle. Hace ya muchos años que sus vecinos le dedicaron una calle. Gimenells es su casa. Gimenells es la torre con sus cerezos, entre sonrientes girasoles y generosos viñedos. Gimenells es la caza, aún recordamos con emoción ese primer día que, aún siendo niños, salimos a acompañarle. Nos levantamos al alba con el corazón exaltado, recorrimos campos de alfalfa y montes de tomillo y volvimos con tres pobres conejos. Nuestras medallas. Allí René se transforma y vuelve a sus raíces. Se hace hombre de campo y anfitrión inmejorable que nos abre su casa, cocina para nosotros la mejor carne a la brasa, chorizos y longanizas y nos ofrece sabrosas frutas. Ahora Gimenells se convierte en sitio de retiro y descanso, con la compañía de Ana, de Neli, del querido Anselmo y de muchos más. No obstante, mantente alerta y no te descuides, tus sobrinos y sobrino-nietos siempre amenazaremos con perturbar esa paz. Hace ya mucho tiempo que sabemos que tu casa también es nuestra. Aún nos quedan muchos caminos por recorrer, a pie o a golpe de pedal, muchos paisajes por admirar y muchos panes por compartir.

Medicina. René iba para letras. A él le gustaba escribir y le gustaba la filosofía. Sí, René iba para letras. Pero un día su padre con cierto gesto de contrariedad le dijo algo así: «...vaya, yo que siempre había tenido la ilusión de tener un hijo médico...». Y ese día nació un médico. Un médico que además escribe muy bien, como todos sabemos. Dejó su pueblo, vino a Zaragoza, se instaló en el Cerbuna y se aplicó a ello. Vaya si se aplicó. René es un médico fantástico. Sabe de todo, todo lo relaciona y siempre acierta. En la familia la primera opinión siempre es la suya. Luego viene el especialista, un mero trámite para confirmar el diagnóstico de nuestro tío y afinar el tratamiento. Pero si eso está bien, muy por encima está su exquisito trato con el paciente y su familia, su delicadeza y cariño. Siempre sabe encontrar la palabra adecuada y el gesto preciso. Su sola presencia ya tranquiliza y sana. Para él todos los enfermos son iguales y se merecen el mismo trato y dedicación. El infinito. Quizás por ello participó siempre tan activamente en las reuniones de la Real Academia de Medicina de Zaragoza y presidió durante años la Comisión Deontológica del Colegio Oficial de Médicos de Zaragoza. Siempre le preocuparon los aspectos legales y éticos de la práctica médica y se comprometió con el seguimiento de esa máxima que sitúa a la Medicina al servicio del hombre y, por lo tanto, le obliga a respetar la vida humana y la dignidad de la persona desde su comienzo hasta su final.

Universidad. René es universidad. Su vinculación y compromiso con ella ha sido constante y ha cubierto las más variadas facetas. Fue estudiante ejemplar en tiempos mozos. Ha sido decano, director de departamento, miembro de mil comisiones y muchas otras cosas a lo largo de los años. Decíamos que René se instaló en «El Cerbuna» y allí comenzó su amor por la universidad. ¡Cuántas veces le hemos oído hablar de aquella época con la mayor de las ilusiones! Siempre recordará a sus excelentes compañeros, la vida de Colegio, las clases en la antigua Facultad de Medicina y Ciencias. Y así pasaban los años, entre inviernos de estudio y veranos de trabajo en el campo, y se fue forjando un médico. Un médico que pronto aprendió a gozar con la 
investigación. René se encontró con don José Escolar y de su mano su vida giró hacia la anatomía y se hizo hermano de Pedro Amat y de Víctor y José María Smith, entre otros, todos miembros de una misma Escuela que ya ha formado a cientos de doctores. Su labor investigadora le llevó a trabajar a Alemania con los mejores. Fueron tiempos difíciles los de Alemania, su padre acababa de fallecer prematuramente lo que dejó a su familia en una posición comprometida. Allí sufrió, ahorró, trabajó y aprendió. Pero por encima de todo René es profesor, un magnífico profesor. Como si fuera un director de orquesta, consigue que sus alumnos sigan su actuación con atención máxima día tras día. El aula abarrotada está pendiente de él. Utiliza todo su cuerpo para comunicar, administra las pausas precisas, incluye bromas de la manera adecuada, transmite los conceptos con claridad y eficacia, los dibujos son exactos y la disección perfecta. Y es que no se puede enseñar sin hacer nacer en el otro el deseo de aprender. ¡Qué fácil decir y qué difícil de hacer! René hubiera sido un magnífico profesor de lo que hubiera querido, pero eligió la Anatomía. Sus clases son recordadas por generaciones de médicos que estudiaron en Bilbao, Las Palmas o Zaragoza. En todos estos sitios ha dejado una profunda huella de la que hablarán otros en este libro. La universidad le debe mucho a René. Su entrega a ella ha sido generosa, al ciento por ciento y desde el primer momento. ;Gaudeamus igitur!

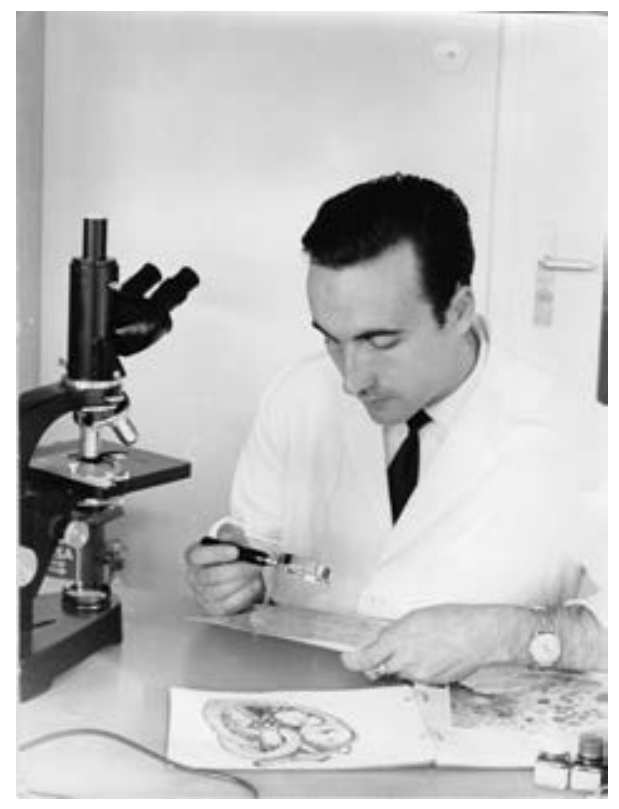

Su dedicación al laboratorio 
Familia. Si el trabajo es una de sus pasiones, su familia es la otra. Nosotros hemos tenido la suerte de tenerlo cerca desde pequeños. Uno de nuestros recuerdos más tempranos corresponde a una batalla salvaje librada en el suelo del salón de nuestra primera casa donde tres pequeños ratones, tres hermanos, luchábamos contra un león enfurecido, nuestro tío René. Con René hemos compartido comida domingo tras domingo y con él hemos visto los mejores partidos (es del Barça, su mayor defecto).

Durante años nos hemos empapado de sus anécdotas e historias de sus tiempos de joven estudiante, sus primeras urgencias en el hospital clínico de Zaragoza, su experiencia en Alemania, sus investigaciones, las clases, los alumnos, las conferencias... siempre relatadas con ilusión y vocación de servicio a los demás. Seguramente fue él quien sembró en nosotros la semilla de una vocación universitaria. Le tenemos mucho que agradecer. Con René cantamos jotas y villancicos en familia, y canciones de tuna. Entonces él explota su especialidad, una preciosa segunda voz, con un tono muy personal. A su lado parece que los demás cantamos bien, jjá! Y con René en casa también hemos aprendido muchas otras cosas. Lo primero a querer a nuestros mayores, como le vimos querer a su madre, "padrina» para sus hijos y para nosotros, y como también le vimos querer y cuidar a nuestros queridos y añorados abuelos Pepe y Concha. Y aquí es de justicia hablar de Ana. Porque en verdad, quizás no todos lo sepáis, René, desde hace mucho tiempo, no es René. Es René y Ana. Ana es su consejo, su bastón, su compañía. Y es que ellos se saben prácticamente de memoria la Carta de San Pablo a los Corintios:

Aunque yo hablara todas las lenguas de los hombres y de los ángeles, si no tengo amor, soy como una campana que resuena o un platillo que retiñe... El amor todo lo disculpa, todo lo cree, todo lo espera, todo lo soporta. El amor no pasará jamás.

Y así es su vida.

Maestro. La verdad es que ya hemos dedicado algunas frases a resaltar este aspecto de la vida de René. René ha sido y es un maestro para los que lo tenemos cerca. Algunos lo han conocido en el aula, impartiendo sus lecciones de anatomía. Con él han aprendido a conocer al detalle el cuerpo humano. Pero también han aprendido otras cosas, por ejemplo, el amor por el trabajo bien realizado, dedicación, constancia y entrega. Nos ha enseñado su compromiso moral, un pacto no escrito con sus alumnos. Ese pacto no es entre iguales, y por eso a él le obliga más y de ese pacto surge el respeto y cariño con el que siempre le hemos oído hablar de sus alumnos. Y también por eso se sabe sus nombres y apellidos y siempre ha buscado estimularlos y apoyarlos encontrando lo mejor de cada uno. René ha sido un maestro para sus discípulos y tesinandos. Y es que ha dirigido más de 70 tesis doctorales, a lo largo de su carrera. René también ha sido un maestro en temas de ética y deontología profesional para muchos de sus compañeros médicos a quienes se ha acercado siempre con ánimo de ayudar y acompañar, aportando a quien quisiera escuchar una visión distinta, basada en prime- 
ros principios y argumentos racionales y de lógica y no condicionada por los posibles barros diarios de la práctica, asociados a cualquier profesión. René ha sido un maestro para todos aquellos que se han acercado a él buscando consejo o simplemente alguien que les escuchara. René también es maestro para sus hijos y para nosotros. Nos ha enseñado a amar la vida universitaria, la práctica clínica y la investigación. Nos ha enseñado a comprometernos sin miedo. Nos ha enseñado a buscar la recompensa del cariño y respeto de los nuestros y del deber cumplido. Por eso, y por tantas otras cosas, muchas gracias. 


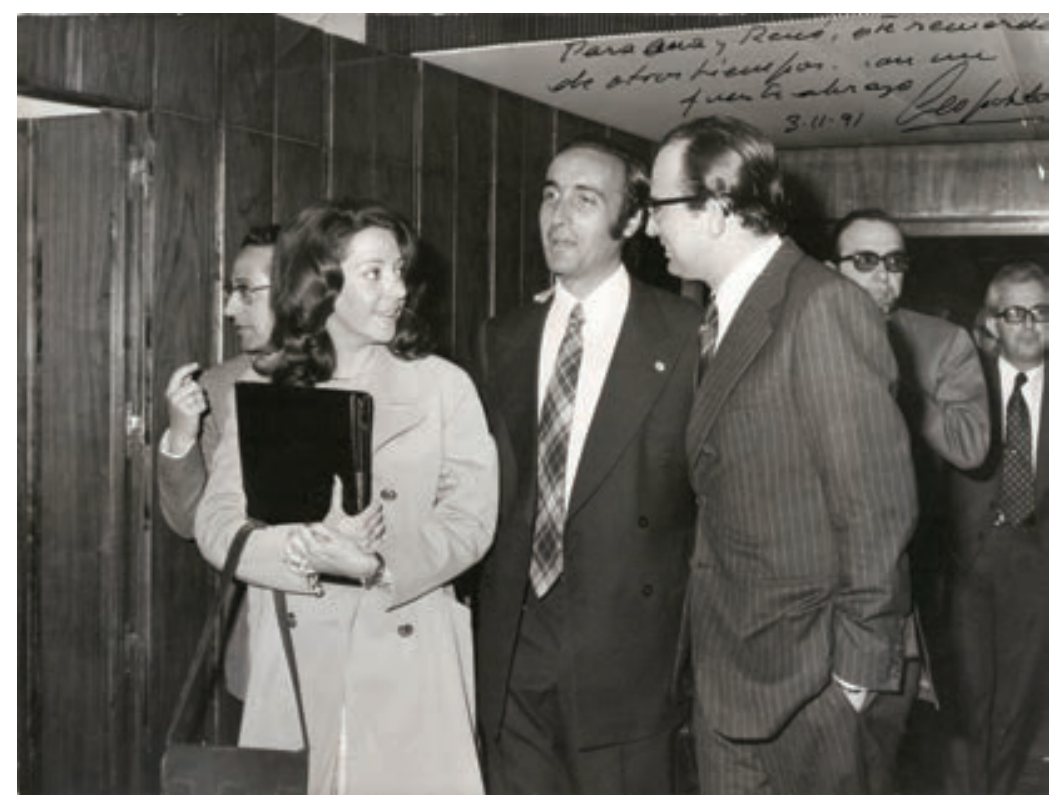




\section{JUBILACIÓN DEL PROFESOR RENÉ SARRAT TORREGUITART}

VÍCTOR SMITH

Catedrático Emérito de Anatomía Humana

Facultad de Medicina y Odontología. Universidad de Valencia

He recibido la noticia de que el profesor doctor René Sarrat Torreguitart, Catedrático de la Facultad de Medicina de la Universidad y Académico de la Real de Medicina de Zaragoza, tras más de 40 años de dedicación exclusiva a la investigación y a la enseñanza, se jubila. Ello me ha hecho detener la vorágine del ritmo de la vida y evocar los recuerdos de aquellos tiempos pasados, cuando nos conocimos y nos encontramos en el viejo Departamento de Anatomía de la vieja Facultad de Medicina, en la Gran Vía, arropados todos en la Escuela Española de Anatomía del profesor Escolar.

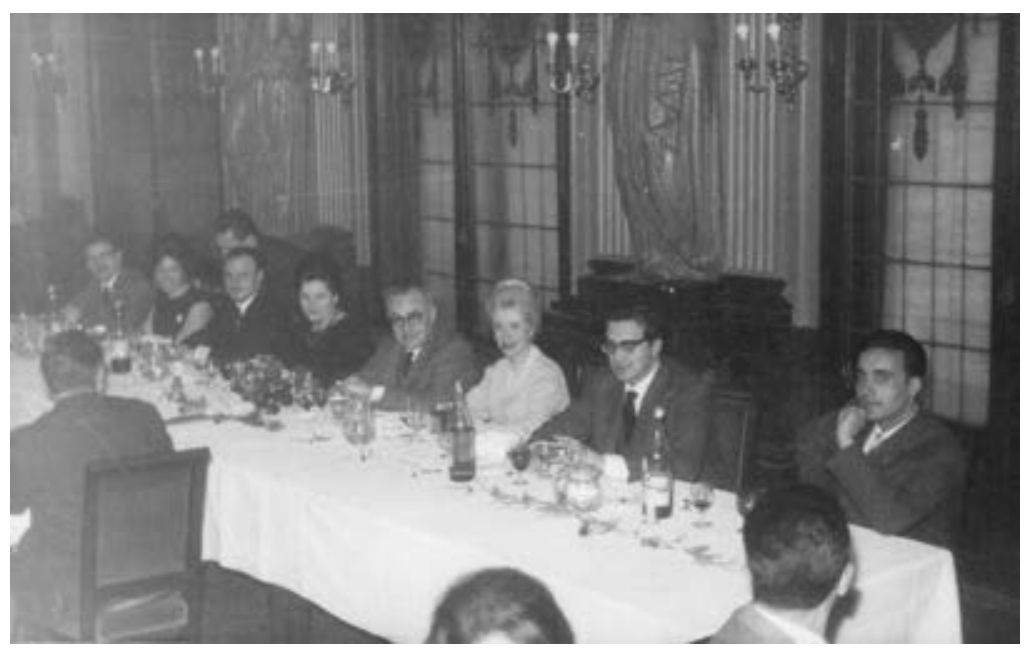

J. M. Smith, Sra. Dr. Amat, V. Smith, Sra. Dr. Escolar, J. Escolar, E. Ferres,

P. Amat y R. Sarrat 
Cuánto tiempo ha pasado desde entonces..., cómo se intenta actuar sobre los circuitos reverberantes de Ranson en el isocórtex heterotípico molecular de la circunvolución calloso-marginal, para interferir en ellos con la aportación de los potenciales del área 46 - o de la voluntad consciente-, y evocarlos proyectándolos de nuevo al área del consciente, para volver a vivirlos recordando el tiempo que se fue.

Recuerdo que cuando le conocí, Elvira y yo acabábamos de casarnos, y volvíamos a incorporarnos al Departamento de Zaragoza, al cual acababa de trasladarse el profesor don José Escolar, maestro y director de nuestra escuela, donde estábamos preparando, yo, las oposiciones a Cátedra de Anatomía, y, Elvira, su tesis doctoral.

René era, entonces, un estudiante de los últimos cursos. Interno Pensionado de Anatomía, que se movía entre los alumnos resolviéndoles dudas, ayudándoles a realizar la disección a los jefes de mesa, siguiendo las normas y patrones que marcaba don José, y ayudándoles a montar las Reconstrucciones por Planos de Disección del cuerpo humano. Lo que constituía un estímulo fundamental para inculcar en el alumno la autodisciplina - que algunos consideramos como la señal del comienzo de la madurez-. Esta reconstrucción acababa de completarles el conocimiento del organismo, y les servía, entonces, de complemento de estudio, y durante toda su vida, de elemento de consulta de cualquier duda, eligiesen la especialidad que eligiesen en el futuro ejercicio de la Medicina.

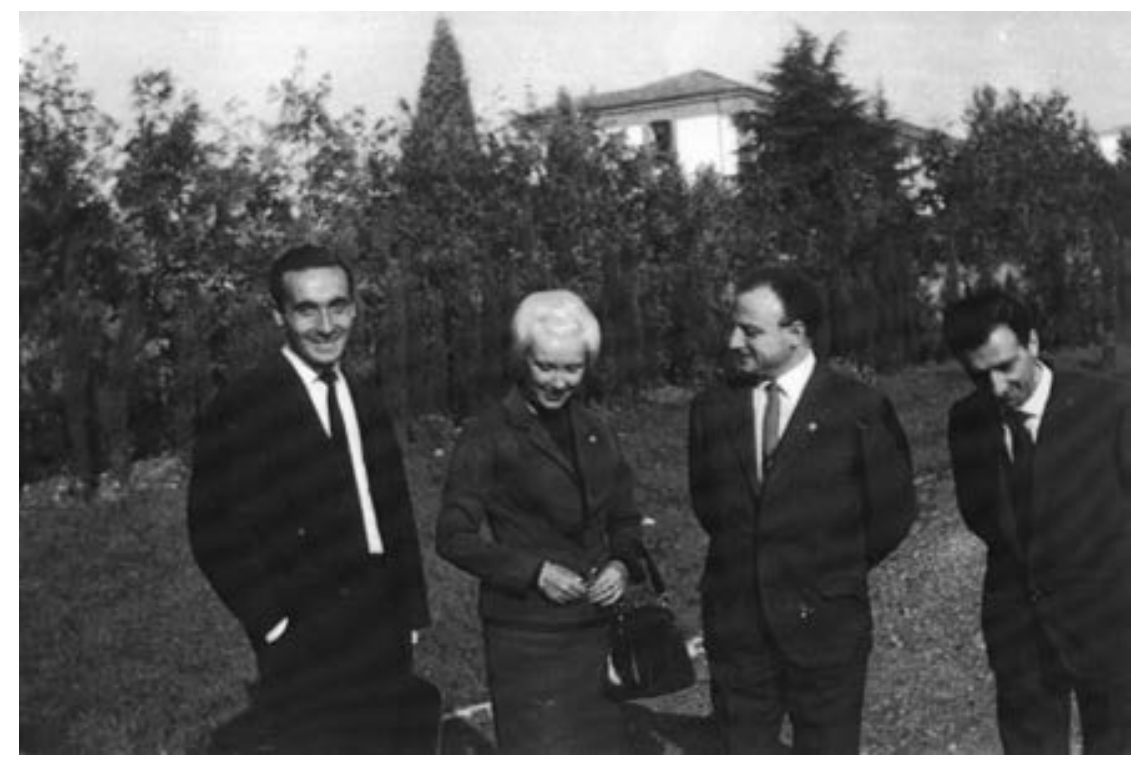

René, Elvira Ferrés, Víctor Smith y José Sandoval 


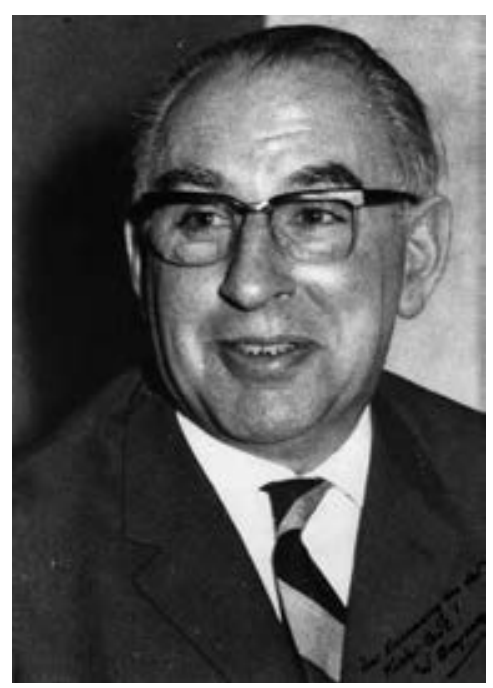

Profesor Bargmann

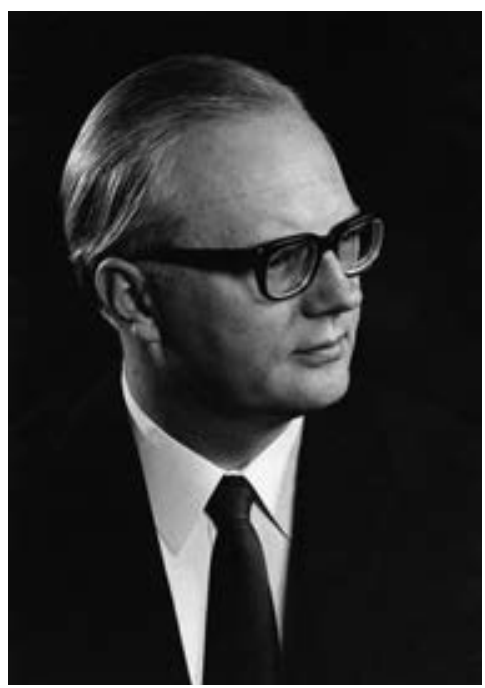

Profesor Schiebler

Allí, trabajábamos en aquel momento —en un espíritu de escuela, ayudándonos unos a otros-, varios discípulos, como Pedro Amat, que fue Catedrático de Anatomía de Salamanca, mi hermano José María, que fue Catedrático de Anatomía de La Laguna (Tenerife), que luego pasó a Málaga, Vicente Calatayud, que fue Catedrático de Neurocirugía de Zaragoza, Elvira que fue Catedrática de Anatomía de una de las cátedras de Valencia, Sandoval, que fue Catedrático de Veterinaria, y después Santiago Rodríguez que fue también Catedrático de Anatomía de Málaga, y después se trasladó a Valladolid, yo, que obtuve la otra cátedra de Valencia, y tantos otros que vinieron después. Allí, entre todos, procurábamos suplir la carencia de medios que teníamos, en comparación con lo que habíamos visto y disfrutado, a través de las becas que sufragaron nuestras estancias en los Institutos alemanes de Anatomía, ya que el momento era duro en España, máxime si te entregabas a la universidad en régimen de dedicación exclusiva.

El tiempo que permanecí hasta mi nombramiento de catedrático, lo recuerdo muy agradablemente y, además, tanto Elvira como yo, pudimos conocer a René, que era un hombre estudioso, agradable en el trato, educado, con gran capacidad de trabajo.

Cuando terminó la licenciatura y leyó su tesis doctoral, se marchó a Alemania pensionado, al Departamento anatómico de Kiel, bajo la dirección del profesor Bargmann, a trabajar en el sistema Hipotálamo-hipofisario, que era el mismo tema en que yo había trabajado en Giessen, en el Max-Planck Institut bajo la dirección del profesor Spatz. 
Traigo esto a colación, porque los conceptos que había sobre la neurosecreción en estas dos Escuelas alemanas, eran completamente distintos, en cada una de ellas. Para Spatz y la Escuela del Max-Planck, las neuro-hormonas, o neurosecreción, se liberaban en los telodendrones hipofisarios, de los elementos macrocelulares de los núcleos hipotalámicos, y cuyo final del metabolismo lo realizaba el pituicito o célula glial del lóbulo posterior. Los de la Escuela de Kiel interpretaban como neurosecreción al producto de reacción del proceso, es decir, lo que la escuela del Max-Planck de Giessen consideraba como neuronosecreción, que era la reacción del proceso, y lo que se teñía por el método de Gomori, y bajaba micro-goteando a lo largo del axón hasta llegar al lóbulo posterior.

Cuando René volvió de su estancia en Alemania, entre nosotros no tuvimos ninguna discusión, pues cada uno exponíamos los conceptos ateniéndonos a la sistemática de la filosofía existencial, es decir, en un diálogo tranquilo y reposado, lo que nos llevó a comprender, respectivamente, puntos que no teníamos claros dentro de nuestras teorías.

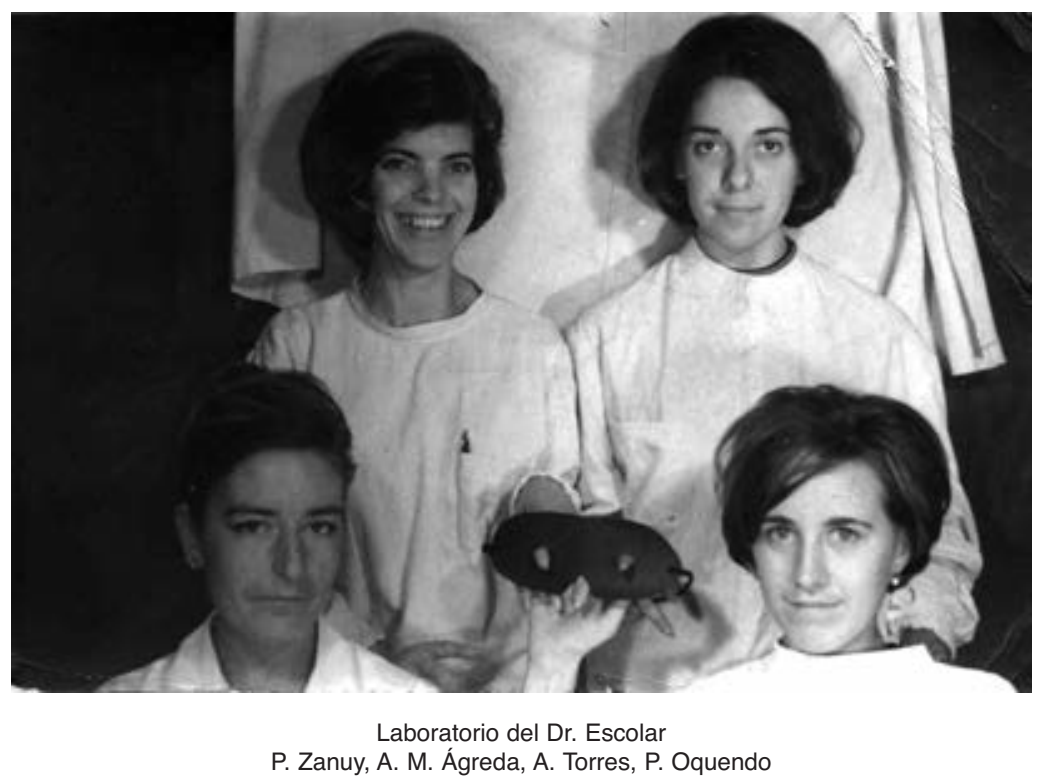

Fruto de estos diálogos fue que, después al separamos - por marchar Elvira y yo a Valencia-, ambos grupos, nos ceñimos al estudio de la superficie de contacto adenoneuro-hipofisaria, lo que nos llevó a reseñar la presencia de comportamientos morfofuncionales similares en la biodinámica de estas regiones. 
Nosotros, en Valencia, describimos el arranque de un sistema porta de asas largas, que en el hilio hipofisario intervenía en el intercambio de la neurosecreción, en el tallo hipofisario. Así mismo, a este nivel se sorprendían procesos donde se realizaban fenómenos de orocrinia, al perderse el Mantelplexus de Romeis, que era una verdadera frontera hemática entre los lóbulos adenal y neural, constituyendo un lugar en donde, de todo el lóbulo adenal, únicamente aparecían mitosis de las células adenales formando una cuña de penetración, que denominamos «zona en cuña sin barrera hemática».

Sarrat junto a Mestres — un compañero suyo de Zaragoza-, estudiaron y demostraron la capacidad de procesos de neurosecreción en la superficie de contacto entre los lóbulos adenal y nervioso, en los animales experimentalmente sometidos a una dieta de sed. Así como realizaron la descripción a este nivel de la neoformación de una arteria hipofisaria ascendente satélite de este proceso morfológico.

Tras nuestra marcha a Valencia, nuestros contactos se hicieron más distanciados, pero solíamos vemos en los viajes que la Escuela de Escolar hacía a otras universidades donde tenía algún catedrático de ella realizando una especie de congresos particulares, y de ellas recordamos las que hicimos a Pamplona, a Salamanca, a Zaragoza, así como la realizada a Valencia.

Cuando coincidíamos en Zaragoza — por asistir a algún tribunal de tesis doctoral- recordamos tanto Elvira como yo el trato agradable de Ana, René, José Luis, Carmen y demás profesores que formaban parte de estos tribunales. Aún recuerdo cómo le gustaba contarme sus aventuras de cacerías, mostrándome fotos de las piezas que había obtenido. Entre ellas recuerdo una en la que aparecía en la puerta de una casa de campo, llevando multitud de perdices, sujetas al cinturón.

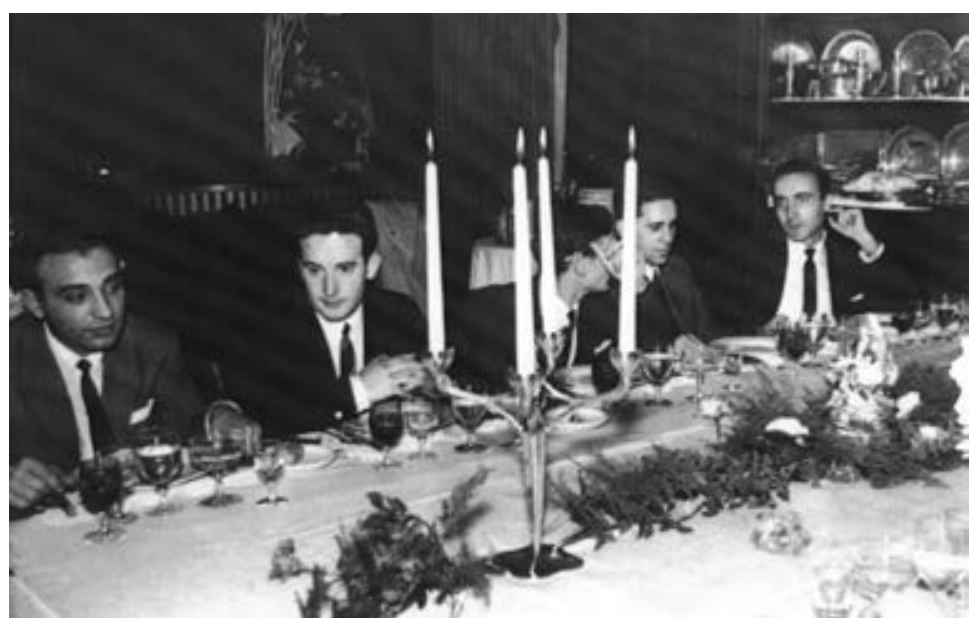

Gabriel Bernal con otros compañeros de la Universidad de Salamanca y René Sarrat 
Además de su valor intelectual, es una persona que destaca por el humanismo de su personalidad, y aun antes de que la biología demostrase que, en la especie humana, el sexo fuerte es el Xx, ha tenido y tiene ideas muy claras en relación a la capacidad intelectual de la mujer, como lo demuestra el hecho de que Ana, su esposa, ha luchado en igualdad de condiciones y ha conseguido acceder al Profesorado Titular, coronando las oposiciones que marca la Ley, sin distinciones de género, con respecto a los ciudadanos españoles.

Esto ya lo había demostrado en el año 1975, cuando, en aquellos tiempos, junto con Escolar, Amat, Anitúa y él, en Madrid, tras la oposición a Cátedra, votaron a favor de Elvira, convirtiéndola en la primera mujer Catedrático de Anatomía y de Medicina de una universidad española.

Como es natural, Zaragoza ha sabido reconocer sus virtudes, capacidades y métodos científicos que posee, y lo han incorporado como académico de número de la Real Academia de Medicina de Zaragoza. 


\section{RENÉ SARRAT TORREGUITART, AMIGO, COMPAÑERO Y RECEIVING EDITOR DE LA REVISTA EUROPEAN JOURNAL OF ANATOMY}

RICARDO VÁZQUEZ

Catedrático de Anatomía Humana. Universidad de Salamanca

A René Sarrat con todo mi cariño, simpatía, admiración y respeto.

Desde hace más de cinco siglos, en 1432, la Universidad de Salamanca instauró la Jubilación de sus Catedráticos; se debió a una modificación del papa Eugenio IV a las Constituciones de su antecesor Martín V (posiblemente sea este último quien figura en los numerosos sellos existentes del Estudio Salmantino). En una de sus constituciones aparece la disposición por la que los Catedráticos que hubieran leído en sus Cátedras durante 20 años, tenían derecho a cobrar el importe íntegro de sus dietas; fue la primera universidad que adoptó el término de Jubilados, en similitud al jubileo de los hebreos, los cuales, cada 50 años, en una fiesta solemne, perdonaban las deudas o daban libertad a los esclavos. Es obvio que este hecho se fue extendiendo por todas las universidades, siendo después una conquista social que permite recibir una remuneración económica, tras un tiempo determinado, por el ejercicio de su carrera o destino.

No hay duda de que el hecho de jubilarse es esencialmente un júbilo, un merecimiento, un premio, un derecho por el trabajo realizado, para aquellas personas que han dedicado la mayor parte de su vida al ejercicio de su profesión y tu, René, eres una de ellas.

René, nos conocimos hace bastantes años, en fechas que ya están en nuestro recuerdo, cuando nos reuníamos todos los que de forma directa, como tú, o indirectamente, como yo, formábamos parte de la Escuela del profesor Escolar; ya en aquellas reuniones, tú con más experiencia, cambiábamos impresiones sobre docencia, pero más aún sobre investigación, acerca de objetivos planteados, cómo nos estábamos formando o cómo queríamos aplicar una u otra técnica. Tu influencia alemana era patente y tu respeto a los que te habían enseñado, un ejemplo.

Se fue agrandando nuestra amistad a medida que íbamos coincidiendo en la Facultad de Medicina de la Universidad Complutense de Madrid, con motivo de oposiciones a cátedras de Anatomía (todavía no existía la figura de profesor Agregado), que 
en aquellos años eran largas, duras y de gran intensidad. Sin embargo, las oposiciones nos permitían enriquecernos en algunos aspectos que nos dejaron huella, por ejemplo, aquellos paseos por el claustro del primer piso del edificio, hablando de nuestros problemas, en un intenso estado de nerviosismo y durante todo el periodo que duraba la oposición; el entrar, de vez en cuando, en aquella sala de grados, donde unos y otros exponíamos el ejercicio correspondiente, sin hacer ruido para no molestar, sirviendo para hacer los comentarios oportunos; palpar la tensión entre opositores y acompañantes, en todos y cada uno de los ejercicios, fundamentalmente en los prácticos, como era aquel quinto ejercicio en el que teníamos que realizar una disección lenta que duraba seis horas, otra rápida de media hora y analizar un corte embrionario e interpretar imágenes radiográficas en escasos minutos, después de estar aislado y como un toro manso y asustado, quedarte, a oscuras, delante de las piezas a interpretar.

Durante esos días de oposiciones, comentábamos las incidencias, las circunstancias que se producían, los nerviosismos, las anécdotas y nos consolaban bastante las charlas entre amigos, independientemente de la escuela que fueran; eran fundamentales los comentarios con el Sr. Muñoz, el «bedel de las oposiciones» y su famosa libreta llena de anécdotas, donde tenía apuntadas todas las oposiciones que allí se iban celebrando, que conocía los distintos recovecos de aquellas aulas, que vaticinaba por unos determinados opositores que iban a ser los candidatos; se estaba al tanto de las salidas y entradas de los miembros del tribunal, si se ausentaban del tribunal o no, del aspecto de sus caras, si comentaban alguna cosa o solo eran caras serias y, llegado el momento de votación, se esperaba la llegada del Sr. Sierra, jel señor de la cartera!, jel señor del ministerio!, siempre el mismo, que aparecía en el momento oportuno, de máxima tensión para nosotros y, en breve ya, para pasar a la sala, llamarnos y comunicarnos, en ritual votación, el resultado de las pruebas. Así, una y otra vez, hasta que tú, René, bastante más pronto que yo, obtuviste de forma merecida, la plaza de catedrático de universidad.

Fueron años muy duros, de angustia, pero que forman carácter y construyen tolerancia, como muy bien dejaste escrito en Notas escritas, a las que me referiré más tarde y a lo que yo añado años en los que se fraguó una gran amistad que después se fue manteniendo a lo largo del tiempo y que perdura en estos momentos; todos somos conscientes que la amistad en los años de carrera es algo fundamental para todos y algo similar ocurría en aquellos otros años en los que, viéndonos en la Facultad de Medicina de Madrid, en congresos de Anatomía o en las reuniones de la Escuela, se fue marcando esa estrecha amistad de la que antes estaba hablando.

Es cierto que, como todos aquellos otros que estaban al lado de don José, no solo se buscaba la formación docente en el campo de la Anatomía, sino también la formación investigadora; la influencia alemana sentó en ti unas bases bastante sólidas para poder cimentar esa orientación que todo universitario debe tener y que, dándote experiencia, te capacitaba para que, cuando llegara el momento, las personas que estaban a tu lado se beneficiaran de esas bases. Además, fuiste agradecido con todos aquellos que 
te enseñaron a investigar, empezando por don José, que influyó también en otros muchos que seguimos su campo de investigación. Siempre fuiste inquieto, buscando nuevos alicientes, lo que te hizo cambiar de destino, Bilbao, Las Palmas, Zaragoza; incluso, buscaste siempre nuevos retos, buscar soluciones, resolver problemas; te dieron, como tú mismo has dicho, la gran oportunidad de ir reflexionando en lo becho cada dia, en tener una mayor experiencia, en rectificar en lo equivocado $\mathrm{y}$, así, de manera lenta pero progresiva fuiste enseñando Anatomía a muchos estudiantes y formando discípulos hasta llegar a este último periodo de finalización de tus tareas profesionales.

Tu inquietud te llevó a seguir ampliando conocimientos, conocer otras facetas científicas; siempre con sacrificios, generalmente compartidos con tu esposa e hijos, pero que, bien seguro, han dado un rendimiento y te han hecho más fuerte y con una mayor visión para enfrentarte a los problemas.

A tu dedicación entusiasta a la familia y a los temas profesionales se unieron otros, que han sido claves y fundamentales para la situación de la Anatomía actual. Uno de ellos es tu participación en los procesos de cambio, que afectaron al desarrollo de la Sociedad Anatómica Española y a dar el impulso necesario para hacer despertar a los anatómicos españoles, en momentos en los que se dejaba ver la existencia de crisis de identidad y digo bien despertar pues existía mucho conformismo entre nosotros y era necesario un toque, buscar alicientes, animar y, de ello, doy fe, que lo conseguiste; con tu participación, en los cambios en la Sociedad Anatómica Española, interviniendo en todas aquellas reuniones, que junto con otros compañeros, después del congreso de Córdoba, llevamos a cabo en el Departamento de Anatomía de la Facultad de Medicina de la Universidad Autónoma de Madrid y que desembocaron en unos nuevos estatutos de la Sociedad y en un cambio del dinamismo de la misma, a partir de los años noventa. La Sociedad Anatómica Española siempre reconoció la labor que tú desempeñaste y el apoyo que diste a la nueva directiva que, desde un comienzo, fue esencial para su posterior desarrollo.

Además, quiero aquí recordar un escrito tuyo en aquel boletín de Noticias SAE, en su apartado «La Anatomía vista por...», en el que se exponían los puntos de vista sobre nuestra disciplina por anatómicos de experiencia; en ella tú hiciste una valoración muy atinada en relación con los problemas de la Anatomía española; ya decías entonces, «los jóvenes universitarios tienen muy claro que el tiempo que dediquen a la docencia, el que gasten en tutorías formando al alumno, es tiempo perdido a la hora de ser evaluados en un concurso». Esto y otras cosas muy atinadas, afirmo en estos momentos, sirvieron de acicate, de revulsivo, para muchos anatomistas jóvenes para que, entre todos, se intentara revalorizar, cosa que se fue consiguiendo, la Anatomía Española, consiguiendo un conjunto de profesionales que hicieron que la Sociedad Anatómica Española fuera considerada a nivel europeo, se celebraran reuniones conjuntas con otras Sociedades europeas, llegando a ser una de las Sociedades de Anatomía Europeas más importantes. Es cierto que estos problemas siguen existiendo y la investigación sigue muy revalorizada frente a la labor docente. 

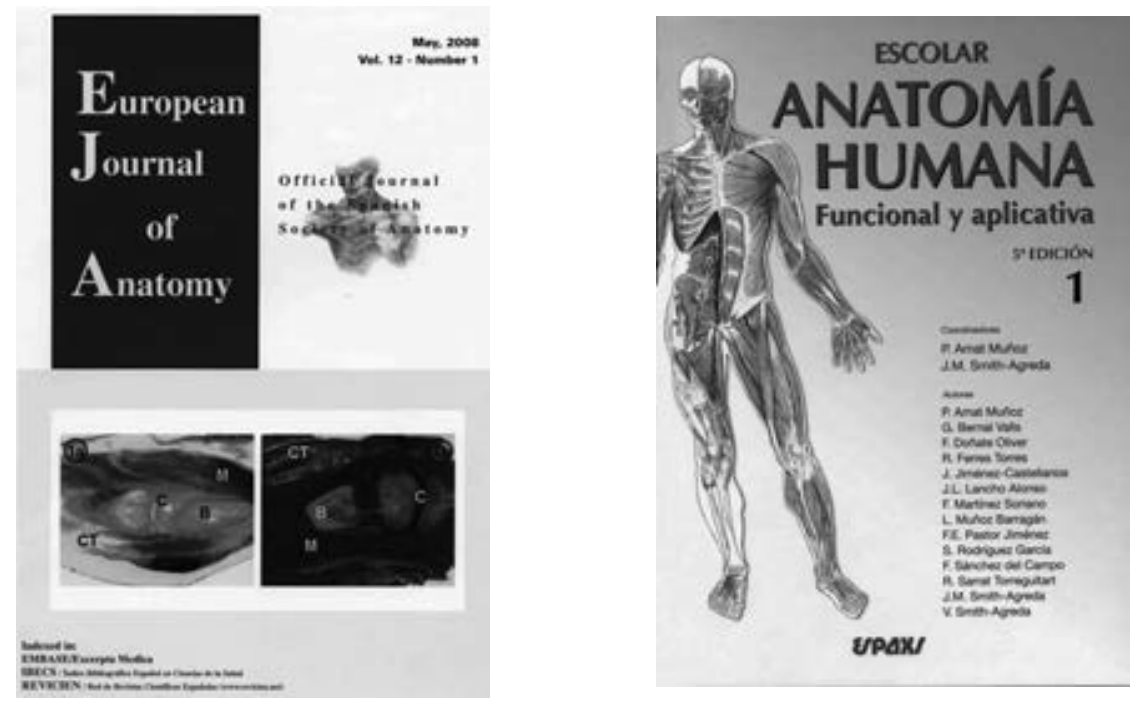

Quiero resaltar tu relación con la revista European Journal of Anatomy, de la que eres Receiving Editor.

El profesor don José Escolar fue el fundador de la revista científica que llevaba el nombre de Anales de Anatomía. La misma comenzó a editarse en Granada para después continuar en Zaragoza, lugares donde don José llevaba a cabo su labor docente e investigadora, junto a un grupo de sus discípulos. La revista llegó a ser, con el tiempo, el órgano de expresión de diversas Facultades de Medicina, como Zaragoza, Salamanca, Navarra, Valencia, Sevilla, La Laguna, Autónoma de Madrid, Córdoba, Bilbao, Málaga, junto con el Consejo Superior de Investigaciones Científicas, y cumplía una exigencia de aquellos años y junto a otras revistas que desaparecieron pronto, los anatómicos podíamos publicar en nuestro idioma, pues era difícil o muy difícil publicar en revistas extranjeras editadas en inglés, francés o alemán.

La revista editaba publicaciones de diferentes miembros de la comunidad científica, nacionales o extranjeros, pero fundamentalmente de aquellos que, como se decía entonces, pertenecíamos a la Escuela del profesor Escolar.

Cuando la revista dejó de publicarse, allá por 1983, fue cuando tú, René, tomaste el relevo de la misma y nos animaste a que, aunque existiendo muchas dificultades, la revista volviera a salir, cosa que sucedió unos años más tarde. En tu recuerdo estarán, como lo están en el mío, los grandes obstáculos que tuviste que vencer para poder seguir editando la revista en Zaragoza; dificultades económicas, dificultades para tener un número de trabajos suficientes, dificultades por ser una revista en lengua española, recelos entre los anatómicos españoles, pues daba la impresión de que solo podían publicar 
aquellos que pertenecían a la órbita escolariana; todo ello dio lugar a una gran incertidumbre, a un desasosiego y a la creencia, cada vez más palpable, de no poder continuar $\mathrm{y}$, en efecto, tras muchas reuniones, muchos contactos, muchas horas gastadas en un trabajo que, bien seguro, te costó más de un disgusto, terminaste por arrojar la toalla con un número homenaje, el número 100, con el que se cerró el capítulo de aquella revista que inició el profesor Escolar; esto sucedía en 1993.

Sin embargo, tu gran labor, René, no terminó en ese bonito número, continuó..., más reuniones, más buscar colaboraciones, sin correo electrónico, sin Internet, con escasísimo dinero, pero con una gran ilusión, pues era necesario buscar soluciones, encontrar una editorial que se hiciera cargo de la publicación, que se editara en inglés pues todas las revistas, a nivel mundial, así lo hacían o habían desaparecido. Pero aquello resultaba caro, aunque tú seguías con toda ilusión y con gran tenacidad, pues a toda costa querías que la revista volviera a salir publicada y preparaste diseños, buscaste apoyo del rectorado y la luz se abrió con la ayuda de la Sociedad Anatómica Española que decidió, a través de sus órganos de Gobierno, la Junta Directiva y la Asamblea General de socios, que la Sociedad tuviera su Revista, que se iniciara con otro nombre, European Journal of Anatomy, en inglés y que fuera el órgano de expresión de la misma, intentando resolver el problema económico que ello conllevaba.

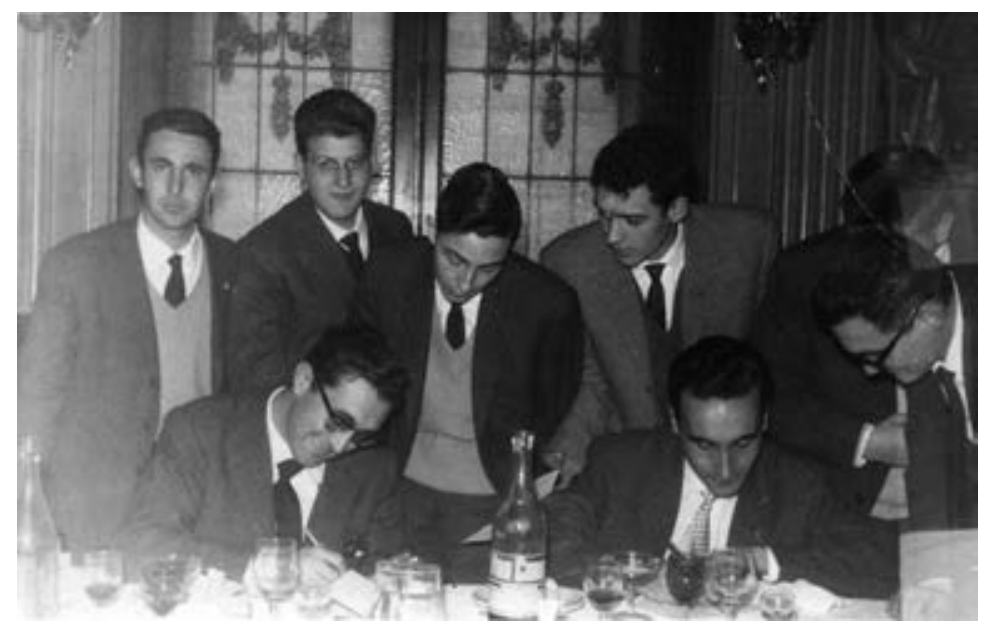

Pedro Amat y René Sarrat en primera fila

No sería una continuación de Anales de Anatomía, pero sí una continuación de tu espíritu investigador y tú serías, no faltaba más, Receiving Editor; su número primero apareció en 1997, llevando pues más de diez años de andadura y, como decíamos antes, tú empezaste siendo editor de la misma, junto con el que esto está escribiendo y con otros compañeros. 
Como amigo tuyo, recibí siempre tu ayuda en los momentos difíciles de nuestra carrera profesional, sobre todo en aquellos momentos en los que existía incomprensión y desaliento dentro de nosotros; en muchas ocasiones esta ayuda la tenía de tu esposa Ana a la que, por supuesto, tengo que estar agradecido. Además, la ayuda y apoyo tuyo y de Ana también se extendieron a mi esposa y así hemos pasado ratos buenos, bonitos de recordar; últimamente, por las vicisitudes de la vida, mi familia está afectada y tengo que decir que, durante todo este tiempo difícil, que ha cambiado mi rumbo e, incluso, mi forma de pensar, siempre conté con vuestra ayuda y os lo agradezco de todo corazón. Nuestras esposas nos han ayudado en los momentos difíciles, siempre estuvieron a nuestro lado y lucharon, dándonos ánimos, por nuestra disciplina, querida por nosotros y maltratada por otros muchos.

He querido, con estas líneas toscamente escritas, expresarte, mi cariño, pues has sabido tener y mantener un profundo afecto hacia mí y hacia mi esposa; mi simpatía, pues siempre tuvimos unas ideas muy parecidas en cuanto a la forma y manera de llevar nuestra profesión, los problemas, el enfoque docente e investigador en nuestra profesión, mi admiración, pues te consideré siempre y te sigo considerando, más experto, muy bien formado, con grandes ideas y, así, cuando existían dudas en cualquier aspecto, siempre recurría a ti y todo esto no se olvida y mi respeto debido a que tu comportamiento conmigo fue siempre como el de un maestro y así he de reconocerlo.

Estas líneas han querido plasmar tu aportación a la Anatomía española en estas facetas concretas, Sociedad y Revista, pues en otras, serán otras personas las que lo hagan. Hubiera querido haberlo hecho mejor pero tengo mis limitaciones; no obstante, puedes estar seguro de que, siendo como soy muy afectivo, lo he escrito, saliendo de la rutina de la redacción de los trabajos científicos, de todo corazón.

Te deseo toda la felicidad posible y pido a Dios, que todo lo puede, según nuestras creencias, que junto con tu familia disfrutes lo más posible de esta jubilación que, por supuesto, tienes más que merecida. 


\section{SEMBLANZA DE RENÉ SARRAT, EL HOMBRE, EL PROFESOR Y EL AMIGO}

JOSÉ M. a SMITH ÁGREDA

Catedrático de Anatomía. Universidad de Málaga

InÉS FERNÁNDEZ ORTEGA

Profesora Titular de Anatomía. Universidad de Málaga

En el curso académico 1955-56, el alumno de Medicina René Sarrat Torreguitart estaba comenzando sus estudios de licenciatura. Al poco tiempo de ingresar en la universidad, un alumno de sexto curso le ofreció una participación en la Lotería Nacional de Navidad pro viaje de estudios. En el talón aparecía el nombre del depositario, un tal José M. ${ }^{a}$ Smith Ágreda, uno de los que esto escribe.

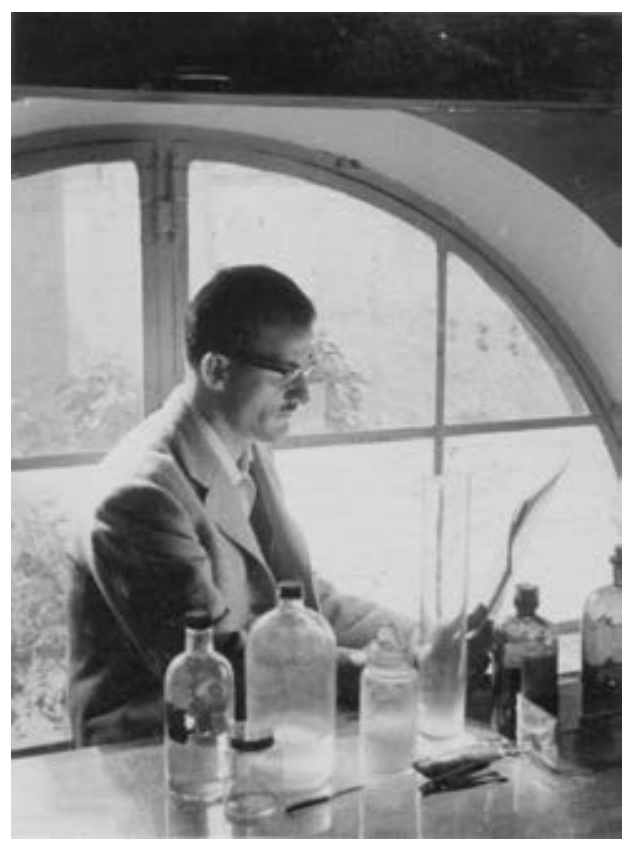


De aquello hace ya muchos años. Muchas cosas han pasado y muchos aspectos han cambiado. En aquella participación de lotería, el portador del talón interesaba la cantidad de cuatro pesetas (hoy, al cambio, no llegaría a tres céntimos de euro), pero, de haber sido agraciado aquel número -48167-, hubiera aliviado nuestra precaria situación económica. Los alumnos que por oposición obteníamos el nombramiento de alumno interno pensionado, entre los que se encontraría en su momento el estudiante René Sarrat, recibían 125 pesetas mensuales, una fortuna para un estudiante, siempre con la condición de vivir en Zaragoza y en casa de sus padres. Con todo, debió de haber tiempos mejores, pues el nombramiento parece que en algún momento permitió al estudiante afrontar todos los gastos de su pensión.

Años más tarde coincidimos en el Departamento de Anatomía en Zaragoza. El profesor don José Escolar se había trasladado a esta Universidad procedente de Granada en el curso 1958-59; José M. ${ }^{a}$ Smith se incorporaba al Departamento al curso siguiente de regreso de la Universidad Johannes Gutenberg de Mainz, Alemania; René, alumno interno pensionado, estaba terminando la licenciatura. En el año 1963, en el que tres compañeros del Departamento lo dejaban, Víctor Smith (para hacerse cargo de la cátedra de Valencia, obtenida por oposición), con él la doctora Elvira Ferres, su mujer, y Pedro Amat (que asumía la cátedra de Salamanca, también obtenida por oposición), el licenciado en Medicina y Cirugía René Sarrat obtenía el grado de doctor, y dos nuevos licenciados, Santiago Rodríguez e Inés Fernández, se incorporaban para comenzar su tesis doctoral, así como el doctor en Veterinaria José M. a Sandoval.

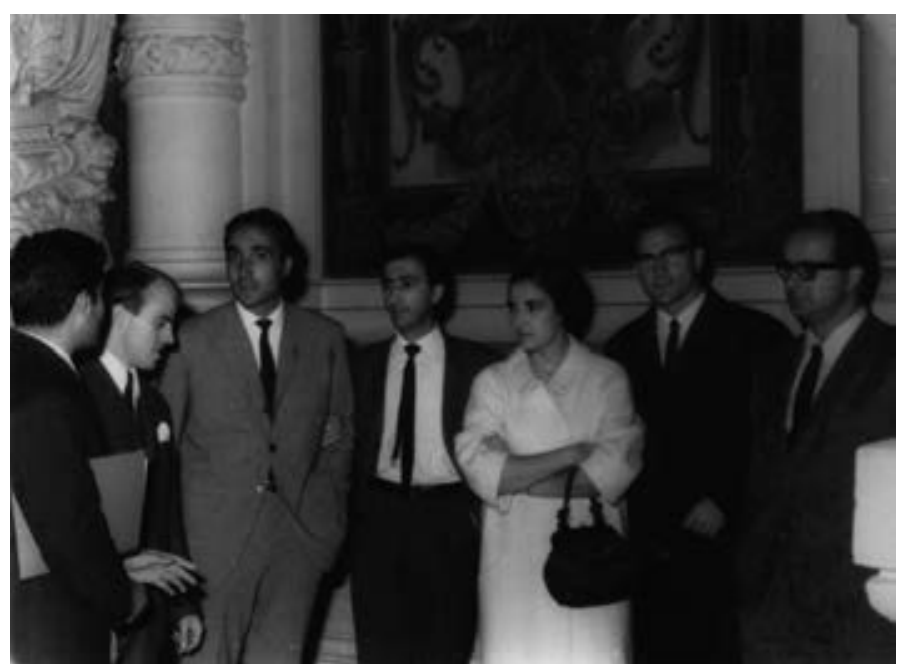

Juan Saldaña, René Sarrat, José Sandoval, Inés Fernández, José M. ${ }^{a}$ Smith 
El profesor Escolar nos hizo amar la Anatomía y hacerla meta de nuestra actividad profesional a muchos licenciados en Medicina que dejamos los sueños de ser médicos internistas, médicos de cabecera (actualmente médicos especialistas en medicina familiar y comunitaria), o especialistas en urología, o neurocirujanos, para llevarnos a intentar trasmitir a los que nos sucedieran el entusiasmo por la ciencia anatómica y por su enseñanza en régimen de dedicación exclusiva, en un tiempo en que plantearse este tipo de dedicación a la universidad (que hoy sería a tiempo completo), desde el punto de vista económico, era muy arriesgado, casi suicida, ya que, o bien obtenías la cátedra o habías fracasado, ya que no existía otra titulación de profesor.

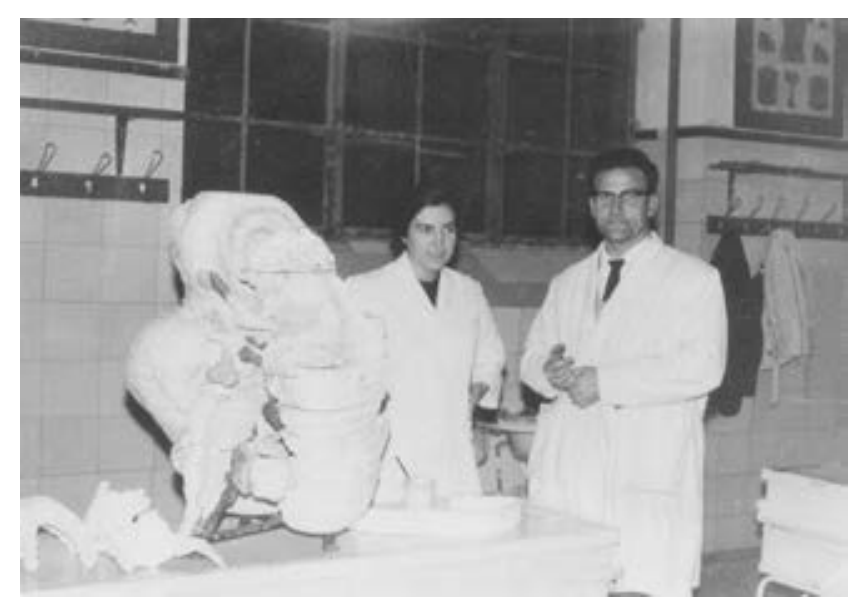

José M. ${ }^{a}$ Smith junto a Inés Fernández

De los que coincidimos al lado del profesor Escolar en aquel Departamento ubicado en el entrañable pabellón de Anatomía con su pequeño anfiteatro (Sala Amarilla) pabellón que no se supo, o no se quiso conservar, al dejar la Facultad el noble edificio de finales del siglo XIX y que derribó la piqueta, muy activa en Zaragoza demoliendo edificios que hablaban del pasado, nos hemos jubilado ya muchos: Víctor Smith Ágreda y Elvira Ferres Torres en Valencia, Pedro Amat Muñoz en Salamanca, José M. ${ }^{a}$ Sandoval Juárez en León, José M. ${ }^{a}$ Smith Ágreda e Inés Fernández Ortega en Málaga. Ahora, en este curso 2007-2008, les toca a Santiago Rodríguez García en Valladolid y René Sarrat en Zaragoza. En aquellos tiempos, entre nosotros, hablábamos de chicas, después de novias, más tarde de mujer e hijos, y ahora de nietos...

Recuerdo cuando don José, refiriéndose a René Sarrat (y como si yo hubiera tenido arte o parte en ello), me dijo: «ihemos hecho un buen fichaje, José María!». Un fichaje que iba a prolongarse para bien de la Anatomía, la Facultad de Medicina y la 
Universidad, ¡cuarenta y siete años! Creo que el Estado otorga la pensión de jubilación máxima a un profesor universitario si ha estado treinta años cotizando, olvidándose del total de más que hayas estado entregado a tu trabajo (y también cotizando). El profesor Sarrat ha estado haciéndolo durante diecisiete años más.

La amistad forjada en los años que estuvimos juntos en la Universidad de Zaragoza (hasta finales del curso 1969-70) nos permitió conocerlo bien a él y a Ana Torres, su mujer. Al dejarnos los profesores Víctor Smith y Pedro Amat en 1963, pudimos René y yo ubicarnos en lo que había sido su «despacho». Bueno, en realidad no era más que una habitación del segundo piso del Departamento que era también laboratorio, y tenía dos mesas de despacho pegadas la una a la otra —entre las dos dudo que sobrepasaran la superficie de un metro cuadrado-, con un armario bajo y un armario empotrado en el grueso muro a la espalda de las dos mesas donde guardábamos libros, documentación, nuestros trabajos y separatas; en fin, una habitación multiuso que dudo tuviera más de doce metros cuadrados y a la que se le conocía coloquialmente como el «dormitorio de monas». De aquella habitación salimos, yo para ocupar mi primer destino como catedrático en la Universidad de La Laguna en 1970 y René, poco después, para hacer lo propio con la cátedra de Bilbao.

Cuando el destino nos llevó a servir en distintas universidades afortunadamente los congresos, los tribunales de tesis doctorales, las comisiones de oposiciones, las invitaciones a charlas y conferencias ayudaron a terminar de forjar esa amistad y a profundizar en nuestro mutuo conocimiento como personas.

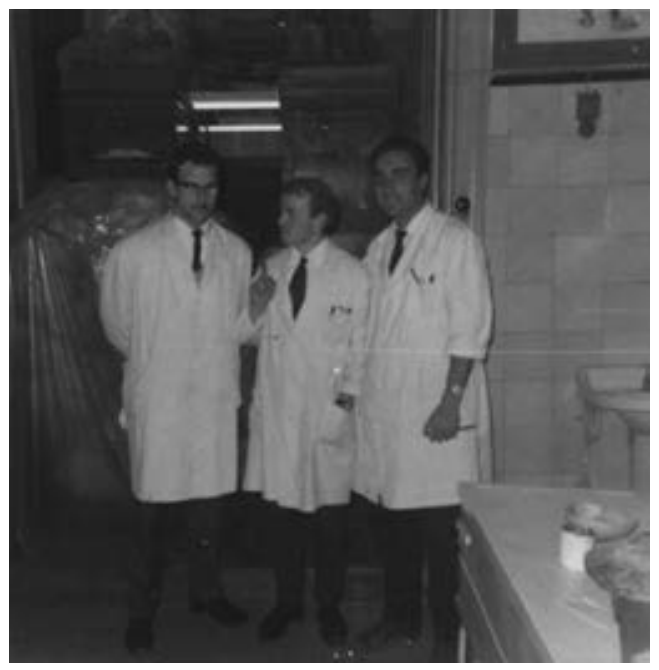

José M. ${ }^{a}$ Smith, Juan Saldaña y René Sarrat en sala de disección 


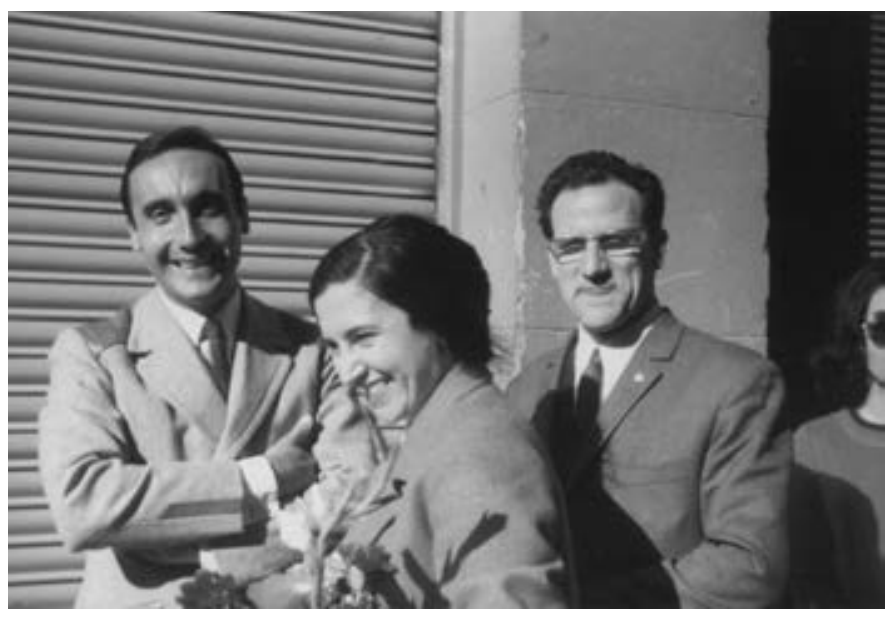

R. Sarrat, I. Fernández y J. M. Smith

El profesor René Sarrat Torreguitart nació en Gimenells, en la franja en donde Aragón y Cataluña se funden o continúan, tierra donde se baila la sardana y se canta la jota como expresión de la fusión de dos temperamentos, y que sin duda influyó en su personalidad de hombre familiar, próximo, generoso, sacrificado, amante del campo, y del trabajo responsable y bien hecho. No tuvimos la ocasión de tratar a su padre al que siempre consideró como amigo dado que se llevaban relativamente pocos años de edad, y que falleció a finales de los sesenta. Conocimos, sin embargo, a su madre, a su hermana Nelly y a sus hijos Rebeca y Marco Antonio, a los que gracias a la hospitalidad suya y de su mujer Ana hemos visto desde pequeños crecer y convertirse en flamantes especialistas médicos. ¡Todo en esa familia ha encajado!

Al profesor Sarrat le ha gustado siempre abordar y resolver bien los asuntos. Recuerdo que en una ocasión se comentaba cierto problema universitario que planteaba equivocadamente el Ministerio, y comentó: « ...y lo malo de resolver las cosas mal, no es que no se resuelvan, es que se resuelven, ipero mal $i^{\text {». }}$

A su regreso de la Universidad de Kiel, donde había estado pensionado al lado del profesor Bargmann, nos inculcó una gran meticulosidad en el trabajo de laboratorio así como nos enseñó nuevas técnicas que ampliaron nuestras posibilidades en investigación.

La docencia en Anatomía, como en cualquier disciplina de la universidad, o se hace bien o más valdría dedicarse a otra cosa. Y hacerla bien requiere una serie de actitudes que, aparentemente, no es difícil tener ni entender, ipero cuánto les cuesta, al parecer, a algunos!

Lo primero es saber. Esto se alcanza estudiando y asimilando lo que otros nos legaron con su palabra, sus escritos y su entrega. El nivel de verdad conseguido por el esfuerzo de muchos deberá ser integrado con los resultados de nuestras propias expe- 
riencias con las que contribuimos, modestamente, a que ese nivel se acerque a la Verdad que debe ser patrimonio no de unos pocos, sino de todos los que la ansían.

Cuando el que sabe se dedica a la enseñanza se convierte en profesor.

Cuando el profesor ejerce la enseñanza con plenitud, con completa entrega, persiguiendo trasmitir sin restricciones sus conocimientos y se fuerza a hacerlo con un método eficaz para ayudar a que quien la reciba pueda elaborar su propio conocimiento, entonces, el profesor alcanza el nivel de maestro al que todos los docentes deben aspirar. Pero para dar ese paso cualitativo se necesita una gran dosis de renuncia a ser el único dueño del saber, para que deje de ser patrimonio de uno, para querer darlo a los otros, y, además, saberlo impartir. En esto radica la esencia de la docencia.

René Sarrat sabe, profesa, y ejerce magisterio, es sabio, profesor y maestro. Cuando enseña Anatomía, el alumno o quien le escucha no solo aprende Anatomía, aprende Medicina y aprende Humanidad. Su Saber lo acredita su labor científica respaldada por la obtención de sexenios, la dirección de tesis doctorales y asistencia a las investigaciones de sus compañeros de equipo. Su Profesión, los cuarenta y siete años de servicio en dedicación exclusiva repartidos entre las Universidades de Zaragoza, Bilbao, en el Colegio Universitario de Las Palmas de Gran Canaria y, desde 1983, otra vez en la por tantos querida Universidad de Zaragoza. Y su Magisterio por las características de impartir la docencia teórica que se completa y respalda en la clase práctica con la disección e interpretación de la anatomía en la técnica de la imagen. Hace unos pocos años la Facultad de Medicina de Málaga recomendó a los diferentes Departamentos que invitásemos a algún profesor de otra Universidad a impartir una clase a los alumnos. El Departamento de Anatomía invitó al profesor Sarrat de la Universidad de Zaragoza. Fue su intervención francamente brillante: se ganó al alumnado y al profesorado. Mitad en broma y mitad en serio, le dijimos: «René ¡ya no te volvemos a invitar a dar una clase, no vaya a ser que nos quites la clientela!».

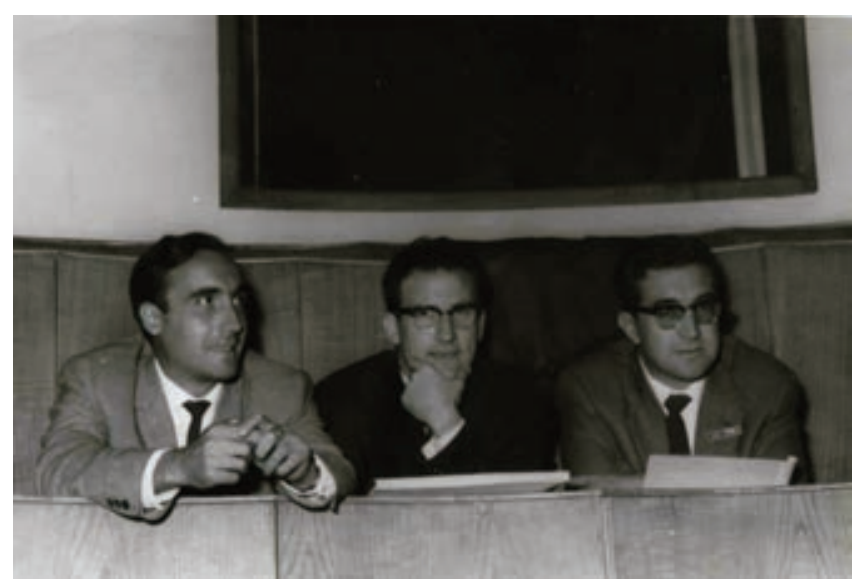

René Sarrat, José M. ${ }^{a}$ Smith y Pedro Amat 
El treinta de septiembre el profesor Sarrat se jubila por ley. Los que estas líneas escribimos ya lo hicimos, uno en el año 2002, el otro en 2004. Tras la jubilación comienza una nueva época. Dicen que la palabra jubilación viene de júbilo. Al principio, ningún enamorado de la enseñanza lo cree ni así lo siente, pero pronto cambia la manera de enfocar cómo vivir el futuro. Es verdad que el camino que se ha andado es ya imposible desandarlo, pero si se recorrió bien, como el profesor René Sarrat lo ha hecho, la fuerza y el vigor pretérito, poco a poco, van siendo sustituidos por días de calma, sabiduría y paz (...y algún que otro achaque) que nos llenan la vida. 


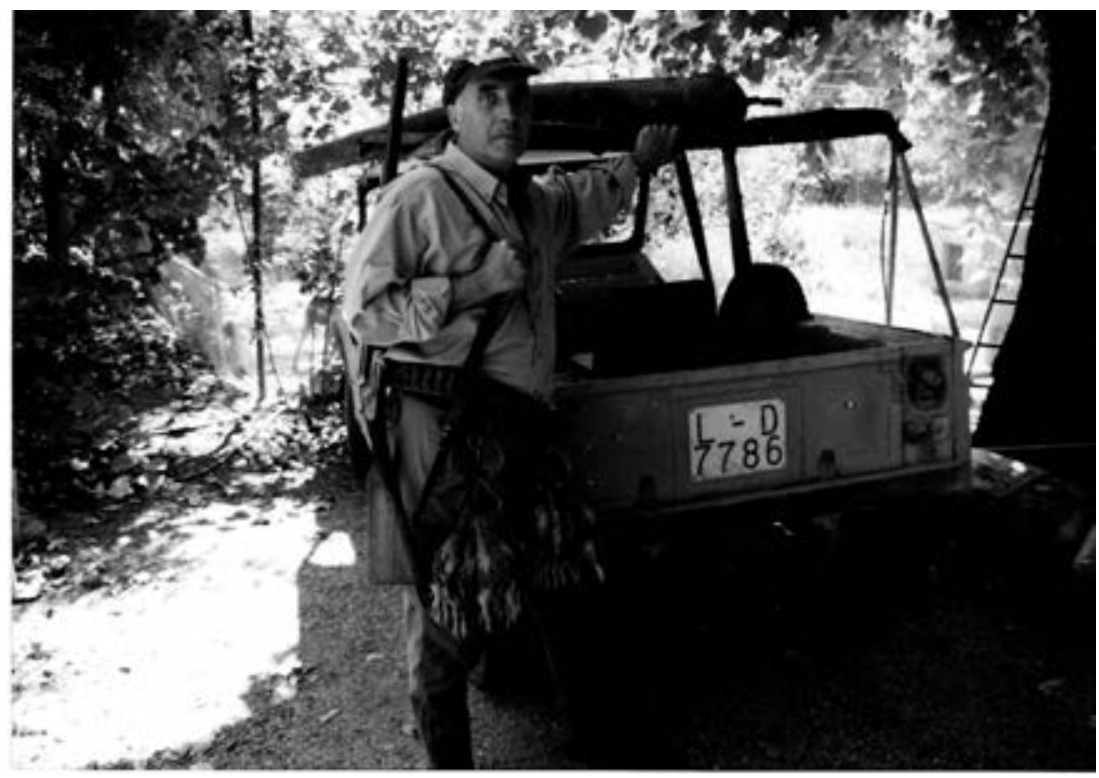




\section{AL PROFESOR RENÉ SARRAT}

\section{JOSÉ LUIS BUENO LÓPEZ}

Secretario General de la Sociedad Anatómica Española

Catedrático de Anatomía y Embriología Humanas. Departamento de Neurociencias

Facultad de Medicina y Odontología. Universidad del País Vasco

Este elogio del profesor don René Sarrat Torreguitart con ocasión de su jubilación está escrito desde una doble perspectiva. La que tengo como Secretario General de la Sociedad Anatómica Española (SAE) y la que me ha dado haber sido alumno de René.

Como secretario general de la SAE he de hacer constar muy sinceramente mi agradecimiento a don René Sarrat Torreguitart por haber sido, junto con otro admirado profesor, don Ricardo Vázquez Rodríguez, editor jefe de la revista Anales de Anatomía, The European Journal of Anatomy, órgano científico de la Sociedad. La coordinación de un amplio comité editorial y la captación de artículos científicos originales, de forma que cada número fuera interesante y llegara puntualmente a las manos de los suscriptores, han sido tareas exigentes que solo personas de calidad como René y Ricardo pueden llevar a cabo con la constancia, abnegación y éxito con que lo han hecho durante muchos años. Soy testigo de los esfuerzos hechos por los dos editores para elevar el prestigio internacional de la revista y tratar que esta entrara en las

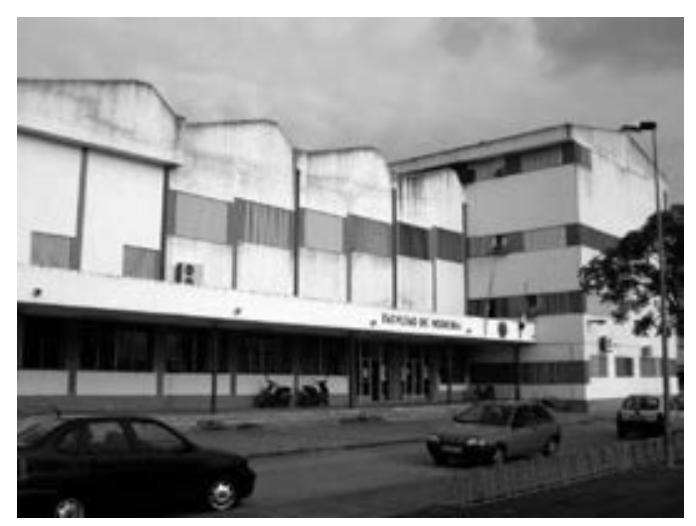

Campus de Leioa. Facultad de Medicina 
listas de índices de impacto más influyentes. Todo ello sin tener que delegar en casas editoriales poderosas, ni pagar a estas un elevadísimo precio anual que hubiera conllevado necesariamente un aumento de cuota que los miembros de la Sociedad hubieran sin duda lamentado.

No tengo la menor duda de que en un futuro muy próximo la Sociedad habrá de tomar importantes decisiones respecto a su revista científica con el fin de hacerla avanzar todavía más; para evitar que desaparezca en el torbellino que agita el mundo editorial científico en la actualidad. Pero tengo ahora la oportunidad de reconocer la gran labor que en el mantenimiento y mejora de la revista ha hecho el doctor René Sarrat Torreguitart a lo largo de años muy importantes para la revista.

Por otra parte, conocí a don René Sarrat Torreguitart cuando él era un joven profesor adjunto y yo un alumno del Departamento de Anatomía Humana dirigido por el profesor don José Escolar García en la Facultad de Medicina de la Universidad de Zaragoza. Para hacer el elogio de René como profesor, he de comentar necesariamente algo de mi vida estudiantil, lo que espero que se me disculpe. En el Departamento de Anatomía de la Facultad de Medicina de Zaragoza cursé las asignaturas «Anatomía Humana (I y II)» y «Técnicas Anatómicas (I y II)» y, además, fui monitor de clases prácticas («jefe de mesa»); todo ello en el bienio entre 1967 y 1969. Posteriormente fui, también allí, «alumno interno por oposición», hasta mi licenciatura en Medicina y Cirugía en 1973. En esos años, que me fueron cruciales para tomar decisiones personales y profesionales, hice los fundamentos de mi formación como anatomista. Mi profesor directo fue don José Escolar García, de grandísimo recuerdo, quien luego además dirigió mi tesis doctoral, mientras me introducía sabiamente en el arte de dar clases teóricas de la ciencia llamada Anatomía Humana a futuros médicos y cirujanos.

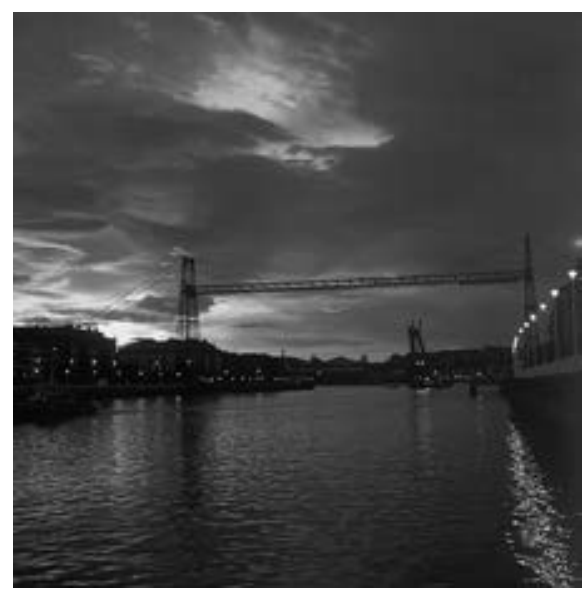

Ría de Bilbao 
Pero mis profesores de disección fueron don José M. ${ }^{a}$ Smith Ágreda, don René Sarrat Torreguitart, don Santiago Rodríguez García y don Pedro Mestres. Las horas que pasé con ellos, disecando diariamente a lo largo de varios cursos en el viejo laboratorio anatómico de la Facultad de Medicina de la plaza de Basilio Paraíso de Zaragoza, fueron muchas e inolvidables. La disección nunca fue aburrida, ni en sí misma y ni, desde luego, con tales maestros. La disección es en la anatomía el paradigma del aprendizaje individual hecho por objetivos, tareas, resolución de problemas o comoquiera que guste la pedagogía llamar según sea la moda. La disección absorbe los sentidos y el intelecto, por no decir la razón: nunca un cuerpo es igual a otro, de todos se aprende. Pero además, mientras se hace personalmente o cuando se observa al maestro hacerla, la disección propicia momentos inenarrables escuchando consejos e intercambiando anécdotas. Todo esto, es decir, el aprendizaje guiado junto a la responsabilidad y la camaradería, es impagable cuando se es estudiante y joven; con el paso del tiempo uno debe agradecerlo si tiene oportunidad, y esto es lo que yo hago ahora gustosamente.

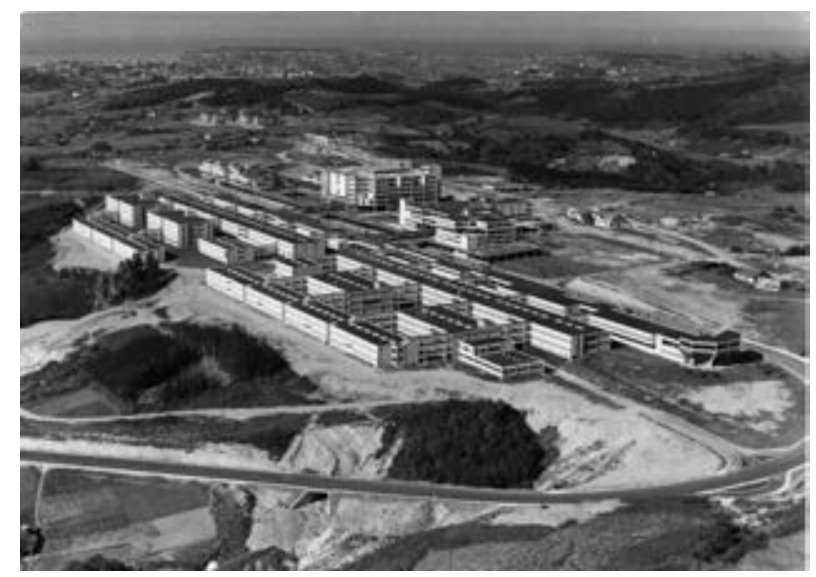

Universidad del País Vasco. Leioa

(Por cierto, y como comentario marginal, diré que de entre las muchas cosas que me quedaron meridianamente claras durante aquellos años, recuerdo haber aprendido que «secar» es cortar y «disecar» es cortar y separar con método; la palabreja «diseccionar» tuvo que ser admitida después por la RAE debido al mal uso que los anatomistas, quizás inducidos por otros profesionales menos conocedores, hicimos de nuestro propio léxico. Pero lo bueno, si breve, siempre será dos veces bueno.) 
René era un gran disector, un excelente expositor y un hombre carismático de enorme y contagioso entusiasmo. Yo tengo el regalo de haberlo tenido como «mi» profesor de anatomía, junto a don José Escolar García y don José M. ${ }^{a}$ Smith Ágreda, en aquellos pequeños grupos organizados en torno a él y sus otros compañeros en la sala de disección. Lo cual está presente en mí cuando diseco y cuando organizo, a mi vez, mis clases y mis exposiciones. Reconozco en René uno de mis maestros; no puedo decir algo mayor. A los maestros se les quiere, se les admira y también se discrepa de ellos y se discute con ellos. Discutí con René en alguna ocasión por algún motivo profesional que no viene al caso. Pero René pertenece a la estirpe de los queridos y necesarios maestros. Para el maestro René, el profesor doctor don René Sarrat Torreguitart, como él gusta de ser llamado al estilo alemán, presento aquí mi testimonio de haber sido, espero que con aprovechamiento, su discípulo. 


\title{
RENÉ SARRAT TORREGUITART
}

\author{
LeONOR HeNNEQUet FERnÁNDEZ
}

Profesora Titular de Anatomía Humana y Embriología. Departamento de Neurociencias Facultad de Medicina y Odontología. Universidad del País Vasco

\section{Profesor y maestro}

Tan solo pensar en escribir sobre el profesor Sarrat me trae a la memoria buenos recuerdos y profundos sentimientos. Redactar estas líneas sobre quién fue mi Profesor y aún es mi Maestro no resulta tarea fácil, porque se entremezclan inevitablemente los datos objetivos con los sentimientos que marcaron mis pasos desde el inicio de mi carrera hasta hoy. Para ello, y aunque parezca un ejercicio contra la más elemental modestia, tengo que contar parte de la historia de mi propia vida en unos escasos párrafos. Antes de empezar, quiero que sepan que el profesor Sarrat fue quien guio mis pasos desde que comencé a estudiar, y que siempre me ha servido de guía y ejemplo en mi quehacer cotidiano y mi ética vital.

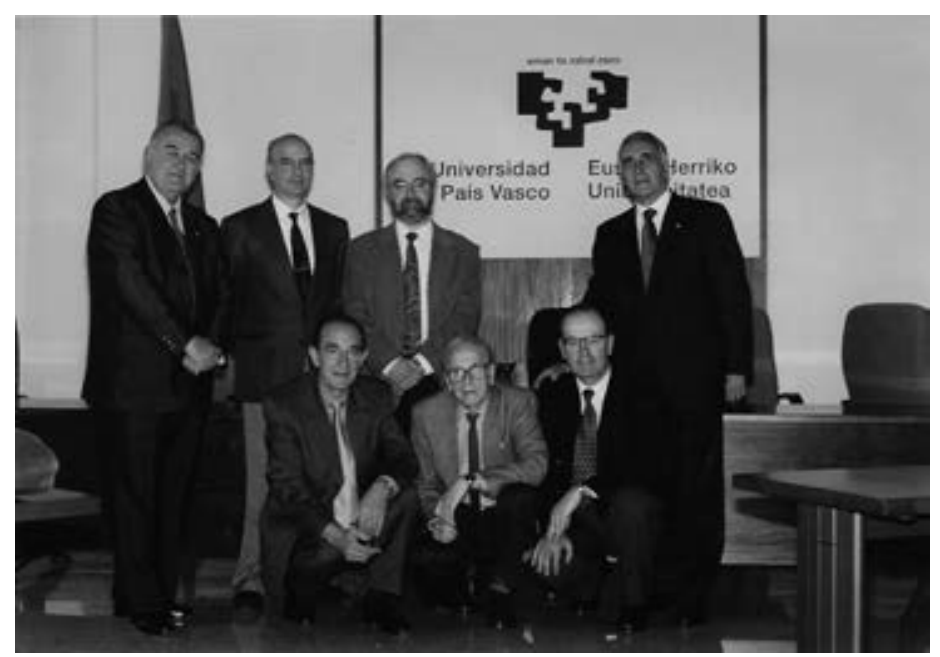

J. Méndez, F. Ainz, J. Rivera, L. Casis, J. M. Gandarias, J. Goiriena y R. Sarrat 
Inicié mis estudios en Medicina en el curso 1973-74, en la por aquel entonces denominada Universidad de Bilbao. Pertenezco a la sexta promoción de Medicina, también conocida como la promoción del «año Juliano», que se caracterizó por comenzar el curso el día 10 de enero de 1974 y acabar precipitadamente en julio del mismo año. Por aquel entonces estábamos ansiosos de entrar en la universidad, y esperábamos que llegara ese día desde mediados de octubre; buscábamos en los periódicos «la noticia» del comienzo del curso académico; por fin llegó el anhelado momento y leí y recorté con ilusión el anuncio, que, para mi sorpresa, era una pequeña reseña en la columna derecha del periódico, que aún conservo.

Al fin llegó ese deseado incipit y nos dispusimos a subir a la Facultad, situada en Lejona en medio de la nada, algo que sigue más o menos igual a día de hoy. Las clases comenzaban a las ocho de la mañana, así que poco antes de las siete ya estábamos un gran número de alumnos apiñados en Las Arenas en la parada del autobús. No todos los días teníamos la suerte de poder acceder a este medio de transporte, así que la mayor parte de ellos había que subir andando o haciendo «auto-stop».

No puedo borrar de mi memoria la primera clase de Anatomía a las ocho de la mañana en el anfiteatro. Éramos unos 1200 alumnos en total, 600 en cada grupo. Nos sentábamos tres alumnos en cada dos asientos, llenábamos las escaleras, que eran aposentos muy cotizados, y los últimos en llegar no tenían otra opción que sentarse en la tarima, rodeando al profesor, que apenas disponía del mínimo espacio vital para moverse durante el desarrollo de la clase.

En efecto, a las ocho en punto entró el profesor de Anatomía, el profesor Sarrat. Nos miró a las caras meticulosamente casi uno a uno, y se hizo un profundo y respetuoso silencio. Empezó la clase explicando qué era la Anatomía y algunos conceptos generales sobre la misma, continuando con el primer tema de embriología: «Este profesor tiene algo especial que aún no sé explicar bien. Tiene un fuerte carácter y se nota que le gusta lo que hace» - pensé para mis adentros. Salimos de clase con la extraña pero agradable sensación de tener todo aprendido; él hacía que el proceso de transmisión del docente al discente pareciese fácil. Cuando nos daba clase, sentía una mezcla de ilusión y tensión, eso sí, mezcladas con un poco de miedo. Sabía crear un ambiente especial en el aula. Ya en aquella época tuve la sensación de que todo lo que decía y dibujaba en la pizarra estaba minuciosamente calculado para conseguir nuestra atención y para hacer fácil lo difícil. Para el profesor Sarrat soy la alumna del «cuadernito», porque todas las dudas que me surgían al estudiar las apuntaba en un cuadernito para, después, ir a preguntárselas. Un buen día, tras haber acumulado un buen número de cuestiones, y lo suficientemente rebuscadas, me armé de valor y decidí acudir al despacho del catedrático de Anatomía. Llamé a la puerta y, para mi sorpresa, me recibió con una sincera atención y contestó amablemente a todas mis dudas. A partir de aquel momento, algunas compañeras mías se dispusieron a hacer lo mismo, esas alumnas son mis amigas Carmen Cavada Martínez y Carmen de la Hoz Torres. En fin, desde aquel primer contacto, convertimos este 
protocolo en un hábito tan frecuente, que creo que empezamos a suponer para él un verdadero martirio. En cambio, el profesor Sarrat nos recuerda hoy en día con cariño como las del cuadernito.

Entre clases teóricas y prácticas transcurrió aquel atípico primer curso y, tras no pocos esfuerzos, pasamos al segundo. Al comenzar este, mi amiga Carmen Bilbao y yo habíamos oído hablar de que en algunos departamentos necesitaban alumnos internos, así que no nos lo pensamos dos veces y un buen día nos presentamos en el despacho del profesor Sarrat para ofrecernos como internas del departamento de Anatomía. Nos puso a prueba durante unas semanas, así que nos pusimos manos a la obra concienzudamente. Como alumna interna, tuve la oportunidad de conocer el funcionamiento de un departamento en todos los entresijos de sus labores docentes e investigadoras. Entre las nuestras, estaba la colaboración en la obtención y elaboración del material de investigación para las tesis doctorales que el profesor Sarrat estaba dirigiendo en ese momento. Poco a poco, nos fue introduciendo en el mundo de la investigación, dedicándonos su tiempo con gran generosidad, porque acudíamos incluso algunos sábados, y nos enseñaba a reconocer las estructuras de diferentes tejidos al microscopio. En el laboratorio contábamos con una gran maestra en las técnicas histológicas, Ana María Torres del Puerto, su mujer, quien con gran paciencia nos inculcó paulatinamente todo su pragmático saber. A lo largo de aquellos años, compaginando mis estudios con las labores de alumna interna, fui recogiendo el material para mi tesina de licenciatura que defendí el año 1979, dirigida por el profesor Sarrat, e igualmente para mi posterior tesis doctoral.

\section{La etapa canaria en Las Palmas}

Al acabar el sexto curso de la licenciatura en julio de 1979, a René le propusieron el contrato como catedrático de Anatomía en el CUM (Colegio Universitario de Medicina) de Las Palmas de Gran Canaria. A Javier González y a mí nos ofreció generosamente ir con él y su mujer a la afortunada isla de Gran Canaria como Profesores Ayudantes de clases prácticas. Y por supuesto que fuimos afortunados; supuso un gran paso para mí porque conllevaba dedicarme a la docencia sin haber tenido experiencia clínica. Esto suponía tomar una gran decisión, así que, después de meditarlo unos días y consultarlo con mis amigos más allegados, decidí partir hacia las islas y aprovechar la oportunidad que mi maestro me brindaba.

Aquí comenzó una nueva etapa de nuestra vida. En septiembre ya estábamos en Las Palmas con René, Ana y su hija de tres años, Rebeca. Comenzó la planificación del nuevo curso, el profesor Sarrat hizo el reparto de las clases teóricas y prácticas de Anatomía I y Anatomía II. La Universidad de La Laguna nos concedió la venia docendi que nos permitía impartir las clases teóricas. 
Al preparar mis clases, descubrí otra faceta del profesor Sarrat, la de «formador de profesores». Nos supervisaba las clases escritas y los dibujos que debíamos hacer. Nos corregía no solo el contenido, sino el orden que resultaba más didáctico y el número de conceptos fundamentales que un alumno es capaz de asimilar, e intentaba inculcarnos cómo ser capaces de mantener la atención del auditorio en todo momento -él lo llamaba tener a los alumnos en la mano- y así conseguir que participaran y disfrutaran de cuanto les era transmitido. Era absolutamente imprescindible tener todo calculado a la hora de preparar la clase y también a la hora de impartirla. Él nos decía que una clase es como una obra de teatro; somos como actores y tenemos que captar la atención y convencer a nuestro auditorio. Así nos enseñó a elaborar primero un guión con los puntos clave de la clase: una introducción al tema, el desarrollo y un repaso o recapitulación final, a modo de rememoración de los puntos fundamentales. Al llevar los dibujos a la pizarra, hay que tener calculado dónde se hace cada uno, sus proporciones, que su tamaño resulte visible desde todos los puntos del aula, los colores que se utilizan en cada momento; así, los dibujos principales se deben hacer en el centro y los secundarios a los lados; nunca se debe borrar un dibujo, y ante todo, todo lo que se haga tiene que tener un claro objetivo. El profesor, cuando dibuja, tiene que hablar y explicar lo que está dibujando sin tapar con su cuerpo el dibujo y hablando siempre hacia el auditorio, lo cual dificulta la realización de los dibujos y esto supone que el docente ha de aprendérselos minuciosamente. Para ello, pasábamos interminables tardes dibujando en la pizarra.

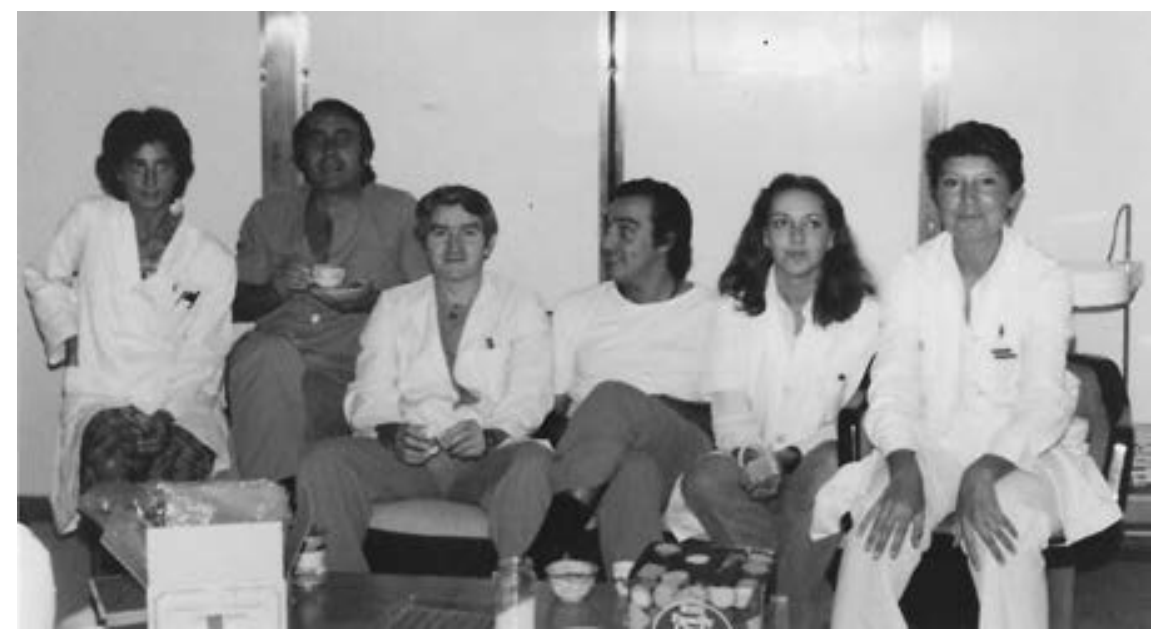

Leonor Hennequet, René Sarrat, Víctor Pérez, Javier González, Ana Torres y Carmen Pizarro Colegio Universitario de Las Palmas de Gran Canaria 
Y así llegó la puesta en escena, el primer día de impartición. El profesor Sarrat asistía religiosamente a todas las clases, pero no como un mero espectador, sino como un «director de escena». Se sentaba en la parte superior del aula para comprobar si nuestra vocalización y volumen de voz eran los adecuados, y si se escuchaba y entendía cuanto decíamos. Si era preciso, nos hacía señas desde arriba, como el más celoso de los entrenadores de un equipo deportivo, indicándonos que habláramos más fuerte, o más despacio, y se empezaba a incomodar y a hacer gestos de bostezo si se aburría. En ese momento, sabíamos que debíamos hacer algo, eso indicaba que los alumnos se estaban aburriendo y se nos iban de las manos, así que había que romper de alguna manera con la monótona escena, contar un chiste, caerse al suelo o enfadarse, pero era absolutamente necesario volver a captar la atención de nuestros pupilos.

Al acabar la clase, era la hora de hacer balance; acudíamos a su despacho, donde ya esperábamos la dura crítica que inexorablemente se avecinaba. Era fácil fallar en algo: el contenido, la forma, el tamaño del dibujo, el grosor del trazado con las tizas, la puesta en escena, la utilización de recursos, la atención del alumnado, etc. No se le escapaba nada, e intentaba que cada vez lo hiciésemos mejor. En fin, como verán, tuvimos la gran suerte, que muchos hubieran deseado, de que reparara en nosotros un gran maestro, una persona de una gran talla científica y humana que estaba dispuesto a revelarnos todos los secretos que entraña ser un buen docente.

Durante esos dos cursos académicos en Las Palmas, no todo fue trabajo, también compartimos grandes momentos de ocio y vida en familia. Sí, he dicho familia, porque René y Ana no solo se encargaron de mi formación académica, sino que me acogieron en su casa como un miembro más y me otorgaron todo su cariño y comprensión.

\section{Epílogo}

A día de hoy, debo confesar que todo cuanto he expuesto en este breve escrito perdura en mi interior. El sentimiento de admiración hacia un hombre de la talla de René va más allá de su valoración académica, algo que, a veces tan absurdamente, se intenta cuantificar en las normas de calidad que actualmente nos invaden. Siempre habrá algo no cuantificable, no medible, porque la verdadera dimensión humana de René no encaja en superficiales teorizaciones o valoraciones rudimentariamente aritméticas. Es necesario trascender más allá de lo vulgar o lo cotidiano para entender la auténtica dimensión de este hombre, algo que no se mide con simples baremos, sino con el afecto y la amistad continuados a lo largo de tantos y tan entrañables años.

Muchas gracias, Profesor, por ser mi eterno Maestro. 


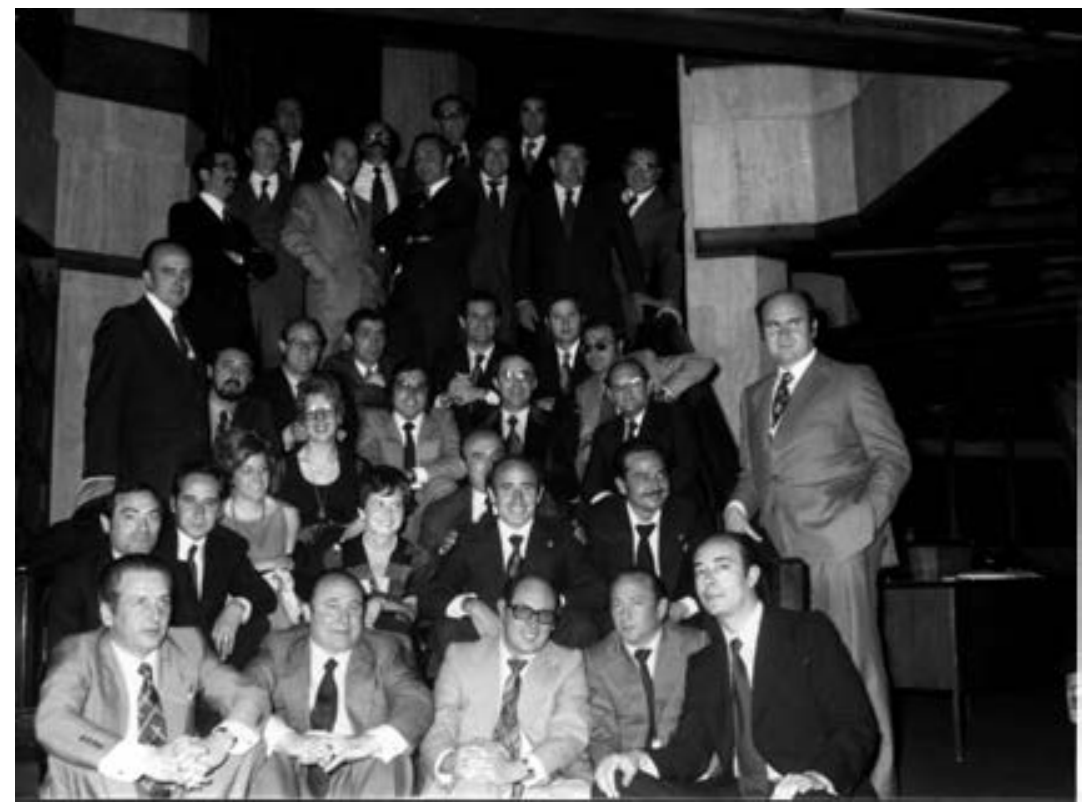




\title{
EN RECUERDO Y AGRADECIMIENTO AL PROFESOR RENÉ SARRAT
}

\author{
M. - Pilar Díaz Herrera
}

Profesora Titular de Anatomía Humana. Facultad de Ciencias de la Salud.

Universidad de Las Palmas de Gran Canaria

Un doble sentimiento de emoción y agradecimiento me embargó al recibir la invitación del Departamento de Anatomía e Histología Humanas de la Universidad de Zaragoza, para participar en el libro homenaje que se ofrecerá al profesor don René Sarrat Torreguitart con motivo de su jubilación. Emoción porque, al recordar, se reviven, con especial intensidad, muchísimos momentos compartidos con don René, no en vano han pasado 26 años, ser humano excepcional que siempre me ha mostrado gran cariño, me ha incluido en su entorno familiar y es uno más en el mío. Agradecimiento al maestro que ha sido el determinante de mi discurrir profesional; la docencia y yo nunca nos hubiéramos encontrado de no ser por él. A su vuelta a la Universidad de Zaragoza, me

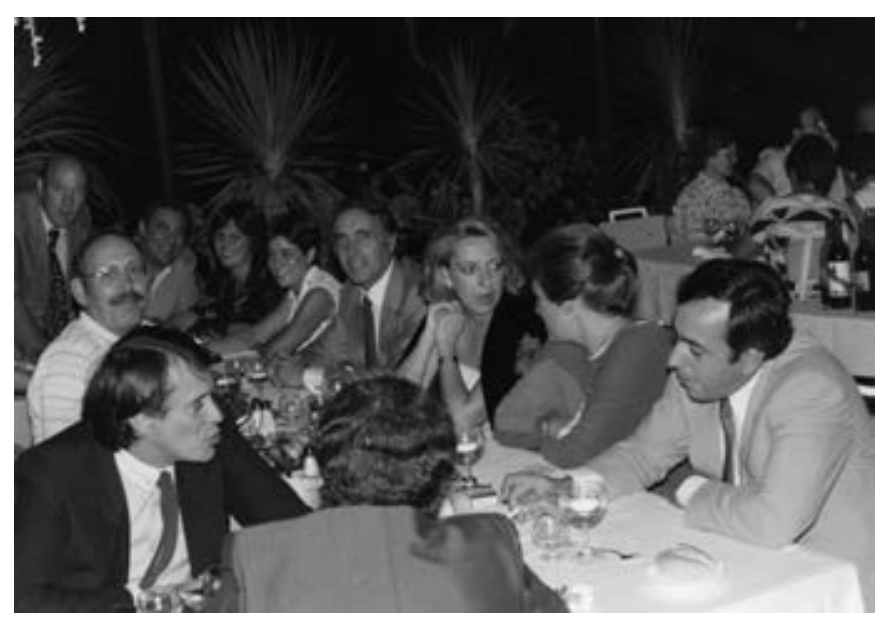

Gerardo Garcés (espaldas), Paco Rubio, Isidoro Río, Macario Martínez, Carlos Corral, Encarnación Castellano, Encarnación Palomino, René Sarrat, Ana Torres, Évora y Pedro Betancor 
abrió las puertas del departamento, donde todos me acogieron como una más y compartieron conmigo su experiencia, tutelando mis primeros pasos como docente. El honor que me han hecho al invitarme a participar en este libro homenaje, atestigua el mutuo afecto y la amistad que me une a ellos y que no quiero dejar de reflejar en estas líneas.

No soy la única, entre sus alumnos del entonces Colegio Universitario de Las Palmas (CUPL), que lo consideran culpable directo de su vocación docente, que hoy desarrollan en distintas disciplinas dentro la Universidad de Las Palmas de Gran Canaria (ULPGC). Comentando con ellos y con compañeros que compartieron con él la docencia de medicina en aquellos días del CUPL, nos pareció este libro homenaje una oportunidad única para reflejar la importancia del profesor Sarrat en la consecución del proyecto de ULPGC y el legado académico y científico que nos dejó.

Cuando a finales del curso 1977/78 llegó al CuPL, lo recibió un aula llena de alumnos expectantes, recelosos tras tres años de difícil relación con la Anatomía que culminó con la salida del anterior profesor. Difícil auditorio que, minutos después de iniciarse la clase, había rendido las armas. La Anatomía que apareció ante nuestros ojos se desarrollaba mediante una sucesión de dibujos sencillos, que nos mostraban a través de la Anatomía Comparada y la Embriología, las bases de la organización del sistema nervioso. Al final de la jornada resolvimos: «nos lo quedamos»; por fortuna, como el siempre cuenta, al volver a casa dijo a la familia, «nos vamos a Gran Canaria».

Desde ese momento y hasta finales del curso 1982/83, la Anatomía que disfrutamos de la mano del profesor Sarrat, representó una auténtica innovación pedagógica. A esa exposición sencilla pero brillante a la vez, donde no había un concepto ni una imagen de más, se unía una orientación funcional y una aplicación a la clínica que nos era nueva. Muchos gestos de entonces, no dedicados a ningún otro profesor, son prueba de nuestro reconocimiento. Así, durante esos años, no faltar a clase de Anatomía era cuestión de honor; los alumnos pedían disculpas cuando, siempre por causa de fuerza mayor, habían faltado a clase. Que se marchara sin decir palabra del aula, cuando no se respondía alguna cuestión que debía saberse, generaba tal sentimiento de culpa que, espontáneamente, derivaba en una disculpa inmediata transmitida por el delegado del curso y, al día siguiente, se dominaba la materia como si hubiera examen. Asimismo, era habitual ver los últimos bancos del aula ocupados por estudiantes que ya habían superado la asignatura y por médicos del vecino Hospital Insular, que acudían a sus clases. «Ahora sí que lo comprendo», era una frase habitual entre sus alumnos ya licenciados.

La trayectoria académica del profesor Sarrat durante estos años no se limitó a la docencia de pregrado. Desde el principio desplegó una notable actividad investigadora, introduciendo varias de sus líneas de trabajo que permitieron comenzar o retomar la investigación, a nuevos licenciados y a médicos que ya desempeñaban actividad asistencial en distintos centros de la isla. Como ocurrió con la docencia, analizado en el tiempo, destaca lo novedoso de algunos de los temas abordados, que anticipaban aspectos médicos hoy de plena vigencia, pero que entonces iniciaban su desarrollo o incluso se les negaba un carácter plenamente científico. Ejemplo de ello, la acupuntu- 
ra, sobre la que hoy las universidades ofertan másteres y los colegios médicos arropan a profesionales dedicados a esta disciplina milenaria, validando así su utilidad. Pero, a comienzos de los años ochenta, cuando se desarrolló la tesis doctoral de la doctora María José Murillo, esto era impensable. Aún recuerdo las dificultades de ambos para conseguir entrevistarse con los directores de los escasos gabinetes de acupuntura de la isla. Pese a ello, abordaron el tema con rigor científico y efectuaron un detallado estudio de las singularidades histológicas de los puntos cutáneos en los que se aplican las agujas de la acupuntura.

Con motivo de la tesis doctoral del doctor Jaime Núñez, urólogo, se abordó, a nivel experimental, el efecto de la vasectomía sobre el aparato genital masculino. Cirugía entonces polémica por doble motivo: médico, al relacionarse con el cáncer genital y con la patología ateromatosa sistémica; y ético, ya que 30 años atrás, un considerable porcentaje del colectivo sanitario no simpatizaba con este procedimiento anticonceptivo. De ello da fe la dificultad que siempre había a la hora de conseguir los proyectos de investigación que se solicitaban; con frecuencia, los motivos académicos no eran determinantes a la hora de su admisión.

Igualmente enlazada con la cirugía experimental, la línea de estudio referida al aparato locomotor. Puesta en marcha para las tesis doctorales del doctor Gerardo Garcés y de la doctora Elvira Santandreu, mediante ella se estudiaron los efectos denervación sobre distintos componentes del aparato locomotor, o la eficacia de distintos fármacos sobre los callos de fractura. De este legado se han beneficiado numerosos traumatólogos y rehabilitadores de nuestra isla, que han continuado estos trabajos y han obtenido, con ellos, sus tesis doctorales y numerosas publicaciones.

Nuevamente, es una colaboración con clínicos, en este caso el doctor Maynar Moliner, radiólogo vascular intervencionista, la que da inicio, en el CUPL, al estudio sobre la relación entre las variaciones en la estructura de la pared arterial y la mayor incidencia de la aterosclerosis, en determinados segmentos vasculares. Resultado de ella, no solo la tesis doctoral del doctor Maynar, mi tesina de licenciatura y tesis doctoral, sino toda mi actividad de investigación que, dirigida por el profesor, he podido desarrollar junto a quienes son más que compañeros, mi familia aragonesa, Ana Torres y Jaime Whyte. No puedo dejar de referirme, en relación a esta línea de investigación, al honor que tanto el profesor Sarrat como Ana me hicieron al invitarme a codirigir con él la tesis doctoral de su hija Rebeca.

Si bien es menos emotivo y desinteresado que el hecho de que los alumnos y compañeros te consideren un maestro, no hay prueba más contundente de la valía y de la necesidad de contar con una persona, que el hecho de que un político te ofrezca un cheque en blanco para intertar retenerte. Eso ocurrió, de la mano de don Juan Jiménez, entonces Presidente del Cabildo Insular de Gran Canaria, cuando el profesor Sarrat le anunció que, tras el final del curso 1983/84, dejaría el CUPL para incorporarse a la Universidad de Zaragoza. 
Obviamente, fue una oferta posibilitada por su prestigio académico, demostrado antes y durante su estancia en el Colegio Universitario; pero, sin duda, fue el reflejo de la necesidad que teníamos de contar con su excelencia académica, para llevar a buen puerto la lucha por la consecución de la Universidad de Las Palmas. Se implicó como un gran canario más en esta lucha. Antes de su llegada contractual, nos hizo el favor, sin conocernos, de impartirnos la docencia de la Neuroanatomía, evitando que la Universidad de la Laguna nos negara la venia docendi, a la marcha del anterior profesor. $\mathrm{Su}$ «fichaje» por el CUPL y la labor desarrollada entre los cursos 1978/79 a 1982/83, fue un refuerzo clave para la plantilla del centro; nos dio a conocer, en positivo, en otros distritos universitarios, obviamente presentes en las instituciones nacionales que habrían de dar luz verde a la creación de la universidad. Como un auténtico «canarión», participó en la masiva y decisiva manifestación que la población realizó para exigir la universidad. También como uno más sufrió los despropósitos de la Universidad Lagunera de aquellos días. A menudo he oído al profesor referir cómo, cuando acudió a la apertura del curso académico en La Laguna, el año de su llegada, al saludar a algunos docentes a los que le unía muy buena relación, no los mencionaré, y decirles que se incorporaba al CUPL, palidecieron, quedaron mudos y huyeron en retirada. Sobra decir que no volvió.

No nos sorprendió su marcha; la cátedra de la Universidad de Zaragoza, donde se formó como médico y como profesor, de la mano de maestros como don José Escolar, le era muy querida. Añadido a esto la posibilidad de estar junto a su familia y el incierto futuro del CUPL, que obligaba a optar por las plazas vacantes de la universidad oficial. Ninguna oferta podría contrarrestar estas circunstancias.

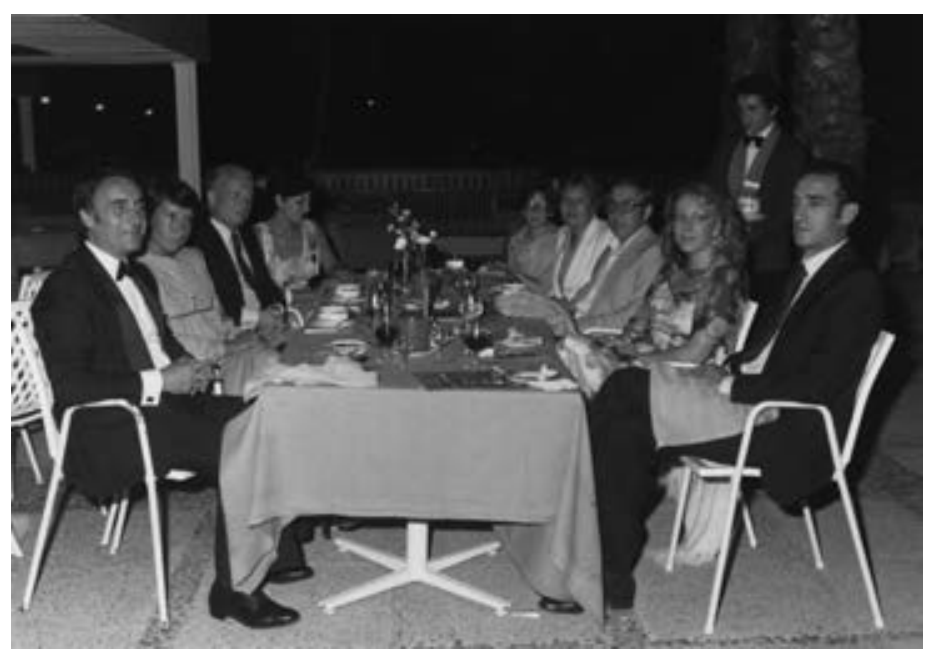

René Sarrat, Carmen Pizarro, Patricio Valverde, Inela, X, Inmaculada, Ricardo Bahamonde, Ana Torres y José M. ${ }^{a}$ Rivera 
Quiero terminar estas líneas transmitiendo al profesor Sarrat el cariño, la admiración y el respeto, de los que le hemos tratado, como alumnos o como compañeros, en el antiguo CUPL, hoy Facultad de Ciencias de la Salud de la Universidad de Las Palmas de Gran Canaria. Cada vez que surge su nombre en nuestras conversaciones, y ocurre muy a menudo, queda patente que René Sarrat Torreguitart es, en el terreno profesional, profesor irrepetible de Anatomía Humana y maestro único del saber y, en el personal, su trato y calidad humana quedan para siempre en nuestros corazones.

Laudamos tuam scientiam, maestro.

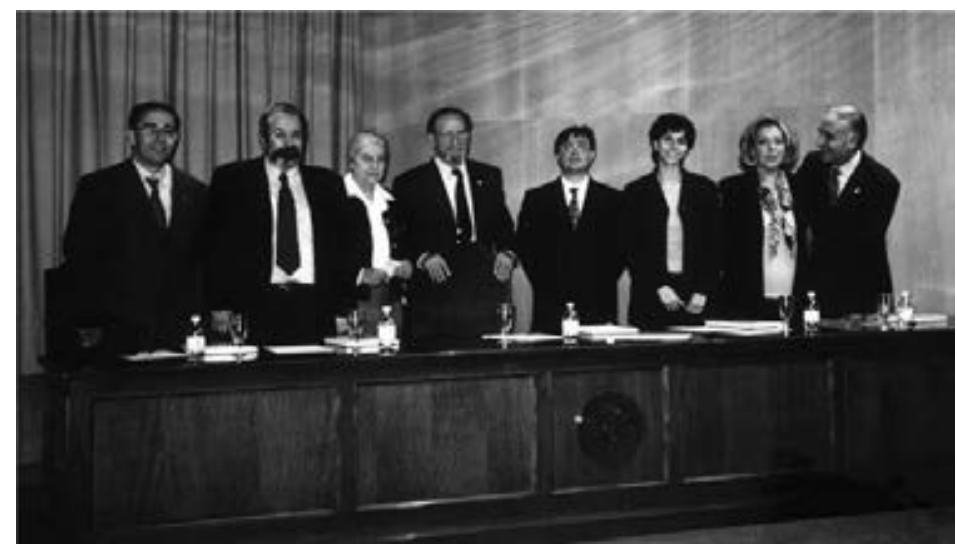

Jaime Whyte, Alberto Tierz, Inés Fernández, José M. ${ }^{a}$ Smith,

Raúl Pérez, Pilar Díaz, Ana Torres, René Sarrat 


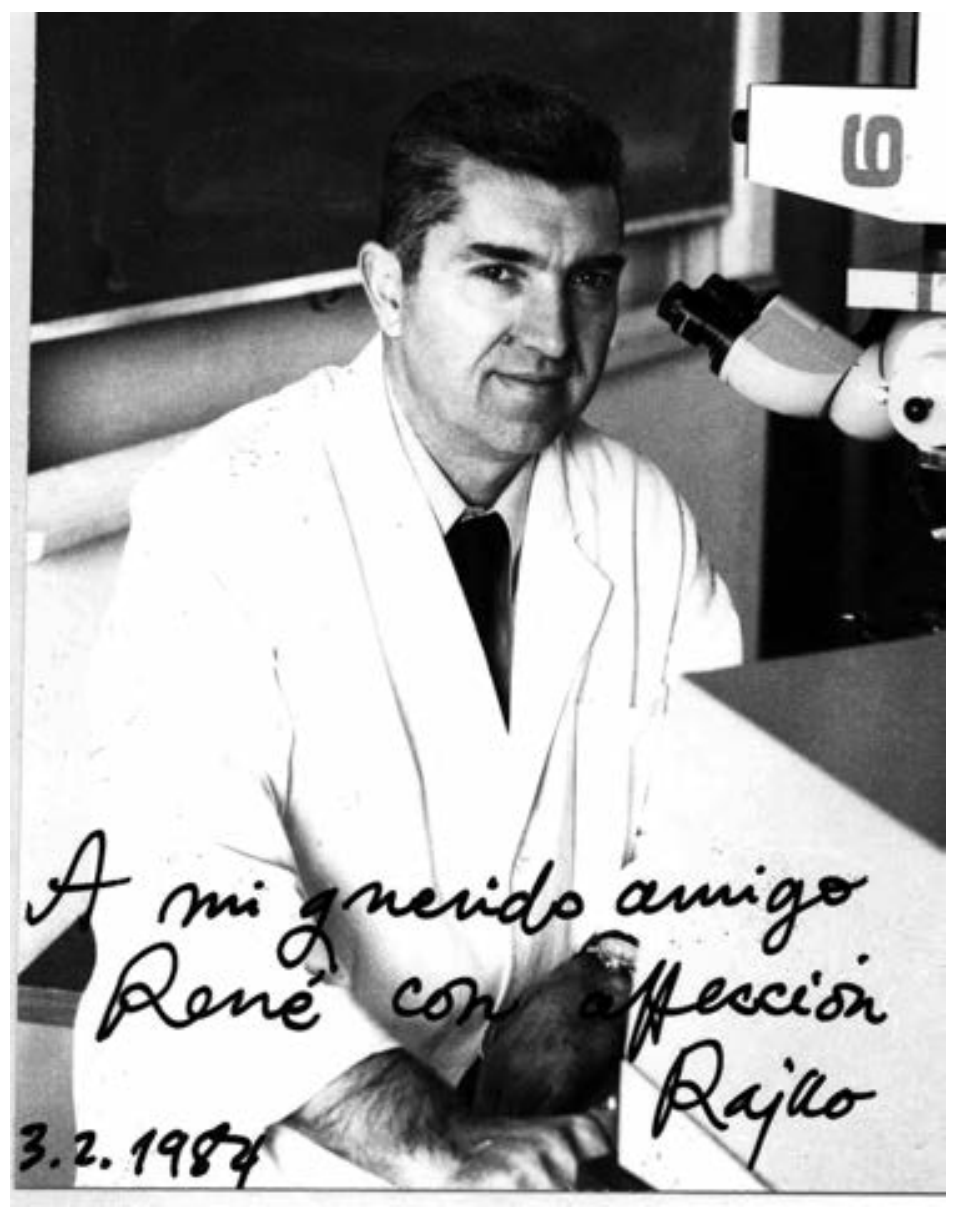




\title{
AL PROFESOR RENÉ SARRAT
}

\author{
Carmen Cavada
}

Catedrática de Anatomía y Neurociencia. Presidenta electa de la Sociedad Española de Neurociencia Directora del Departamento de Anatomía, Histología y Neurociencia

Facultad de Medicina. Universidad Autónoma de Madrid

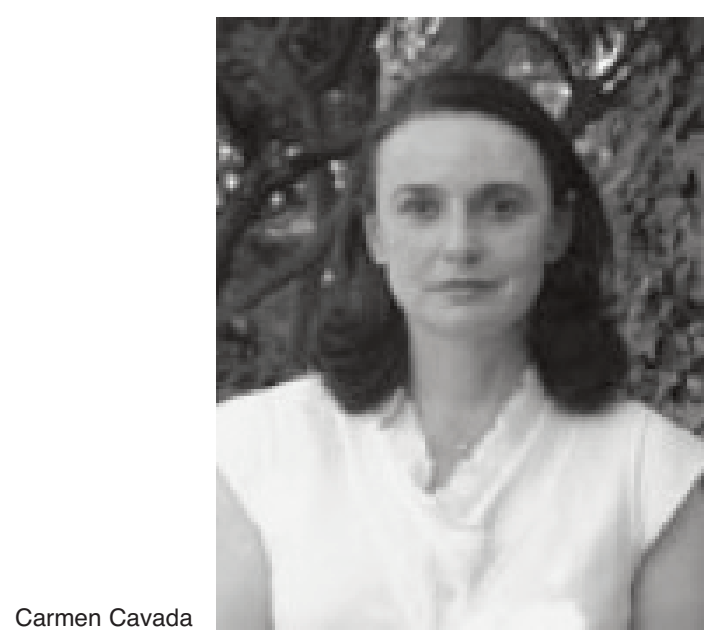

Querido profesor Sarrat:

Sus compañeros de Zaragoza me invitan a escribirle con motivo de su jubilación. $\mathrm{Su}$ iniciativa es para mí un regalo pues me hace poner negro sobre blanco cosas que, posiblemente, no me hubiera decidido a decirle por timidez o por no saber encontrar la ocasión.

Le conocí un día de enero de 1974 en el gran anfiteatro de la Facultad de Medicina de la entonces llamada Universidad de Bilbao. Aquella primera clase de Anatomía es el primer recuerdo de mis estudios de Medicina. Usted era nuestro profesor. En el estrado, con el anfiteatro repleto de centenares de estudiantes, seguramente más de mil, esperó pacientemente a que reinara un silencio absoluto.

Empezó, así, a explicarnos la primera clase de Embriología; recuerdo claramente la primera palabreja que anoté sin entender: «teratógeno». Uno de aquellos primeros días, pocos minutos después de iniciada la clase, alguien entró por la puerta del piso superior. Usted paró la explicación, nos explicó que era nuestra obligación acudir puntualmente a clase y no interrumpirla entrando fuera de hora o de cualquier otra manera; y para subrayar la importancia de lo dicho se marchó, advirtiéndonos antes que esto es lo que ocurriría siempre que interrumpiéramos la clase. Aquella masa de alumnos desnortados 
aprendió rápidamente la lección. Gracias a su capacidad docente y a nuestra aprendida disciplina, todas las clases de Anatomía, tanto en primer curso como en segundo, fueron modélicas. Creo que nunca he asistido a una clase en que reinara tanto silencio y ambiente de trabajo como en aquel atestado anfiteatro durante sus clases de Anatomía. El anfiteatro nunca dejó de estar repleto; los alumnos nos reservábamos el sitio de antemano para poder ver de cerca la pizarra (aquello me costó unos cuantos paraguas, me quedé sin ellos y sin el sitio que reservaban), colocábamos carpetas entre dos asientos para hacer más sitio y, cuando todo esto fallaba, que era lo habitual por ser tantísimos alumnos, nos sentábamos tan contentos en las escaleras o en el suelo. Lo importante era no perderse una clase de Anatomía. Antes de comenzar la clase, Usted ordenaba cuidadosamente las tizas que utilizaría y los borradores, incluyendo una bayeta amarilla; y luego se dedicaba a observarnos mientras nos sentábamos y esperaba a que se hiciera silencio. Este pequeño rito del comienzo de cada clase lo recuerdo con especial claridad; creo que revela el profundo respeto y amor que ponía en su docencia y en sus alumnos, respeto y amor que impregnaban sus clases. Estas eran un disfrute para los estudiantes ansiosos de aprender, porque Usted lo hacía posible: explicaba con orden y claridad, hacía unos dibujos excelentes y, sobre todo, ponía todo su empeño en ello. Nos transmitía que valía la pena estudiar tantos nombres y detalles porque queríamos ser médicos; además, nos enseñaba a disfrutar de la Anatomía y de la Medicina porque eran bellas, apasionantes en sí mismas. Esto último fue especialmente claro para mí, en segundo curso, durante el estudio de la Neuroanatomía. De hecho, su magisterio en conjunto, y sus clases de Neuroanatomía en particular, condicionaron todo mi quehacer profesional. Déjeme que lo recuerde.

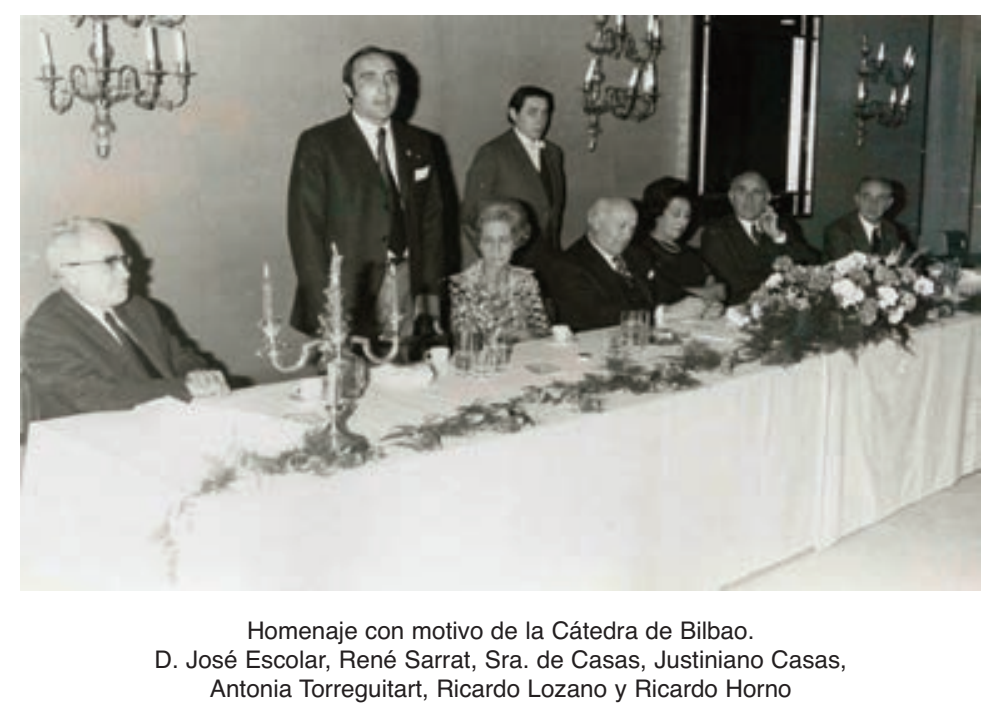


En segundo curso, a raíz de sus clases de Neuroanatomía, empecé a pensar que el sistema nervioso era lo más apasionante de la toda la biología y la medicina humana. Esta convicción fue afianzándose durante la carrera y es más firme cada día que pasa. Recién terminado el último curso, acudí a Usted para hablar de mi futuro profesional. Aquella fue nuestra última conversación en Lejona, justo antes de su desplazamiento a Las Palmas de Gran Canaria y de mi viaje a Kochel am See para hacer un curso de alemán que Usted mismo había tomado en su día y que me había recomendado y facilitado. En aquella conversación no me orientó hacia ninguna senda en particular pero me dio el mejor de los consejos utilizando un símil que me dijo le venía de su afición de cazador: «atiende a tu olfato y toma el camino que te indique». A mi regreso de Alemania tenía claro que quería hacer una tesis doctoral sobre el sistema nervioso. Pero como no tenía ni idea de por dónde empezar, de nuevo acudí a Usted, que, ya telefónicamente desde Las Palmas, me aconsejó que viajara a Madrid y hablara con el profesor Fernando Reinoso Suárez. De esta forma, inicié una trayectoria profesional, centrada en el estudio del sistema nervioso de primates, y en la docencia de Anatomía, que ha aportado una riqueza fundamental a mi vida. Por ello estoy profundamente agradecida.

Estos recuerdos quedarían incompletos y limitados a simples anécdotas si dejara de manifestar la altura de miras y la generosidad que guiaron su relación conmigo. Ningún testimonio lo dejará más claro que una carta que Usted me envió en 1981, en respuesta al envío que le hice de mi primera publicación internacional. Creo que me perdonará que viole una parcela de su intimidad y la haga pública copiándola al final de esta carta. Esa frase de la segunda página, «[...] desprenderme de ti y [...] no considerarme digno de continuar tu formación», encierra, en su humildad, la mayor grandeza de espíritu que un maestro puede ejercer.

Querido profesor Sarrat, GRACIAS por haberme enseñado a amar la Medicina y la Anatomía, a respetar la docencia en la universidad y a gozar con el estudio de nuestro sistema nervioso. GRACIAS, en particular, por su ejemplo de maestro generoso. Estoy convencida de que nunca dejará de ejercer ese magisterio en la forma que el futuro ponga a su alcance; por ello también le doy las gracias de antemano.

Un fuerte abrazo,

PS. Carta manuscrita firmada por el profesor René Sarrat Torreguitart, fechada el 3 de diciembre de 1981: 
62

CARMEN CAVADA

COLEGIO UNIVERSITARIO DE LAS PALMAS DIVISION DE MEOACINAI Aportado de Correos, 550
Las Palmas. 3-ticieubre-811

Queida Carmen!

Si puedes inafiutrte la ale fria que seuti al mecibir tus primeras separatas de tau prestifiosa revista, encabezadas por tu ardial dedicatoria. Eulworabuena!.

seguro fue a lo largo de este tiver. po Mabra's purado une dras veces que tus aras vau despacid; fue el trabajo ha dedicacim the unechas para el aporente escaso fruto de estís aús uniciales, is verdad; pero is despacio wo uno se debe ir, prypuc la velocidad foroduce eausaucio, turbulencia, astio, euorule riesso de equivocarte.

Estog snevercido de fuc estás en el buan camino de la Mraus de D. Fernalu. Lo 1 tu frupo; lo ívico fuc picuso cu ocatimes mando te oifo Matlar de cocurcia, 1 so me produce una cienta ustalifia, es fue $7^{0}$ te pute en tur manos por motivo de la investifacin' greo fue ali estä fu vida; la docencia eres fue la unhier anus hedes jurtos an fran eficacia.

Sé pue ticues fue lacer me poco to fue ancine al Dept-, fue ssa docercia aluatón 
AL PROFESOR RENÉ SARRAT

63

mica es un servicio, wha enetraprstacion fre ha fue realizar 2 fue de paso te unifuece; pero no olvides jaurás Isé pue te irál pronto "fuera", fie alli peusavás undero, que es Id Investipacin lew nstelua ke vioso, de ese polo frontal precis amente fue has anuen zado a "arauar", la fie podrá llevar fie vida; Me esa motivació fié lá úvica fre me avinno'? a desprenderure de $\hbar$, a wo cruiderarue difuo de cretimar tue formacion, prefinieudo fue furar Feruardo,

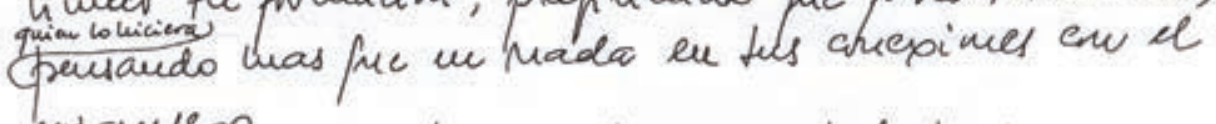
extraupero. Estop satisfecho de haberte viculcado un cariño Macia ese tuka tan apasionante, espero con arteza fue acatarás por vicortpororte a chud de los was prstifisos frupos acl unundo, trara fue derde alli, reatices tur sucieo de ver ve Peresso Hunawo bajis undes verticutes, induida por tupuesto la pattó. fica a nivel menidófics o pufruilatico fue jo ereo the the la untura cosa vista pur Lourbes de recurhs dife. reutes.

Wur furte asrats de Area g nio, pue uos aleframs tartilino de the avance.

Oordialmente!

Cordiales paludes as D. Teruaudo 8 cols.?

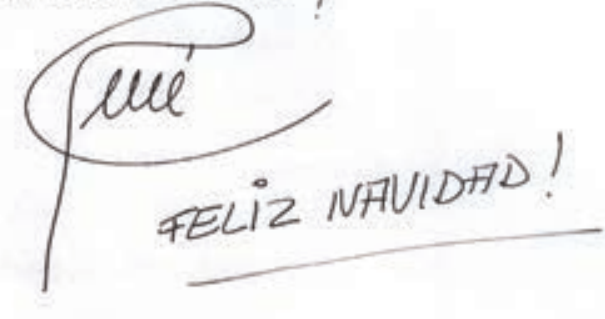




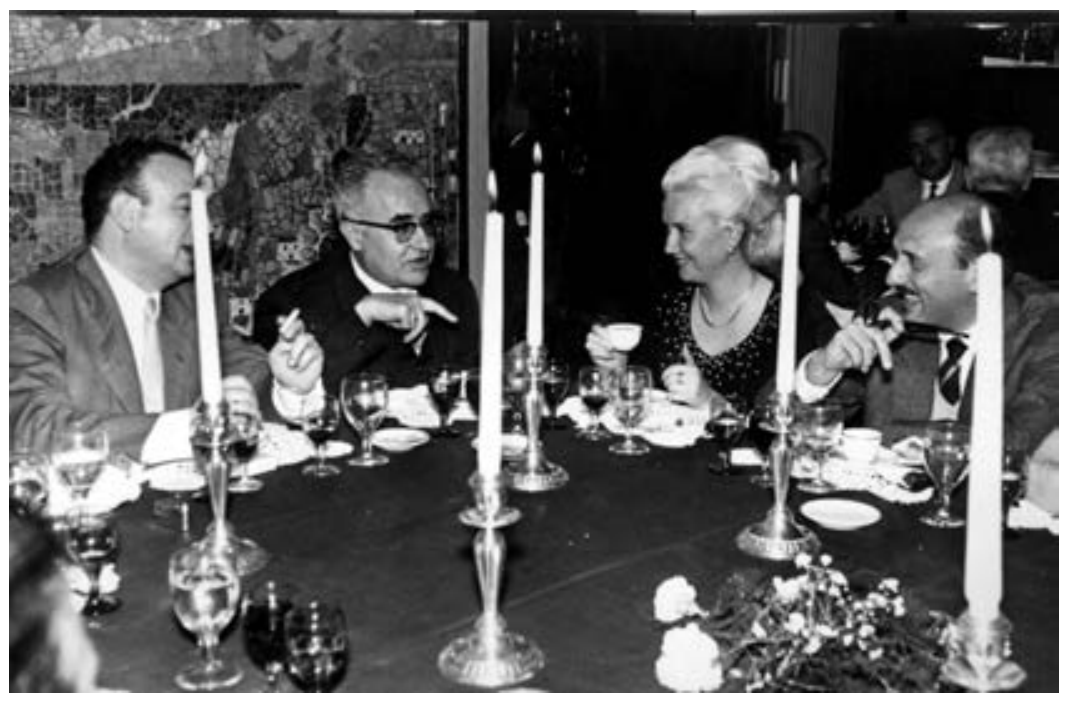




\section{LA GRAN LECCIÓN DE RENÉ SARRAT}

Vicente Calatayud Maldonado

Catedrático emérito de Neurocirugía. Facultad de Medicina de Zaragoza

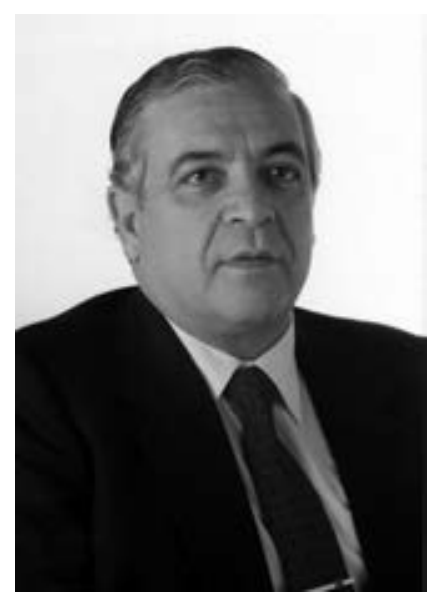

Una, para mí, feliz coyuntura de circunstancias, me proporciona el honor y la satisfacción de poder escribir del profesor René Sarrat Torreguitart. Estudiante de hoy y de ayer, compañero y amigo, con el que tuve el privilegio de recorrer caminos científicos, sociales, familiares y humanos, que hicieron posible que el afecto, el respeto y la admiración por un hombre íntegro se hicieran cada vez más fuertes con el paso del tiempo. Querido René: ahora escribo con el deseo siempre válido de sentirnos cada vez más jóvenes, recordando tiempos que hacemos actuales con inquieto espíritu renovador.

Hoy aquella realidad se hace corazón. Siempre admiré a aquellos que me enseñaron algo a lo largo de mi vida, fueron muchos y de las más variadas especies docentes. En la Misna, recopilación de la sabiduría judía, el Rabí Yeuda Ha Nahi dice: «Mucha ley aprendí de mis maestros, más aún de mis colegas, y de mis discípulos muchísimo más que de todos», y yo añado, «y de aquellos que tuvieron a bien confiar su salud en mis manos».

De ti aprendí en cualquiera de las categorías que indica el Rabí, como alumno, como compañero, como maestro y como paciente, ya que tuviste a bien encomendarme no solo tu salud sino la de muchos de tus seres queridos que, al conocerlos, entendí el porqué eres portador de cualidades, que te calificaban como humanista, como científico, pero sobretodo como ser humano en tu inigualable recorrido vital por estos páramos académicos. 


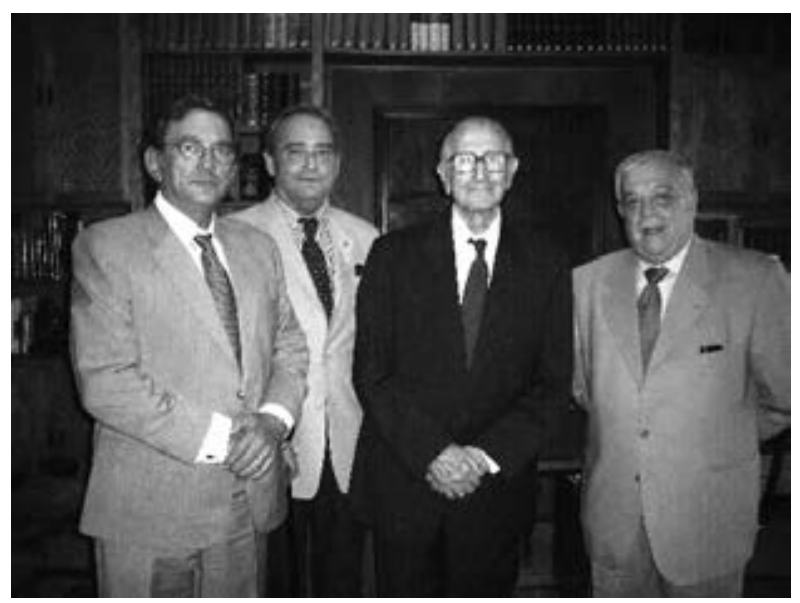

Profesores Barberá, Barcia Salorio,

Barcia Goyanes y Vicente Calatayud

Juntos vivimos esa sensación ambigua, todos aquellos que nos preocupamos por el estudio de las ciencias neurológicas. La impresión que nos produce el gigantesco aumento de nuestros conocimientos, se acompaña de la decepción profunda, al comprobar que es mucho lo que todavía nos queda por conocer. ¿Recuerdas aquellos tiempos que, como paupérrimos becarios, por la entonces dividida Alemania, intensamente vigilados por nuestro común maestro? ¿De aquel tiempo de constante inquietud científica donde cualquier hallazgo abría la puerta a nuevos problemas?

Aprendimos juntos, creo que tú mejor que yo, aquello de que no es consciente de lo que dice aquel que, con suma ligereza, se permite el lujo de afirmar que estamos a punto de conocer los secretos del cerebro, que vamos a penetrar en el pensamiento de otra persona. Esa ha sido tu gran lección. El continuo estudio de los mecanismos, no solo morfológicos sino funcionales de nuestro sistema nervioso. La preocupación constante por completar con dignidad el estudio de nuestro órgano supremo.

Cuántas veces, entre recuerdos ajenos a la ciencia, hemos dialogado sobre la posibilidad de que las nuevas tecnologías nos demuestran la implicación de muchas áreas cerebrales en el proceso mental. Maravilloso y tosco a la vez. Utilizábamos una metáfora lingüística; conocemos cada vez mejor la sintaxis del cerebro, pero no progresamos en el conocimiento de la semántica.

Coincidirás conmigo que la no aceptación precoz de estos avances, técnicos y docentes, ha sido, en parte, y en mi opinión, el fracaso de los planes de estudio en la enseñanza actual de la medicina.

Hoy podemos preguntarnos: ¿somos lo que contiene nuestro cerebro? El cerebro es un órgano de producción simbólica. Y un símbolo remite siempre a algo que está fuera del símbolo. 
La capacidad personal tiene un fundamento fisiológico, del que dependen nuestras características físicas e intelectuales. A partir de este nivel básico hemos de estudiar la personalidad humana en niveles distintos, cada uno de los cuales se libera en parte del determinismo biológico. El nivel más próximo a la biología es el temperamento.

Tú, como todos, nacemos con algunos rasgos determinados, que nos abren posibilidades y nos cierran otras. Es el aspecto más fijo de la personalidad, pero nuestra experiencia biográfica va determinando, reestructurando mediante el aprendizaje y la actividad, algunas de esas posibilidades, en ti inmensas, conformando el temperamento y la memoria, es decir, el carácter.

Sobre estos pilares has construido tu personalidad, que la has hecho patente cultivando tus capacidades temperamentales y caracterológicas. En este nivel han intervenido las valoraciones, los proyectos, los modelos culturales, los propios modelos, que empezaste a construir en Gimenells, después en Zaragoza, en Bilbao y por donde quiera que pasaste, dejando una aureola, con un perfume de universitario apasionado difícil de superar.

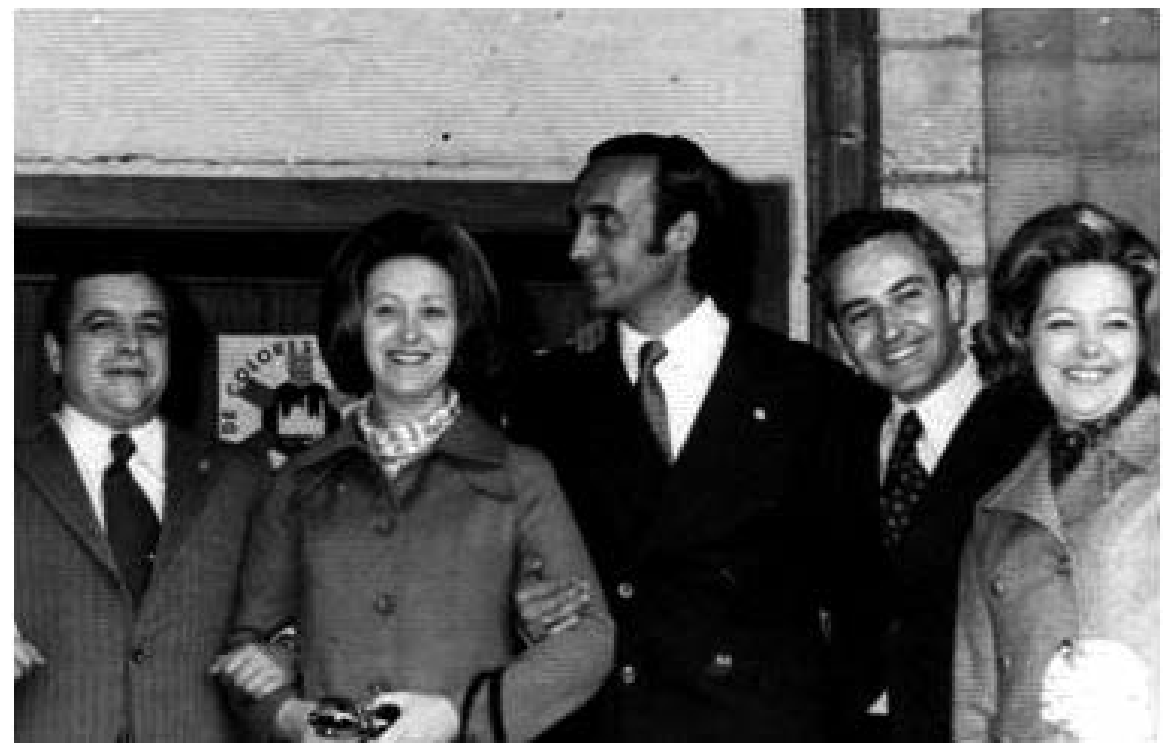

Vicente Calatayud, Sra. de Calatayud, René Sarrat, Santiago Rodríguez y Enriqueta

Hay científicos que creen que estamos completamente determinados por nuestro cerebro, negando con ello la libertad humana. Creo que están en un error. Un sistema inteligente consigue que, mediante procesos deterministas, pueda alcanzarse un comportamiento liberado de muchas cosas. 


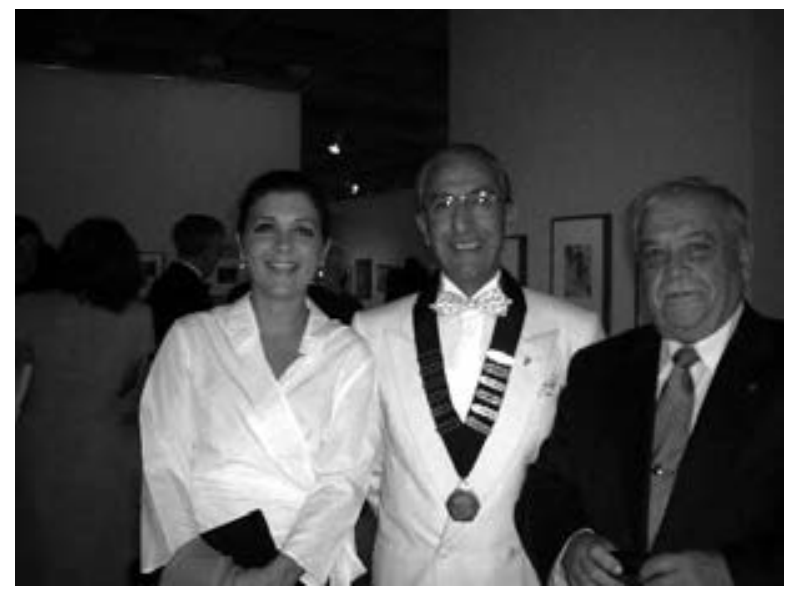

Dra. Calatayud Pinuaga, profesor Samii y profesor Calatayud Maldonado, en Australia

El profesor Sarrat se forma a sí mismo, forma a sus alumnos, y es fundador de una pedagogía en acción, la más sorprendente de las pedagogías, la conquista del ideal por dedicación y por una constancia y sacrificio que se basan en la prudencia, el sentido común, ennoblecido en su contacto con la llama viva de lo ideal. Su tierra, su Gimenells, tierra que respeta y siente propia porque en ella vio por primera vez la luz y por la que anduvieron sus antepasados, elogiada también por otra pasión de mi amigo René: la cinegética.

René Sarrat es el prototipo íbero, con una acusada característica: el saludable equilibrio de lo espiritual y lo material, que ha definido y diferenciado siempre la calidad y la eficiencia en su caminar universitario.

En el fondo su gran lección se basa en utilizar su buen sentido natural, aplicando la ponderación y la prudencia como premisas para elevarse a las regiones del espíritu; procurando antes de ascender, tocar firmemente la tierra, con la finura intelectual, la agudeza y vivacidad, la serenidad y la tenacidad de un español de Cataluña. Esa es la gran lección de mi amigo el profesor René Sarrat, hombre excepcional, de los que aparecen cada muchos años. Persona impactante, creadora e innovadora e inconformista con los métodos docentes de la época. Su fe en la universidad europea, constituía una pasión que puso en práctica y que parece ser que la verá hecha realidad desde los bancos de eméritos.

En René como en El Quijote, se describen hermosas y eternas ideas: el honor, la lealtad, la fidelidad y otras virtudes que constituían el ideal del caballero que siempre serán estimadas y queridas por los nobles de espíritu. 
Siempre ha manifestado inquietud, comprobándose su interés, por cualquier actividad de nuestra vida cotidiana, de nuestra sociedad, desde la política, la sanidad, la justicia, la universidad y la iglesia y desvelando en él, algo que interesa a la vida humana.

El doctor Sarrat era consciente, cuando empezó su andadura universitaria, de que todo lo que podía ganar en tranquilidad y en salud siguiendo la vida monótona, lo perdía en grandeza espiritual y que si no desarrollaba su vocación universitaria, su personalidad quedaría mutilada como semilla ejemplar.

Hoy, creo que, desgraciadamente, la imaginación, el esfuerzo y el sacrificio se sustituyen por la ambición y el poder.

Querido René: los verdaderos y emotivos vínculos adquiridos en la universidad se ponen de manifiesto cuando en el cruce de caminos, después de un tiempo separados, recibes un saludo, una palabra, de aquellos que fueron un día tus discípulos.

Espero que tengas la fortaleza de mantenerte siempre joven de espíritu, mantén siempre los anhelos, las ilusiones y los entusiasmos de nuestra época de estudiantes o de opositores. Esto solo se puede mantener en plena actividad, ahora leyendo, no estudiando, en el libro, en el enfermo y en las páginas de la vida, pues este estudio renovador es el que tonifica y rejuvenece. No permitas que bajo ningún concepto se extinga la afición al estudio y el amor a la universidad.

Tengo la seguridad de que siguiendo tus enseñanzas, tu gran lección de la vida, conseguiremos humanizar la tecnología y no perder de vista el humanismo.

Zaragoza. Septiembre de 2008.

Arriba: Profesores Danke, Bano

y Geletneky.

Sentados: Dr. González Arias, profesor Calatayud, Sra. profesor Lorenz y profesor Lorenz, en Japón

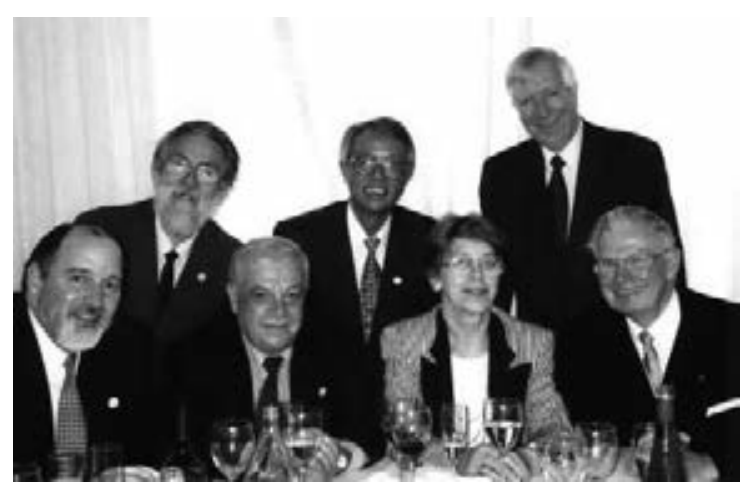




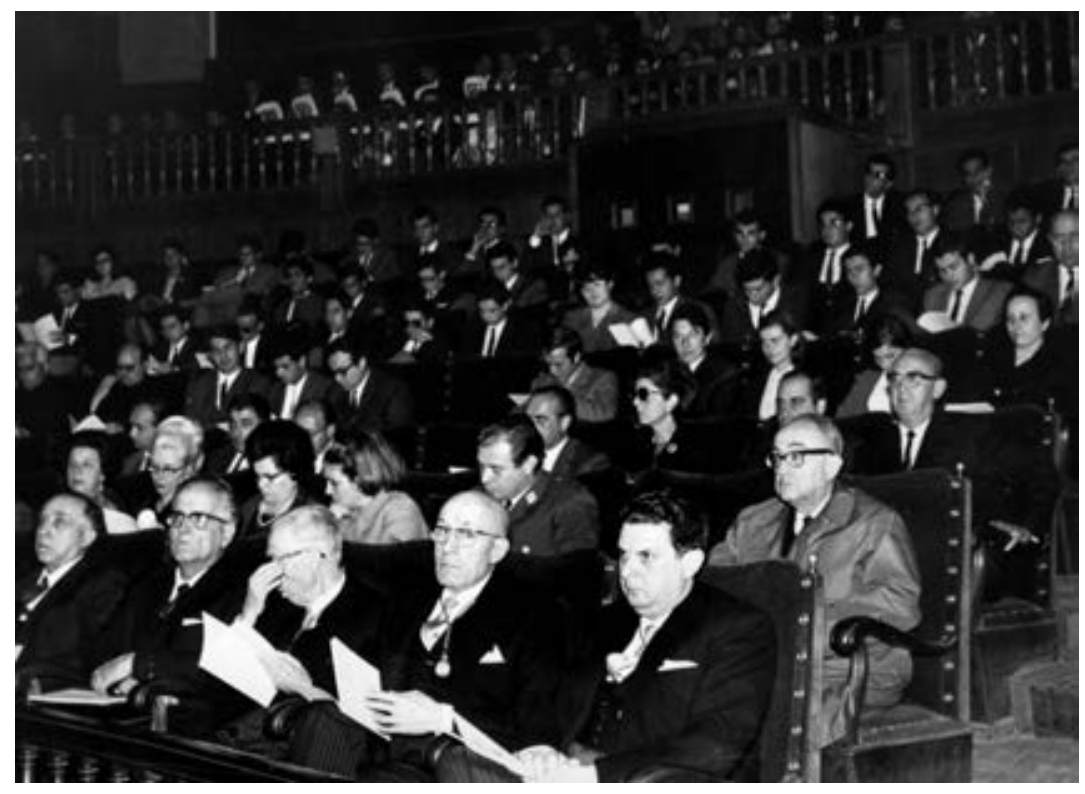




\section{AL PROFESOR RENÉ SARRAT}

JuAn Antonio Abascal Ruiz

Secretario General del Ilustre Colegio Oficial de Médicos de Zaragoza

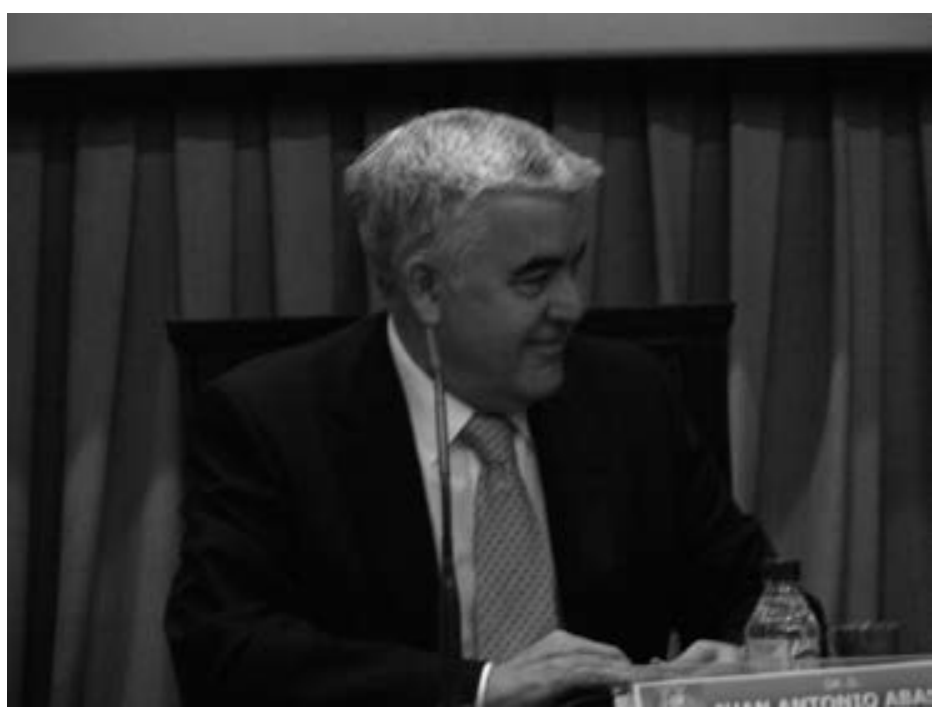

Juan Antonio Abascal

Hola René:

¿Sabes? Esta noche, como muchas otras, he tenido un sueño. La diferencia es que hoy puedo compartirlo contigo.

Sé que lo entenderás porque en los sueños no pasa el tiempo y, si lo hace, podemos recuperarlo entero.

Estoy en casa: Termino de llegar del colegio, no sé si hace frío o calor pero mi madre está viendo la calle tras los cristales de la ventana del salón. Digo buenos días y ella responde: «iCarmen, caliente la comida. Ya son las dos!». Me da un beso y me acerco a la ventana, buscando no sé qué reloj.

Sí, mi madre no se equivoca: Son las dos en punto de la tarde. En la puerta de clínicas de la Facultad de Medicina, don José Escolar está dando la mano a Víctor, Vicente, Santiago, José Maria, Sarrat y a alguno más.

Las dos en punto. ¡Faltaría más! Ese era el reloj de mi madre, para saber el tiempo que tenía para calentar la comida antes que mi padre, mi hermana Teresita (la más guapa del curso, LA BELLA) y mi hermano José Manuel (LA BESTIA) cruzaran el Paseo de Calvo Sotelo y subieran a casa. 
Han pasado años, o quizás no haya pasado ninguno porque sigo poniendo mi reloj con el mediodía de don José Escolar García.

Sigue el sueño con su falta de medida de tiempo y tú, René, me cuentas el porqué de esos motes y cómo sabías quién era yo. Yo sí que no sabía por qué me mareabais a preguntas Santiago y tú y menos aún que insistieses diciéndole, al para mí entonces profesor Rodríguez: «Pregúntale más. Seguro que no tiene ni idea y que acierta por chamba».

¿Sabes? Te odiaba.

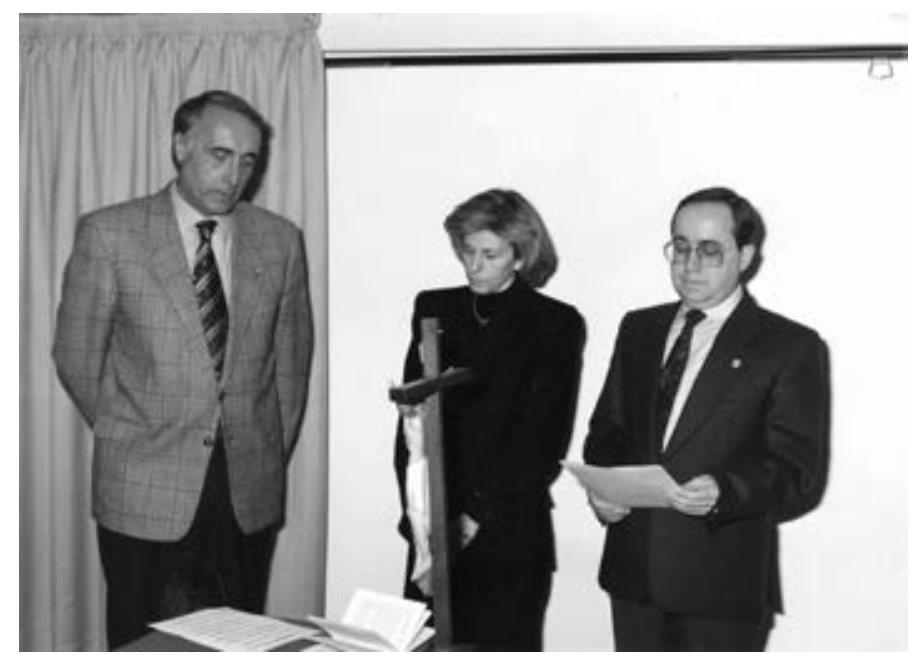

Junto a la Dra. María Castellano. Toma de posesión de la comisión Deontológica del ICOMZ

Santiago insistía con el tronco de encéfalo. ¿O era José María?

¡Treinta y dos preguntas contestadas para saber que, al final, don José me iba a picar la T, como siempre, y me iba a decir: « $i$ Vaya Vd. con Dios!».

Así parcial a parcial hasta que un día miré a Rodríguez, y le dije: «Profesor: no veo lo que Vd. me señala. ¿Puedo volver el cadáver?».

«-Hágalo.».

Lo hice: levanté la parrilla a pulso y, mirándole fijamente a los ojos, dije: «El esternocleidomastoideo».

Se oyó tu voz: «iHuy, Santiago, déjalo que está muy enfadado!».

Salí de la sala y me esperabas. Me dijiste: «Disculpa la broma. Ya sabes que tus hermanos fueron nuestros primeros alumnos y que los apreciamos mucho». 
No contesté; no digo lo que pensé entonces porque... Hubo ocasión para recordarlo y reír junto con Santiago Rodríguez, estando él de Catedrático y yo de Adjunto de Microbiología en el Colegio Universitario de Soria.

Continúo en la ventana de casa. Hay huecos, muchos, más de los que quisiera. Cierro los ojos y los huecos se llenan, termina la nostalgia y vuelve a sonar el reloj de Anatomía. Las dos.

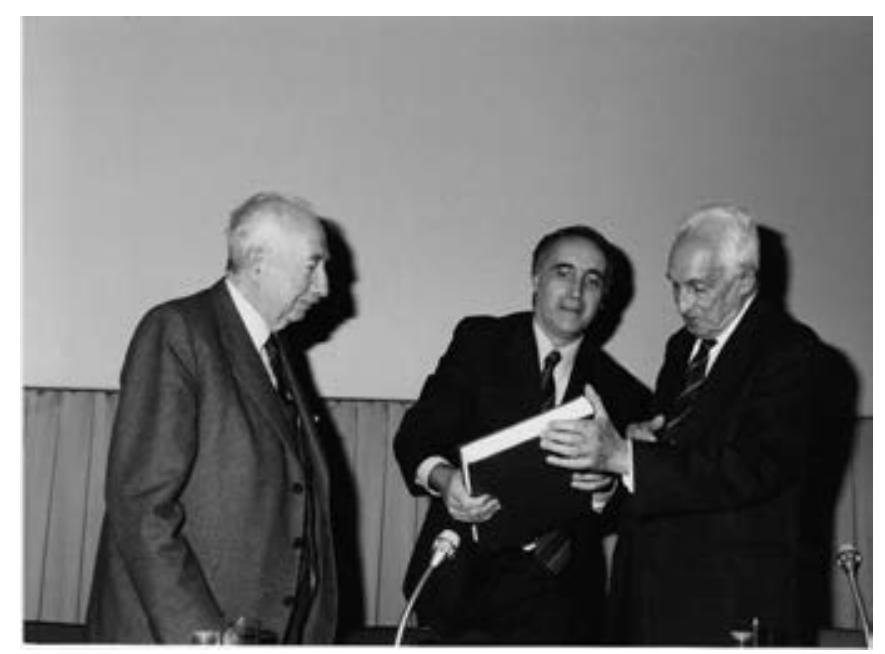

René junto a los Drs. Grande Covián y Severo Ochoa

Sé que mi madre prepara los últimos retoques a la mesa antes de que llegue mi padre. Sé que siempre será así y que no faltan pocos días para que pueda besar a mi madre y decirle buenos días, reñir con mi hermano porque se queda con mis «perras» y me despierta a las tres de la mañana para que vaya a clase. ¡Yo me lo sigo creyendo y deseo que siempre lo haga!

Hay noches en las que se duerme tras la trastada y Jesús, el portero, me lleva de la mano y llama a la puerta de casa. Mi padre se levanta y le despierta. Le echa la bronca, pero sé que, en el fondo, le hace gracia. Le oigo reír con mi madre mientras José sigue con su dulce sueño y yo velo hasta las ocho de la mañana mirando la cartera y restregándome los ojos para no dormir y llegar pronto a clase.

Sé que esta noche tú, María Teresa Abad, mi mujer, la tuya, el profesor Gandarias, José María Sebastián sentado en mi halda, en tu coche, tras cenar en Goyescos estuvimos echando mil risas. 
Tras magníficas explicaciones sobre el metabolismo, oídas en la charla en el Colegio de Médicos, llegó el momento de alabar las excelencias de una colación suave a esas horas de la tarde.

Todos de acuerdo con la norma preconizada, pero ¡ay, la carne no sé si es débil pero sí que debía estar muy buena a la par que abundante!

Tan solo José Mari y yo nos ceñimos a la norma.

Comentaste que, de vez en cuando, lo único que hacía soportable una dieta era la posibilidad de saltarla.

Pili, mucho más práctica, dirigiéndose a Gandarias, le preguntó: «Profesor: ¿Cómo sabe el estómago si es de día o de noche?». El académico respondió: «Buena pregunta». Levantando la mano pidió, no recuerdo si a Luis Lucientes o a Francisco Parra, un poco más de chocolate.

¿Sabes? Entra Paco Martín, el nefrólogo, nuestro común amigo, el hombre de la eterna sonrisa y peor cantador de jotas del mundo y compañero de mil y una guardias con tu hermana Nélida.

Me pregunta qué hago. No le digo nada. Le enseño este escrito. Ve a quién va dirigido y me pregunta por ti. No pasa de la segunda línea. Se ha quedado en cómo estás tú.

Bajamos a diálisis. Hoy le hace una fístula al hermano de leche de LA BELLA, aunque sé que ya no la recuerdas.

Termina la mañana. Paso bajo la ventana de donde estaba el salón de casa de mis padres. Miro. Mi madre está esperando. Giro la cabeza hacia el otro lado del paseo, hoy de Gran Vía, y deben ser las dos en punto porque don José os está dando la mano a todos.

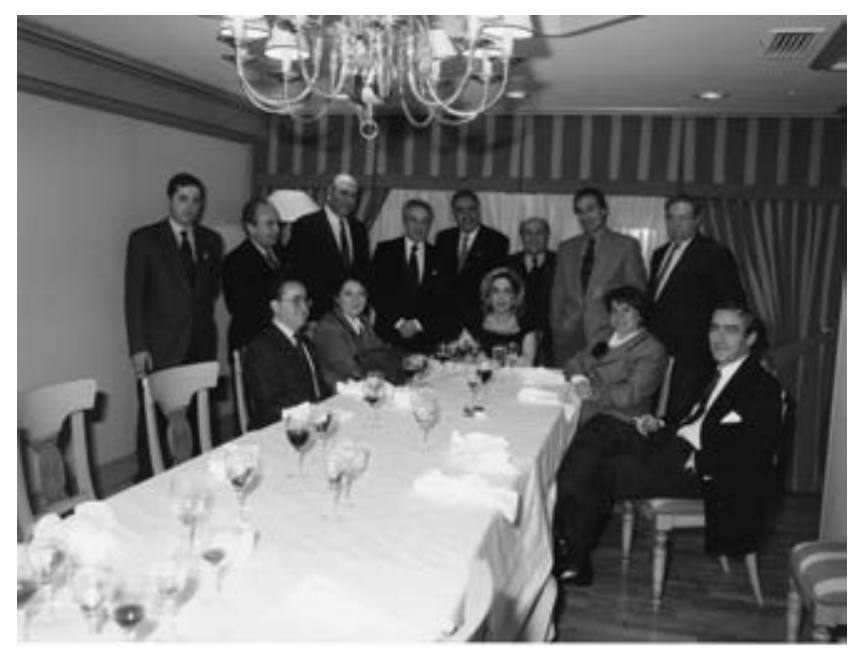

Celebración fiesta Colegio de Médicos 


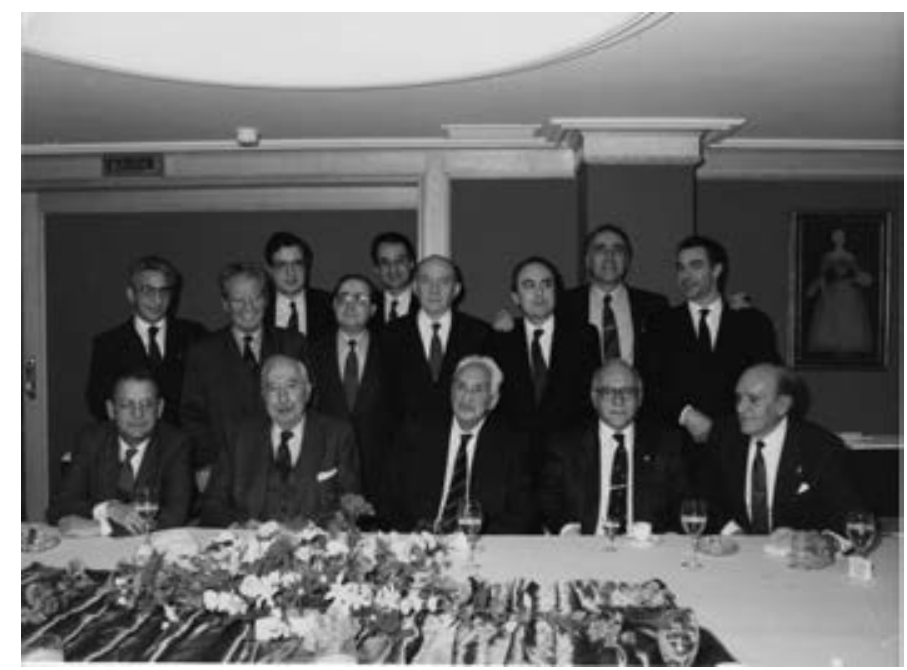

Primera fila: M. Bueno, F. Grande-Covián, Severo Ochoa, V. Camarena, F. Marín Górriz. Segunda fila: entre otros, S. Lorén, René Sarrat

Llego a casa, leo lo que he escrito y me acerco a dar un beso a mi suegra.

¿Sabes? Tampoco sabe quién soy pero, cuando le pregunto, no le importa nada. quiero».

Me dice: «No sé quién es Vd., pero sé que me quiere mucho y que yo también le

Veo que mi cara se pierde en la bruma que vuela en sus preciosos ojos azules.

Sé que esto que te he escrito, como mil cosas más que podría decirte, tras tantos años de colegio, facultad, conferencias, amigos comunes[...], no nos va a servir de nada ni a ti ni a mí.

¿Sabes? Voy a levantarme; Voy a llamar a Ana y no le preguntaré por ti, ni cómo te encuentras. Solo le diré que te quiero ver y darte un abrazo.

Quiero que me mires y, cuando te pregunten si recuerdas quién soy, solo digas que no, que no lo sabes pero que sí sientes que te quiero mucho.

Espero que Dios me dé oportunidad para que, como a ti, la gente que ya no conozca me abrace y le pueda decir: «No sé quién es $\mathrm{Vd}$. pero sé que me quiere».

Luego volveré la cabeza y quizás, solo quizás, haya un día en el que, al igual que hace mi madre en la ventana, veamos cómo la gente se da la mano.

Seguro que tú y yo, desde ese mirador sabremos quiénes son. Entonces, sí te podré enseñar esta carta y tú la leerás, dirás mi nombre y me dirás qué te parece... ¡A Aunque solo sea para criticarme!

Un beso para ti, querido profesor y aún más querido amigo. 


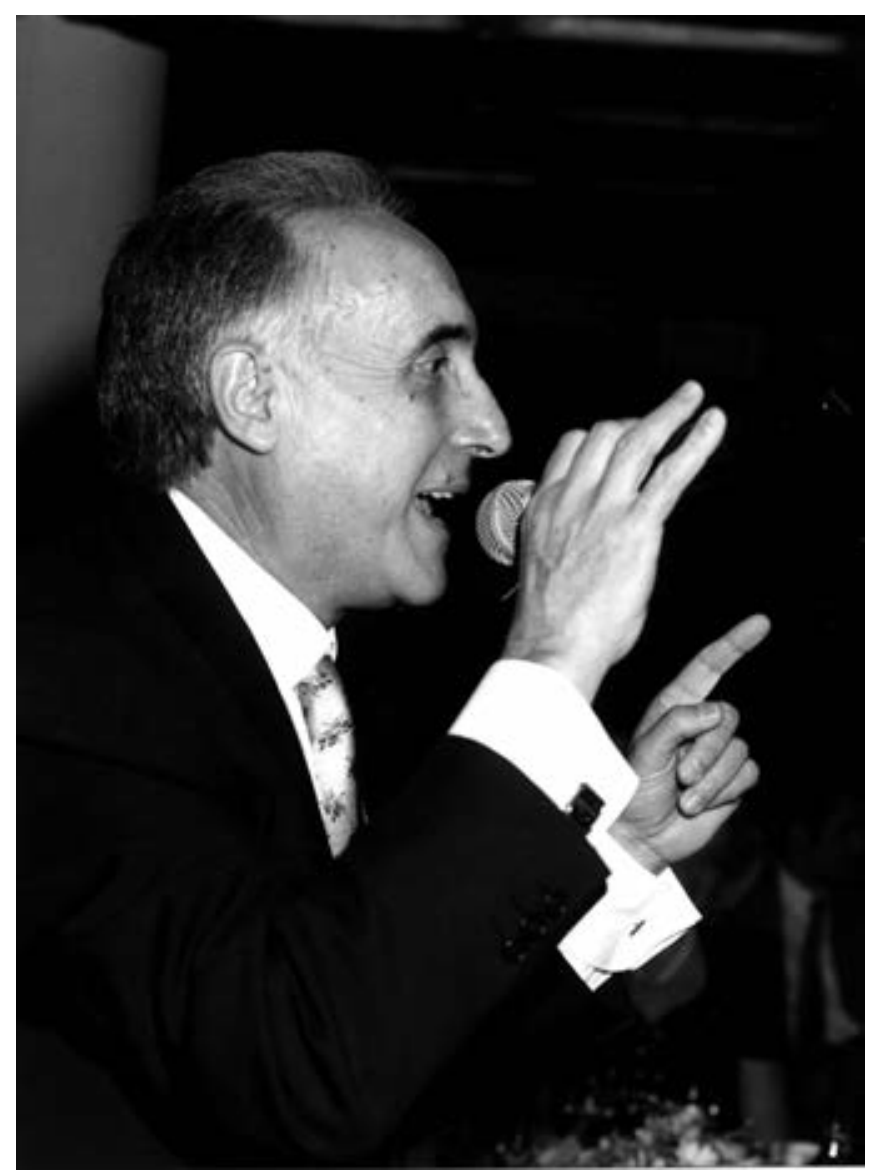




\title{
AL PROFESOR RENÉ SARRAT
}

\author{
JULIA BLASCO OQUENDO
}

Profesora Titular de Anatomía y Embriología Humanas

Facultad de Medicina. Universidad de Zaragoza

\section{Querido «jefe»:}

También podría haber usado el formal profesor Sarrat, pero siempre te ha gustado que te llamáramos así, y a mi decírtelo, quizás por tu forma de serlo sin ejercer como tal, siempre dejando libertad para todos y todo dándonos opción de demostrar nuestra responsabilidad, desde que éramos unos PNN, ahora no tendría mucha gracia.

Recuerdo con mucha claridad la primera vez que te vi. Era durante el Congreso de Barcelona y Santiago Pellejero nos presentó, ya que según él había muchas posibilidades de que vinieras a Zaragoza a ocupar la plaza de don Luis Jiménez, pero antes nos había avisado que de ser así estaríamos muy bien ya que eras una excelente persona, ¡cuántas veces me he acordado de esas palabras!

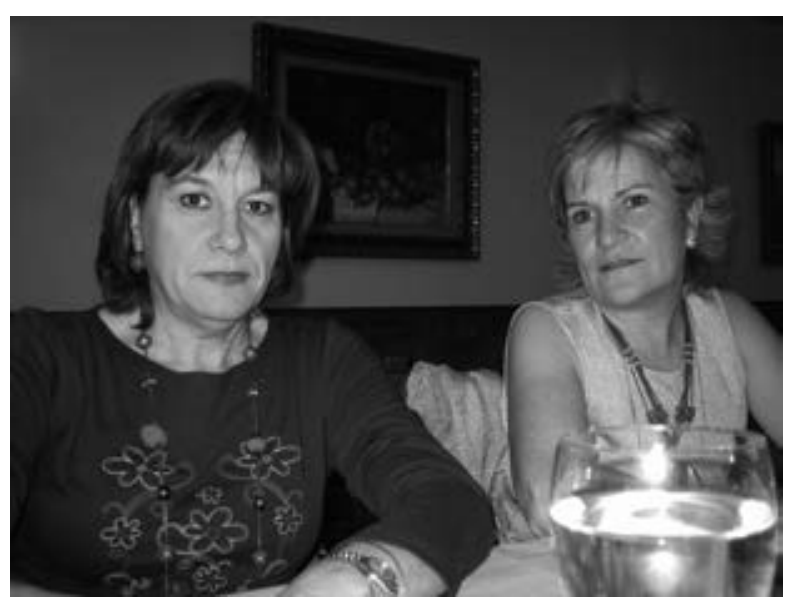

Julia Blasco y M. ${ }^{a}$ Asunción Escolar. Homenaje a M. ${ }^{a}$ Jesús Pinilla 
Trabajar contigo todo este tiempo ha sido una delicia, siempre con tus palabras amables al punto de la mañana, siempre preocupándote tanto de la clase que teníamos ese día como de nuestros problemas personales, e incluso fijándote en si habíamos ido a la peluquería.

Profesionalmente ha sido un honor verte trabajar, como docente has sido un MAESTRO, ir a clase contigo y oírte explicar Anatomía era disfrutar de la asignatura, de tu forma de hacer sencillo lo que es muy complicado, aprender cómo se deben plantear los temas y, en cuanto a la cara de los alumnos, qué decir de su atención y de su tranquilidad al ver que todo era tan sencillo. Y qué decir de tu labor investigadora, a mí me has enseñado desde el principio todo, contigo y gracias a ti hice mi tesis doctoral y, a partir de ahí, el resto del currículum.

Tenerte como miembro de un tribunal era saber que aún en los momentos de más nervios con tu mirada y tus gestos de asentimiento, dabas la fuerza suficiente para seguir hacia delante y ser capaz de terminar la exposición.

¡Cómo te vamos a echar de menos! Casi aún no te has ido y ya se nota que falta tu mano en todas las cosas del día a día, ya sé que nos vamos a ver muy a menudo, que siempre estarás con nosotros, pero no va a ser igual, tu moderación, tu tranquilidad, tu dejar vivir, tu cariño y tu ánimo a todas horas, eso tendremos que aprender.

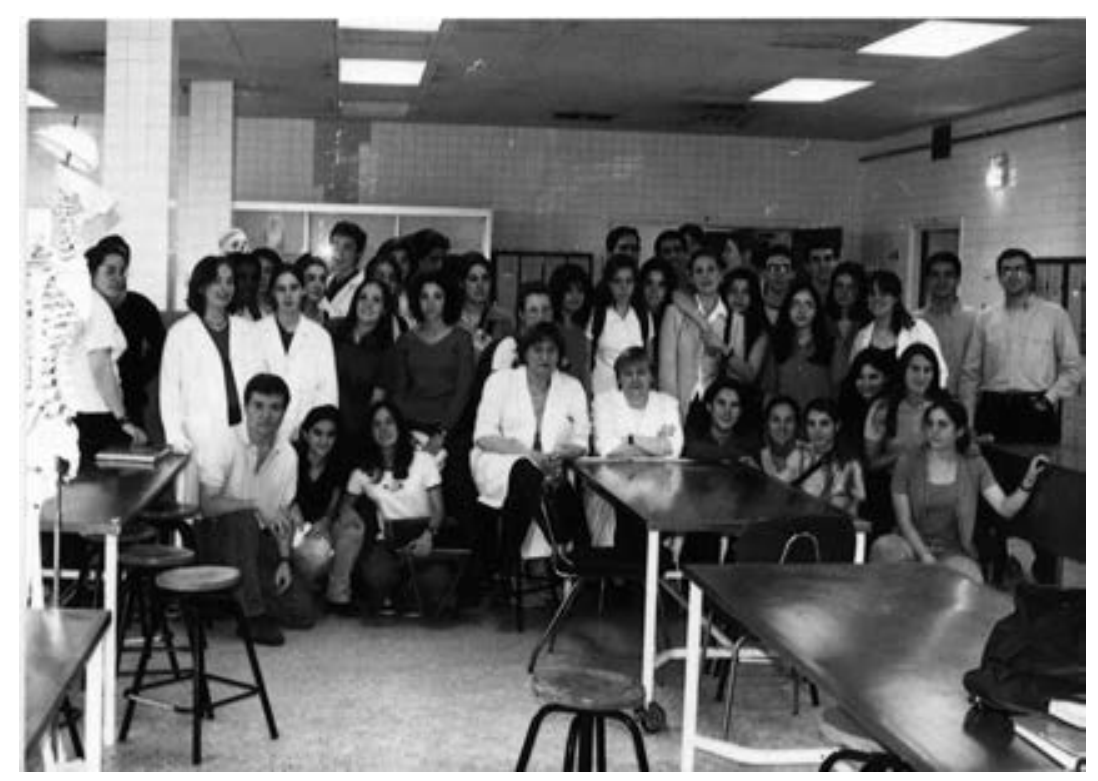

Promoción de Medicina 1999 - 2005 


\section{AL PROFESOR SARRAT}

Carmen Martínez

Profesora Titular de Anatomía y Embriología

Facultad de Medicina de Zaragoza

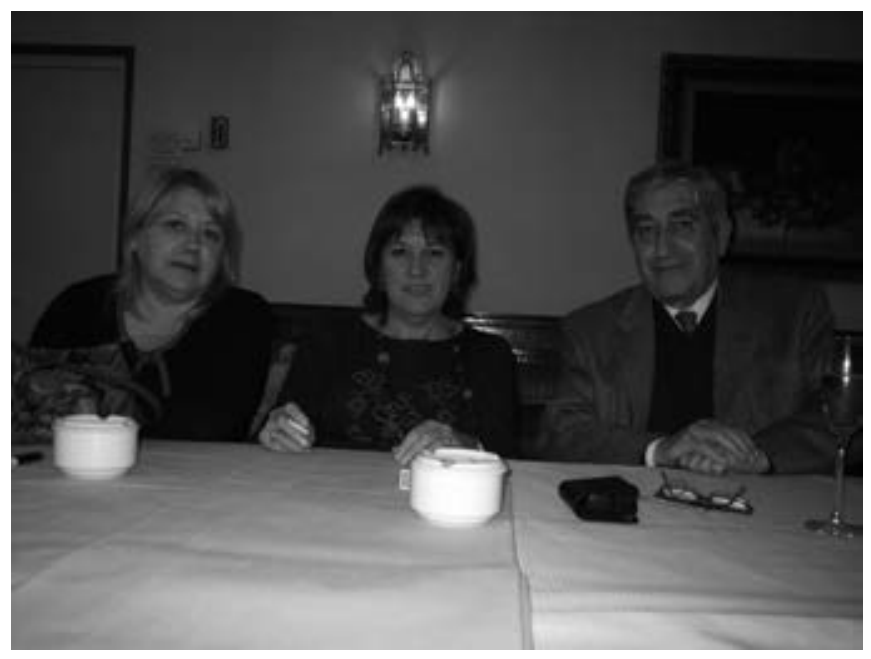

Carmen Martínez, Julia Blasco, José Luis Nieto.

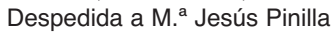

Desde que comencé mi andadura en la vida universitaria, querido profesor, has estado presente en mis momentos académicos más importantes; miembro del tribunal de mi tesis doctoral. Miembro del tribunal de mi oposición a Profesor Titular de Universidad (antes Profesor Adjunto).

Una vez obtenida la plaza de Profesor Adjunto, las circunstancias hicieron que ocuparas la Cátedra de Anatomía Humana B de la Facultad de Medicina de Zaragoza, donde se me asignó la plaza de Profesor Adjunto que estaba vacante.

Así desde 1983, nuestra vida profesional ha viajado estrechamente unida, pero no solamente la actividad diaria dentro de la Facultad, sino también el respeto, el cariño y la confianza que, desde el primer momento, nos brindaste, ha hecho que el ir día a día a trabajar fuese como estar entre miembros de una gran familia, que como en toda gran familia, aunque en algunos temas puntuales no todos los miembros opinaran del mismo modo, tú sabías dulcificar la situación para llegar a un completo entendimiento. 
Llegado el momento de la jubilación, algunos nos sentimos entristecidos por no tener al profesor Sarrat al otro lado del pasillo. Cuando llegamos por la mañana saber que, aunque entremos en su despacho, no lo vamos a encontrar hace que se nos encoja el corazón. Que a media mañana en unos minutos de «recreo» no esté para contarnos sus experiencias y chascarrillos es algo que tardaremos en superar.

Profesor Sarrat, aunque no podamos tenerte día a día entre nosotros, siempre estarás presente, en nuestros corazones y en nuestra mente e intentaremos seguir tus enseñanzas académicas pero sobre todo tus enseñanzas vitales. Tu amabilidad, afabilidad y cariño nos acompañarán siempre.

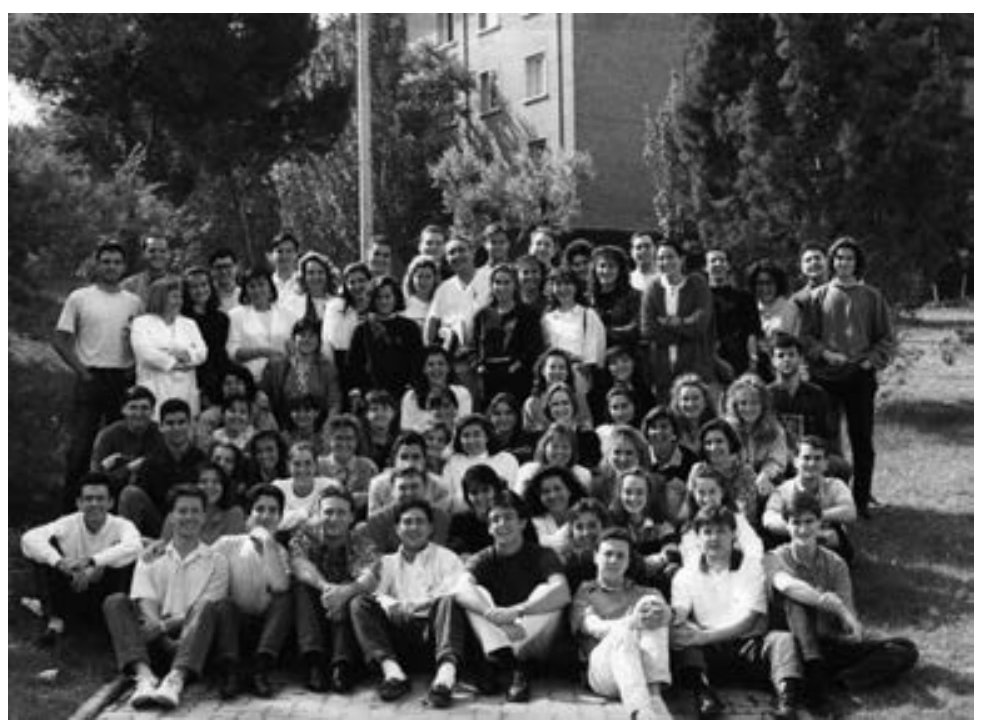

Promoción de Medicina 1988 - 1994 


\section{AL PROFESOR RENÉ SARRAT}

M. a ASUNCIÓN ESCOLAR

JUAN DE DIOS ESCOLAR

Profesores Titulares de Anatomía. Departamento de Anatomía e Histología Humanas

Facultad de Medicina de Zaragoza

Dicen que al amanecer es cuando mejor se aprecia el horizonte. Puede que sea por eso de la luz. Yo creo que si al comenzar el día te detienes a mirar la línea que une la tierra con el cielo es porque quieres verlo de verdad. Cuando comenzaste a estudiar Medicina tu horizonte estaba en la traumatología. Pero por culpa del corazón, concretamente de las coronarias, comenzó para ti un nuevo día en el que te paraste a mirar el horizonte, y viste el punto donde podrías tocar el cielo.

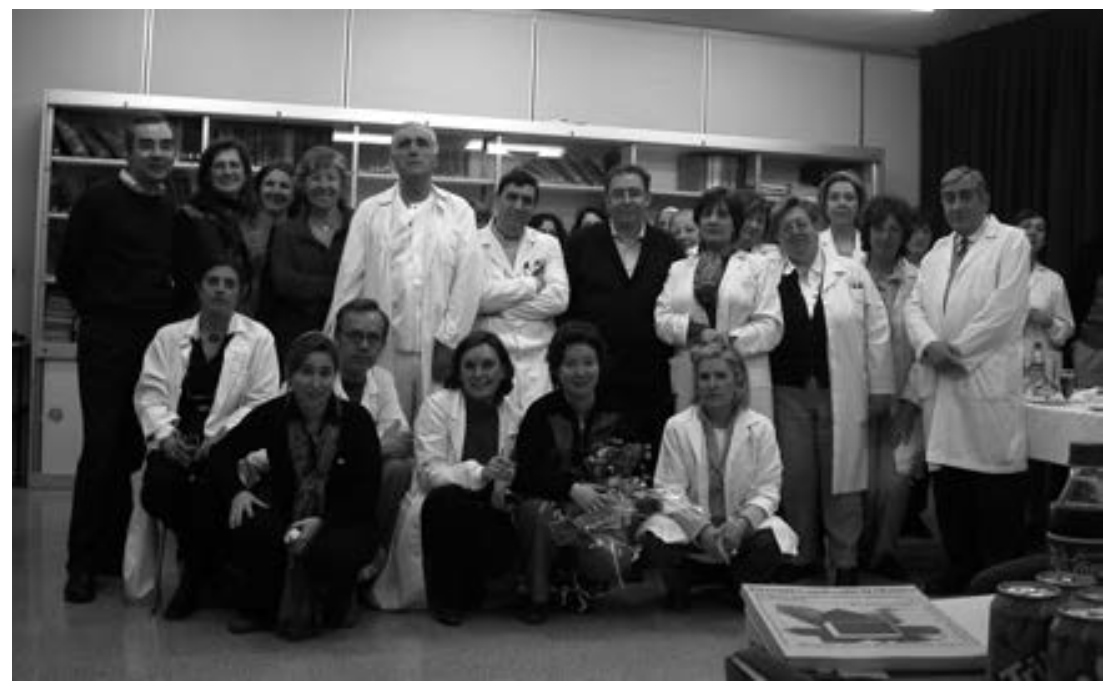

Primera fila: M. J. Barral, A. Cisneros, J. D. Escolar, N. Pes, Ana Cris, M. ${ }^{a}$ A. Escolar. Segunda fila: Entre otros, P. Contamina, P. Parra, R. Sarrat, M. Lahoz, J. Whyte, E. Sinués. M. T. Peg, A. Torres, M. J. Azanza y J. L. Nieto 


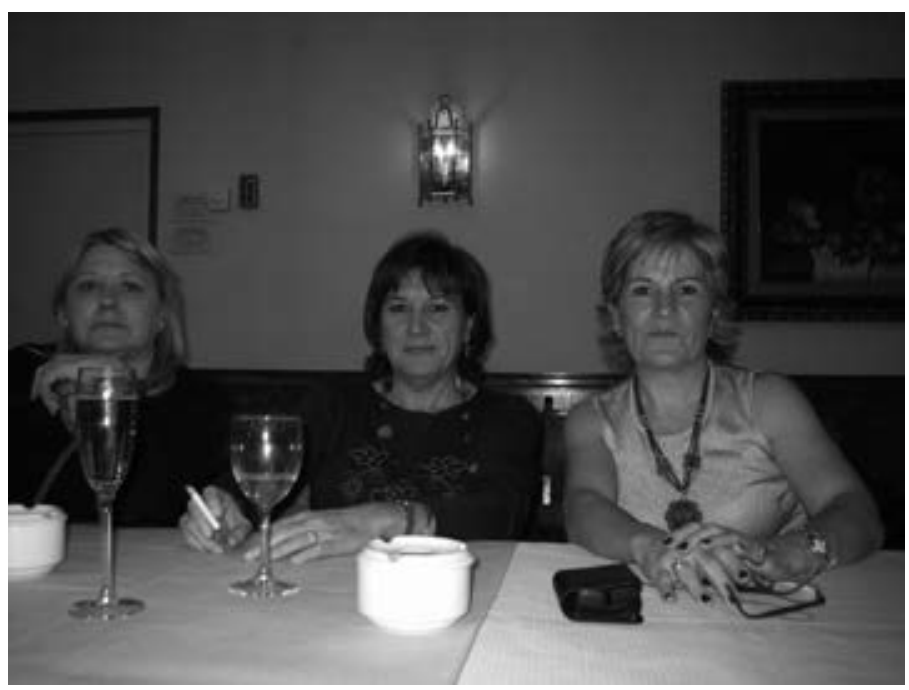

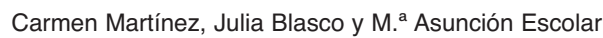

El comienzo del camino para llegar a él, era tan ancho como largo. Precisamente no se encontraba en una llanura y su final estaba en una cima. El punto donde la tierra tocaba el cielo pasaba por la universidad y concretamente por la anatomía.

Emprendiste ese camino con entusiasmo. Con esas ganas de comer que se tienen cuando se tiene hambre de verdad. Siempre se te ha visto con hambre de aprender y de enseñar.

Cuando te conocimos eras para nosotros Sarrat. ¿Por qué Sarrat y no René? Porque el que nos presentó daba siempre el usted. Tú eras un estudiante de medicina con mucho aplomo. Nos dijeron que tenías ese acento porque eras catalán. Nosotros éramos unos niños con una lengua de trapo andaluza difícil de hacerse entender y que tenían todavía que crecer. Mientras crecíamos, oíamos hablar de ti y crecía una necesidad de conocerte un poco más: cómo dabas las clases, lo amable que eras en los exámenes. Se decía que "vendías la anatomía», que eras un comercial del conocimiento. Los convencías. ¿Dónde iban estar mejor los estudiantes que en clase? Exponías un tema bonito, interesante para el médico, que daban ganas de aprenderlo; todos en tensión como en una película de suspense con final feliz.

También se oían comentarios más mundanos que te relacionaban con alguna señorita, lo que le daba a tu persona todavía más humanidad.

Nosotros íbamos creciendo en altura y sabiduría, pero nunca te alcanzamos. Comenzamos a llamarte René y te fuiste a Bilbao. Todos nos alegramos de tu promoción profesional. También nos felicitamos de tu matrimonio con Ana. Tus hijos: Rebeca 
con la que tuvimos la suerte de trabajar durante dos años; te felicito por ese pedazo de hija. Marco Antonio que lo conocemos menos y del que solo se puede hablar bien. Luego te hiciste isleño y, por fin, volvisteis a Zaragoza.

Qué suerte, por fin íbamos a trabajar contigo. ¡Cuánto aprendimos! Rápidamente te ganaste el respeto de los que no te conocían y los que te conocimos no fuimos defraudados. Lo mejor, tu disponibilidad y la claridad de cómo planteabas todo; realmente no había problemas. Contigo era todo tan sencillo que, a veces, confundíamos el trabajo con la monotonía. En una ocasión, quise emociones fuertes y te comenté la posibilidad de introducir unas supuestas mejoras docentes. Cuando nos reunimos para programar la asignatura te pareció correcta mi propuesta; íbamos a modificar el método de examen. Diste el visto bueno y nos pusimos a trabajar en la idea. Luego cuando la idea se transformo en realidad y la realidad no era lo que yo había previsto, supiste hacerme ver dónde me equivocaba. Tras el fracaso, volvimos al punto inicial. No hubo ninguna palabra más alta que otra ni un solo reproche. Se intentó, no salió y había que tirar para delante, sin que el alumno saliera perjudicado, como siempre. Yo tuve la gran oportunidad de estar junto a alguien que sabía su oficio y lo sabía enseñar. Aprendí una gran lección, creo que la segunda más importante de mi vida.

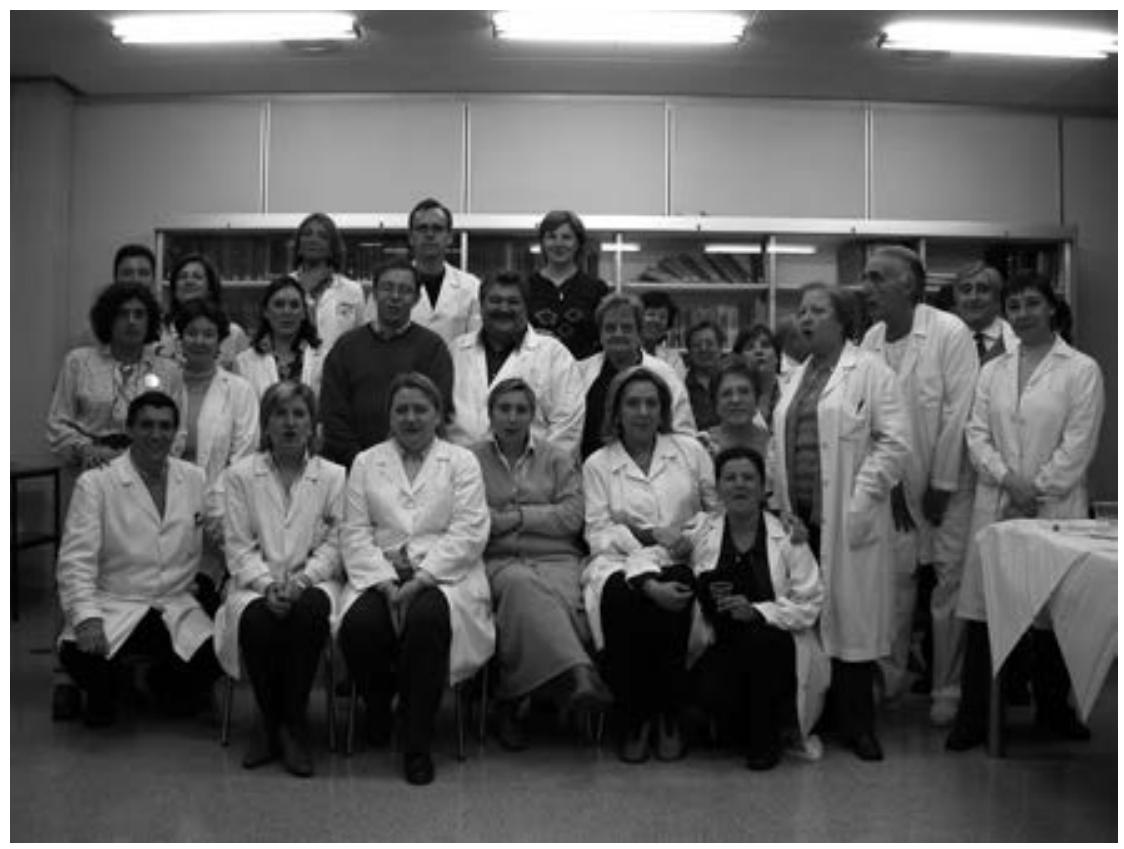

Despedida al anatómico mejicano Juan Guzmán 
Cuando, después de subir tres pisos, hemos llamado a tu puerta, siempre nos la has abierto. Cuando nos encontramos ante el cadáver, pálido, frío, le movemos la cabeza a la derecha, tocamos el borde del esternocleidomastoideo, no nos sentimos solos, porque nos has enseñado el objetivo de ese gesto.

Ahora no sé a dónde miramos, a tu horizonte o al nuestro. Pero sí sé lo que queremos ver. Queremos verte cerca de donde la tierra toca el cielo, cerca de donde te propusiste llegar.

Los profesores decimos todos los meses de junio a mucha gente adiós. En ocasiones, ese adiós es un hasta luego: nos veremos el próximo curso. En otras, al decir adiós, notamos cómo se contraen los pilares del istmo de las fauces, los estiloihoideos. Tú sabes muy bien qué se siente cuando se estrecha la faringe, al decir adiós. Eso ocurre por darle a tus alumnos lo mejor de ti, porque gracias a ti la próxima vez que los veas ya no son los mismos, son más adultos, más profesionales. Cada alumno que ha trabajado contigo lleva algo de ti.

Hemos dicho muchas veces adiós y cada vez nos cuesta más. Ahora nos decimos adiós y sentimos cómo se contraen los pilares del istmo de las fauces, como seguramente te pasará a ti. Vamos a intentar que sea un hasta luego, porque queremos tener un amigo cerca. Queremos sentir tu apoyo y sobretodo queremos cerca a alguien que nos siga enseñando. 


\title{
PROFESOR RENÉ SARRAT
}

\author{
Pedro Cía Gómez
}

Catedrático de Patología y Clínica Médicas

Jefe de Servicio de Medicina Interna del HCU Lozano Blesa

Conocí al profesor Sarrat cuando inicié los cursos de Anatomía. Era él también estudiante, pero ya de cursos superiores y alumno interno pensionado. Colaborador muy apreciado ya por el profesor Escolar, notábamos todos la confianza que ya el maestro depositaba en este joven discípulo.

En aquella época, años 1959-60, la Cátedra de Anatomía que dirigía el profesor Escolar, recién incorporado entonces al Claustro de la Universidad de Zaragoza, era no solo un espacio de aprendizaje, sino también un lugar de convivencia de profesores y alumnos. Las sesiones en la sala de disección eran cada día un verdadero seminario con el que se encontraba ocasión de preguntar, resolver dudas... hacer, en definitiva, ese aprendizaje ya activo y personalizado hacia el que se orientan cada vez más los modernos planes de estudios. Pero también y con frecuencia se podría hablar con los profesores y entre nosotros de cualquier tema que entonces nos pudiera interesar... En fin, se cumplía de manera natural esa idea de Alfonso el Sabio de que la Universidad es «ayuntamiento de maestros y discípulos para aprender los saberes».

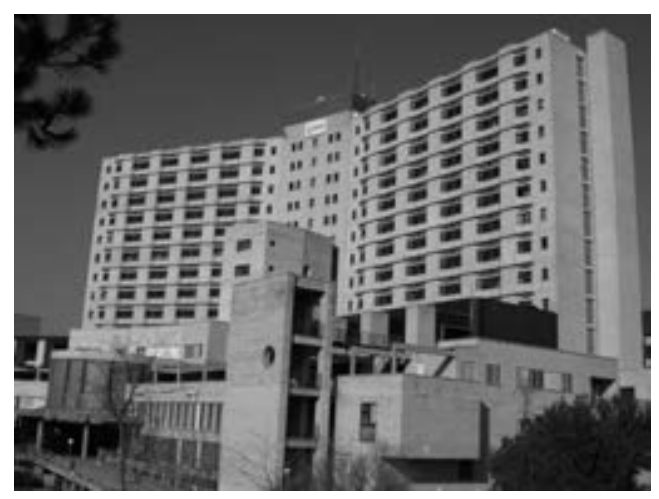

Hospital Clínico Universitario Lozano Blesa 
No es de extrañar por eso que acabásemos conociéndonos todos bastante en ese clima de grata convivencia. Por eso podíamos aprender también de la forma de ser y de actuar de nuestros profesores y de los que, como René Sarrat, se preparaban para la carrera docente.

Tuve más adelante el privilegio de trabajar bajo la dirección del profesor Escolar y tuve entonces la ocasión de tratar de forma más personal y continuada a René Sarrat, ya profesor de Anatomía y aspirante a catedrático.

En esa época, años 1965 a 1967, el grupo de investigación dirigido por su maestro derrochaba imaginación y voluntad para llevar adelante estudios de importancia y de repercusión nacional e internacional con medios frecuentemente limitados. En ese clima de indudable trabajo y entusiasmo de todo el grupo, destacaba el joven profesor Sarrat que ya se perfilaba como un gran investigador. Tanto en los trabajos que dirigía, como a la hora de dar consejos para el quehacer científico destacaba su rigurosa metodología basada siempre en la racionalidad, aun a riesgo de tener que renunciar a una hipótesis previa o tener que repetir un experimento o retrasar la obtención de unos resultados.

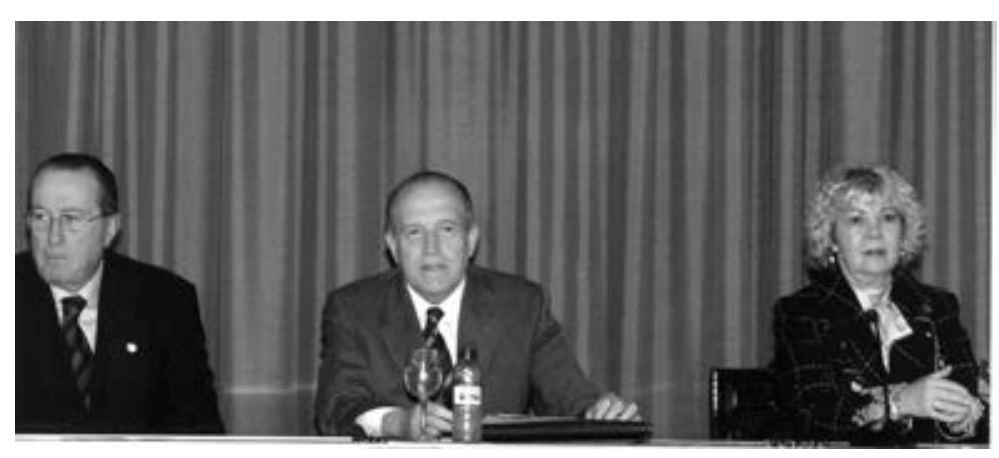

El Profesor Pedro Cía presidiendo un acto en la Facultad de Medicina junto a la profesora Milagros Bernal

El perfil científico de René Sarrat puede resumirse diciendo que sus dos caras son la honradez y la inteligencia, cualidades que, a su vez, le hacían ser exigente con su propio trabajo y con el de los demás.

Sin embargo, la convivencia diaria con René Sarrat permitía descubrir una atractiva personalidad.

Destaca en él la generosidad. Si se involucraba en un trabajo, era él quien asumía las dificultades que pudieran presentarse a cualquiera de los compañeros del equipo. 
Es persona, por otra parte, que irradia optimismo. Era así en su grupo de trabajo; pero también entre sus alumnos. Me contaba que, cuando los recibía a principio de curso en la presentación de la asignatura, les animaba a que cursando su disciplina «intentaremos pasarlo bien»... Debía ser así por lo que luego conocíamos del testimonio de los alumnos.

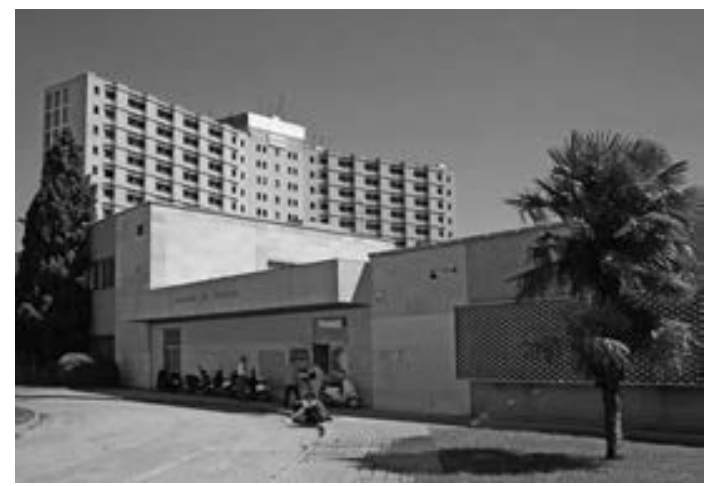

Facultad de Medicina de Zaragoza

Quizá el motivo de que esos alumnos suyos lo pasaran bien al cursar una disciplina como la Anatomía, que en principio se presentaba difícil radicaba no solo en un trato habitualmente cercano y en su proverbial claridad de exposición, sino también en su permanente inquietud por transmitir conocimientos que pudieran después ser interés para el ejercicio práctico de la Medicina.

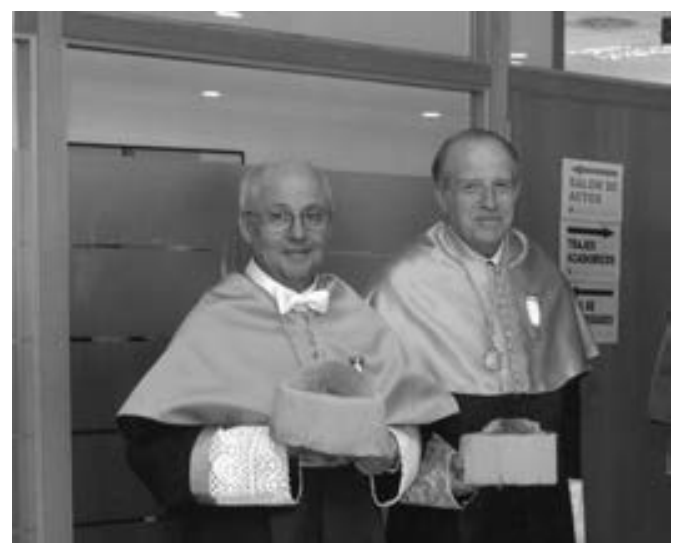

Profesores. A. Vera y P. Cía 
Esa inquietud le llevaba continuamente a mantener diálogo e intercambio de ideas con los compañeros que nos dedicamos a las disciplinas clínicas y al trabajo en el hospital.

En la Facultad de Medicina y desde su cátedra asumió diversos cargos para los que fue elegido y, entre ellos, cuando estuvo destinado en Bilbao, el de Decano en cuya Facultad dejó excelente recuerdo.

Su proyección fue, sin embargo, más allá del ámbito de la Facultad y se interesó también por otros temas de la Medicina y de la cultura en general, que quedaron reflejados en escritos y conferencias.

En fin, creo que por imperativos de la edad y de las leyes perdemos en el Claustro uno de esos miembros de referencia que, por su formación científica y su personalidad, no solo son buenos profesores de sus alumnos, sino maestros para todos. 


\title{
HOMENAJE AL PROFESOR RENÉ SARRAT
}

\author{
CARMEN DE LA HOZ TORRES
}

Médico Especialista en Medicina Interna. Profesora Titular de Histología

Facultad de Medicina. Universidad del País Vasco

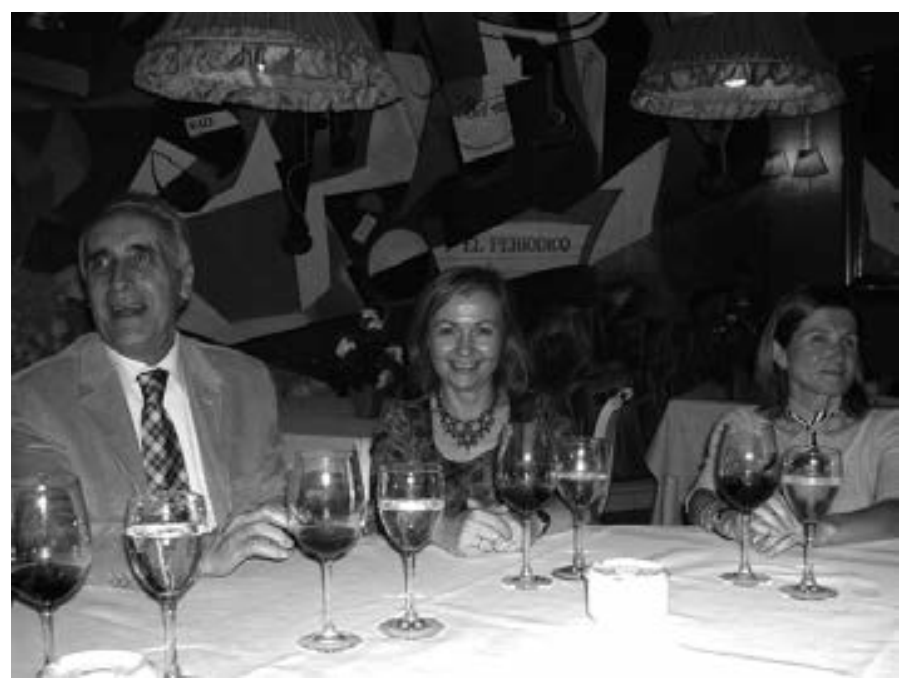

René junto a Carmen de la $\mathrm{Hoz}$

Me han pedido que resuma el significado para mí de una persona, el profesor René Sarrat Torreguitart. No es fácil trasladar a unas líneas la huella que algunas personas que hemos conocido a lo largo de la vida han dejado en nosotros. René ha sido para mí un profesor carismático, un maestro, precisamente un término que a él, que alguna vez se reconoció «maestro de escuela frustrado», creo que le gustará. René ha sido un docente vocacional y apasionado capaz de despertar en nosotros, unos imberbes alumnos de primero de Medicina, la pasión por la Anatomía y por la Medicina.

Su dominio de la Anatomía y su dedicación a la docencia se ven reflejadas en el hecho de habernos explicado el programa completo de la asignatura a lo largo de dos cursos académicos, día tras día. Varios de sus alumnos, inspirados en él (y en algún otro profesor excepcional que tuvimos la suerte de tener), nos hemos dedicado a la universidad y sabemos el trabajo y la dedicación que entraña la preparación de clases al nivel que él las impartía y, en su caso, prácticamente en solitario. 
Viene a mi memoria aquel anfiteatro repleto de alumnos, en el año 1974, y el silencio sepulcral que se hacía en el aula cuando él, bata impecable, pizarra y puntero en mano, trepanaba al auditorio con la mirada antes de comenzar la clase, siempre con las mismas palabras: «Nos ocupamos hoy del estudio de... », para ir a continuación desgranando de un modo fluido y aparentemente sencillo (los maestros tienen esa habilidad, hacer sencillo incluso lo que es complicado) el contenido de la lección de cada día. Además de una preparación esmerada e impecable de cada tema, había algo de mágico y electrizante en aquel aula, una especie de aura que, a otros y a mí, nos hacía sorber con fruición conceptos que, de otro modo, hubieran resultado más áridos y aburridos.

Para René, la clase era algo sagrado. Que alguien tratara de interrumpirla por el motivo que fuera lo vivía como una especie de profanación y esto motivó que, en alguna ocasión, trepara por las escaleras del anfiteatro (alguien en la puerta situada arriba trataba de informar sobre un tema político, cosa no infrecuente en aquel tiempo), blandiendo el puntero de un modo que a mí me hizo pensar en el Cid Campeador arremetiendo contra los «infieles».

Una gran película, El Club de los Poetas Muertos, hace la semblanza de un profesor carismático, John Keating, de su capacidad para inspirar a sus alumnos, para ser faro que ilumina y orienta. René, tú has sido faro para muchas generaciones de estudiantes de Medicina. Gracias, Maestro. 


\title{
AL PROFESOR DOCTOR DON RENÉ SARRAT TORREGUITART EN LA FECHA DE SU JUBILEO (70 AÑOS DE SU NACIMIENTO)
}

\author{
José Manuel Gómez Beltrán
}

Profesor de Anatomía. Facultad de Medicina. Universidad de Zaragoza

Miembro Numerario de la Real Academia de Medicina de Zaragoza

Mis primeros recuerdos del doctor Sarrat se remontan a los primeros años de docencia como Ayudante de Clases Prácticas de Anatomía Humana en la Universidad de Zaragoza. Aunque yo pertenecía a la Cátedra B del profesor don Luis Jiménez González y el doctor Sarrat a la A (después, Departamento Anatómico), del profesor don José Escolar, ambas cátedras se alternaban cada año en la enseñanza a los sucesivos cursos de estudiantes. Como la programática era distinta en dichas cátedras, se procuraba que para los dos cursos de Anatomía (1 y 2), los alumnos se adscribieran a la misma cátedra, y así no variaran los conocimientos de la materia anatómica, por lo que la relación entre ambas fue siempre muy estrecha. Esta colaboración era todavía más notoria entre los colaboradores que trabajábamos en dichas cátedras, pues compartíamos la sala de disección común, en la que se realizaban las prácticas y técnicas anatómicas.

Desde muy temprano, mientras yo dirigía mis pasos a la Osteología, el doctor Sarrat se encaminó al cultivo de la Histología y la Neuroanatomia, que era el «caballo de batalla» de la línea investigadora del profesor Escolar, por lo que se separaron nuestras relaciones. Sin embargo, volvimos a coincidir en nuestra formación postgraduada como becarios en la Universidad de Kiel (Alemania), aunque en distintos departamentos, donde progresamos en los conocimientos y formación investigadora. Incluso en la residencia de profesores Haus Welt Club, donde tuvimos amigos comunes.

Al regreso a nuestro país, nuestros caminos se separarán claramente. El doctor Sarrat opositó y obtuvo la Cátedra de Anatomía del País Vasco, en Bilbao, y, posteriormente, tras el paso por el Colegio Universitario de las Palmas de Gran Canaria, regresó a Zaragoza. 
Así, en 1983, al jubilarse en la Cátedra B el profesor don Luis Jiménez, a la que yo pertenecía como Profesor Adjunto Numerario, fue nombrado Catedrático el profesor Sarrat. Desde esas fechas volvimos a tener una estrecha colaboración, que se ha mantenido hasta nuestros días, y de la que guardo gratos recuerdos. Desde los sentidos homenajes al profesor Escolar a su jubilación en Zaragoza y en Soria, hasta la común investigación en Neuroanatomía y Embriología. Mis propios hijos, Enrique y Virginia, estudiantes por entonces, fueron alumnos del profesor Sarrat; Virginia en Anatomía de 2. ${ }^{\circ}$, y a Enrique le dirigió sus trabajos de investigación embriológicos, cuando era alumno interno pensionado de la cátedra, y que culminaron en su tesina de licenciatura.

Uno de los más gratos recuerdos que guardo del profesor Sarrat es el de mi presentación a los que iban a ser sus alumnos, y a los que felicité por la suerte de poder aprender la Neuroanatomía con uno de los mejores expertos, que entonces había de esta prometedora especialidad. La Anatomía Comparada despertó también sus inquietudes de tal forma que se doctoró en Veterinaria.

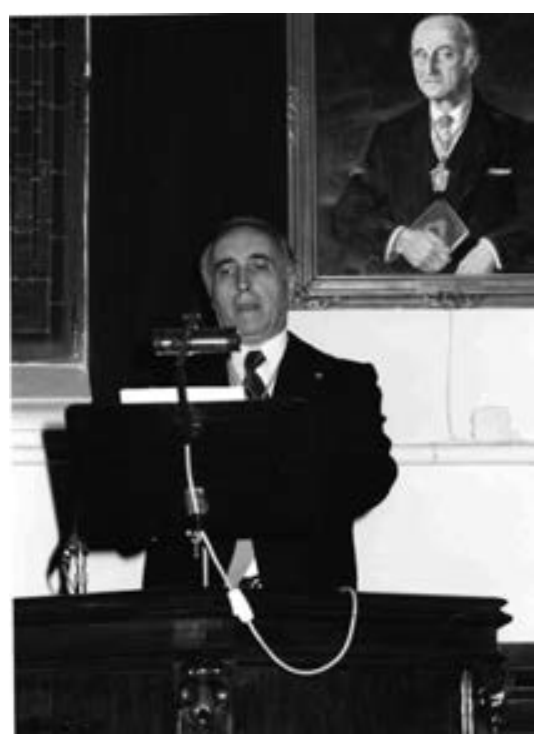

Ingreso del profesor Sarrat en la Real Academia de Medicina de Zaragoza

Posteriormente, la colaboración del trabajo diario en el departamento, con las dos cátedras, así como las de Histología, Genética y otras que se adscribieron al de Ciencias Morfológicas fue muy estrecha y cordial, y al ser elegido director de dicho departamento, no tuvo problemas de integración, con los profesores, alumnos y personal de servicios, lo que prueba su talante dialogante y ecuánime en sus decisiones. 
En su labor investigadora, formó a muchos colaboradores y dirigió publicaciones en numerosas revistas como en la Revista European Journal of Anatomy, de la que fue nombrado presidente del comité asesor.

Otro lugar de mi coincidencia con el profesor Sarrat ha sido el de la Real Academia de Zaragoza. Ambos fuimos elegidos, simultáneamente (1986, 1987), Académicos Numerarios, y colaboramos en esa Institución, en la Sección de Ciencias Fundamentales; y, así, tanto en la calificación de trabajos como en la concesión de premios o en la intervención en las sesiones científicas, teníamos un criterio común. La Memoria Académica del doctor Sarrat sobre La Diferenciación Sexual del Sistema Nervioso, fue una valiente aportación a la investigación en Neuroanatomía, y lo mismo sus trabajos sobre mediadores químicos en las neuronas.

También son de reseñar sus trabajos de Deontología Profesional. Fue presidente de la Comisión de Ética, y de la Academia de Ciencias Médicas del Colegio de Médicos de Zaragoza, y con él todos colaboramos y, especialmente, mi hijo el doctor Enrique Gómez Barrena, actualmente catedrático de la Universidad Autónoma de Madrid, que es deudor del profesor Sarrat, pues él fue uno de sus maestros en su formación docente e investigadora.

También mi hija Virginia, pediatra ejerciente, encaminó sus primeros pasos en Embriología en el Departamento del profesor Sarrat, donde se doctoró en 1994, con una tesis sobre Embriología

El impulso docente e investigador del profesor Sarrat se hizo notar, especialmente entre los profesores de la cátedra pues su continua dedicación servía de ejemplo para todos, aunque la mayoría de nosotros ya lo conocíamos y no extrañamos el cambio de dirección, nuestras actividades se modificaron y acoplaron sus nuevas ideas. En este sentido, tanto los profesores veteranos como don Santiago Pellejero, don Pedro Asirón, don José Luis Nieto o el que subscribe, como los recién incorporados: las profesoras doña Carmen Martínez, doña Julia Blasco, don Luis Azúa, don Jaime Whyte y doña Ana Torres, revitalizaron vigorosamente las actividades de la cátedra.

En la esfera docente procuró que se impartieran las clases a los alumnos por profesores especializados en los distintos campos de la Anatomía, incluso se organizaron conferencias por ilustres especialistas de fuera de ella. También tuvo gran éxito la modificación de las clases prácticas de disección y en los laboratorios, y se les estimuló para colaborar y desarrollar sus aficiones personales, como el dibujo, la estadística e informática. El radiólogo doctor Gómez Pereda colaboró con él en su Anatomía Radiológica.

Con la instauración de las tesinas de licenciatura, los alumnos se prepararon para un posible futuro como investigadores.

Los cursos de doctorado que se ofrecieron, buscaban responder a las inquietudes de los futuros médicos, y así se establecieron los de Anatomía Artística, Biomecánica, Anestesia regional y local, Citología y Antropología que, posteriormente, se incorporó 
como materia curricular, además de los clásicos de disección y reconstrucción embriológica, para los que se utilizó ampliamente la gran colección de embriones y fetos del laboratorio y museo anatómicos.

Todas estas actividades cristalizaron en una serie de tesis doctorales y trabajos que se llevaron a reuniones y congresos de distintas especialidades, y que se publicaron en numerosas revistas.

Y para terminar, debo agradecer al doctor Sarrat, el afecto y cordialidad que, me dispensó en todos los momentos de nuestra vida en común, sobretodo, por la ayuda en mis tareas al intentar compaginar mi vida asistencial por un lado y la docente por otro, cosa que hubiera sido imposible con otro jefe. Estas atenciones se hicieron notar muy ostensiblemente, en el momento de mi jubilación, el año 2002, con el homenaje que me organizó con todos mis compañeros, ofreciéndome su cálida simpatía y perenne amistad, que todavía perdura.

Por todos estos motivos, querido René, y con todo mi agradecimiento, te ofrezco este modesto recuerdo, en el momento de tu retirada a la vida privada, y a tu mujer, la profesora Torres y a tus hijos, que sepáis que podéis contar siempre con el agradecimiento de vuestro compañero y amigo.

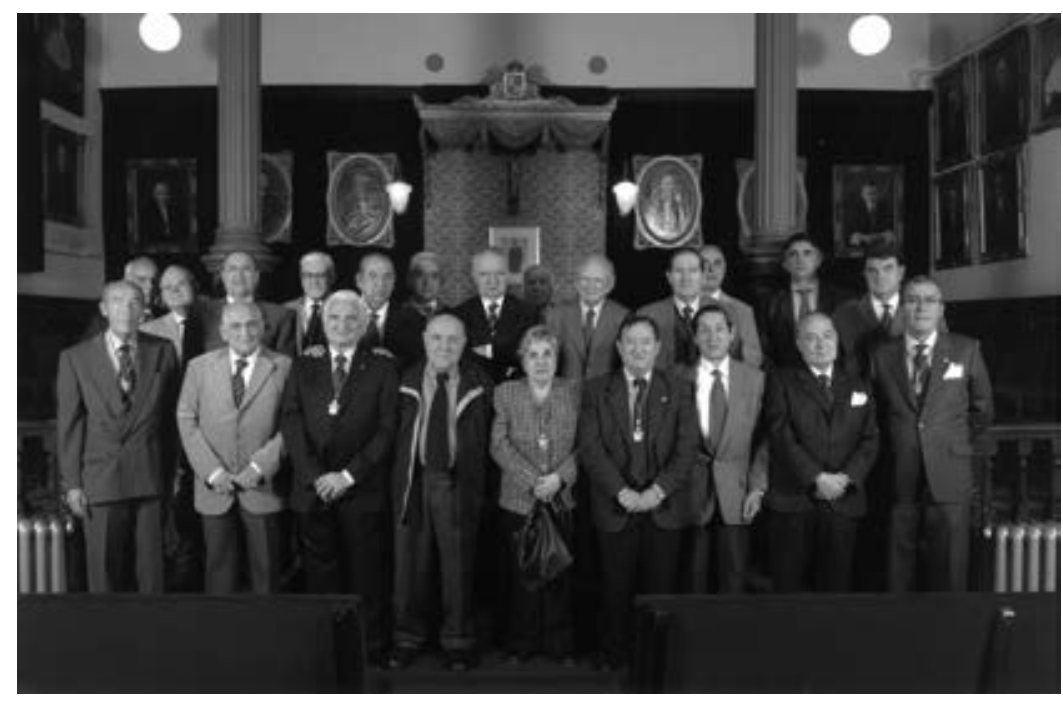

Miembros de la Real Academia de Medicina de Zaragoza 


\section{AL PROFESOR RENÉ SARRAT}

José Luis Lancho AlONSO

Catedrático de Anatomía Humana y Neuroanatomía

Director de Departamento. Departamento de Ciencias Morfológicas

Facultad de Medicina de Córdoba

María S. Poblador FernándeZ

Profesora titular de Ciencias Morfológicas

Facultad de Medicina de Córdoba

Querido, admirado y respetado René:

Recuerdo, como si fuera hoy mismo, aquel día del mes de octubre de 1971, a las 8 de la mañana, cuando después de atravesar el edificio principal de la Facultad de Medicina en la Plaza de Basilio Paraíso, llegué a la puerta del Departamento Anatómico. Después de unos segundos de espera - que me parecieron interminables- mientras abrían la puerta, pregunté por don José Escolar.

Después de atravesar la sala de disección, accedí a los despachos y laboratorios. Recuerdo que la taquicardia era grande.

Fui conociendo - me presentaron—a todos los miembros docentes y técnicos del departamento.

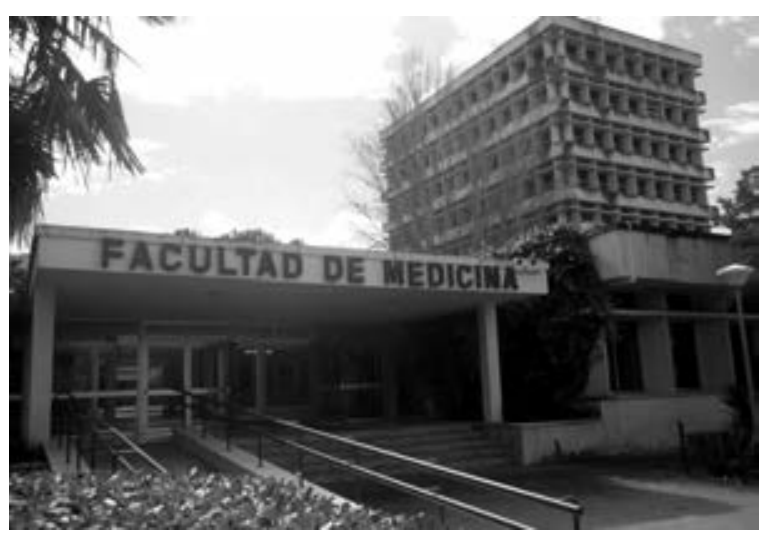

Facultad de Medicina de Córdoba 
Lo recuerdo perfectamente. Cuando René Sarrat me saludó, tuve una sensación de calidez humana grande y mi estado de ansiedad disminuyó considerablemente. Recuerdo su receptividad.

Mi estadía en el departamento fue tan agradable que hasta estuve tentado de dejar mi querida Salamanca para ubicarme en Zaragoza.

Tuve la oportunidad de dar mis primeras clases teóricas de Embriología y Anatomía; en concreto, la primera lección teórica de Anatomía que impartí fue el grupo de René: el sistema neuromuscular del ciático mayor y ramas colaterales del plexo sacro.

Cuando don José me asignó la lección, encomendó a René la supervisión y «control de calidad». Las reuniones que tuve, el ensayo que controló, me afianzaron en la idea que tenía: René era poseedor de una cualidad que solo tienen algunos elegidos, la confianza, la amistad y la calidez que emana e impregna siempre, no solo la relación personal sino también su magisterio.

En aquel vetusto, y sin embargo importante y cálido Departamento Anatómico, pasé una buena temporada. Todos me considerabais uno más del grupo. Y René fue un apoyo importante; siempre estaba dispuesto a atender lo que solicitaba y el resultado siempre era positivo, agradable, afable y salía de la reunión con una moral alta y la autoestima por las nubes.

Desde esa época arranca la corriente afectiva y amistosa que, aún sin vernos con frecuencia, se ha mantenido y se mantendrá siempre, incluso acrecentada tanto por Ana como por María, importantes e imprescindibles copartícipes de nuestra vida familiar y profesional. Entre María y tú hubo una especial comunicación y una corriente afectiva y de camaradería.

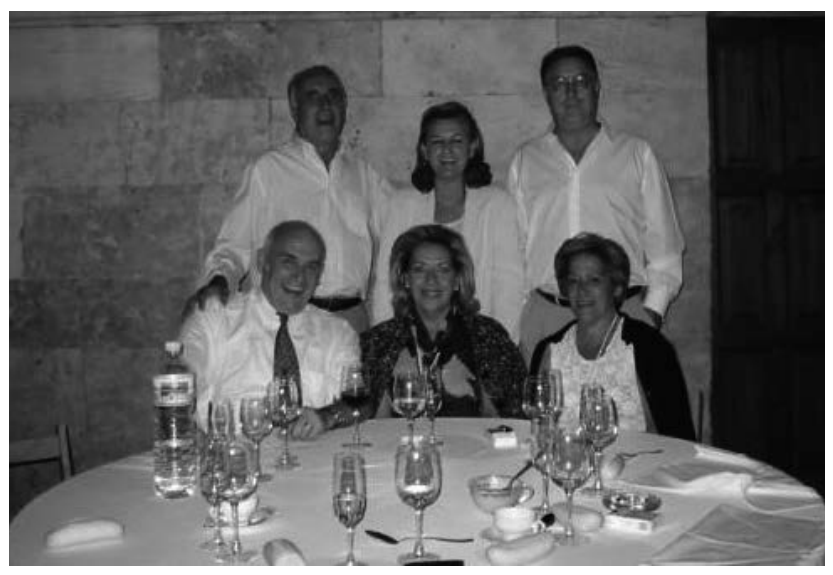

P. Mestres, R. Sarrat, A. Torres, Sra. de Lancho, J. L. Lancho, Sra. de Mestres 
Todavía guardo como «oro en paño» las lecciones de embriología y anatomía que, impresas en multicopista y encuadernadas en azul marino (precursoras del libro de Anatomía de Escolar), me regalaste antes de regresar a Salamanca una vez que cumplí los objetivos. Dijiste en aquel momento, «toma, esto para ti, que sabrás aprovecharlo». Casi sin palabras, solo pude decir un simple «gracias, René».

Desde entonces hasta ahora, siempre hemos tenido encuentros muy gratos y felices, tanto en los congresos como convenciones, reuniones o las afortunadas tesis doctorales que siempre han permitido continuar con la amistad y el afecto, incluso trasladado a nuestros hijos.

Si eso es importante, mucho más es el hecho de saber, sin lugar a duda alguna, que René estaba siempre ahí, no importó el tiempo transcurrido entre llamadas telefónicas o encuentros, no importaba el tiempo, siempre estabas ahí, querido y respetado René, y sé que siempre estarás.

Me resulta difícil expresar los sentimientos que tanto a María como a mí nos hace sentir la pareja Ana y René.

Sabes, vosotros sabéis, el especial cariño y amistad que tenemos hacia vosotros. Y también que nos sentimos orgullos y agradecidos.

Simplemente, un abrazo.

Córdoba, septiembre de 2008. 


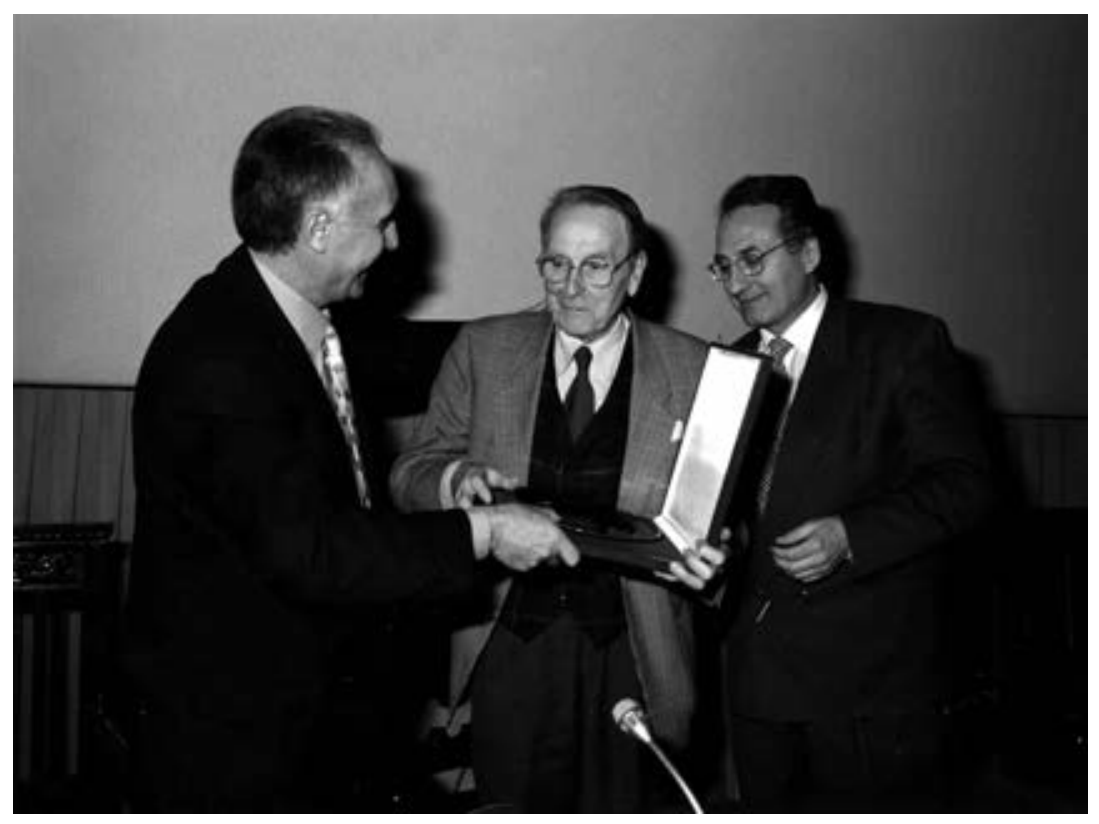




\title{
LADRONES DE CEREBROS
}

\author{
SANTIAGO RODRÍGUEZ \\ Catedrático de Anatomía. Facultad de Medicina. Universidad de Valladolid
}

A René Sarrat, que es unos meses mayor que yo, lo conocí en octubre de 1959. Durante más de doce años, hasta que ganó la cátedra de la Facultad de Medicina de Bilbao, tuvimos una relación de amistad muy estrecha fruto de nuestra convivencia en la cátedra (entonces no eran departamentos) que dirigía don José Escolar.

En el Colegio Mayor Pedro Cerbuna, donde nos alojábamos, ya lo empecé a tratar debido a su condición de Alumno Interno de Anatomía. Para entender esta situación, es necesario saber que llegué a Zaragoza, cuando estudiaba cuarto curso, siguiendo la estela de don José que se trasladó desde Granada —-donde comencé a estudiar la carrera- a Zaragoza en el año 1959.

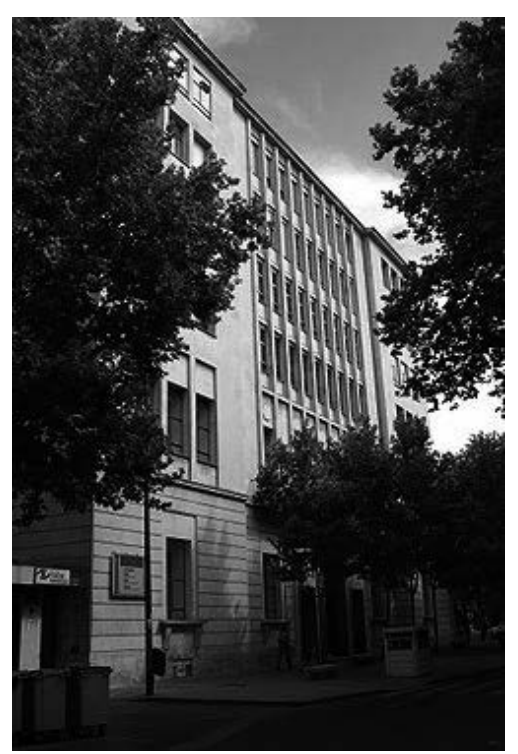

Facultad de Medicina de Valladolid 
Don José, que arrastró desde Granada a varios jóvenes anatómicos (Víctor Smith, Pedro Amat, José M. ${ }^{a}$ Smith, Vicente Calatayud, Elvira Ferres, Inés Fernández y yo mismo), se encontró al llegar a Zaragoza con otro anatómico en ciernes pero de formación clásica. René ya demostró desde ese momento su gran capacidad de adaptación, pues se convirtió en un acérrimo de la anatomía funcional que nuestro maestro nos enseñaba e inculcaba empleando su gran carisma.

En el Colegio Cerbuna hacía una vida bastante apartada. Se relacionaba especialmente con Edo, un compañero que creo hizo psiquiatría. En aquellos tiempos de colegial, siempre me llamó la atención la sobria vida de un hombre tan brillante y simpático. Es posible que sus circunstancias personales condicionasen este comportamiento, permitiéndose pocas distracciones mientras se labraba el porvenir, como decíamos entonces. En el Cerbuna, la primera imagen que tengo de René es con un jersey blanco de cuello alto; jovial pero serio y bien considerado por todos los colegiales. Su vida retirada la achacábamos, como ya he dicho, a su dedicación al estudio.

En 1961 acabó la carrera y se dedicó a la anatomía. A partir de ese momento nuestro trato se intensificó puesto que yo era un Alumno Interno que participaba bastante en labores de cátedra, especialmente en la disección. En 1963 me licencié y entré a formar parte del grupo de don José Escolar. Nuestra amistad y mutuo conocimiento fue aún más estrecho; aunque, como es sabido, nunca se conoce a nadie en profundidad, ni siquiera a uno mismo.

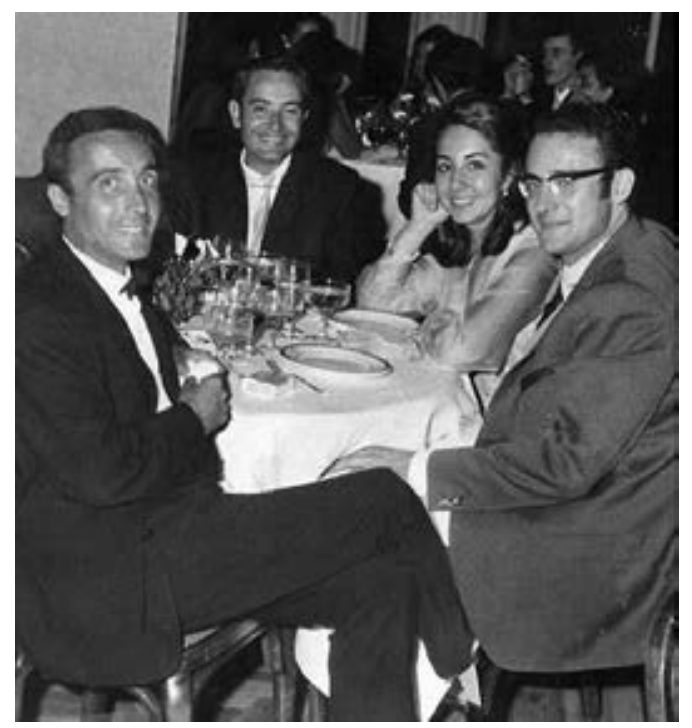

Santiago Rodríguez en compañía de René Sarrat 


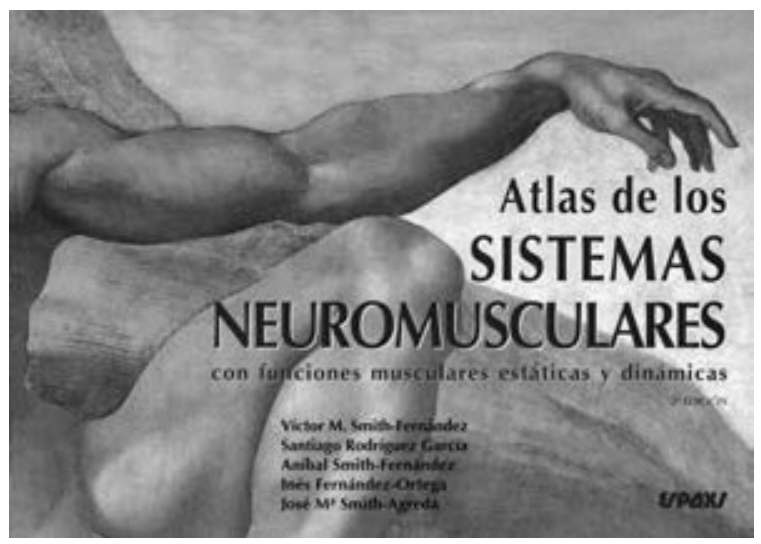

Unos meses antes de que yo acabase la carrera, Víctor Smith y Pedro Amat ganaron las oposiciones y se marcharon a Valencia y Salamanca, respectivamente. Elvira nos dejó también, al marchar con Víctor a Valencia, y Vicente Calatayud se orientó hacia la neurocirugía. José M. ${ }^{a}$ Smith, René Sarrat y yo formamos un trío de amigos fuertemente ligados por el trabajo. Se podría decir que la dedicación y apego a la anatomía esculpió nuestra amistad. Llevábamos una vida de mucha concentración, parecida a la de los seminaristas, pero lo nuestro no era la teología sino la anatomía. Pedro Mestres, más joven que yo, también tuvo durante un tiempo inquietudes parecidas a las nuestras; al poco, sin embargo, deseó y consiguió ser histólogo. Inés trabajaba con nosotros, pero en aquel tiempo simultaneaba la anatomía con el cuidado de sus hijos.

En aquellos años yo aprendía mucho de José M. ${ }^{a}$ y de René, que era, de los tres, el más inquieto y apasionado. El hombre sosegado que conocí en el Cerbuna, no tenía nada que ver con la persona reivindicativa y brillante que ahora tenía ante mí. Probablemente, el que mejor conoció al René de esa época fue Pedro Mestres, quien podría relatar las excursiones que se hicieron por los vanos de la Sala de Disección para soltar contra las bovedillas del falso techo la justa rabia que nos embargaba al ver que las cosas no iban tan bien como deseábamos. En estos años descubrí a un René atractivo, con capacidad de liderazgo y gran éxito como profesor. Ya no era el colegial reservado del Cerbuna que aplicaba toda su energía a los estudios de la carrera.

Me invitó a su casa en Gimenells, pueblo leridano ligado a la Concentración Parcelaria de los años cuarenta y cincuenta. Allí conocí a su madre, ya viuda, que me acogió muy bien en su casa. Sabía perfectamente que su hijo y yo íbamos escasos, por lo que tanto en el pueblo como después, cuando la veía en Zaragoza, mostraba la ternura que a una mujer buena y curtida le despierta la lucha que los jóvenes llevan a cabo para abrirse paso en la vida. En el pueblo conocí a familiares suyos, entre los que destacaba su abuela que vivía con ellos; hablaba catalán y poco castellano. A Nélida, su hermana, ya la conocía por ser estudiante de medicina. 
Cuando casé con Enriqueta, en el año 1967, René aún seguía soltero. Enriqueta, a pesar de no ser anatómica, tenía muy buenas relaciones con los miembros de la cátedra, entre los que estaba Ana que algunos años después casó con él. Es difícil saber cómo es la vida de un matrimonio, pero me da la impresión de que René tiene en Ana uno de sus mejores activos.

Quiero acabar con un suceso dramático que es el responsable del título de este escrito; dicho título, aunque menos literario pero más anatómico, debería ser el de Ladrones de Encéfalos. Extraer encéfalos era una acción furtiva que practicábamos de vez en cuando a los cadáveres que desde el Hospital Clínico pasaban al Depósito hasta su entierro. Aprovechábamos ese escaso tiempo para obtener tan codiciado material que después se utilizaba en prácticas o en investigación. La técnica que nos enseñó don José consiste en una incisión profunda desde una región temporal a la otra pasando por la región occipital, pero respetando los músculos temporales. Después, como si fuese un scalp, se arrastra el cuero cabelludo hacia delante hasta dejarlo como un colgajo que tapa el rostro. Se rechazan los músculos temporales hacia abajo y se sierra el cráneo. Tras cortar la paquimeninge, excepto en su parte posterior, y desinsertar la hoz del cerebro de la apófisis cresta de gallo se rechazan dichas membranas hacia atrás. Queda así el encéfalo al descubierto pero aún tapizado por la aracnoides. Con las yemas de los dedos se levantan los lóbulos frontales y se cortan los primeros nervios craneales y las carótidas internas. Para llegar a los últimos pares craneales y al tramo final de los senos sigmoideos, es preciso cortar la inserción de la tienda del cerebelo en el borde superior del peñasco. Por fin, se introduce el escalpelo en la parte superior del conducto raquídeo y se secciona la médula espinal. Haciendo así las cosas, se rompe el tallo hipofisario, por lo que la glándula queda atrapada en la silla turca. Para evitarlo es necesario extraer en su totalidad la silla turca utilizando cincel y martillo; con esta acción, bastante delicada, se asegura la integridad del hipotálamo, tallo hipofisario e hipófisis. Se reponen meninges y calota, la cual se fija con una cuerda fina que va de un músculo temporal a otro. Por último, se coloca en su sitio el cuero cabelludo y se dan puntos con hilo negro o blanco, según el color del cabello, para que no se note la compleja maniobra que se ha llevado a cabo. Estas maniobras, que he descrito con cierto detalle, las hacía René con gran soltura, especialmente el golpe de cincel para extraer la silla turca.

Pues bien, una tarde avisan de que hay un cadáver. Pasamos René yo al Depósito y empezamos las maniobras descritas. Cuando estaba el encéfalo descubierto y nos disponíamos a su extracción, de manera inesperada se abre la puerta y entran dos empleados de la funeraria. No tuvimos la precaución de cerrar la puerta desde el interior. Uno de ellos empezó a lanzar las blasfemias más horribles que he oído en mi vida. Se había dado la tremenda casualidad de que en Zaragoza, una ciudad, entonces, con más de trescientos mil habitantes, en aquel preciso día, en aquella precisa hora en que dos jóvenes anatómicos extraían el encéfalo a un cadáver, el empleado de la funeraria encargado de enterrarlo era su íntimo amigo. El momento fue de una tensión terrible, casi llegamos a las 
manos. Tuvimos que resolver la situación con mucho arrojo y energía. René, además de inteligente, trabajador, metódico..., es valiente. Aquel hombre, cuya cara expresaba una extraña mezcla de furor y dolor, que nunca he vuelto a contemplar, nos dijo: «pronto les sacaré yo de aquí metidos en esta caja». No sé si fue una maldición o el anuncio de una venganza. Ninguna de las dos cosas se ha hecho realidad y gracias a Dios estamos a punto de jubilarnos felizmente.

Salud, René. 


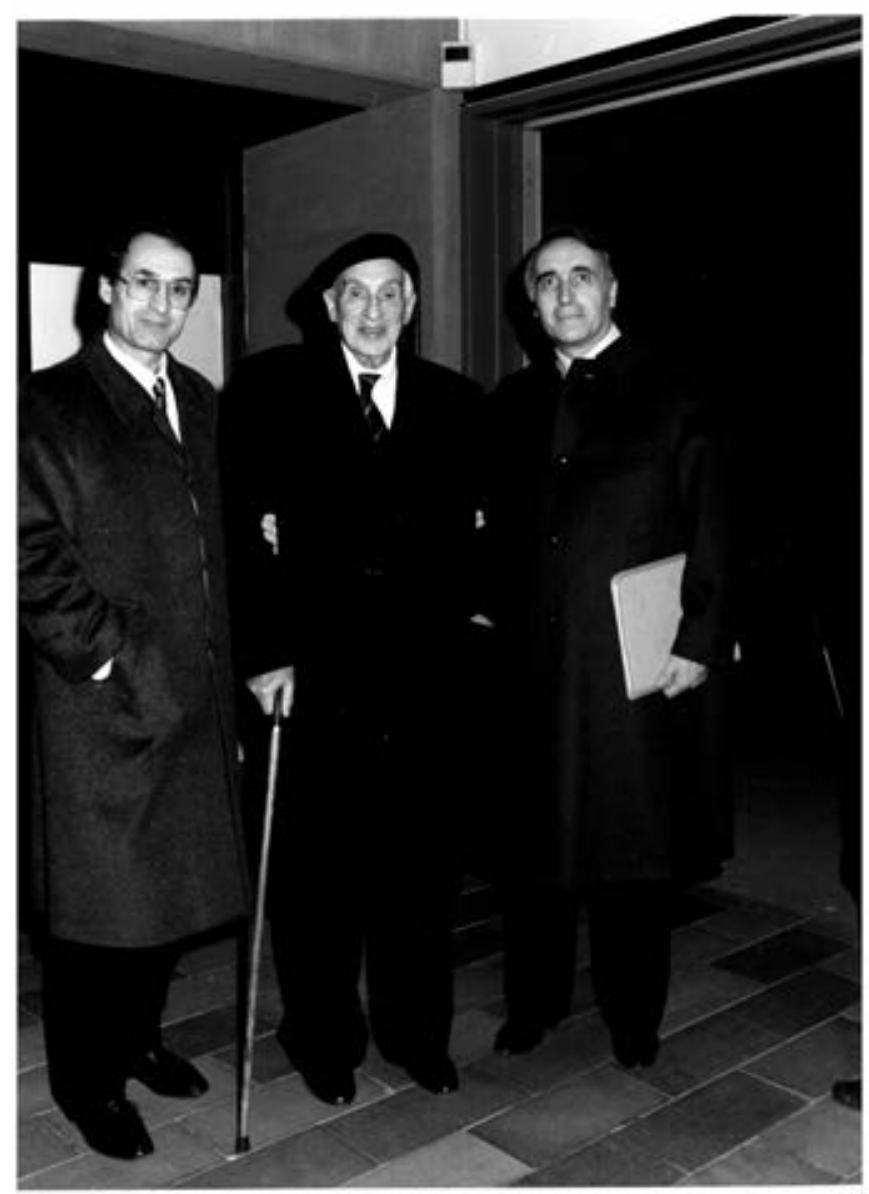




\section{AL PROFESOR RENÉ SARRAT}

Miguel Ángel Crovetto de la Torre

Catedrático de la Universidad del País Vasco

Académico de Número de la Real Academia de Medicina del País Vasco

Juro por Apolo el Médico y Esculapio y por Hygeia y Panacea y por todos los dioses y diosas, poniéndolos de jueces, que este mi juramento será cumplido hasta donde tenga poder y discernimiento. A aquel quien me enseñó este arte, le estimaré lo mismo que a mis padres; él participará de mi mandamiento y si lo desea participará de mis bienes. Consideraré su descendencia como mis hermanos, enseñándoles este arte sin cobrarles nada, si ellos desean aprenderlo.

(Hipócrates: Juramento Hipocrático).

Hay circunstancias en la vida que le convierten a uno en un sujeto privilegiado. $\mathrm{Me}$ está pasando esto desde que Jaime Whyte, el discípulo predilecto y más cercano del profesor Sarrat, me pidió que escribiera unas líneas recordando todo lo que nosotros, sus discípulos, vivimos y sentimos con el insigne don René, maestro y faro de decenas de discípulos apasionados.

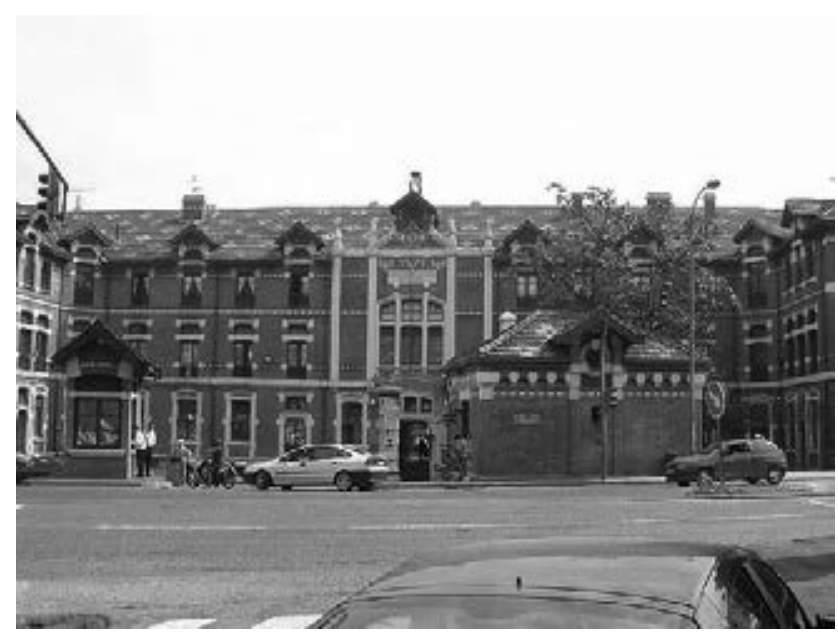

Hospital de Basurto. Bilbao 
Permítanme recordar algunos antecedentes que sucedieron en la época en que conocí al profesor Sarrat: Corría el año 1972 y aquel otoño llovía en Bilbao cada día, como si nada pudiera cambiar aquel destino gris de la meteorología. Los alumnos de la cuarta promoción de la Facultad de Medicina de Bilbao habíamos superado el primer curso de la carrera, milagrosamente, considerando que las huelgas de estudiantes habían sido brutales y que la docencia académica se había limitado a una o dos semanas lectivas. Éramos unos jóvenes libérrimos, y descarados, hijos de una época turbulenta de nuestra historia. Aún así, solo los razonablemente estudiosos superamos la terrible criba de aquella selectividad que fue la hecatombe del $80 \%$ de los matriculados el año anterior. Aquella muchachada estaba formada por alumnos autodidactas que no conocíamos la Academia y no entendíamos la figura de un Maestro, a pesar de haber pasado un año en la Facultad de Medicina, amada y despreciada al tiempo. Empezábamos a sentirnos descreídos con la universidad aunque aún albergábamos alguna esperanza de que aquella carrera que habíamos elegido y aquella Facultad en la nos habíamos matriculado sirviera para algo más que para inflingirnos aquella sensación desangelada. La arquitectura del edificio que nos cobijaba, situado en el monte, alejado de toda población y exento de calor humano y físico, no ayudaba en nada a mejorar nuestro ánimo.

Aquel año, estrenábamos un anfiteatro en la nueva Facultad de Medicina, en Lejona que, los más, deseábamos usar para algo que no fuera una asamblea de huelguistas. Esperábamos ansiosos en cierto modo, porque jal fin! íbamos a estudiar Medicina, lejos ya de las asignaturas comunes y aburridas del curso selectivo anterior. Aquel día empezaban las clases de Anatomía, esa asignatura que encerraba en su palabra el peso mágico de lo temido y deseado, casi sagrada. Los chicos ocupábamos ruidosamente el aula, acostumbrados como estábamos a la algarabía libérrima. Nadie sabía nada de aquel nuevo, joven, y flamante catedrático que se estrenaba como tal en nuestra Facultad. Un enigma. Se abrió la puerta del aula empujada por el bedel, enjuto y seco, que trabajaba en la cátedra y entonces llego Él, como una luz poderosa. Un hombre alto, pulcro, bien parecido (las compañeras lo llamaron divino), elegante, y de mirada inteligente. Guardó silencio hasta que callamos todos, algo hechizados por su presencia hermosa. Tomó la palabra y empezó, con una dicción segura y un verbo mimoso, a dirigirnos sus primeras frases. Había algo mágico en él. Los alumnos, descreídos muchos, callaron sorprendidos ante aquel hombre que parecía saber la canción de la comunicación como sabe un tenor afinadísimo entonar su aria más hermosa, deslumbrando desde la primera nota. Tomó luego su tiza, sin detener su discurso, y se acercó al encerado negro y grande, como una tierra vacía; por arte de magia empezaron a nacer de las entrañas vacías de la pizarra figuras hermosas que, a la voz creadora del profesor, afloraban vivas como granjas fértiles. El pasmo de los alumnos fue absoluto y respondimos todos con nuestro silencio absorto y emocionado. ¡Era eso! ¡Claro! ¡Eso era un maestro! Ahora sabíamos lo que era una Facultad de Medicina. Por fin, se colmaba nuestra emoción necesaria. 
Algunos de nosotros fuimos más tarde sus alumnos internos. Nos acercamos a él con devoción discente y pasmada ante tanto saber, ante tanta frescura intelectual, entregados a su magisterio como hijos en busca de un progenitor sabio. Nos acogía René con el mismo afecto limpísimo que rigor en el quehacer indicado. Nos enseñó el camino correcto del deseo de saber. Siempre más. Nunca bastante.

Años más tarde, ya con la carrera terminada fui profesor asociado de Anatomía en su cátedra y recuerdo con qué paciencia sabia, que no infinita, se sentaba a solas conmigo en un aula vacía, y me exhortaba a exponer la clase que yo había preparado y debía dar a los alumnos en el aula de Anatomía. Corregía mis dibujos, para mejorarlos y hacerlos más comprensibles, me proponía cambios para hacerla más amena y me animaba finalmente a ir al aula (la jaula de leones me parecía a mí) con tranquilidad porque decía «estás preparado». ¿Se puede pedir más a un maestro?

Yo mismo y otros colegas jóvenes fuimos instruidos por el profesor Sarrat, en el desarrollo de trabajos de investigación. Nos enseñó a hacer nuestros primeros experimentos con animales, a seleccionar cuidadosamente los métodos de trabajo, insistiendo en que no habrá resultados válidos si los métodos no eran rigurosos y a discutir con inteligencia esos resultados. Fruto de aquellos estudios son muchos de nuestros primeros trabajos y muchas de nuestras tesis doctorales. ¡Qué sana paciencia! ¡Qué caballerosidad científica! ¡Qué hombría de bien más generosa la de don René!

Tuve, en mi tiempo juvenil, dificultad para escribir y leer mi tesis doctoral y no por falta de interés o trabajo. El destino me creó enemigos, seguramente justificados, que hacían difícil o imposible acabar esa empresa. El Maestro, René, ya no estaba en Bilbao sino en su Zaragoza amada y allí fui yo a pedirle consejo y ayuda. Me escuchó y me miró como solo él sabía hacerlo. Me invitó a su casa, y comió conmigo y su esposa. Me entendió y me tendió su mano, aunque eso le supusiera oponerse a fuerzas de peso en aquel entonces. Y es mi mayor orgullo científico haber sido su doctorando porque su magisterio supo darle a mi tesis un valor triple: el científico y el paternal ante el hijo que sufre problemas, y una lección a no olvidar: La razón la tiene quien la tiene, y hay que protegerla al coste que sea.

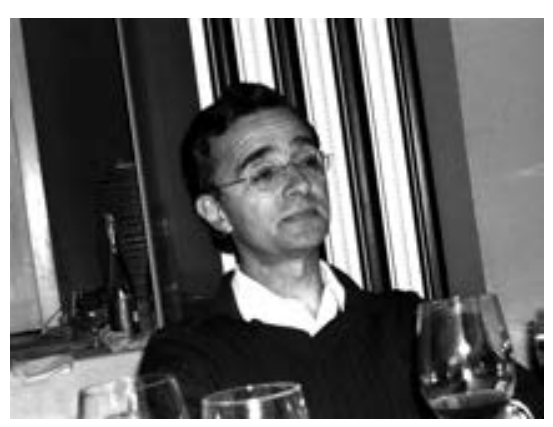

Miguel Ángel Crovetto 
Muchas veces, posteriormente, tuve la ocasión de invitar al profesor Sarrat a dar conferencias, casi cada año, en la Academia de Ciencias Médicas de Bilbao. En cada ocasión el aula de conferencias se llenaba de ex alumnos que abarrotaban la sala, médicos prestigiosos muchos de ellos. Todos añoraban su magisterio, aunque el tema que tratara nada tuviera que ver con su actividad profesional, tal era el gancho que con sus discípulos tiene el maestro. Más de un colega se ofendió conmigo porque olvidé llamarle para informarle de la organización de alguna de aquellas memorables conferencias. ¿Qué tiene este hombre que los demás no tenemos? ¿Cómo se llega a esa perfección en la comunicación? Os lo voy a decir, en secreto: Está tocado por la mano de Dios. No hay otra explicación.

En nuestro devenir con el maestro, don René Sarrat Torreguitart, hemos aprendido a quererle con afecto real e intenso. Si la distancia nos ha mantenido alejados no ha estado el corazón huérfano de afecto por ello. Le debemos mucho. Y se lo voy a decir. Te queremos, Maestro, te queremos, amigo, te queremos, padre.

Nuestro beso puro, como la verdad, para ti. 


\title{
RENÉ, PALABRA Y MAGISTERIO
}

\author{
J. V. LAFUENTE \\ Catedrático de Anatomía y Embriología Humanas. Departamento de Neurociencias \\ Facultad de Medicina y Odontología. Universidad del País Vasco
}

José Luis Arsuaga refiere en «El collar del Neandertal» la trascendencia de la palabra en la adquisición de humanidad; leyendo estas líneas recordé cuando, hace ya unos años preparando las jornadas de «Didáctica de las Ciencias Morfológicas», le propuse a René hablar sobre el papel que juega la palabra en la enseñanza de la Anatomía Humana.

El aceptó y comenzó la presentación captando inmediatamente la atención del auditorio con «Al principio era la palabra y la palabra era DIOS» (S. Juan 1,1). Tal es la importancia del «verbo» que tiene como misión comunicar y transmitir mensajes y que es uno de los signos de identidad más específicos del ser humano (Fig. 1).

La anatomía es el estudio de estructuras producto y sustrato de una función, de un desarrollo, de una teleología. René domina la palabra y la comunicación, lo que junto a sus profundos conocimientos anatómicos le ha permitido ser un docente excepcional, y por su espíritu innovador e iconoclasta, un universitario de su tiempo.

Le conocí en los cursos de doctorado de 1983, y en 1987 presidió el tribunal de mi tesis doctoral. Era final del verano en Zaragoza, hacía calor, la corbata apretaba y el traje pesaba como solo lo hacen en esas ocasiones; pero René con su talante desenfadado y, sin que el acto perdiera un ápice de rigor académico, consiguió generar un clima agradable.

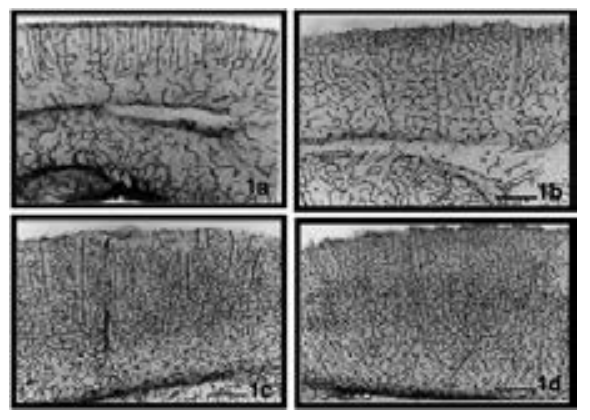

La serie de fotografías (1a, 1b, 1c y 1d) muestra la malla vascular en 4 momentos del desarrollo $(0,7,14$ y 21 días postnatales, respectivamente), histoquimia para Butiril colinesterasa en secciones de $60 \mu \mathrm{m}$ de grosor, barra $250 \mu \mathrm{m}$. 
Con el paso de los años hemos tenido ocasión de compartir mesa en tribunales y congresos, y aprovecho para manifestarle lo que quizá en alguna ocasión le haya dicho: «profesor, no es solo un placer, es un honor compartir estas actividades con usted, su buen hacer nos enseña y nos hace más capaces».

En la docencia de las ciencias experimentales no se trata solo de enseñar lo que se descubre, sino de hacer sentir en toda su intensidad la emoción que experimentamos en el proceso.

Enseñar, además de preparación, estudio, conocimiento, técnica..., requiere una actitud y capacidad personal para sintonizar con los demás. Enseñar es un acto de entrega, un desdoblarse, un superarse cada día para dar lo mejor de uno mismo, esta es la esencia del éxito de René.

El profesor Sarrat conoce todas las estrategias o como él las llama «picardías docentes» para captar la atención del auditorio (anécdotas llamativas, casos clínicos expresivos, inflexiones de voz...). En su discurso tan importante como lo que dice es lo que no dice, su manejo de las pausas y los silencios.

Una descripción ordenada, con el adecuado énfasis en cada parte interpreta y confiere sentido a las obras de arte, entre las que sin duda se encuentra el objeto formal de la ciencias médicas.

En cierta ocasión le oí a René una anécdota de don Gregorio Marañón, a quien cuando le preguntaron qué aparato había contribuido más al desarrollo de la Medicina contestó: «La silla, aquella que da el sosiego necesario para fraguar una corriente de confianza entre el paciente y su médico».

Sin duda el buen uso de la palabra por parte de René ha contribuido significativamente a suscitar y encauzar muchas vocaciones en los más diversos ámbitos de la ciencia.

Gracias por su magisterio, Profesor.

Y qué mejor homenaje a un colega que dedicarle el fruto de nuestro trabajo.

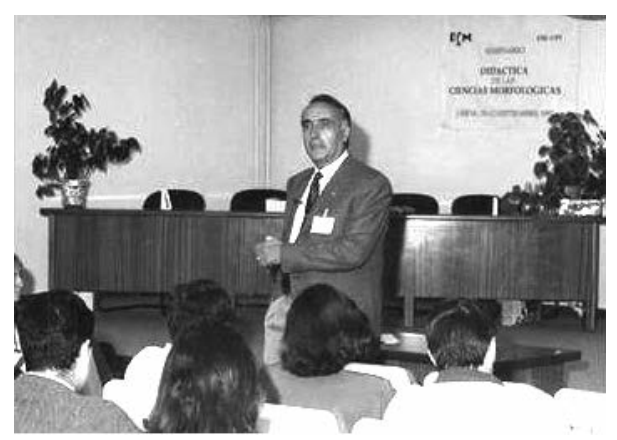

René en una de sus intervenciones en las jornadas de «Didáctica de las Ciencias Morfológicas». Leioa, septiembre de 1992

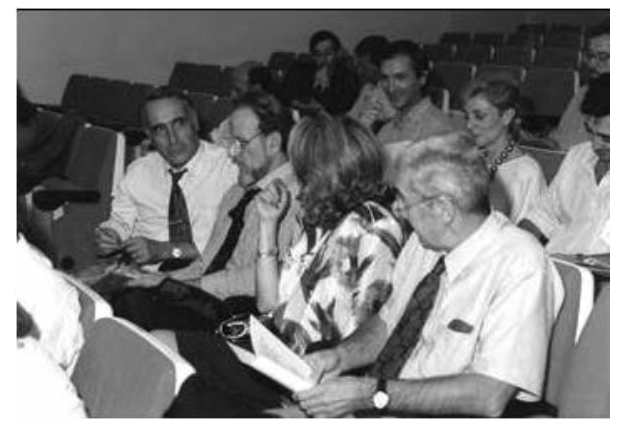

René acompañado de Ana, José M. ${ }^{a}$ Smith y Radijov Krstic 


\section{DESARROLLO POSTNATAL DE LA VASCULARIZACIÓN DEL CÓRTEX VISUAL}

José-Vicente Lafuente y Enrique G. Argandeña

\section{Introducción}

El desarrollo postnatal del Sistema Nervioso Central (SNC) se encuentra modulado por la experiencia que induce un aumento de la actividad neuronal, lo que conlleva un aumento de la actividad metabólica con un incremento en los requerimientos de energía. Este hecho implica el establecimiento de unos cambios adaptativos que satisfagan las demandas de la nueva situación.

La vascularización de la corteza presenta características diferenciales con otras áreas del cerebro y del resto del organismo, así, un $90 \%$ de la vascularización cortical está constituido por una fina red capilar que se extiende por todo el córtex. El sistema vascular de la corteza cerebral de rata se organiza a partir de los vasos que penetran perpendicularmente a la superficie, procedentes del sistema vascular leptomeníngeo. Estos troncos vasculares se ramifican formando la red capilar que constituye el sector nutricional fundamental de la corteza, sin embargo, el intercambio metabólico tiene lugar también en sectores de la microcirculación anteriores a la red capilar, en arteriolas de pequeño calibre.

El desarrollo del sistema vascular de la corteza cerebral se establece en íntima relación con la población y actividad neuronal estando la densidad vascular en relación directa con la actividad metabólica local y el consumo de oxígeno de las diferentes regiones corticales. En zonas que presentan una mayor actividad, se observa un incremento de la densidad capilar.

Las diferencias en la densidad capilar entre distintas áreas se deben fundamentalmente a la densidad y actividad neuronal y/o sináptica. Partiendo de zonas estructuralmente similares, las diferencias están en función de la mayor o menor actividad. El desarrollo del lecho vascular tiene lugar como consecuencia del desarrollo de la corteza y discurre paralelamente al mismo. De este modo, en las especies animales en las que la corteza cerebral no se encuentra plenamente madura en el nacimiento, existe una escasa vascularización cortical, a medida que madura el córtex se va desarrollando su arquitectura vascular. Esto no sucede en especies inferiores que nacen relativamente maduras en las que podemos apreciar una red vascular cerebral similar al animal adulto. 


\section{Desarrollo}

\section{Vascularización de la corteza cerebral}

El primer esbozo de vascularización cerebral lo forman los vasos craneales que, partiendo de los arcos aórticos, se acercan a la porción ventral del tubo neural formando un plexo vascular primordial. Los vasos procedentes del plexo primordial alcanzan las vesículas telencefálicas y, a medida que avanza la diferenciación neural, las yemas vasculares penetran perpendicularmente en las paredes del tubo nervioso. El desarrollo de la vascularización cerebral se divide en dos etapas, una extracerebral y otra intracerebral.

Los vasos arteriales y venosos que cubren la corteza cerebral se forman a partir de plexos capilares indiferenciados. En un principio disminuye la densidad de las arterias leptomeníngeas y posteriormente de las venas, lo que indica que el sistema venoso alcanza su patrón definitivo con posterioridad al arterial.

La vascularización de la corteza cerebral se inicia con el desarrollo de troncos vasculares penetrantes perpendiculares a la superficie cortical. El desarrollo de estos vasos se inicia en los primeros días de desarrollo embrionario y se completa en la vida postnatal.

Los primeros brotes vasculares penetran en la corteza antes del desarrollo de la placa cortical, por lo que los primeros vasos perpendiculares alcanzan la zona ventricular opuesta al plexo leptomeníngeo. Los vasos que surgen durante el desarrollo de la placa cortical penetran en esta. Este hecho se refleja en la estructura vascular de la corteza adulta, donde podemos distinguir los troncos radiales que se originaron en un primer momento ya que atraviesan todas las capas corticales sin tener apenas ramas colaterales. Durante el desarrollo de la corteza, el sistema vascular leptomeníngeo emite nuevas ramas vasculares que penetran en la placa cortical abarcando un territorio que se corresponde con su antigüedad de tal forma que los primeros vasos irrigan las capas más profundas y los más modernos las capas más superficiales. En la rata, a partir de la segunda semana de vida postnatal no se observan nuevas proliferaciones vasculares procedentes del sistema leptomeníngeo que penetren perpendicularmente. El volumen y área superficial de la corteza cerebral continúa incrementándose por lo que la densidad de los vasos penetrantes perpendiculares desciende en relación a la superficie cortical.

La corteza cerebral, además de engrosar, experimenta un crecimiento tridimensional acompañado de un proceso de arborización vascular, a partir de los vasos penetrantes. Al igual que ocurría con el crecimiento en grosor, los vasos más antiguos presentan una mayor ramificación horizontal que se traduce en el hecho de que estos vasos ocupan un mayor territorio.

Tras la maduración capilar no se observan nuevas gemaciones de ramos vasculares, lo que indica que el proceso de gemación de nuevas ramas vasculares se culmina al mismo tiempo que se desarrolla por completo la pared vascular. La neoformación vascular se encuentra mediada por una variedad de citoquinas entre las que destaca el 
Factor de Crecimiento Vascular Endotelial (VEGF). Este factor, también conocido como el factor de permeabilidad vascular (VPF), es una proteína de $46 \mathrm{Kda}$ con cinco isoformas, siendo la formada por 165 aminoácidos (VEGF165) la que presenta la principal actividad mitótica, altamente específica de células endoteliales. Los dos principales receptores sobre los que actúa el VEGF son el flt-1 y el flk-1. La actividad mitótica endotelial se relaciona principalmente con el segundo de los receptores (flk-1), también llamado VEGFR-2. El VEGF165 ha sido igualmente relacionado con receptores ligados al desarrollo neuronal (neuropilina), ligando por tanto la neoangiogénesis con la plasticidad neuronal [7]. El mecanismo de secreción se ha propuesto que está desencadenado por la hipoxia tisular relativa lo que induce la secreción del VEGF por parte de los astrocitos.

Durante la primera fase del desarrollo vascular se establece un patrón básico que se adapta a las necesidades de cada área cortical mostrando diferencias regionales específicas en relación al ulterior desarrollo de las distintas zonas. Durante la segunda fase de la vascularización se produce un gran aumento de la densidad del lecho vascular terminal que se corresponde con un gran incremento de la superficie capilar estrechamente asociado al incremento de la demanda metabólica del tejido. Entre los días 8 y 20 de vida postnatal las células endoteliales de la microvascularización proliferan rápidamente. Es durante este periodo cuando se forma la práctica totalidad de las ramas vasculares. La actividad mitótica de las células endoteliales desciende bruscamente durante la tercera semana de vida postnatal, lo que se puede comprobar mediante la incorporación de timidina tritiada a las células endoteliales.

La tercera fase de desarrollo vascular consiste en la elongación de las ramas existentes. En un principio, se establecen las sucesivas divisiones vasculares y posteriormente los vasos crecen en longitud para abarcar la totalidad del territorio que les corresponde. Esta fase de elongación de los capilares preexistentes se extiende desde el día 20 hasta la edad adulta. Este es el patrón fisiológico de desarrollo. En animales criados en condiciones normales el patrón definitivo de la vascularización se culmina en la tercera semana de vida postnatal. Posteriores cambios en las demandas metabólicas locales transitorias son suplidos mediante cambios en el flujo local, pero existen circunstancias especiales en las que se producen incrementos definitivos de demanda metabólica que son compensados mediante la ampliación o adaptación del patrón normal de desarrollo.

Como hemos mencionado con anterioridad, el desarrollo de la vascularización discurre paralelo al desarrollo del córtex que irriga. Por ello, se distinguen diferentes patrones vasculares que se corresponden con regiones corticales distintas en cuanto a su origen filogenético (arqui-, paleo- o neocórtex).

Existe una relación directa entre la densidad vascular y la actividad metabólica. Esto se evidencia por la correlación entre la densidad vascular y la de mitocondrias. Igualmente se han correlacionado la densidad capilar local, la utilización local de glucosa y el flujo sanguíneo cerebral local. 


\section{El Sistema Visual}

El sistema visual es un sistema jerarquizado que cuenta con un receptor sensitivo, unas estaciones intermedias y un área especifica en la corteza cerebral. El hecho de que sea una vía bien conocida, con unas estaciones intermedias muy bien definidas y estructuradas y con fácil accesibilidad a cada uno de los componentes de la vía hace que sea un sistema frecuentemente elegido en los estudios sobre la corteza cerebral.

2.1. Estudios sobre la influencia de la experiencia en el desarrollo de la vascularización del córtex visual de la rata.

Muchos de los estudios sobre la influencia de la experiencia externa en el desarrollo de la corteza sensitiva han sido llevados a cabo en la corteza visual por sus características peculiares anteriormente apuntadas. Los efectos de la influencia de la experiencia visual se han estudiado en las dos situaciones antagónicas: el incremento de estímulos y la deprivación de los mismos.

a) Influencia de la experiencia compleja en el desarrollo de la vascularización de la corteza visual de la rata

Como hemos mencionado anteriormente, el patrón vascular de la corteza visual de la rata se encuentra completamente desarrollado al final de la tercera semana de vida postnatal. No obstante, es posible observar neoformación vascular en el caso de animales criados en un entorno que exige un aprendizaje complejo.

Durante las tres primeras semanas de desarrollo cortical, la densidad vascular refleja las demandas metabólicas locales culminándose el desarrollo vascular el día 21 de vida postnatal. A partir de esa fecha, se pueden producir aumentos puntuales de la demanda que se compensan con variaciones en el flujo vascular local. Pero existen otras situaciones en las que el aumento de la demanda metabólica se establece de un modo permanente. Esto se puede observar en el caso de ratas criadas en un entorno complejo que implica una mayor cantidad de estímulos visuales con el consecuente aumento de la conectividad sináptica. En estos casos se ha demostrado un aumento local de la vascularización pese a haber finalizado el periodo normal de desarrollo vascular. Si se estudia la corteza visual de ratas de 30 días de edad, fecha en la que el patrón microvascular se encuentra completamente establecido, se observa un incremento de la arborización dendrítica, de la ratio sinapsis/neurona y del número y tamaño de células gliales. Si no hubiera neoformación vascular, la densidad vascular sería mucho menor por el aumento relativo del resto de componentes. Esto no ocurre así, sino que la densidad vascular incluso es mayor, lo que sugiere un aumento del lecho vascular en respuesta al incremento de demanda metabólica.

Trabajos en los que se han comparado ratas normales con ratas criadas en un entorno complejo muestran una mayor densidad de ramificación vascular una menor distan- 
cia media de un punto del tejido al vaso más próximo, un aumento del diámetro vascular medio y una mayor superficie capilar por $\mathrm{mm}^{3}$, lo que indica neoformación capilar más allá del momento de culminación del desarrollo vascular en ratas normales.

\section{b) Efectos de la deprivación de estímulos en el desarrollo de la corteza visual}

La ausencia de experiencia visual produce modificaciones en varios componentes de la corteza visual, como las características electrofisiológicas neuronales, la densidad sináptica, la densidad de población neuronal que contiene VIP y somatostatina y la densidad de población glial. Estas variaciones aparecen siempre tras el periodo de máxima reorganización cortical mediada por la experiencia. Este periodo, que en la corteza visual de la rata se ha situado entre la tercera y la quinta semana de vida postnatal, se denomina periodo crítico. En las edades previas no se describen diferencias entre los distintos grupos experimentales.

Los métodos más comúnmente utilizados en el estudio de la vascularización cerebral han sido la inyección de sustancias tales como tinta china o resinas tales como MERCOX y otras. Las técnicas de inyección intravascular presentan algunos problemas para estudiar la microvascularización cerebral, mientras que resultan de gran utilidad en el estudio del resto de los segmentos de la vascularización cerebral.

Para el estudio de la microvascularización puede ser de gran utilidad el uso de técnicas histoquímicas utilizando enzimas presentes en la pared endotelial que forman parte de la barrera hematoencefálica. Con el uso de estas técnicas, podemos cumplir un doble objetivo, visualizar la red capilar y evaluar el estado funcional de la barrera. Una de las enzimas más comúnmente empleadas para el estudio morfofuncional de la microvascularización cerebral es la fosfatasa alcalina. Esta técnica histoquímica nos ofrece unos resultados brillantes en ciertas especies animales, sobre todo cuanto más alta sea su posición en la escala filogenética. Así, mientras se obtienen muy buenos resultados para gatos, perros o humanos, aparecen mayores problemas a la hora de llevarlo a la práctica en roedores, ya que el resultado carece de la necesaria limpieza y definición para hacerlo una herramienta de precisión en el estudio de la red microvascular.

A la hora de seleccionar un enzima que cumpliera los dos requisitos tanto de estar presente en la pared vascular y ser susceptible de manifestar mediante reacciones histoquímicas como de aparecer únicamente en el rango de la microvascularización encontramos un candidato idóneo en un enzima de la familia de las colinesterasas. Las colinesterasas se dividen en dos grandes grupos, las específicas (Acetil-Colinesterasas, cuya función en cerebro es degradar el neurotransmisor Acetil Colina) y las colinesterasas inespecíficas, (Butiril-, Propionil-Colinesterasa y otras). El papel primordial de la Acetil Colinesterasa se desempeña en las neuronas colinérgicas donde controla los niveles del neurotransmisor Acetil colina. La función y distribución de la Butiril Colinesterasa (BChE) permanece más oscura. Una de las localizaciones de la BChE es la pared endotelial de la rata, donde algunos autores han mencionado que participa en la inervación colinérgica de la red vascular. En su localización endotelial forma parte de la BHE enzimática. 
Aparte de la localización endotelial, la BChE se encuentra en neuronas de otras regiones del SNC donde su papel es objeto de discusión. Según algunos autores, la BChE se encontraría en neuronas que utilizaría un hipotético neurotransmisor sustrato del enzima BChE. Entre estas regiones se encontrarían aparte de varios núcleos talámicos, núcleos parasimpáticos como el vago, el ambiguo o el de Edinger-Westphal.

En el desarrollo postnatal de ratas criadas en oscuridad se ha descrito un significativo retraso en la maduración del patrón vascular a partir de la tercera semana de vida postnatal, que se refleja estudiando distintos parámetros morfométricos como la densidad vascular, que se incrementa notablemente desde el nacimiento hasta la tercera semana de vida postnatal, donde alcanza su valor máximo que prácticamente es el valor de la edad adulta. El comportamiento en ratas criadas en oscuridad es similar cualitativamente, con la salvedad de que los valores obtenidos en la edad adulta son significativamente menores a los valores obtenidos en animales control. La ausencia de experiencia visual es un factor que puede inducir una menor actividad sináptica, lo que implica menores requerimientos metabólicos, por lo que necesitan una trama vascular menor para hacer frente a la demanda.

Como hemos visto anteriormente, el desarrollo de la vascularización intracortical comienza con los vasos radiales que partiendo del sistema vascular leptomeníngeo, se internan en la profundidad de la corteza. La densidad de vasos penetrantes es máxima tras el nacimiento descendiendo progresivamente hasta la edad adulta como consecuencia del incremento del grosor cortical y del establecimiento de la red vascular. La principal característica de las observaciones llevadas a cabo sobre ratas criadas en oscuridad es que el descenso existente es mucho menos pronunciado que en animales control, existiendo entre las dos situaciones diferencias estadísticamente significativas, por lo que podemos establecer que existe un retraso en la maduración del patrón vascular como consecuencia de la ausencia de experiencia visual.

La determinación de la superficie vascular por unidad de superficie cortical nos muestra como al igual que la densidad vascular, la superficie vascular total es igualmente menor en ausencia de experiencia. Similares resultados pero en dirección opuesta aparecen en estudios sobre la experiencia compleja, es decir, en ratas criadas en entornos complejos se aprecia un aumento de este parámetro respecto a ratas control.

Los cambios producidos por la experiencia sobre la densidad neuronal es uno de los aspectos más profusamente estudiados tanto en incrementos de la experiencia como en deprivación de la misma. Pese a ello, consideramos necesario establecer los valores en nuestro material para poder calcular las relaciones con el resto de los parámetros medidos.

El principal resultado obtenido es que la diferencia entre los dos grupos experimentales se incrementa progresivamente tras la segunda semana de vida alcanzando su valor máximo en los animales adultos siendo inferior en ausencia de experiencia mientras que en animales criados en entornos complejos se aprecia un descenso de la densidad neuronal consecuente al incremento del neuropilo. 
En el desarrollo postnatal de la corteza se produce la muerte programada de las células no funcionantes, por lo que en ausencia de experiencia podemos pensar que la densidad neuronal es menor. En cambio, aumentos de la experiencia visual no conllevan un aumento de la división neuronal, por lo que el incremento del neuropilo supone una disminución relativa de la densidad neuronal.

Aparte de demostrar la menor densidad neuronal, vascular (y astroglial) existente en ausencia de experiencia visual, es interesante relacionar los valores neuronales y vasculares encontrados en una misma sección de tejido. El estudio del número de vasos por neurona nos muestra cómo este parámetro permanece constante en ambas situaciones, al igual que la relación de superficie vascular por neurona.

\section{Conclusiones}

La experiencia visual induce cambios en el córtex estriado que se traducen en un incremento de los requerimientos metabólicos y estos se manifiesta en un aumento de la densidad vascular.

Mientras que el desarrollo postnatal en entornos visuales enriquecidos cursa con un incremento en la arborización y densidad vascular, la ausencia de experiencia visual origina un descenso en la actividad cortical que induce un descenso en la densidad neuronal y vascular así como un retraso en la maduración del patrón angioarquitectónico cortical. La relación entre la población neuronal y las densidades vascular y astroglial y la superficie vascular no se modifica. Estas alteraciones se restringen a la corteza visual y aparecen pasado el «periodo crítico». 


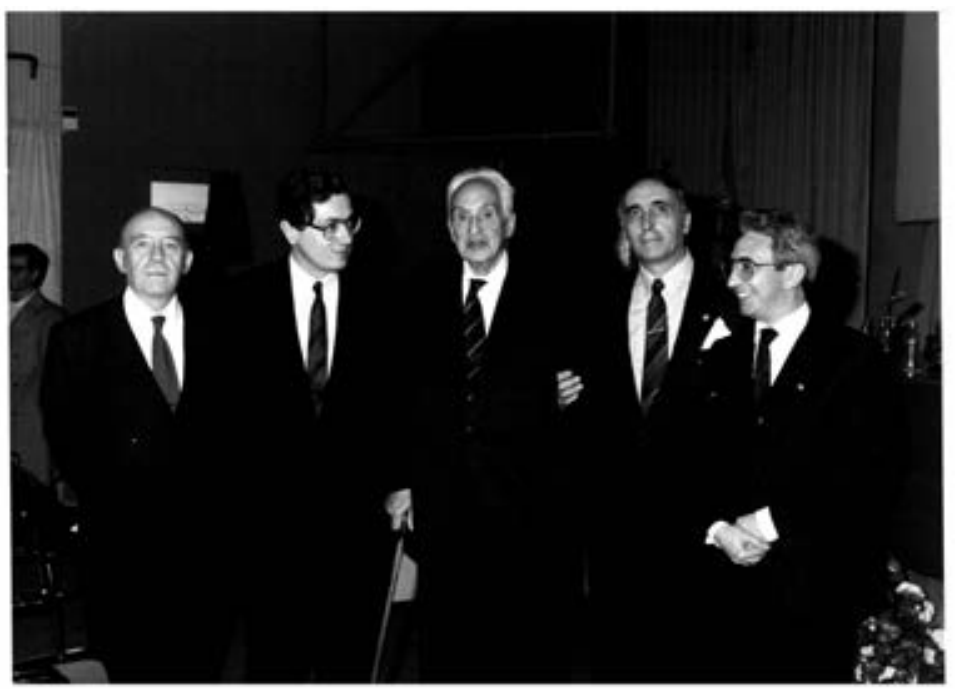




\section{PSICODIDÁCTICA Y NEURODIDÁCTICA: DOS DESCONOCIDAS DE LOS DOCENTES MÉDICOS}

Jesús FERNANDO ESCANERO

Catedrático de Fisiología. Departamento de Farmacología y Fisiología

Facultad de Medicina. Universidad de Zaragoza

El establecimiento de relaciones entre los conocimientos de diferentes ciencias constituye una tendencia predominante en la actualidad, debido a que este tratamiento proporciona resultados científicos que propician un conocimiento más íntegro y complejo de la realidad. Tal es el caso de la Didáctica y la Psicología (Psicodidáctica) y la Didáctica y las Neurociencias (Neurodidáctica o Neurodocencia). Ambas materias satisfacen una necesidad, en lo que a investigaciones pedagógicas se refiere, para penetrar en la esencia del proceso educativo por todas sus aristas. Los imperativos del desarrollo social han provocado la obsolescencia de los enfoques tradicionalistas y parcializados de las ciencias pedagógicas que se restringían a desarrollar investigaciones dentro de los esquemas rígidos de cada disciplina, los cuales fueron útiles en su momento histórico porque fue necesario primero profundizar en los contenidos parciales como paso previo para estudiar la totalidad.

\section{Interdisciplinariedad ${ }^{1}$}

La interdisciplinariedad es el establecimiento de nexos recíprocos, interacciones, intercambios múltiples y cooperación entre ciencias particulares que tienen un objeto de estudio común, lo que permite estudiarlo con distintos modelos teóricos y metodológicos (herramientas) para desentrañar los diversos aspectos de su esencia, con el propósito de lograr un conocimiento cada vez más integral del mismo y de las leyes que rigen su existencia y desarrollo.

1 El término interdisciplinariedad surge por primera vez en 1937 y le atribuyen su invención al psicólogo Louis Wirtz. 
Para abordar cualquier consideración de carácter interdisciplinario, primero, se debe partir de la disciplinariedad. Una disciplina puede definirse como una categoría organizadora del conocimiento científico con su autonomía, fronteras delimitadas, lenguaje propio, técnicas y teorías específicas. Las disciplinas se instituyen en el siglo XIX con la aparición de las universidades modernas y se desarrollan con el auge de las investigaciones científicas durante el siglo Xx. La disciplinariedad es, en consecuencia, la organización de la ciencia en diversas disciplinas.

Desde un enfoque histórico, la disciplinariedad ${ }^{2}$ constituye un resultado de la fecundidad del desarrollo científico, ya que delimita un dominio de competencia sin el cual el conocimiento se volvería fluido y vago. El concepto de disciplina presupone un objeto de estudio científico plenamente identificado y propio, en su objetividad y homogeneidad. Pero con la evolución social y, por tanto, científica, el enfoque disciplinario que constituyó un resultado valioso del y para el avance de las ciencias, se fue convirtiendo en una rémora por el riesgo cada vez más creciente de hiperespecialización del investigador y cosificación del objeto, concebido como cosa en sí, desvinculado de la realidad (de la cual es abstraído) y de sus relaciones con otros objetos, con los cuales está indisolublemente relacionado.

Los límites disciplinarios, tan necesarios en el surgimiento y desarrollo de las ciencias en su evolución, terminaron aislando las disciplinas unas de otras y, por tanto, ofreciendo una visión fragmentada y parcelada de la realidad. Si la historia oficial anterior de la ciencia es la disciplinariedad, en estos momentos la interdisciplinariedad constituye su continuidad lógica. Por tanto, el desarrollo de la ciencia no solo ha sido disciplinar, sino interdisciplinar también, de lo contrario no hubiera tenido lugar el avance logrado hasta el presente.

En la actualidad, se habla no solo de interdisciplinariedad, sino también de transdisciplinariedad, multidisciplinariedad, pluridisciplinariedad y polidisciplinariedad y aunque los autores en muchos casos ofrecen definiciones diferenciadoras entre estos términos, en realidad son matices del mismo fenómeno que refleja la necesidad de una concepción más compleja e integradora de la ciencia.

\section{Psicodidáctica}

Titone comienza su libro de este título con la siguiente expresión: «el término Psicodidáctica está siendo utilizado con especial frecuencia por el autor desde finales de los años cincuenta, pero su historia conceptual es mucho más remota». En el primer capítulo plantea dos definiciones de distinta amplitud:

2 En el origen, la palabra disciplina designaba un pequeño fuste que servía para autoflagelarse, permitiendo, por lo tanto, la autocrítica; en un sentido degradado la disciplina deviene en un medio de flagelación a los que se aventuran en el dominio de las ideas que el especialista considera como de su propiedad (4). 
La primera, restringida, incluiría los estudios psicológicos relacionados con los problemas más generales de la metodología didáctica, es decir, el proceso de comunicación didáctica, las modalidades de interacción profesor-alumno, las características y los factores de los aprendizajes, etc. La definición amplia incluiría también el campo multiforme de la psicología de las disciplinas de estudio, o más concretamente, de las distintas posibles actividades formativas que pueden ponerse en práctica en el ámbito escolar.

La Psicodidáctica concibe el proceso de enseñanza-aprendizaje como un fenómeno dialéctico, contradictorio, cuya solución promueve el desarrollo de la personalidad de profesores y alumnos. Estas contradicciones ocurren primero a nivel interpsicológico, es decir, entre los sujetos participantes y, después, a nivel intrapsicológico, dentro de la propia subjetividad de los mismos. En el caso de los profesores es el proceso de profesionalización docente quien debe encauzar y agudizar dichas contradicciones para promover su desarrollo profesional y, en el caso de los alumnos, el carácter dirigido del proceso de enseñanza-aprendizaje por parte de los profesores es quien debe provocar este desarrollo.

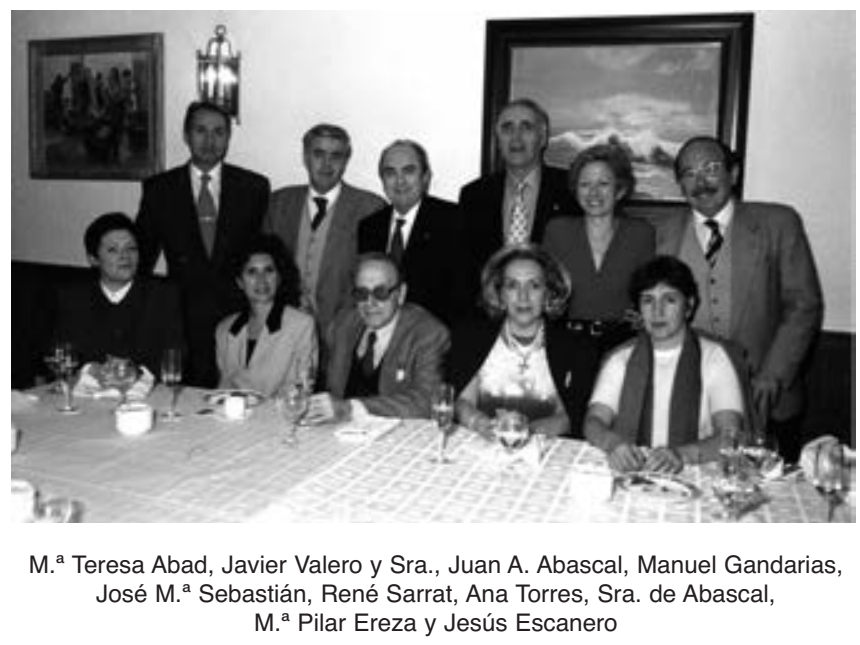

\section{Neurodidáctica}

En 1988, Gerhard Preiss, catedrático de Didáctica de la Universidad de Friburgo, propuso introducir una asignatura autónoma basada en la investigación cerebral y en la Pedagogía, a la que denominó Neurodidáctica o Neurodocencia. Concedía una importancia decisiva al hecho de que el aprendizaje se basa en procesos cerebrales y de que los resultados cognitivos se amplían paralelamente al desarrollo del cerebro infantil. Sobre estos hechos, la Neurodidáctica investiga las condiciones bajo las que el aprendizaje humano puede optimizarse al máximo. 
Frente a la Psicodidáctica, esta disciplina se encuentra en plena construcción. En la actualidad, las relaciones en las zonas de intersección entre las dos ciencias que la integran se hallan en sus comienzos.

Para aproximarnos a lo que esta materia puede representar en el futuro, a continuación, se exponen algunas de las áreas en las que actualmente se concentran diferentes esfuerzos. Así, en estos momentos, en el área de los trastornos específicos del aprendizaje se están desarrollando investigaciones muy prometedoras en los campos de, por ejemplo, la discalculia (dismatemáticas), dislexia, disgrafía, trastornos específicos del desarrollo del lenguaje (TEDL), etc. Para poner de manifiesto la importancia de estos hechos baste mencionar que la dislexia, una deficiencia en la lectura y escritura afecta a un $5 \%$ de los niños entre 7 y 9 años, especialmente a varones; en la actualidad, la dislexia está siendo tratada usando nuestro conocimiento de los procesos cerebrales para descodificar fonemas, sílabas y palabras. Otro caso, con el que descubriremos un nuevo horizonte, lo constituye el Síndrome de Deficiencia Atencional con Hiperkinesia (SDAH); se trata del trastorno de la conducta de la niñez diagnosticado más comúnmente, estimándose entre un 3-5\% la prevalencia en los niños en edad escolar, y aunque es más frecuente en los niños que en las niñas, estas lo presentan con mayor intensidad (6). Su tratamiento se hace con metilfenidato. En USA, se ha descrito que, en las escuelas de algunos distritos, la proporción de niños tomando este fármaco excede las más altas estimaciones de la prevalencia del SDAH, lo que significa que más gente de la que lo necesita está siendo tratada farmacológicamente. Ello nos lleva a otro interesante dominio de la Neurodidáctica: la utilización de medios farmacológicos para mejorar la función normal neurocognitiva.

La prescripción de estimulantes tales como metilfenidato y dextroanfetaminas, como ayudas para el estudio en estudiantes de la high school y el college, se estima en un $16 \%$ en algunos campos. Otro dato, las ventas de suplementos nutricionales que prometen mejorar la memoria en las edades medias de la vida y etapas posteriores han alcanzado, solo en Estados Unidos, un billón de dólares anualmente. Tal desembolso es totalmente explicable, por la edad a la que se produce su pérdida, tercera década de la vida en adelante, y por lo importante y preocupante y/o molesto que puede resultar a partir de la cuarta, para las personas sanas. Estas pérdidas de la memoria no tienen por qué ser el anuncio de una futura demencia, sino parte del patrón normal del envejecimiento cognitivo. Consecuentemente, los cambios que subyacen al normal declinar de la memoria difieren probablemente de aquellos que subyacen a la enfermedad de Alzheimer, indicando que el tratamiento también debe diferir. Si bien el donepezil, un inhibidor de la colinesterasa que se utiliza para tratar la enfermedad de Alzheimer, mejoró la capacidad de trabajo en un estudio de pilotos sanos en edades medias de la vida en un entrenamiento de vuelos simulados, las compañías farmacológicas no cejan de buscar fármacos que mejoren la memoria en individuos normales. Los fármacos hasta ahora conocidos pueden incluirse en uno de los dos grupos siguientes: 
- Los que apuntan a la inducción inicial de potenciación a largo plazo y

— Los que se centran en los últimos estadios de la consolidación de la memoria.

Los que se incluyen en la primera categoría son fármacos que modulan los receptores del AMPA (alfa-amino-3-hidroxi-5-metil-4-isoxazol ácido propiónico) para facilitar la despolarización incluyendo entre ellas las «Cortex Pharmaceuticals' Ampakines». Los de la segunda, son fármacos que aumentan la CREB (la CAMP response element-binding protein), una molécula que a su vez activa genes para producir proteínas que refuerzan la sinapsis. Uno de estos fármacos es la molécula MEM14.

En otro sentido, también se están ensayando fármacos para evitar las alteraciones provocadas por estrés post-traumático.

Otros casos, como los implantes cocleares, que han cambiado la vida de centenares de niños sordos, el transplante celular y la neurocirugía, en un sentido más amplio, utilizada especialmente para el tratamiento de enfermedades mentales están en un auge inusitado; los niños hemisferectomizados han permitido estudiar las vías de aprendizaje con la mitad cerebral. Por continuar en el campo de la infancia, la atención al bilingüismo y a los niños superdotados forman parte de esta fascinante materia.

En pacientes seniles que pueden reactivar su corteza prefrontal tras el entrenamiento con simples computadoras... Técnicas no invasivas como la estimulación magnética transcraneal (TMS) de áreas cerebrales diana son la base de nuevos tratamientos prometedores para la depresión y otras psicopatologías.

Para concluir permítasenos una pequeña disquisición del rol de esta materia en el ciclo del aprendizaje.

\section{Ciclo del aprendizaje}

Kolb con el ciclo de aprendizaje en cuatro etapas, como ha hecho una gran cantidad de autores, realizó una descripción muy próxima a cómo trabaja el cerebro. Para este autor, el ciclo del aprendizaje se origina de una experiencia concreta («aprendizaje experiencial»). La experiencia es solo el inicio y requiere reflexión (observación reflexiva), la creación de nuevas ideas de ese significado (desarrollo de abstracciones) y experimentación activa, actuando sobre esas nuevas.

El propio Kolb indica que el ciclo de aprendizaje surge de la estructura cerebral. La experiencia concreta proviene de la corteza cerebral (sensorial y postsensorial), la observación reflexiva incluye la parte posterior de la corteza integrativa temporal, la creación de nuevas hipótesis abstractas ocurre en la corteza integrativa frontal y la experimentación activa involucra a la corteza premotora y motora.

Dos hechos clave derivados del conocimiento de las redes neuronales nos conducen a la mejora del aprendizaje. 
En el cerebro del ser humano se estima que existen, al nacer, del orden de los cien mil millones de células nerviosas y más de cien billones el número de conexiones sinápticas entre las células para formar redes locales. Al comienzo de la vida estas conexiones están uniformemente distribuidas pero procesos de aprendizaje que conllevan sensaciones o acciones asociadas refuerzan las sinapsis que se activan durante el proceso y las mantienen a largo plazo. El aprendizaje modela el cerebro: las conexiones poco utilizadas desaparecen y, contrariamente, se refuerzan y consolidan las más activas. Esto quiere decir que, si el proceso de percepción se repite con frecuencia, las conexiones cerebrales involucradas se estabilizan de tal forma que su estimulación asociada corresponde a una misma experiencia que se añade al acervo cognitivo del sujeto.

El segundo hecho lo constituyen las emociones. Estas constituyen un papel decisivo en la formación de la memoria. El responsable es el sistema límbico. Este sistema posibilita una amplia gama de estados emocionales: rabia, tristeza, disgusto, felicidad y placer. Cada señal que llega a los tejidos se dirige a él, en paralelo a la vía que lleva a la corteza cerebral. Las impresiones a las que el sistema límbico ha impuesto un sello emocional se graban profunda y perdurablemente en la memoria.

\section{Conclusión}

Como educadores, la conclusión, siquiera muy general, es clara: en el proceso de aprendizaje se ponen en juego «cabeza, corazón y manos», como decía Pestalozzi. Es necesario aunar las facultades de pensar, sentir y actuar para la realización de un aprendizaje significativo. Y de los fundamentos del «aprender/cabeza/pensar» se ocupa esta materia. 


\section{AL PROFESOR RENÉ SARRAT: UNA VISIÓN DESDE OTRA ESCUELA}

JOSÉ LUIS NiETO AMADA

Profesor Titular de Anatomía Humana. Director del Departamento de Anatomía e Histología Humanas

Facultad de Medicina de Zaragoza

En octubre de 1960 iniciaba en la antigua Facultad de Medicina de Zaragoza mis estudios de Medicina. Procedía de la Facultad de Ciencias, ubicada en una de las alas del mismo edificio de la plaza de Basilio Paraíso, donde había cursado, con escasa vocación matemática, el temido curso selectivo que abría las puertas a las carreras técnicas y científicas. Un traslado bastante radical, compartido también por otros compañeros de Colegio y que, en mi caso, contó con el acertado consejo del catedrático de Biología, don Cruz Rodríguez, quien acertó a vislumbrar en mí mayor facilidad para los conocimientos biológicos que para los científicos.

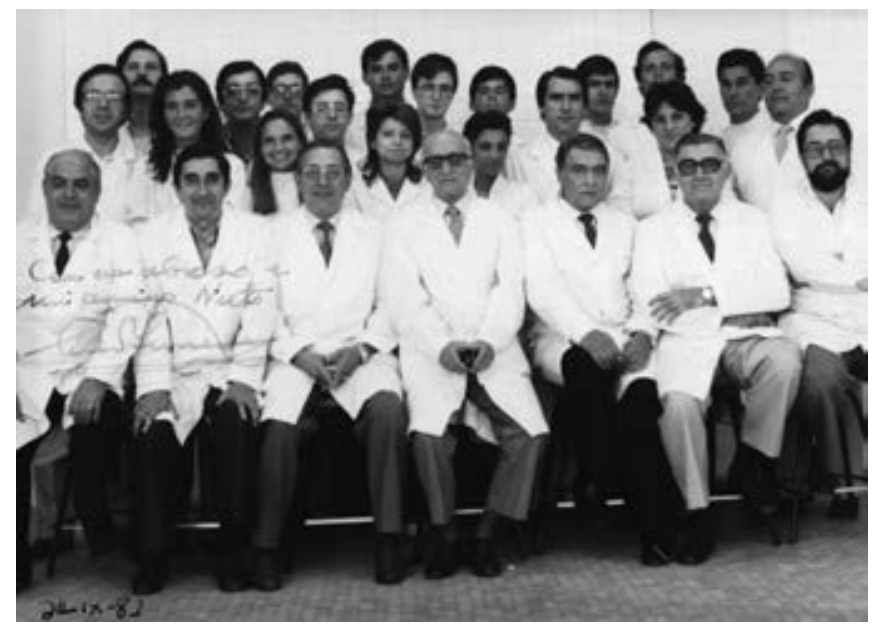

Profesores y alumnos de la cátedra del Profesor D. Luis Jiménez. Primera fila: F. Mardones, J. L. Nieto, S. Pellejero, D. L. Jiménez, P. Asirón, J. M. Gómez Beltrán, J. A. Tierz.

Detrás, entre otros: B. Ebri, A. Monzón, L. Jiménez-Salillas, J. Whyte, J. A. Ramos, J. Blasco, M. Tajada, R. Soravilla 
Con este bagaje llegaba, ese mismo año, a la cátedra de Anatomía Humana del doctor don Luis Jiménez. Como otros cursos, don Luis solicitaba alumnos internos que ayudásemos en los laboratorios de Embriología y Cromatografía de su cátedra y tras el preceptivo examen fuimos elegidos Mirentxu Oyarzábal y yo. En este camino, no tardé en conocer a René Sarrat, alumno interno pensionado, por aquel entonces, de la cátedra de Anatomía de don José Escolar.

No faltaban en aquellos años los comentarios sobre las posibles discrepancias personales entre ambos catedráticos de Anatomía. Tampoco es aquí lugar para analizarlos. Lo cierto es que, al margen de estas diferencias, existía una buena camaradería entre todos los profesores y estudiantes internos de ambas cátedras. Un afecto casi clandestino para no herir, por si acaso, la idiosincrasia de ambos jefes. En la cátedra a la que llegaba encontré a los doctores Enrique Pelegrín, Ramón Azcona, Santiago Pellejero, Pedro Asirón y Paco Burgos. En la otra, recuerdo a Pedro Amat, Víctor y José María Smith, Elvira Farrés, Inés Fernández y Vicente Calatayud, por no citar nada más que aquellos con los he seguido manteniendo la amistad.

Más numerosos éramos los estudiantes internos de una y otra cátedra. Además de René, allí estaban Saldaña, Pedro Mestres, Javier Pisón, Santiago Rodríguez, Calcedo y Fernando Mardones, además de los dos citados que acabábamos de incorporarnos. Aquí mis recuerdos son mucho más extensos, sobre todo si añado al grupo a los irrepetibles bedeles Mariano e Ignacio Oquendo, sin los cuales no entenderíamos las muchas horas pasadas en la sala de disección.

En este ambiente tan especial de nuestras tardes universitarias, donde al margen de clases y prácticas trabajábamos con enorme seriedad y dedicación, no tardé en congeniar con René. Como disector experto que era, solía pasar a nuestro tanatorio para preparar los cadáveres que iban destinados a la cátedra de Escolar. Tampoco faltaban otras

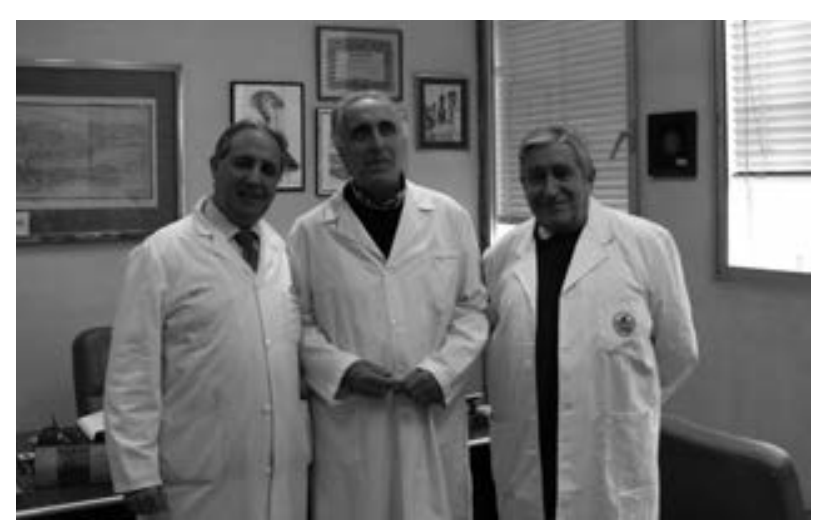

J. Obón, René, J. L. Nieto 


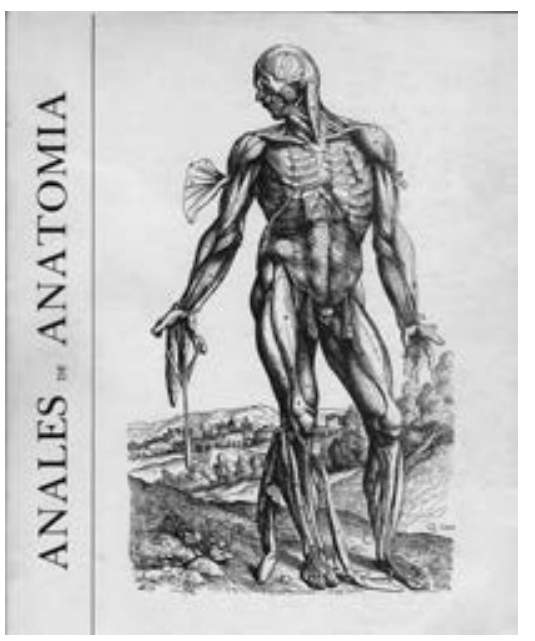

Anales de Anatomía. 2. ${ }^{a}$ época

Director R. Sarrat; secretario redacción J. L. Nieto

visitas, casi clandestinas, para extraer los cerebros de algunos fallecidos antes de ser enterrados, labor que René dominaba como pocos y a la que solíamos asistir algunos internos de ambas cátedras Lo que no llegamos nunca a compartir, fueron esas meriendas improvisadas que, en ausencia del respectivo patrón, organizábamos después de una de esas tardes de trabajo dedicadas a preparar las piezas cadavéricas.

Enseguida abandonó René la cátedra de don José Escolar. Primero temporalmente, para especializarse en la neurosecreción hipofisaria, en el departamento del profesor Bargmann; luego, de manera definitiva para hacerse cargo de la cátedra de Anatomía de Bilbao. Aún seguimos viéndonos de tiempo en tiempo. Recuerdo de manera especial la elogiosa presentación que hizo de mi persona en una de mis intervenciones en la Academia de Ciencias Médicas de Bilbao, allá por el invierno de 1975. Por primera vez, en ese acto, supe algo que parecía inevitable desde sus tiempos de Zaragoza y era su matrimonio con Ana Torres, una de las colaboradoras más jóvenes y perseguidas del laboratorio de don José Escolar, una estancia siempre espiada desde nuestros vecinos laboratorios.

Con el tiempo René volvió a Zaragoza, ahora para ocupar la cátedra vacante de mi maestro don Luis Jiménez. Trabajamos juntos para unificar y mejorar la docencia anatómica de dos escuelas morfológicas tan diferentes como las de Escolar y Jiménez. Y, sobre todo, rescatamos del olvido a la revista Anales de Anatomía, la publicación que don José Escolar había fundado en la Universidad de Granada, a la que logramos llevar hasta el número 100. Un esfuerzo sin la ayuda económica de quieres parecían obligados a darla, pero que hicimos llegar, sin coste alguno, a todos los miembros de la Sociedad Anatómica Española y a las bibliotecas más importantes de Europa y Estados Unidos. Un logro no valorado y cuya pérdida aún no ha sido comprendida por la Universidad de Zaragoza. 
Algo que no viene al caso enfrió estas relaciones tan fructíferas. Pero, como no podía ser de otra manera, seguimos nuestra colaboración docente e investigadora, ahora yo más inclinado a establecer, de una vez por todas, una antropología para la población aragonesa, mientras René derivaba sus inquietudes hacia la anatomía del oído y a la histología de arterias en relación con la aterosclerosis. Pero aunque inmersos en campos tan dispersos, no faltó cada año mi participación en el curso de Anatomía artística, una asignatura del doctorado que René implantó y dirigió desde su arribo a Zaragoza.

Muchas cosas podía añadir de René, pero solo repetiría lo que sus compañeros de la escuela anatómica de Escolar van a dejar escritas en este libro. Diré, sin embargo, algo que pocos conocen y es que René se inició en la Anatomía humana de la mano de don José Conde Andreu, uno de los catedráticos más cultos y peculiares que ha tenido nuestra Facultad de Medicina. Por eso, supongo que René conoce de primera mano la vehemencia de Conde por desentrañar los mecanismos anatómicos que llevaron a Cristo a morir en la cruz y, también, aquí no me cabe dudarlo, la admiración de Conde por las pinturas anatómicas que Santiago Ramón y Cajal dejó en esta Facultad. Cuenta René, que cuando don José Conde, a mitad de una clase, precisaba una representación anatómica invitaba amablemente al interno René Sarrat a buscar a su cátedra el monumental atlas de Cajal. Entre tanto, don José Conde aprovechaba para pasar lista a la clase y cuando el interno llegaba, agotado con el encargo (el atlas mide más de un metro de altura y sobrepasa los quince kilos de peso), don José ya le había endosado la falta correspondiente y desde luego inamovible, pues como acertadamente razonaba el catedrático aunque «era cierto que había venido a clase, también lo era que no estaba allí cuando se pasó la lista». Sin embargo, poco antes de morir don José Conde demostraba su aprecio a René, dejándole por escrito en su testamento la cartera de mano con la que él acudía cada día a dar la clase.

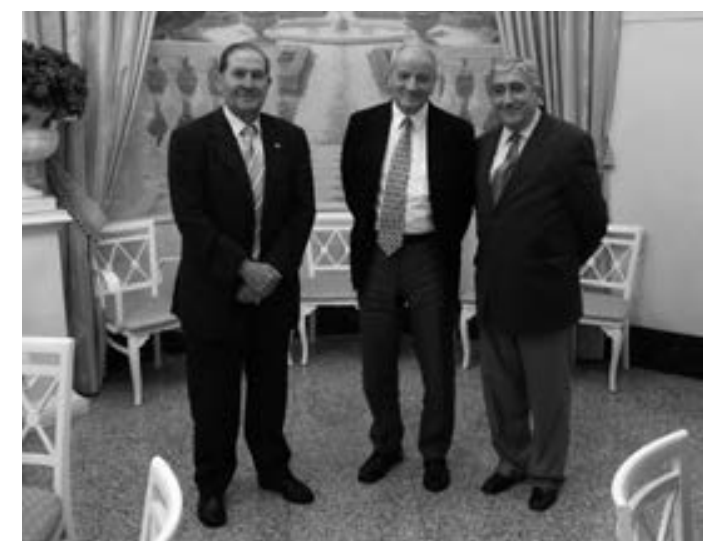

XV Congreso Internacional de la Sociedad Española de Antropología Física.

F. Solsona (Presidente Real Academia de Medicina),

G. Larruy (Ex rector Universidad de Toulouse)

y J. L. Nieto (Presidente del Congreso) 
En su jubilación, René ha querido marcharse huyendo de los acostumbrados homenajes. Incluso ignora la existencia de este Amicorum liber que le brindamos todos sus amigos y que será nuestra sorpresa. En esta Facultad zaragozana, René se ha formado, ha sido profesor, vicedecano y durante años director del Departamento de Anatomía e Histología y en ella quedan una parte importante de sus discípulos, yo diría que los últimos pero también los más entrañables, aquellos que con tanto cariño y dedicación han arropado las ultimas lecciones que ha dado en esta Facultad de Medicina. Unas lecciones que serán recordadas en Zaragoza, como antes lo han sido en Bilbao y Las Palmas de Gran Canaria, por quienes, siendo sus compañeros o sus alumnos, hemos tenido el privilegio de escucharlas alguna vez. Por todo ello y como actual Director de este Departamento de Anatomía e Histología Humanas solo me queda decirte que aquí, en estos laboratorios y despachos, tendrás siempre tu casa. Un abrazo. 


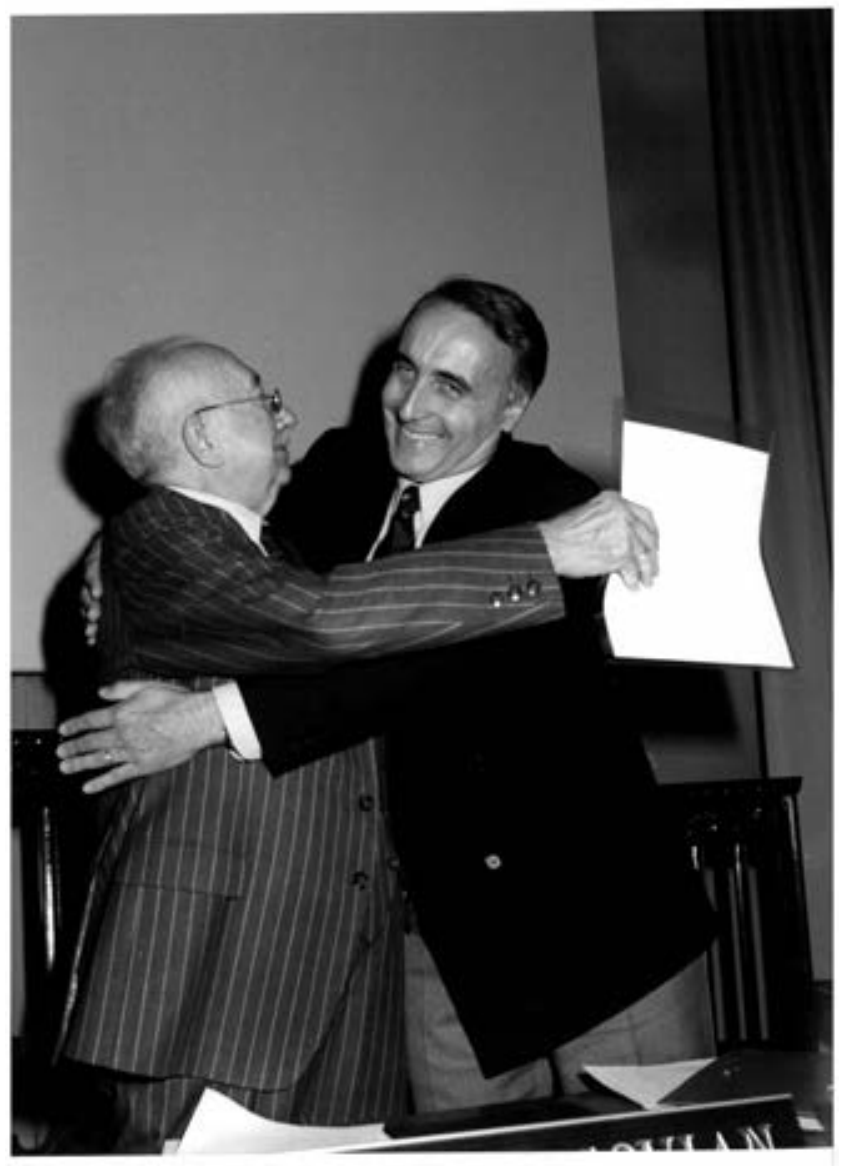




\section{GRACIAS, PROFESOR SARRAT}

JUAN ANTONIO VECINO

Profesor Asociado. Departamento Anatomía e Histología Humanas

Facultad de Medicina de la Universidad de Zaragoza

Director del Máster de Acupuntura

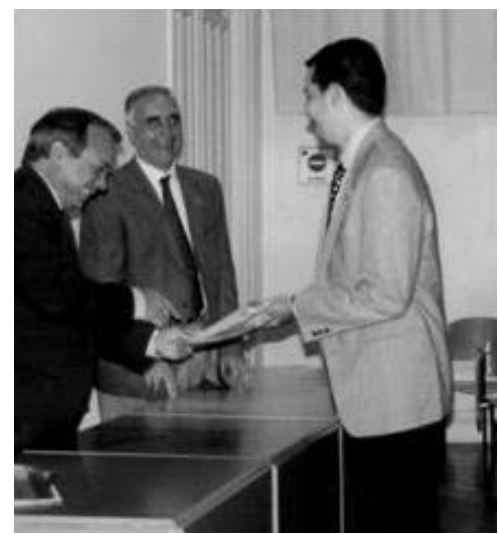

Entrega de diploma del Máster de Acupuntura

...y entonces fue cuando pensé que había llegado el momento de que la Acupuntura se introdujera en la Universidad.

Como primera medida me acerqué a la hemeroteca y biblioteca de la Facultad para comprobar qué documentación existía ya en ella sobre el tema de la acupuntura.

Cuál fue mi sorpresa, cuando hallé una tesis sobre el estudio anatómico de los puntos de acupuntura, realizada en la Universidad de Las Palmas pero dirigida por el profesor Sarrat, catedrático de Anatomía de la Facultad. No podía haber sido mejor mi suerte, todo un catedrático de la Facultad de Medicina de Zaragoza se había interesado por la Acupuntura.

Me dirigí al departamento, para solicitar una cita con él.

Al momento de llegar, me atendió. Yo le expliqué que, desde hacía varios años, practicaba acupuntura, incluso había realizado mis estudios en China, y que aún estando tremendamente satisfecho con los resultados obtenidos con esta técnica, mi condición de médico, es decir científico, me exigía investigar sobre cuáles eran sus mecanismos de acción, para de esa manera eliminar ese «halo» que de empírico presentaba.

Desde ese mismo momento, me acogió bajo su protección. Me apoyó con el mismo entusiasmo que si el proyecto fuera propio. Confió en mí y siempre defendió la causa en cualquier foro que se lo pidiera, y solo me exigía algo a cambio, hacer las cosas bien y con seriedad. 
De esa connivencia nacieron los primeros cursos de acupuntura que se impartían en la Facultad de Medicina de Zaragoza. Cursos que, gracias a su apoyo y lucha en el Rectorado, terminaron por convertirse en 1998 en Título Propio «Máster de Acupuntura». En la actualidad, ya se está realizando la 9. ${ }^{a}$ edición y ha contado con cerca de doscientos participantes.

No conforme con esto, apoyó desde un principio la implantación de una asignatura de acupuntura en los estudios de esta Facultad. Inicialmente de «libre elección», para pasar en la actualidad a convertirse en una asignatura optativa de la licenciatura de Medicina. Trescientos nuevos médicos, conocen qué es y qué puede aportar la acupuntura a nuestra profesión, sin sorprenderse, escandalizarse o desdeñar su uso.

Estuvo siempre en la retaguardia ante cualquier requerimiento que se le hiciera para apoyar nuevas iniciativas. Por ejemplo, el concierto de la Universidad de Zaragoza con la Universidad de Medicina Tradicional China de Pekín.

\begin{abstract}
USING ACUPUNCTURE TO TREAT BONE FRACTURES
Authors: René Sarratc; José Ignacio Bonafonteac; Juan Antonio Vecino Ferrerb. Jaime Whytec ; Azucena Gálveza ; Ana Whytea ; $\mathbb{M}^{2}$ José Martinez-Sañudoa ; J Maria Peiróe ; Alberto Labodiaa ; Joaquin Sopenad

aunisad de Cirugia del Departamento de Patologia Animal (Servicio de Acupun Veterinaria) de la Facultad de Veterinaria. Universidad de Zaragoza. SPAIN.

bJefe de la Unidad de Dolor - Senvicio de Acupuntura. Cruz Roja (Zaragoza). SPAIN. cDepartamento de Ciencias Morfológicas. Facultad de Medicina (Zaragoza). SPANN. dDepartamento de Medicina y Cirugía Animal de la Facultad de Ciencias Experiment: y de la Salud de la Universidad Cardenal Herrera. C.E.U. Valencia. SPAIN.

eDepartamento de Productión Animal y Ciencia de los Alimentos. de la Facutad Veterinaria. Universidad de Zaragoza. SPAIN.

\section{ABSTRACT}

A study was designed to measure the effect of acupuncture and electroacupunture bone ossification after a fracture. An experimental ostectomy (diameter $2 \mathrm{~mm}$ ) i performed on two groups of rabbits at the level of the diaphysis of the femur bone. ( group $(n=24)$ recerved acupuncture and low frequency electrical stimulation. The sec group (control, $n=12$ ) did not receive any treatment after the fracture (spontaneous b consolidation). There were differences befween groups regarding bone structure blood biochemistry, specifically the plasma concentrations of calcium and phosphor ions. The distribution of osteoblasts and the sppearance of bone trabeculae were $m$ compact in animats that recewed acupuncture. The plasmatic concentrations of calc and phosphorous were maintained at 2:1 (the most adequate for bone synthesis) in treatment group starting day 1 (maximum 5 days), butmuch later in the control group.
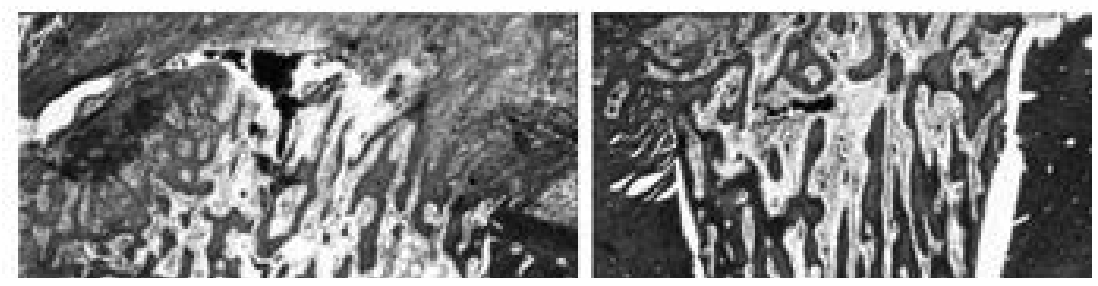
Siempre ha acudido a los actos de inauguración o clausura de las diferentes ediciones del Máster como si del acto académico más importante se tratara. Solo su presencia ha dignificado al máximo todos los actos a los que asistía.

Su gran carisma, su gran simpatía, amabilidad, no son nada comparados, con el grandísimo respeto y admiración que su condición de intelectual, y no solo en el ámbito médico, le profesamos todos aquellos que le conocemos. Esto ha hecho más fácil que el desarrollo de la Acupuntura en esta Universidad, y por qué no decirlo, en toda España, haya avanzado en los últimos diez años, más que en toda su historia en nuestro país, que ya tiene una antigüedad de 100 años. Su opinión sobre la acupuntura, hace meditar y da confianza en ella a todos los compañeros que le escuchan.

Qué gran alegría fue conseguir el primer proyecto de investigación apoyado por el CONSI+D que se daba en España para temas de acupuntura. Ese trabajo en colaboración con el Departamento de Patología Animal (Servicio de Cirugía) de la Facultad de Veterinaria de Zaragoza, demuestra que la acupuntura interviene en los procesos del metabolismo del hueso. Gracias a ello, se nos abrieron las puertas de otras universidades, españolas y del resto del mundo. Hoy ese trabajo ha sido presentado en el NIH (Bethesda-EE.UU.) uno de los centros de investigación médica más importantes del mundo.

En la actualidad, la Facultad de Medicina de Zaragoza es un referente mundial sobre acupuntura y eso siempre tendremos que agradecérselo al profesor Sarrat.

Pero si un día, finalmente, la acupuntura ocupa el lugar que los acupuntores deseamos, todos, no solo en Zaragoza, no solo en España, sino en el mundo entero, tendremos que agradecer todo el apoyo y facilidades que, desinteresadamente, y solo seguido por su curiosidad científica, nos ha dado el profesor Sarrat.

Sin duda alguna, debe encabezar el listado de los que más han ayudado a la acupuntura para que esta ocupe su lugar, dentro del conjunto de la medicina. Y todo ello sin haber sido acupuntor.

Gracias profesor, muchas gracias, porque, sin su apoyo, nada de lo que hoy es una grandísima ilusión, alegría y esperanza para todos los médicos acupuntores, sería realidad. 


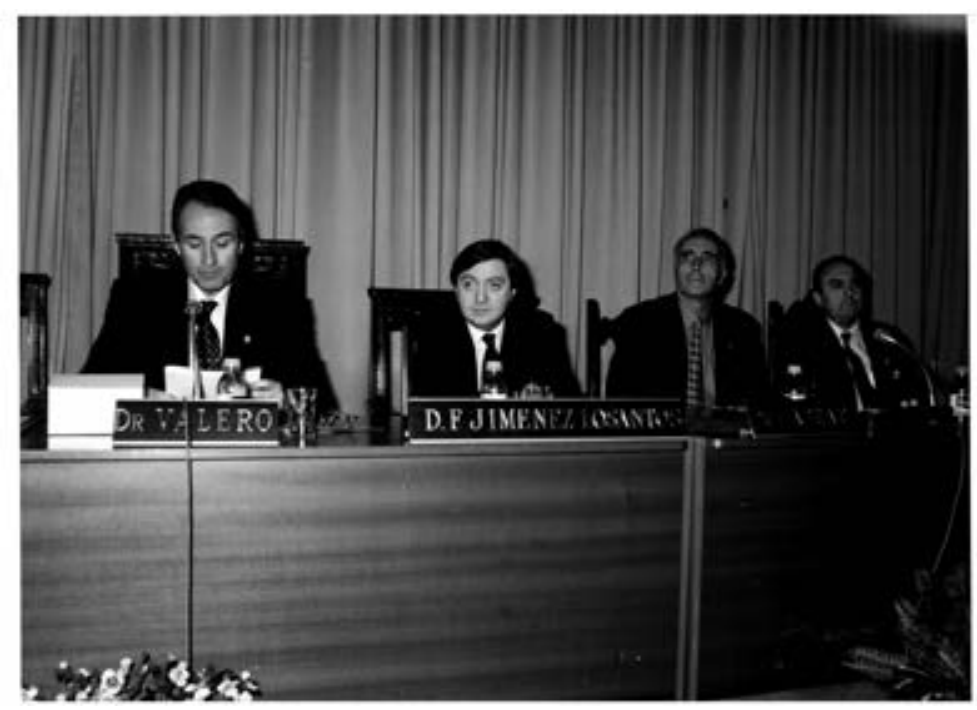




\section{PINCELADAS SOBRE ODONTOLOGÍA}

Jesús Ángel ObÓn Nogués

Médico-Odontólogo. Profesor Asociado de Anatomía y Embriología Humanas

Facultad de Medicina. Universidad de Zaragoza

Antes de dar unas pinceladas sobre la Odontología y la importancia que los dientes tienen en el estudio de las comunidades humanas, permítame la confianza de dirigirme a usted con todo el afecto que le tengo, desde hace dos años que tuve la suerte de conocerle, para desearle que su jubilación, ese merecido descanso después de tantos años en las aulas, se convierta en una etapa de sosiego, de mayor libertad para dedicarse a personas o a actividades que el trabajo cotidiano le impidió realizar con la intensidad deseada.

Espero y deseo de todo corazón que esta nueva etapa de su vida sea de júbilo, alegría y regocijo.

Los dientes son uno de los registros más abundantes y fiables para el estudio de las comunidades humanas, tanto actuales como primitivas, por ello son muy importantes los Sistemas de Nomenclatura Dental ya que aluden a un diente determinado con rapidez y precisión. En dependencia de la Nomenclatura utilizada, existe un número o un símbolo específico para cada diente, tanto temporal como permanente. En todos los Sistemas dentarios la dentición se divide en cuatro hemiarcadas que siguen el siguiente orden: 1 superior derecha, 2 superior izquierda, 3 inferior izquierda y 4 inferior derecha. Los más utilizados son el Sistema Dígito Dos y el Sistema de Zsigmondi.

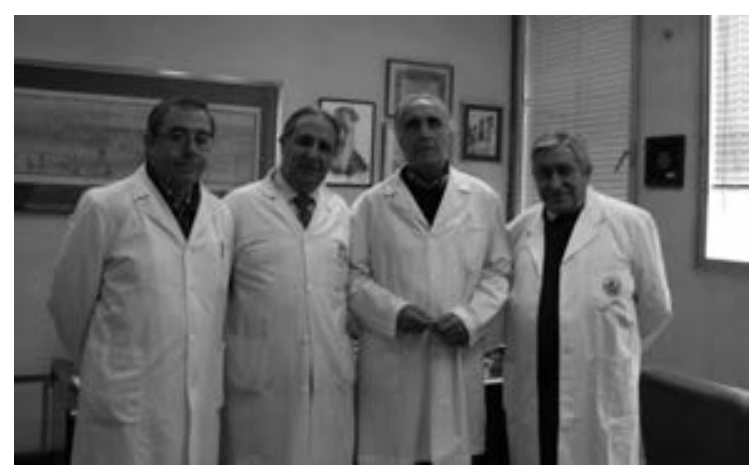

Jaime Whyte, Jesús Obón, René Sarrat, José Luis Nieto 
El Sistema Dígito Dos: recomendado por la Federación Dental Internacional, cada diente es nombrado por dos números correspondiendo el primero a la hemiarcada (12-3-4 para la dentición permanente y 5-6-7-8 para la temporal) y el segundo a la pieza dental contada desde la línea media hacia distal (del 1 al 8 en la dentición permanente y del 1 al 5 en la dentición temporal).

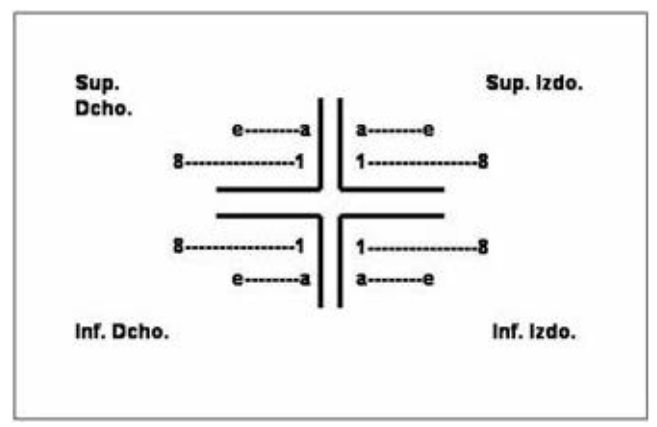

El Sistema de Zsigmondi utiliza números arábigos (1-8) para los dientes permanentes y letras minúsculas (a-e) para los temporales, dentro de un ángulo que representa el cuadrante correspondiente.

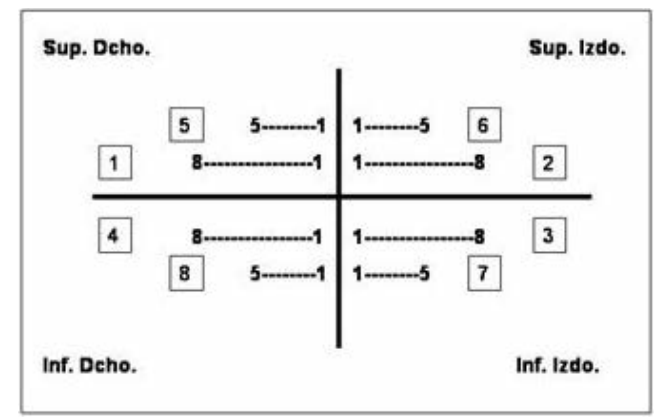

Gracias a su particular resistencia, la dentición está adaptada para soportar, sin alterarse, un gran número de agentes químicos, biológicos y físicos, ante y post-mortem. Debido a sus cualidades: dureza, calcificación, densidad, etc., el diente puede mantener tras la muerte su integridad ante circunstancias que provocarían la descomposición y pérdida de sustancia en otro tipo de tejidos. Todo ello, junto con la capacidad de conservarse fosilizado durante largos períodos de tiempo sin alterarse, hace que la dentición constituya un material de estudio valiosísimo de las poblaciones pasadas y presentes. 
El estudio de los dientes y sus diferentes parámetros ha sido fundamental para la antropología y la paleoantropología por sus especiales características. La primera ventaja del material dental y esquelético sobre los tejidos de otras zonas anatómicas es su capacidad de preservación, aunque hay otras muchas ventajas que lo habilitan como un registro óptimo para el estudio taxonómico.

El hecho de no estar recubiertos por tejidos blandos hace que tenga una mayor accesibilidad y puede medirse tanto en seres vivos como en restos fósiles con métodos similares, además implica un desgaste directo que habremos de tener en cuenta.

Tras su formación, el diente no cambia ni de forma ni en su composición a diferencia de otros tejidos duros como el hueso (turn-over, remodelación). Los cambios en el diente son leves y lentos lo que implica un registro ontogénico prácticamente inamovible por la estabilidad de sus caracteres.

La proporción o tasa de hereditabilidad de los caracteres dentales es mayor que para otros caracteres corporales del individuo. Esta propiedad, de una determinación genética dominante, es importante para la taxonomía, aunque por otro lado no es completa (el polimorfismo bioquímico de los dientes y la influencia de los factores medioambientales impide la interpretación taxonómica categórica mediante la genética-herencia).

El estudio del sexo a través de los dientes presenta mayores dificultades que el estudio de otros parámetros o que el estudio del sexo a través de los huesos. Los dientes humanos son evolutivamente monomórficos; aun así, las escasas diferencias entre sexos sirven como apoyo en el método de identificación del individuo.

El sexo presenta, eso sí, implicaciones en la edad biológica del individuo (tasas de osificación, mineralización, desarrollo y crecimiento) ya que la función endocrina ejerce un probado control biológico desde el desarrollo intrauterino hasta el final de la pubertad y la adquisición de los caracteres adultos. Así pues, la determinación del sexo a través de los dientes es más factible en individuos no maduros. Las coronas dentales, una vez desarrolladas, permanecen invariables excepto que se den diversas circunstancias productoras de cambios (funcionales, intencionales, patológicas, nutricionales, etc.). En la dentición permanente, los diámetros coronarios (de la corona dental) y los caracteres no-métricos son los parámetros más utilizados para la determinación del sexo del individuo.

El desarrollo dentario es considerado como un marcador importante tanto de la edad dental, como del crecimiento general del individuo. Históricamente, la primera vez que se utilizó la erupción dental como medida de madurez fue en 1837 por Saunders. En los últimos años, al estudio comparativo dental tanto anatómico como antropológico (de visu, radiológico, microscópico, bioquímico, etc.) se suma la posibilidad de estudio de las líneas incrementales de los tejidos del diente como medida de crecimiento en los homínidos.

Tanto el estudio del tamaño y del volumen dental, como de los caracteres dentales anatómicos, pueden ser utilizados para hacer una estimación bastante fiable de la raza del individuo. A través de los dientes podemos diferenciar varios grandes grupos racia- 
les: el grupo caucasoide, el grupo negroide y el grupo mongoloide entre otros con unas características o complejos raciales que los diferencian, así, en los caucasoides es más frecuente la presencia de Tubérculo de Carabelli en el primer molar superior permanente, rasgo que es muy poco frecuente en los negroides aunque la frecuencia de aparición va aumentando. En los mongoloides el rasgo más característico es el diente en pala y el taurodontismo.

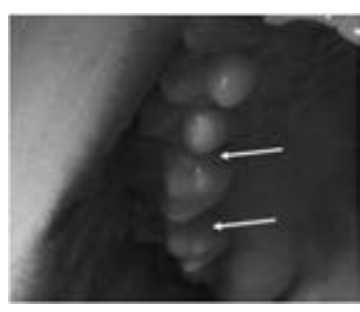

Tubérculo de Carabelli en piezas 16 y 17

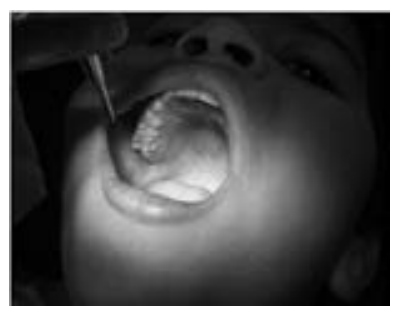

Tubérculo de Carabelli en sujeto de color

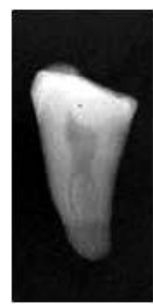

Taurodontismo

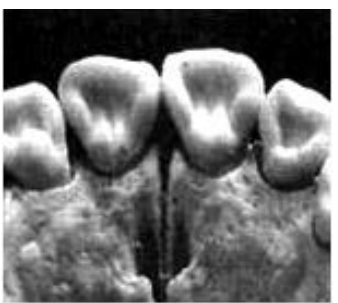

Dientes en Pala

Así pues, el estudio de los caracteres dentales tanto métricos como no-métricos es de gran utilidad para el estudio del sexo, la edad, la raza, los estudios taxonómicos, los estudios familiares, estudios evolutivos y ontogenéticos, etc., como complemento a los estudios métricos y no-métricos craneales y esqueléticos.

Con todo esto, podemos decir que la antropología dental trata del estudio de la variación morfológica y métrica de la dentición de las poblaciones humanas, en el tiempo y en el espacio, y su relación con los procesos adaptativos y los cambios en la alimentación que condujeron a la evolución del hombre. Actualmente con los estudios de la microestriación dental podemos aproximarnos a la dieta que consumió el individuo en vida, así, se puede determinar que una dieta exclusiva vegetariana produce unas microestriaciones finas, abundantes y horizontales, mientras que una alimentación preferentemente carnívora produce microestriaciones profundas, escasas y verticales. En los omnívoros las microestriaciones son una mezcla de horizontales finas y abundantes con verticales profundas y escasas.

Como se ha mencionado anteriormente, las especiales características de la cavidad bucal y las estructuras que la componen la hacen ideal para la identificación cuando el resto de los signos identificatorios biológicos se han perdido o están muy deteriorados, tal es el caso de grandes desastres en masa, incendios, accidentes en medios de transportes, grandes explosiones, ya que el diente es una cavidad estanco para el tejido pulpar, del cual podemos obtener muestras para realizar determinaciones de ADN. Con toda razón la boca ha sido denominada como «la caja negra del organismo». 
En este sentido la odontoestomatología forense, para algunos autores rama de la odontología legal, tiene como objetivo primordial resolver determinados problemas judiciales mediante el aporte de los conocimientos odontológicos y estomatológicos, tanto de cadáveres como de sujetos vivos, ya sean estos, víctimas o agresores.

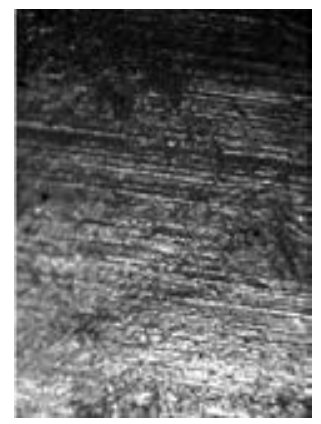

Microestriación en herbívoro

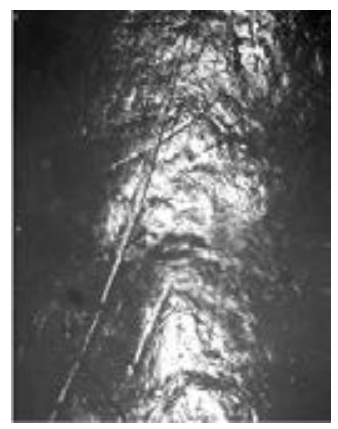

Microestriación en carnívoro

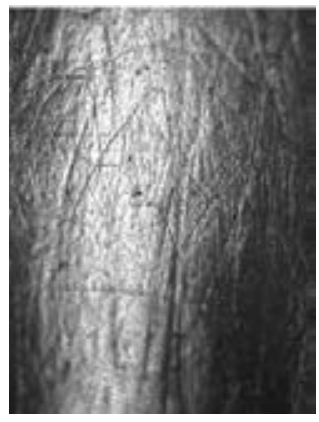

Microestriación en omnívoro

La identificación a través de las marcas de mordida está basada en la individualidad de la dentición humana. La forma de la arcada, el tamaño de los dientes o características de su forma y alineamiento nos permiten identificar con éxito al agresor. Marcas de mordida pueden encontrarse en la piel, de la víctima o del agresor, en restos de comida o en otros objetos. Circunstancias como la elasticidad de los tejidos, la localización, la profundidad, la duración de presión, la succión, la posición o los movimientos de la víctima o si la mordedura se produjo antemortem o postmortem, son parámetros que pueden distorsionar la marca de mordida y que deberán tenerse en cuenta a la hora de realizar su posterior análisis. Las técnicas utilizadas para registrar y analizar las marcas de mordida han mejorado mucho en los últimos años, desde los registros de los arcos dentarios con impresiones de elastómeros y posterior vaciado en escayola, a las técnicas de transiluminación o hasta las basadas en la informática.

Con mi más sincero agradecimiento queda este modesto recuerdo, sabiendo que en todo momento podrá contar mi correspondencia.

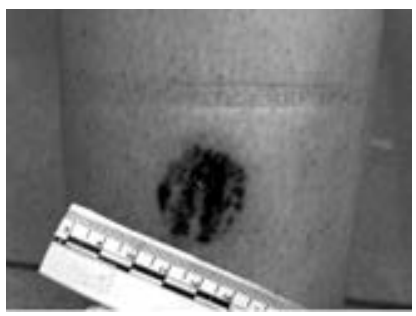




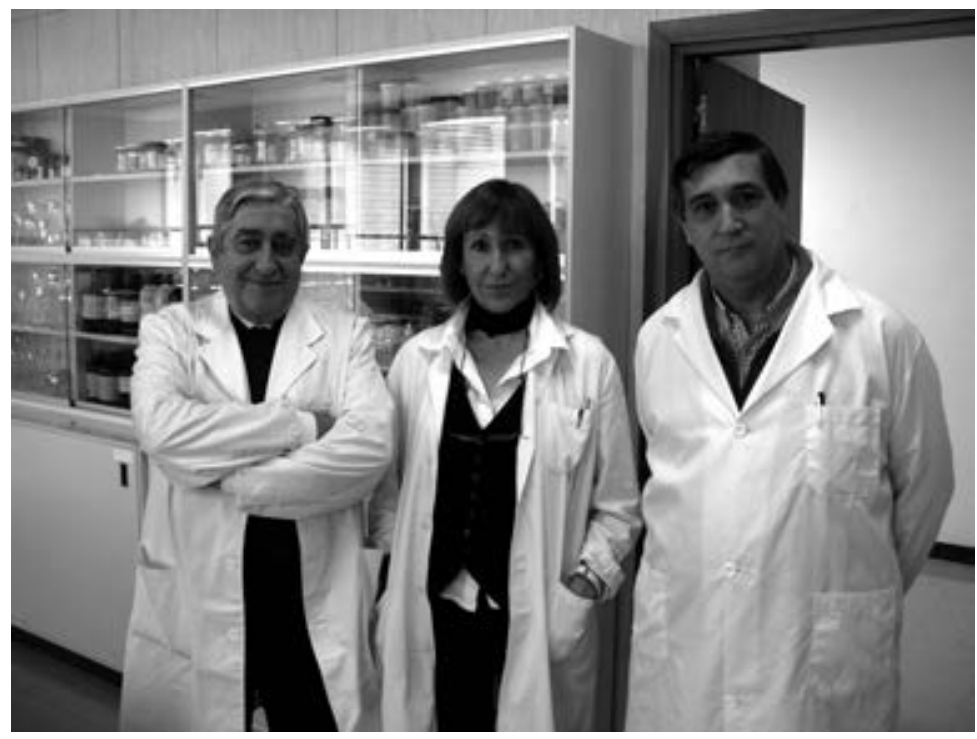




\section{AL PROFESOR RENÉ SARRAT}

\section{Pedro Betrián}

Médico Adjunto. Cardiología Pediátrica

Hospital Valle de Hebrón de Barcelona

Me encuentro hoy aquí sentado frente al papel, con una misión difícil, que no sé si podré lograr. Mi misión es la de poder trasmitir todo aquello que usted supuso para mí, y para muchos como yo. Hace ya mucho tiempo, cuando todavía el blanco no asomaba a mi sien, yo era uno de aquellos más de trescientos jóvenes que un día nos decidimos a iniciar los estudios de medicina en la facultad de Zaragoza. Hace ya realmente mucho, pero aún recuerdo con claridad, nombres, personas, amigos, aquellos que vinieron por vocación, aquellos que no, aquellos días en los que comienza tu vida adulta, pero sigues siendo todavía niño, que se maravilla cuando por primera vez sus pies pisan el suelo de la facultad.

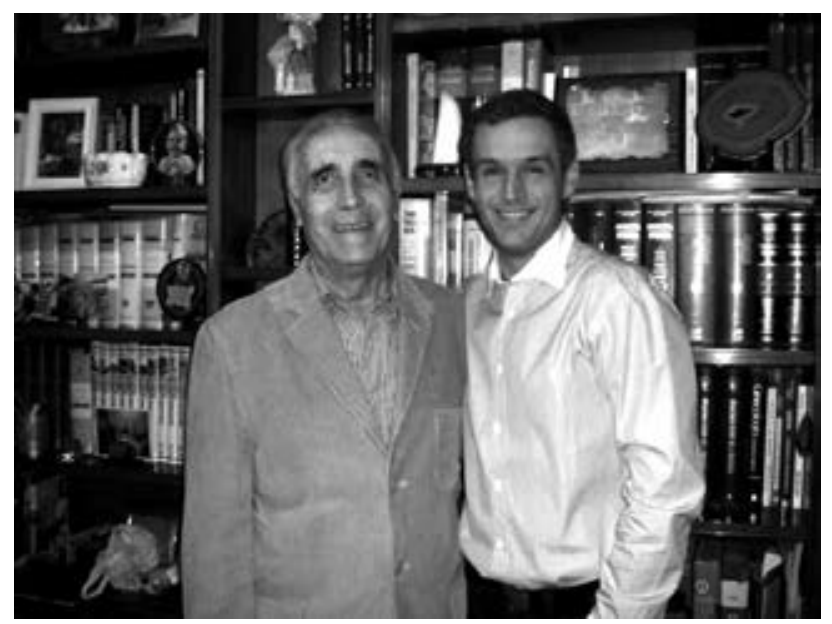

René junto a Pedro Betrián 
Entre esos recuerdos brilla el de esa primera clase, magistral, como todas las que vinieron después, aquella clase en la que vimos pasión en los ojos de la persona que estaba enfrente de nosotros, ese brillo del que sabe y se muere por compartir su saber con los demás, y además disfruta haciéndolo. Nadie pudo permanecer insensible ni impasible ante ese huracán de ideas, de sentimientos, de dudas y de ilusión, que era capaz de inducirnos en sus clases. Recuerdo cómo muchos nos planteamos en esos primeros años que queríamos ser «como usted», y nos preguntábamos qué había que hacer para ser «anatomista».

Nadie, en los años posteriores, ha podido despertar en mí ese interés, esa pasión, que usted lograba transmitir en sus clases, esa mezcla justa de docencia, de arte, de humor, que te hacía «engancharte» a sus clases, que te hacía amar la anatomía por encima de todo, que te hacía querer ser «jefe de mesa» y poder introducirte más todavía en ese mundo, que te hacía aprenderte todos los recovecos del cuerpo humano, con verdadera pasión.

Yo tuve suerte, la varita del azar me rozó, y pude ser jefe de mesa en la sala de disección, pude verle desgranando los secretos que el cuerpo esconde, y aprenderlos de usted, y poder ser yo, el que los transmitiera a mis compañeros. Esa experiencia fue sin duda maravillosa, y me ayudó a comprender el placer que podía llegar a sentirse al compartir, al abrirte, y al enseñar, al ver esas caras sedientas de saber, que siguen tus manos, que escuchan tus palabras, que se alumbran con tus ideas, que te cuentan sus dudas, le entendí un poco más. Desde ese momento, mi relación con la enseñanza no ha pasado de meros escarceos, pero en esos dos años, soy consciente de que el aguijón de la docencia clavó en mí su veneno, veneno que todavía corre hoy por mis venas.

Es quizás ahora, con la edad, y con más experiencia que me doy cuenta de todo lo que de bueno me llevé de esas clases, mucha anatomía, y sobre todo, la conciencia de que todos debemos de dar todo en nuestro trabajo, debemos implicarnos, y si somos afortunados, como lo ha sido usted, amarlo, transmitir todo a los demás, como usted lo ha hecho con tantos y tantos como yo.

Hoy, ya en la lejanía, me arrepiento de no haber saboreado más aquellos dos años, que pude compartir con usted, porque usted hizo de la excepcionalidad hábito, y tan fácil fue habituarse, que llegamos a pensar, que la excepción era norma, y como tantas otras cosas en esta vida, le otorgamos su valor, cuando el devenir del tiempo nos lleva a perderla.

Ahora, que abandona la docencia, siento una profunda pena, por todos aquellos alumnos que ya no podrán disfrutar como yo lo hice, porque yo aprendí entre risas, gracias con las que nos enganchaba, nos daba tregua para poder seguir luego sumergiéndonos en las profundidades del cuerpo, a través de los miles de dibujos con los que fue decorando nuestra vieja pizarra, y en los que surcábamos como marineros de un barco, las inmensidades del cuerpo humano. Viajes y más viajes, a todos los lugares del ser, los visibles y los recónditos, todos los conocimos, por usted y con usted, capitán de esa nave, de la nave del saber, en la que nosotros, pequeños grumetes, éramos todavía, aprendices del aprender. 
Me siento afortunado, porque he sido yo el elegido, para darle las gracias, en nombre de todos, de todos mis compañeros, de los que vinieron delante, de los que han venido detrás. Todos le debemos mucho, y aquí, en estas palabras, quiero transmitirle nuestro agradecimiento, y nuestro reconocimiento, porque sabemos que, gracias a haber compartido con usted esos momentos, hoy, somos mejores.

La vida da muchas vueltas, y en una de ellas Rebeca se coló en mi corazón, y fue ocupando cada vez más, hasta que ya hoy, lo llena con su amor día a día, y es lo más importante de mi vida. Con estas vueltas he pasado de llamarte doctor Sarrat, a llamarte René, a verte como algo cercano, a disfrutar de tu presencia, pero en todo este tiempo, aunque he mirado atrás y he recordado con cariño aquellos días, no he encontrado el momento o la forma de agradecértelo como tú te lo merecías. Así, te doy las gracias René, en nombre de todos, por todo lo que nos has dado a muchos en este tiempo, y te las doy también, en mi propio nombre, por todo lo que a mí me has dado y todo lo que para mí has supuesto en este tiempo.

Desde aquí te quiero decir René, que no sientas ni duda ni temor, en esta nueva etapa que se avecina, porque todos los que te queremos, te vamos a acompañar, unos quizás más cerca, otros separados por insignificantes trozos de tierra, que nunca podrán hacerte sentirnos lejos, pero todos al final, a tu lado, de la misma mano que tanto ha acariciado y compartido, haciéndote sentir especial, como siempre lo has sido, y como siempre nos lo hiciste sentir. 


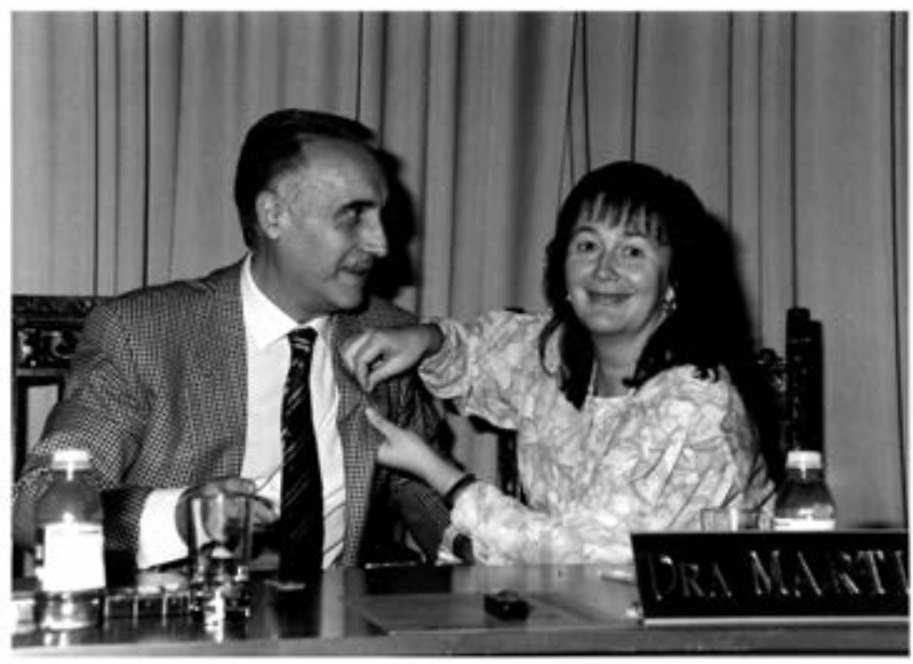




\section{RENÉ SARRAT}

MANUEL LAHOZ

Profesor Titular de Anatomía y Embriología

Facultad de Medicina. Universidad de Zaragoza

Secretario del Departamento de Anatomía e Histología Humanas

Mi relación con el profesor Sarrat comienza en junio de 1983, cuando formó parte del tribunal de las oposiciones a Profesor Adjunto a las que yo me presentaba. Entonces yo no lo conocía pero desde el primer momento me di cuenta de su caballerosidad y calidad humana por el respeto y la forma de tratarnos a unos opositores jóvenes e inexpertos cuando él ya era una persona de reconocido prestigio.

Más adelante me alegré al saber que se trasladaba a Zaragoza.

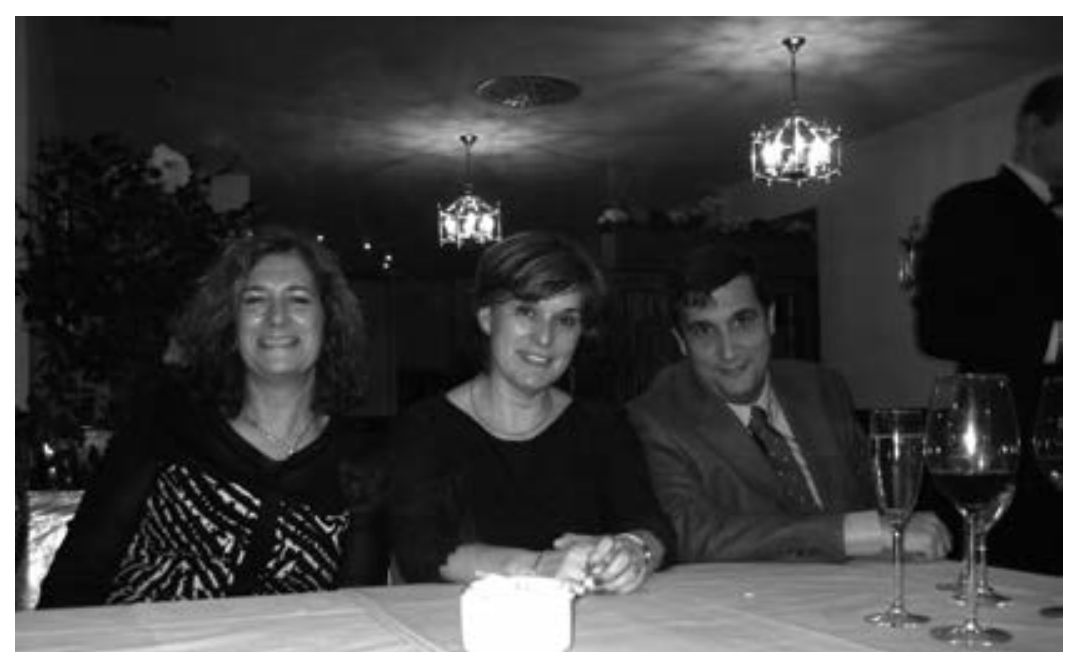

Carlota Castillo, Nieves Pes y Manuel Lahoz 
Desde entonces no puedo decir más que lo que dirán todos los que lo han conocido, porque supongo que todos coincidiremos en los mismos calificativos: una persona siempre cordial, que siempre tiene una palabra de ánimo para cada uno, y siempre dispuesto a hacerte un favor y a facilitar cualquier asunto que se le expusiese.

En cuanto a sus clases ha sido una delicia escucharle. Como nunca se ha negado a nada, hemos aprovechado durante años para pedirle que nos diese el tema de la Anatomía Radiológica que nos tocaba en la parte de la Anatomía que nos correspondiese ese año. De esta manera, me pude dar cuenta cómo es posible compaginar la amenidad con el máximo rigor y cómo puede parecer fácil algo complejo sin perder la profundidad de la explicación.

Por mi parte, solo puedo aportar estas pocas líneas a un merecido homenaje por la jubilación del profesor Sarrat, naturalmente sin que suenen a despedida porque espero que haya múltiples excusas para seguir viéndole.

Felicidades más que por la jubilación por los fructíferos años de trabajo que has realizado y gracias por todo lo que nos has aportado personal y académicamente.

Un fuerte abrazo. 


\section{AL PROFESOR SARRAT}

M. a José LUESMA BARTOLOMÉ

Profesora Ayudante de Anatomía e Histología Ocular en Óptica y Optometría

Facultad de Ciencias. Universidad de Zaragoza el afecto.

Ya pueden hablar de la fama y del honor. Nada de eso vale si se compara con

Ch. Darwin

Recurro a Darwin para apoyarme en su sabiduría porque ante la pugna personal de colarme entre estas páginas, quizá sin ser merecedora de ello, ha vencido estar presente desde la humildad, para mostrar mi gratitud, mi reconocimiento por estos años que hemos compartido, casi un tercio de mi propia vida.

Hace más de una década que me incorporé al Departamento de Anatomía e Histología Humanas en calidad de personal de apoyo a labores de docencia e investigación; el profesor Réne Sarrat enseguida me hizo sentir parte integrante de esta gran familia que conducía desde un liderazgo humanista.

Acababa de terminar mi licenciatura en Veterinaria, arrastraba ilusión, conocimiento, inexperiencia y una gran curiosidad. Tuve la suerte de encontrarme con el profesor Sarrat, doctor en Medicina y en Veterinaria, quien desde el principio me llamaba «compañerita» y esto me daba seguridad, me hacía sentir importante en su equipo. Con esta actitud me integró en un reconocimiento profesional a pesar de mi aparente ingerencia en las áreas de medicina. El profesor Sarrat reunía el saber relacional que yo admiraba y perseguía.

Desde sus habilidades directivas, siempre con su diálogo particular y amable, ha ostentado su liderazgo desde el cariño. Ha fomentado el crecimiento personal y profesional de alumnos, colaboradores, ayudantes, colegas y todo aquel que estuviera a su lado, sin descuidar jamás la exigencia del profesor consciente de motivar hasta conseguir aquello que de nosotros esperaba.

Además del apoyo en la organización de mi labor y responsabilidad cotidiana, me brindó la oportunidad de realizar la tesis doctoral, de la que fue mi codirector junto a la doctora Torres y al doctor Whyte. Aún sin ser su discípula directa he bebido de sus fuentes como alumna de tercer ciclo, colándome incluso como «oyente oportunista» 
para descubrir la magia que era capaz de crear en el aula. Pude corroborar la fama que le precedía de creador de fascinación, capaz de mantener la atención del alumnado o del auditorio con una maestría propia de los grandes oradores. Humanista, seguidor de los grandes genios, propio del Renacimiento, culto, polivalente, interdisciplinar, ha conseguido que la Anatomía transcendiera a cualquier ámbito de la vida, incluido el humor.

Ante esta nueva aventura docente en la que me embarco me siento un tanto huérfana, un poco entristecida por no poder abordarle con mis incansables interrogatorios que amablemente atendía. Ahora como docente reconozco mejor su claridad, su transparencia en la comunicación, el esfuerzo y la dedicación de hacer fluir conocimientos. El profesor Sarrat conoce bien la diferencia entre el reconocimiento y la gratitud, por eso, y aunque aún nos quedan muchas tazas de té matutinas que compartir, GRACIAS querido «jefe», muchas gracias.

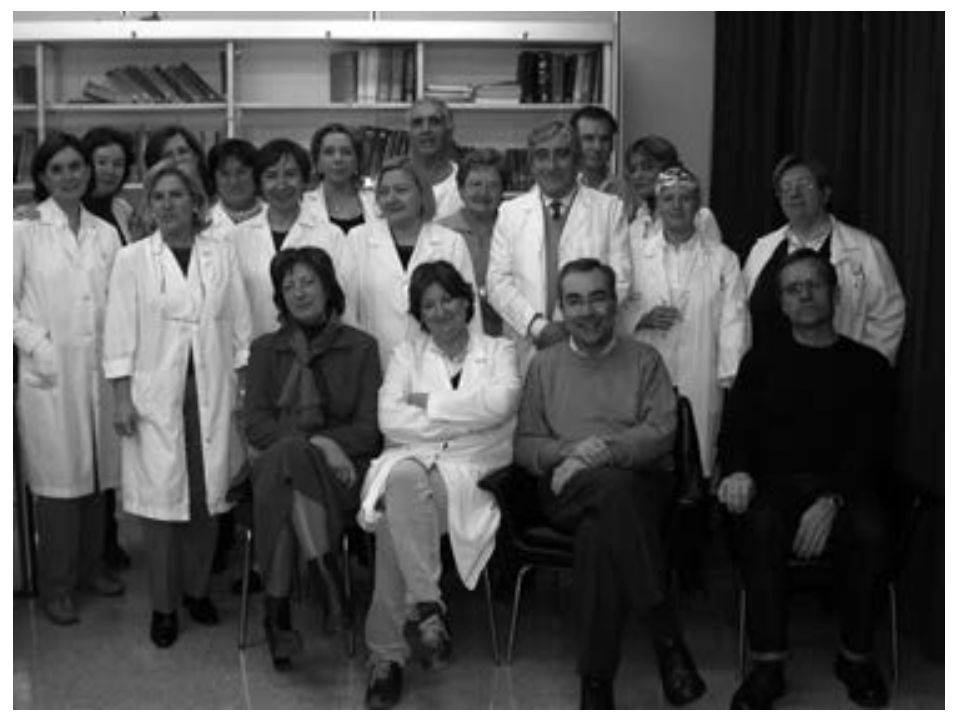

Miembros del Departamento de Anatomía e Histología Humanas de la Universidad de Zaragoza 


\title{
CORRELACIÓN RADIOLÓGICO-PATOLÓGICA: UN NUEVO ENFOQUE DEL DIAGNÓSTICO POR IMAGEN
}

\author{
LUIS Humberto Ros MENDOZA
}

Jefe Unidad de Radiodiagnóstico. Hospital General Royo Villanova

Académico Correspondiente de la Real Academia de Medicina de Zaragoza

\section{Introducción}

Aun siendo radiólogo (eso sí, de una de las mejores escuelas del país, la del profesor Fernando Solsona), he tenido el privilegio de participar en la labor docente del Departamento de Ciencias Morfológicas de nuestra querida Facultad de Medicina.

Poco tiempo después de mi vuelta de Estados Unidos, donde estuve durante un curso académico (1991-1992) dedicado al aprendizaje de las bases físicas y técnicas de la resonancia magnética, un grupo de entusiastas profesores del Departamento de Anatomía que dirigía el profesor René Sarrat, animados por las posibilidades docentes que las imágenes de esta nueva modalidad diagnóstica ofrecían, me propuso complementar las clases teóricas con imágenes de resonancia. Lo que comenzó de un modo amateur siendo algo un tanto improvisado, con el paso del tiempo se profesionalizó, englobando imágenes de las distintas técnicas radiológicas: ultrasonidos, tomografía axial computarizada, estudios angiográficos, radiología convencional y cómo no: resonancia magnética.

Nació así una entrañable relación con el Departamento de Ciencias Morfológicas, muy fructífera y útil para mí desde el punto de vista académico y, sobre todo personal, puesto que además de proporcionarme muy buenos amigos, me permitió también comprender de manera clara lo que podríamos denominar como correlación anatomo-radiológica, imprescindible en nuestra mentalidad, como radiólogos, para entender la patogenia y la fisiopatología de determinados procesos, aclarando o explicando los hallazgos de imagen en las distintas entidades patológicas.

El concepto clásico de correlación clínico-radiológica, la valoración de los síntomas como justificación o explicación de los hallazgos radiológicos, es algo que ya teníamos asumido desde nuestros tiempos de estudiantes y ulteriormente en nuestra etapa de for- 
mación especializada. Finalmente el ciclo se cierra con otra correlación, no menos importante e interesante: la correlación radiológico-patológica, consistente en la confrontación de los hallazgos anatomopatológicos y los de las distintas técnicas de formación de imagen.

Es este último un concepto acuñado en el Instituto de Patología de las Fuerzas Armadas de Washington, centro pionero donde me desplacé en el curso de mi etapa como research fellow en el Departamento de Radiología de la Universidad de Florida para aprenderlo.

Véanse estas líneas que siguen a continuación como un pequeño homenaje, un testimonio, de admiración, respeto y cariño a la figura del profesor René Sarrat.

A él, maestro de la correlación anatómica, los radiólogos le ofrecemos uno de los instrumentos más útiles de los que, hoy en día, disponemos para llevar a cabo nuestra labor y efectuar nuestros diagnósticos.

\section{Concepto de correlación radiológico-patológica}

El análisis de los numerosos métodos de investigación semiológica, a la búsqueda del diagnóstico de las enfermedades, muestra cómo, en síntesis, uno de sus objetivos fundamentales ha sido siempre la visualización de la lesión orgánica. En este sentido la historia de estos métodos ha consistido en una progresiva «revelación», pasando a través de la «opacidad» del cuerpo humano.

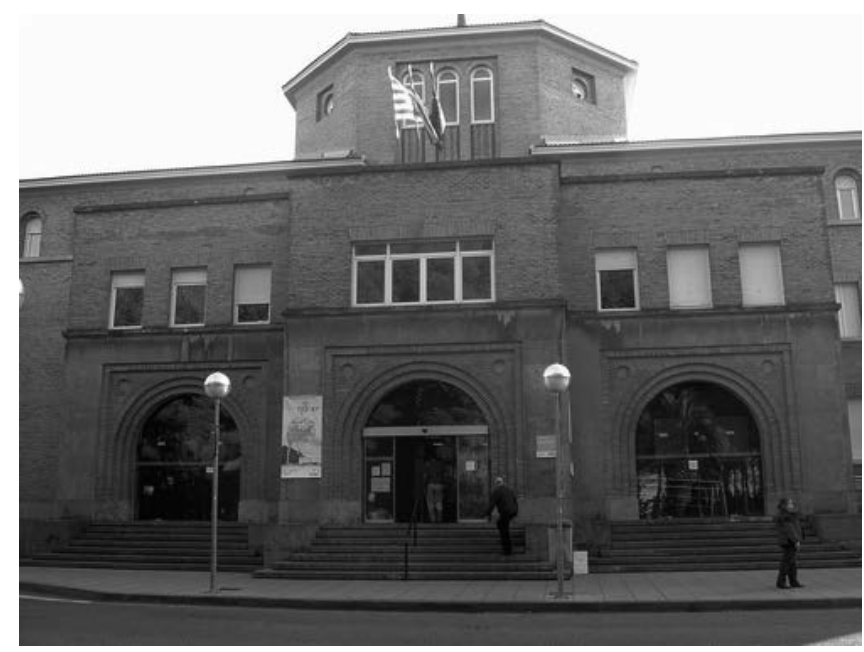

Hospital Royo Villanova de Zaragoza 
La primitiva semiología que el médico obtenía en la superficie corporal con su tacto y con su mirada, y más tarde escuchando a su través, fue enriquecida por el método anatomoclínico, que permitió, mediante la visualización de la lesión orgánica en el curso de la autopsia, correlacionar el «síntoma» con el hecho patológico y convertirlo en «signo» de una determinada enfermedad. Más allá de la mirada que observa las lesiones en el cadáver (necropsia), la cirugía, al conseguir penetrar en las cavidades orgánicas y concretamente en la abdominal, permite la observación in vivo de estas lesiones e incluso su tipificación mediante biopsia, exteriorizando a la medicina interna. Hoy en día este concepto puede lograrse de un modo incruento merced a las distintas técnicas de formación de imagen utilizadas en radiología.

Es, pues, imprescindible un lenguaje compartido entre el clínico y el radiólogo, que facilite el enfoque multidisciplinar de las distintas entidades nosológicas, con algoritmos* que aunen no solo la eficacia e inocuidad sino también el bajo costo.

El afán primordial de la radiología diagnóstica ha sido siempre el incrementar las pequeñas diferencias de densidad de las distintas estructuras orgánicas, para poder distinguir tejidos o entidades entre sí. Toda la historia del radiodiagnóstico es la de la lucha por hacer patentes estas diferencias.

La introducción de los rayos X en la clínica supuso el inicio de un nuevo camino, mediante el cual la revelación, la transparencia del velo opaco corporal, se podía conseguir sin solución de continuidad, en un juego de luces y sombras.

La utilización de sustancias de contraste en las técnicas radiológicas, la ultrasonografía, la tomografía axial computarizada (TAC) y la resonancia magnética (RM) han permitido la «penetración» de la mirada del médico hasta límites insospechados, por su profundidad y precisión.

Estas técnicas constituyen lo que en conjunto se conoce como «nueva imagen»o «nueva frontera de la radiología», posibilitando una adecuada valoración de la anatomía macroscópica y de la patología de las distintas estructuras de la economía.

Estas técnicas seccionales posibilitan la visualización del interior de las vísceras sólidas, antaño no accesibles a los métodos de radiología convencional.

Pero si siempre ha sido fundamental la correlación clínico-radiológica, en cuanto que el enfoque clásico del diagnóstico por imagen reside en la posibilidad de aplicar de un modo secuencial las distintas técnicas que el radiólogo tiene a su disposición para aclarar el problema clínico, siendo este el que guía en inicio la utilización de uno u otro de los algoritmos de diagnóstico por imagen; hoy en día también se considera con plena vigencia el concepto de correlación radiológico-patológica, mediante la que se comparan los hallazgos de las distintas técnicas de imagen con los hallazgos anatomopatológicos subyacentes, tanto en la vertiente macro como microscópica. Este enfoque es sumamente interesante y útil, en cuanto que el conocimiento de los hallazgos y características anatomopatológicas posibilita la comprensión de los hallazgos radiológicos y ayuda al especialista en diagnóstico por ima- 
gen en la evaluación de las distintas entidades nosológicas, enfatizando los hallazgos clave que resultan más útiles para estrechar las opciones de diagnóstico diferencial.

En este enfoque cada entidad se presenta con una definición y un resumen de los hallazgos clave macro y microscópicos que determinan sus características y apariencia radiológica. En conjunto, el reconocimiento y la comprensión del espectro de los hallazgos radiológicos y anatomopatológicos facilita el diagnóstico diferencial de las distintas patologías.

Es este un enfoque en el que el Instituto de Patología de las Fuerzas Armadas de Washington (Armed Forces Institute of Pathology: AFIP) ha sido pionero en el mundo, creando escuela ulteriormente en los Institutos de Radiología más renombrados y creando también un cuerpo de doctrina con plena y actual vigencia desde el punto de vista no solo asistencial sino también docente e investigador.

Este Instituto fue fundado en 1862 a raíz de la guerra de secesión entre los estados del norte y del sur, como Museo Médico del Ejército de los Estados Unidos (Army Medical Museum), para albergar el material médico bélico acumulado por el cuerpo médico del ejército americano. Con el tiempo se convirtió en un centro de referencia y consulta, fundamentalmente anatomopatológico, abierto a todo el mundo y dio cabida también a los cuerpos médicos de la armada y fuerza aérea americana (de ahí el termino Instituto de Patología de las Fuerzas Armadas).

Actualmente los archivos del AFIP constan de más de cuatro millones de casos, todos ellos, por definición, probados histológicamente.

En 1947, y debido a que algunos casos, principalmente de patología ósea y pulmonar, se consultaban además de con el material anatomopatológico con radiografías simples, se abrió dentro del AFIP el departamento de patología radiológica. En este departamento especialistas en radiología trabajan conjuntamente con los de anatomía patológica enfocándose su actividad en la investigación y la educación radiológicopatológica. Cuentan para ello con los archivos que engloban los casos problema remitidos por los diferentes hospitales del mundo y que poseen además del material anatomopatológico, imágenes radiológicas.

*Algoritmo: término con el que se indica cualquier procedimiento sistemático de cálculo con el que se halla el resultado deseado mediante una sucesión bien determinada de operaciones realizables según reglas precisas.

En la Edad Media el término algoritmo significó tan solo la ejecución de las «cuatro operaciones» mediante las cifras árabes y las reglas de cálculo conocidas con el sistema de numeración decimal posicional; los seguidores del nuevo método fueron llamados «algoritmistas», en contraposición de los «abaquistas», que siguieron calculando con el ábaco. Los algoritmistas seguían las reglas expuestas en un libro del matemático árabe Mohamed ibn Musa al-Khuwarizmi, que trabajó en Bagdad alrededor del año 830 de nuestra era; este libro se conocía en la Edad Media como el Liber Algorismi, y de aquí «algoritmo», deformidad del nombre del autor. 


\section{Criterios generales}

Globalmente, la metódica de trabajo que se sigue mediante este enfoque implica la evaluación conjunta de los hallazgos radiológicos y anatomopatológicos de una entidad definida.

En una aproximación inicial se revisa la historia clínica y los datos referentes a sexo, edad y antecedentes de cada caso, para ulteriormente valorar los criterios semiológicos tanto radiológicos como anatomopatológicos de cada entidad.

De un modo genérico se valoran, desde el punto de vista radiológico, los siguientes criterios de cada entidad: tamaño de la lesión, localización, características morfológicas, estructura interna, carácter sólido o quístico, posible presencia de calcificaciones, grado de intensificación postcontraste (TAC y RM), así como las características propias que pudiera presentar cada variante. Ulteriormente se revisan los hallazgos anatomopatológicos intentando establecer una correlación que ayude a explicar los criterios semiológicos radiológicos previamente evaluados. En el caso de las enfermedades difusas el abordaje es similar, valorando la morfología visceral, las características de la ecoestructura, valor de atenuación o intensidad de señal del parénquima, tipo de realce postcontraste del mismo y características de la circulación parenquimatosa.

En conjunto, pues, el material se revisa retrospectivamente, tabulando por separado los hallazgos radiológicos y anatomopatológicos y llevando a cabo una comparación detallada de los mismos, evaluando finalmente los resultados por un equipo constituido por los dos tipos de especialistas, radiólogos y patólogos.

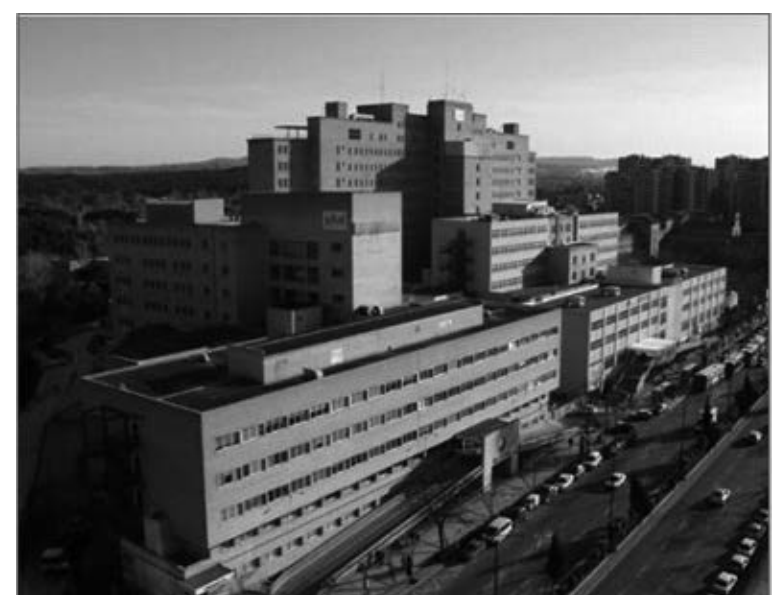

Hospital Clínico Universitario Miguel Servet de Zaragoza 
Este abordaje permite establecer no solo criterios de correlación radiológico-patológica sino que es útil para definir los criterios más específicos de cada entidad en las distintas modalidades de formación de imagen (ecografía, TAC, RM), sentando así las bases para su identificación mediante las distintas técnicas radiológicas, lo que repercute ulteriormente en un adecuado tratamiento del paciente.

\section{Tendencias futuras}

Si este concepto de correlación radiológico-patológica es un abordaje útil hoy en día, en un futuro inmediato las opciones diagnósticas desde el punto de vista de las técnicas de formación de imagen van a estar basadas en el concepto de imagen funcional a nivel molecular, cuya representación actual está constituida por la moderna tomografía por emisión de positrones, merced a la cual se detectan alteraciones funcionales de las distintas estructuras de la economía en una etapa previa a su representación morfológica.

Son técnicas que requieren la cooperación de dos especialistas, en cuanto que se auna la alteración funcional, evaluada mediante técnicas de medicina nuclear, con la localización topográfica de la misma por parte del especialista en radiodiagnóstico (PETTAC, técnica híbrida que supone la frontera más avanzada del diagnóstico por imagen en la actualidad).

¿Dónde quedará el concepto de correlación anatomo-radiológica o el de correlación radiológico-patológica ante esta evolución de la tecnología? No podemos saberlo, pero lo cierto es que esos conceptos, hoy ya clásicos, han sido y son todavía muy útiles y gracias a ellos se ha recorrido un camino, tremendamente atractivo, que ha posibilitado que hoy en día estemos ante este reto que constituye la imagen funcional, la imagen molecular, difícil ya de correlacionar con la anatomía normal o los hallazgos anatomopatológicos.

Futuro interesante que nos conducirá por caminos insospechados. 


\title{
AL PROFESOR RENÉ SARRAT
}

\author{
AnA I. Cisneros Gimeno \\ Profesora Colaboradora de Anatomía y Embriología Humanas \\ Facultad de Medicina. Universidad de Zaragoza \\ JaIme Whyte Orozco \\ Profesor Titular de Anatomía y Embriología Humanas \\ Facultad de Medicina. Universidad de Zaragoza
}

Cuando el director de Departamento nos invitó a participar en este libro-homenaje, tanto Jaime como yo pensamos que al haber sido sus últimos discípulos, y haber convivido ambos estos últimos años, compartiendo las mismas vivencias, deberíamos reflejarlas juntos. Nuestra trayectoria ha sido muy similar, junto al profesor Sarrat aprendimos Anatomía, pero sobre todo nos vimos impregnados por esa humanidad que él destila. Hemos pasado buenos y malos momentos, pero siempre estaba él con sus consejos y su cariño, haciendo que todo fuera más fácil. Generosamente poco a poco sin que nadie se diera cuenta fue dándonos más responsabilidades, tanto docentes, como investigadoras, incluso de gestión. Nos fue preparando para cuando él se retirara a disfrutar de ese tiempo libre que ya le va tocando tener, para poder estar más con su familia y con su tierra.

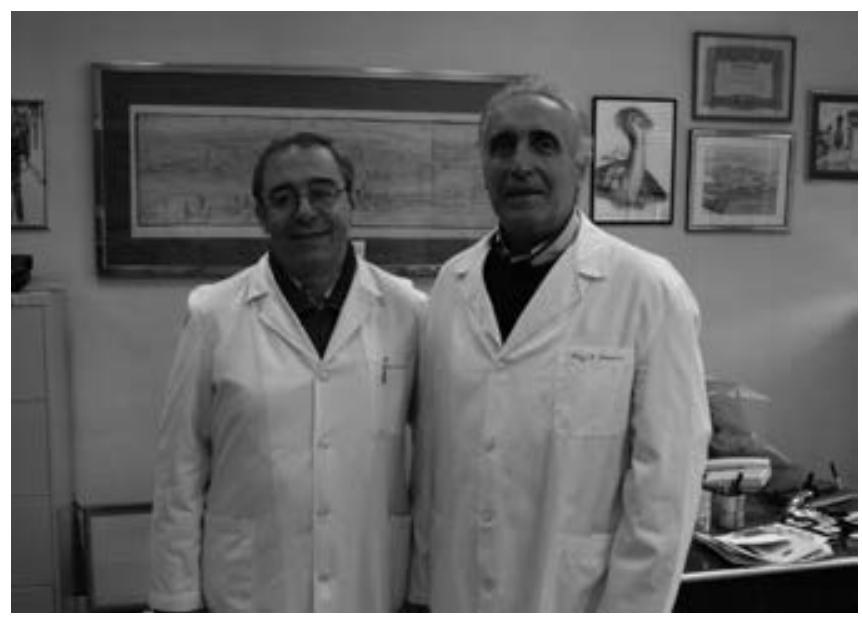

Jaime Whyte y René Sarrat 
Hace 20 años, cuando llegué a la Facultad de Medicina, el primer día de clase nos recibió un profesor ataviado con pijama blanco inmaculado, que nos contó durante un rato que nos iba a explicar la Anatomía, cómo iban a ser las prácticas, los exámenes, etc., cuando terminó su explicación había conseguido que su asignatura, que todos sabíamos que era un hueso duro de roer, no nos parecía tan terrible, y que tuviéramos ganas de empezar enseguida.

Fueron increíbles todas las horas que en el aula pasamos, escuchábamos a un profesor que vivía con intensidad lo que te explicaba, que te contagiaba su entusiasmo, que solo con una tiza y una pizarra hacía surgir dibujos y esquemas como si un atlas de anatomía tuviéramos delante. De sus clases salías con ganas de coger los apuntes y empezar a estudiar, mirábamos libros, trabajábamos en grupos, nos «picábamos» a ver quién sabía más...

Pero lo mejor era estar en la sala de disección. Sacábamos los cadáveres y él enseguida se lanzaba con su bisturí y sus pinzas a mostrarte hasta el más recóndito rincón, hasta el más minúsculo vaso o nervio que se pudiese disecar. Le encantaba que todo el mundo se acercara, nos colocábamos alrededor de él, subidos en silletes, todos apiñados, de puntillas, y siempre decía: «Apoyaros en mí que no me importa, que note que estáis ahí, sobre todo que lo veáis bien». Cuando nos despistábamos, o nos poníamos a hablar, nos chistaba y decía señalando lo que estuviera en ese momento disecando: "¿habéis visto que majico?», y todo esto siempre con su habitual tono cordial y alegre.

Su gran simpatía siempre ha sido uno de sus bastiones, ha sido el profesor que más cercano sentíamos, y sin embargo el que más respeto nos infundía, como decía él: «confianza toda, confianzas ninguna». Un día en una clase de repaso antes de un examen me preguntó: «¿tienes alguna duda?» y yo le dije: «muchas, toda yo soy una duda», se rió y me contestó: «entonces será una duda pequeñita». Años después cuando ya estaba en su grupo pasó a llamarme «chispa», y lo sigo siendo a fecha de hoy.

Sus exámenes orales los he vivido como alumna y como ayudante. Como lo primero los viví con el respeto y el pánico que te genera la situación, miedo que desaparecía cuando oías tu nombre y te recibía el profesor Sarrat con su sonrisa y sus frases cordiales, y salías encantada de la vida; como lo segundo ha sido más divertido porque lo he visto desde la «barrera», y he descubierto cómo a pesar de ser tan encantador, luego es muy exigente con los alumnos.

Fue tras licenciarme cuando me incorporé al grupo de investigación que dirigía el profesor Sarrat, y en el que ya estaba Jaime, para realizar mi tesina de licenciatura, y posteriormente la tesis doctoral, quedándome en el Departamento como becaria primero, y profesora después junto a él.

Por su parte Jaime conoció a don René (como él siempre le llama) habiéndose ya licenciado, cuando empezó a realizar la tesis doctoral bajo su dirección. Durante este tiempo estuvo acudiendo con regularidad a sus clases, ya que como él cuenta le interesaba aprender su forma de explicar la Anatomía. Le cautivó, se dio cuenta de que para ser un buen docente te tiene que importar el alumno, el profesor Sarrat así lo demostraba con sus clases en las que se implicaba al $100 \%$ con los chicos que tenía a su alrededor. 
Tras su periodo como profesor en Huesca, Jaime se trasladó a Zaragoza donde comenzó a trabajar codo con codo con él. Durante estos años siempre se les ha podido ver juntos, yo creo que era casi imposible no localizarlos así, llegando a tener ambos un vínculo afectivo que, más allá de la Universidad, pasó a ser una gran amistad. Jaime, parco en palabras, ha llegado a tener una comunicación tan estrecha con el profesor, que una sola mirada les vale para saber lo que están pensando, tiene tantas vivencias personales con nuestro jefe que me ha pedido que queden entre ellos.

Durante nuestras horas dedicadas a la investigación hemos conocido a una persona con grandes ideas, claridad y visión de futuro, que te conseguía entusiasmar con todo lo que hacía, que cuando las cosas no salían como andabas buscando, tenía siempre una palabra de apoyo. Persona de gran doctrina y sobre todo de muchísima paciencia, nos fue abriendo las puertas a la investigación, fue haciendo que cada vez quisiéramos saber más, nos fuimos enganchando al mundo de los portas, el laboratorio, la bibliografía... siempre contagiados por ese entusiasmo que pone a todo lo que él hace. Generoso donde los haya, siempre hemos podido contar con su ayuda, con su tiempo y con todo lo que él tenía en su despacho. Es persona sabia, paciente, amable y entrañable que siempre ha hecho que cualquier reto, cualquier explicación fuera lo más sencillo del mundo.

Si algo hay que destacar de nuestro «jefe» es su gran humanidad, y sus ganas de superarse. Él siempre usaba la frase de Letamendi que dice: «si un loco se empeñase en apedrear a la luna no alcanzaría naturalmente su objetivo..., pero llegaría a ser un hondero excepcional».

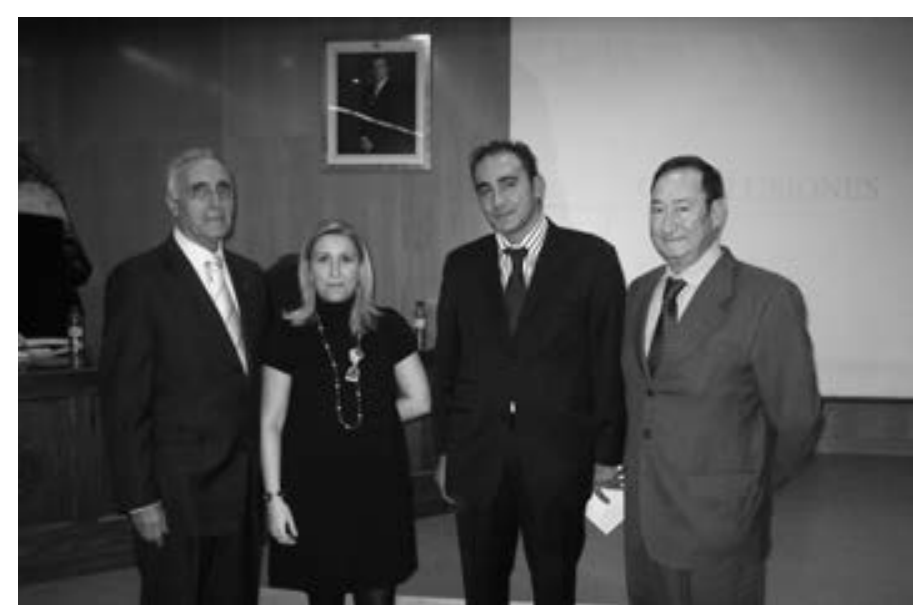

R. Sarrat y Ana Cisneros junto a los doctores Galo Elía (padre e hijo) 
Sirva esta frase como capítulo final de este libro homenaje a nuestro Maestro, por tener el honor ambos de ser sus últimos discípulos. Tanto Jaime como yo queremos que él y su familia sepan que siempre estaremos a su lado, como hemos estado haciendo estos años, en los buenos momentos y los, a veces, no tan buenos.

Por tu cariño y entrega..., igracias, jefe!

Ana Cisneros y Jaime Whyte

P.D. Y un beso, que como siempre dices no hay que perder las buenas costumbres. 


\title{
TESTIMONIO FINAL
}

\author{
Marco ANTONio SARRAT TORRES
}

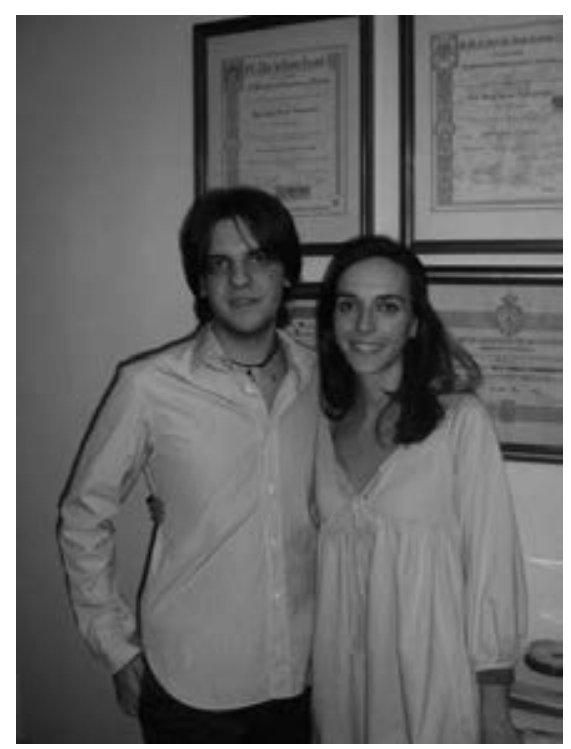

Marco Antonio y Rebeca Sarrat Torres

Siempre me he preguntado por qué he tenido vocación para estudiar Medicina. Supongo que la respuesta era intentar verme reflejado en la persona que más he admirado de toda mi vida: mi padre.

Desde que tengo uso de razón, he admirado esa forma cariñosa que tiene de tratar al enfermo, y que hace que se gane su confianza y respeto para siempre; esa humildad que siempre lleva consigo y que no le permite olvidarse nunca de sus orígenes en la torre de Corbins, cuando ayudaba a mis abuelos en el campo; esa manera de responder a mis preguntas, fuesen de la asignatura que fuesen, con mucho rigor científico unas veces y con mucha imaginación en otras, aunque posteriormente las comprobara en algún libro, y le fuese toda la noche en ello.

Nunca me ha extrañado por eso que todo el que conociera a mi padre, siempre se deshiciera en halagos hacia él, fuera alguien del pueblo o de la facultad, pero sobre todo sus queridos alumnos. Muchas veces pensaba que lo hacían para regalarme los oídos o con afán de ver si así, gozando de mi simpatía, arañaban alguna décima en algún exa- 
men. Hasta que yo mismo fui a una clase suya y pude comprobar lo que era en verdad la docencia. Nada tenía que ver con clases aburridas, interminables en las que lo único que esperas es que el reloj marcara el fin de la hora. Todo lo contrario, cuando la manecilla marcaba el final, te hacía despertar del sueño en el que estabas enfrascado, escuchando las inserciones de los ligamentos, las inervaciones sensitivo-motoras, cobrando todo una función y un sentido que jamás habrías imaginado antes. En esos momentos todos estábamos orgullosos de estar estudiando medicina, salíamos de clase con un aire renovado y lleno de optimismo para afrontar el largo camino que aún nos quedaba por delante.

Obviamente para trasmitir todo estos conocimientos de una manera tan simple y extraordinaria, hay que ser un enamorado del cuerpo humano. Por eso lo que a otros se les puede antojar una utopía y costarles una vida de esfuerzo, a mi padre es algo que siempre le ha salido solo, de forma natural.

Es por ello que esto no es un adiós, es solo un alto en el camino, pues tras haber dedicado una vida entera a la universidad, estoy firmemente convencido que una gran parte de él se quedará en las aulas y en la sala de disección, así como en los corazones de los alumnos que tuvimos el honor de aprender, no solo de sus enseñanzas, sino de su visión humana de la medicina. La universidad no es una fría institución, y lo que la hace especial y le da prestigio son sus mentores, pudiendo decir en mi modesta opinión que también una pequeña parte de ella lleva inscrito el sello del profesor más «Guachi, Guachi».

Siendo espectador de primera fila de la vida de mi padre, por todo lo que nos ha querido y nos quiere, por todo lo que nos ha ayudado a mi hermana y a mí, siempre he estado y estaré muy orgulloso de él, dándole las gracias por ello. Todo lo que mi hermana y yo somos, se lo debemos a nuestros padres, y nos esforzaremos para que el día de mañana podamos ser tan buenos referentes como ellos lo han sido para nosotros. 


\section{ÍNDICE}

Arturo Vera Gil, José L. Nieto Amada: Ofrecimiento ................

Arturo Vera Gil, Carmén Pérez Castejón: Al profesor René Sarrat

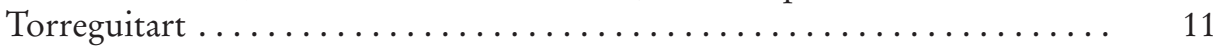

Rafael Mazo Torres, Javier Mazo Torres, Juan José Mazo Torres: Apuntes de una vida ............................... 17

Víctor SMith: Jubilación del profesor René Sarrat Torreguitart .......... 23

RICARDO VÁZQUEZ: René Sarrat Torreguitart, amigo, compañero y Receiving Editor de la revista European Journal of Anatomy .................

José M. ${ }^{a}$ Smith Ágreda, Inés Fernández Ortega: Semblanza de René Sarrat, el hombre, el profesor y el amigo .................... 35

José Luis Bueno López: Al profesor René Sarrat $\ldots \ldots \ldots \ldots \ldots \ldots \ldots \ldots$

Leonor Hennequet Fernández: René Sarrat Torreguitart............. 47

M. ${ }^{a}$ Pilar Díaz Herrera: En recuerdo y agradecimiento al profesor René Sarrat 53

Carmen Cavada: Al profesor René Sarrat .................... 59

Vicente Calatayud Maldonado: La gran lección de René Sarrat........ 65

Juan Antonio Abascal Ruiz: Al profesor René Sarrat ............... 71

Julia Blasco Oquendo: Al profesor René Sarrat ................ 77

CARMEn Martínez: Al profesor Sarrat ...................... 79

M. ${ }^{a}$ Asunción Escolar, Juan de Dios Escolar: Al profesor René Sarrat ... 81

Pedro Cía Gómez: Profesor René Sarrat . . . . . . . . . . . . . . . . 85

Carmen de la Hoz Torres: Homenaje al profesor René Sarrat. ......... 89

José Manuel Gómez Beltrán: Al profesor doctor don René Sarrat Torreguitart en la fecha de su jubileo (70 años de su nacimiento $) \ldots \ldots \ldots \ldots \ldots \ldots \ldots .91$

José Luis Lancho Alonso, María S. Poblador Fernández: Al profesor René Sarrat. . . . . . . . . . . . . . . . . . . . . . . . . 95

SAntiago Rodríguez: Ladrones de cerebros..................... 99

Miguel Ángel CrovetTo de la Torre: Al profesor René Sarrat........ 105 
J. V. LAFUENTE: René, palabra y magisterio......................

José Vicente Lafuente, Enrique G. Argandeña: Desarrollo postnatal de la vascularización del córtex visual $\ldots \ldots \ldots \ldots \ldots \ldots \ldots \ldots \ldots \ldots \ldots \ldots \ldots \ldots \ldots$

Jesús Fernando EsCANERO: Psicodidáctica y neurodidáctica: dos desconocidas de los docentes médicos . . . . . . . . . . . . . . . . . . . . . .

José Luis Nieto Amada: Al profesor René Sarrat: una visión desde otra escuela 125

JuAn Antonio Vecino: Gracias, profesor Sarrat . . . . . . . . . . . . . 131

Jesús Ángel Obón Nogués: Pinceladas sobre odontología . . . . . . . . . . 135

Pedro Betrián: Al profesor René Sarrat ....................... 141

MANUEl LaHoz: René Sarrat . . . . . . . . . . . . . . . . . . . . . . . . . . 145

M. a José Luesma BARTOlomé: Al profesor Sarrat . . . . . . . . . . . . 147

Luis HumberTo Ros MendozA: Correlación radiológico-patológica: un nuevo

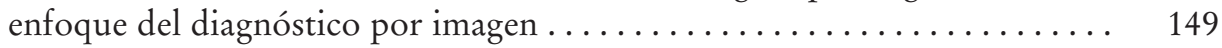

Ana I. Cisneros Gimeno, Jaime Whyte Orozco: Al profesor René Sarrat . . 155

Marco Antonio Sarrat Torres: Testimonio final.................. 159 
ISBN 978-84-92521-91-3

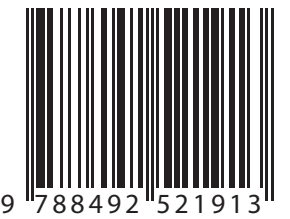

Prensas Universitarias de Zaragoza 